Cosmologias da Violência: entre a regra e a exceção Uma etnografia da desigualdade em São Paulo

Paula Miraglia 
UNIVERSIDADE DE SÃO PAULO

FACULDADE DE FILOSOFIA, LETRAS E CIÊNCIAS HUMANAS

DEPARTAMENTO DE ANTROPOLOGIA SOCIAL

PROGRAMA DE PÓS-GRADUAÇÃO EM ANTROPOLOGIA SOCIAL

\title{
Cosmologias da Violência: entre a regra e a exceção Uma etnografia da desigualdade em São Paulo
}

\author{
Paula Miraglia \\ Tese apresentada ao Programa de \\ Pós-Graduação em Antropologia Social \\ do Departamento de Antropologia Social \\ da Faculdade de Filosofia, Letras e Ciências \\ Humanas da Universidade de São Paulo, \\ para a obtenção do título de Doutor em \\ Antropologia Social.
}

Orientador: Profa. Dr. Lilia K. Moritz Schwarcz

São Paulo

2007 
Para meus irmãos Ana e João, meus grandes companheiros de viagem 
Resumo

Palavras-chave: violência, crime, juventude, sociabilidade, justiça, etnografia

Tomando o conflito como um dado da vida social, esse trabalho procura entender de que maneira ele, na sua forma de violência e criminalidade, se mistura ao cotidiano da cidade de São Paulo, provocando a pergunta: a violência pertence à regra ou é da ordem da exceção? A leitura espacializada do fenômeno construída pelos dados de homicídios no Brasil e em São Paulo, a etnografia de um bairro da Zonal Sul de São Paulo, e os dados sobre jovens cumprindo medidas sócio-educativas, são os pontos de partida para refletir sobre os altos níveis e as modalidades de violência empreendidas na sociedade brasileira. A pesquisa permite acompanhar como a violência entre e sai da vida de pessoas que não têm nenhum tipo de vínculo formal com a criminalidade organizada, as vezes com uma sutileza perversa, acionando praticamente todas as esferas da vida em comunidade a ponto de ser tomada como um grande pano de fundo para a própria existência. São evidenciados os limites da justiça e do aparato democrático num contexto de vulnerabilidade, as redes que amparam o envolvimento com o crime, e a privatização, em múltiplos sentidos, da segurança que empresta novos significados às idéias de contenção e repressão. As estratégias para enfrentála, as mudanças nas relações e interações entre os atores sociais, bem como suas constantes negociações, revelam uma cosmologia interna e partilhada, capaz de naturalizar a violência.

\section{Abstract}

Key words: violence, crime, sociability, youth, justice, ethnography

Considering conflict as part of social life, this dissertation seeks to understand in which way, when expressed as violence and crime, conflict can join the city of São Paulo's daily life, provoking the question: is violence part of the rules or is it exceptional? The comprehension of the phenomena from its spatial perspective - through the homicides data form Brazil and form São Paulo - the ethnography from a neighborhood at the south region of the city and data regarding juvenile offenders are the starting point to reflect about the high levels and the modalities of violence undertaken in Brazilian society. The research follows how violence can go in and out from lives of people that have no formal ties with organized crime, sometimes in a tenuous and perverse way, triggering virtually all spheres of community-life to the point that can be took as a setting for existence itself. The limits of Justice and of the democratic apparatus in a context of vulnerability are displayed, as much as the networks that sustain the involvement with crime. Also the privatization of security in many respects, that lends new meanings to the ideas of restraint and repression. The strategies to address the problem, the changes in the relationships and interactions between the social actors, and their constant negotiations, reveal an intern and shared cosmology, capable of naturalizing violence. 
Agradecimentos.

Entrando em campo e apresentando as armas

Pg. 6

Pg. 9

I. Objeto em transformação.

Pg. 13

II. Etnografia multisitiada - etnografia de uma idéia............................

Pg. 20

III. Uma história em 4 tempos e uma prorrogação.

Pg. 27

Capítulo 1 -

A violência enquanto tema, objeto, e regulador das relações cotidianas

Pg. 31

I. A configuração de um fenômeno

Pg. 34

II. São Paulo e o quadro das mortes violentas .................................

Pg. 43

III. Custos da Violência...

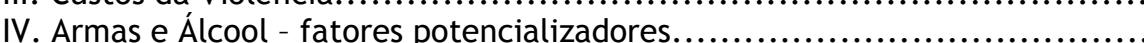

V. Violência e Criminalidade

V. Departamento de Homicídios e Proteção à Pessoa - pistas para a

investigação.

VI. Variações sobre um mesmo tema - um bar de Diadema e o cachorro do vizinho.

Pg. 53

Pg. 57

Pg. 62

Pg. 65

Pg. 72

Capítulo 2 - Longe do Crime, perto da Violência

Pg. 74

I. À direita na padaria

Pg. 76

II. Fazendo história na violência............................................

Pg. 85

III. Um grande Campo de Futebol.................................................

IV. Jogo de futebol e a ameaça de morte.........................................

V. História do tio.

Pg. 92

Pg. 95

Pg. 99

VI. A fumaça do bom direito $\mathrm{X}$ o perigo da liberdade............................

VII. Gravidez pela mão

Pg. 103

VIII. Suicídio induzido.

Pg. 109

Pg. 118

Capítulo 3 Redes - Juventude e Criminalidade

Pg. 121

I. Um Raio X da infração.

Pg. 124

II. Causas e conseqüências.

Pg. 129

III. Um cotidiano de violência.

Pg. 135

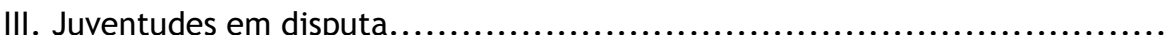

IV. Violências possíveis

Pg. 153

Pg. 161

Capítulo 4 - Sociedade e Estado - as dimensões coletivas e individuais da violência

Pg. 167

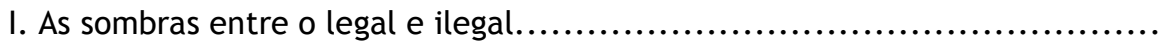

Pg. 181

II. Violência e Instituições.

Pg. 190

Fim de partida, começo de jogo: Filhos da Terra Futebol Clube

Pg. 198

Bibliografia

Pg. 211

Anexos

Pg. 225 


\section{Agradecimentos}

Mais do que escrever uma tese, um doutorado como um todo leva muito tempo. Durante esse longo período pude contar com a ajuda, contribuição, interlocução, carinho e o cuidado de muitas pessoas.

Agradeço aos funcionários do Departamento de Antropologia, em especial Ednaldo e Ivanete.

O professor Julio de Assis Simões debateu esse trabalho em duas ocasiões: logo no ingresso no doutorado, no curso Seminário de Projetos e, novamente, no exame de qualificação. Em ambas oportunidades seus comentários foram fundamentais para a pesquisa. Além dele, no mesmo curso, tive a oportunidade de ter meu trabalho comentado pela Professora Eunice Durham, a quem agradeço as sugestões e, sobretudo, as provocações positivas.

Eduardo Marques também participou do exame de qualificação e contribuiu de maneira importante para os rumos da pesquisa. Além disso, Eduardo foi extremamente generoso ao me apresentar um mundo novo de referências bibliográficas

Sylvia Caiuby e Jose Guilherme Magnani são referências na minha formação desde os tempos da graduação.

Agradeço Fernanda Peixoto pelo interesse pelo meu trabalho e pelo seu constante bom humor.

Rui Murrieta, a despeito da nossa distância temática, me fez indicações bibliográficas importantes.

A colaboração com Francesco Jodice, Boris, Beto Shwafaty, Giovana Silva e André Kobashi permitiu a realização do filme sobre o "Filhos da Terra Futebol Clube”.

Renato Campos DeVitto e Renato Cymbalista, fizeram sugestões preciosas ao trabalho.

Renato Lima me ajudou de muitas maneiras desde a disponibilização de dados até várias sugestões cruciais envolvendo a tese.

Dennis Rodgers e Gareth Jones fizeram uma leitura criativa daquilo que seria um primeiro ensaio dos argumentos da tese.

Ao longo desses anos tive o privilégio de trabalhar com pessoas incríveis que se converteram em grandes amigos e com quem compartilho o desejo por um mundo diferente: José Marcelo Zacchi, Denis Mizne, Juana Kweitel, Cassio França, Luciana Guimarães, Josephine Bourgois e Karyna Sposato. O comprometimento e a criatividade de vocês são um refúgio e um estímulo permanente. Ao Zé devo um agradecimento especial. Um interlocutor constante durante toda minha trajetória de pesquisa, desde os tempos do mestrado, devo a ele (ou deveria te culpar, Zé?) ter conhecido o “mundo dos advogados". 
Quando eu achava que já tinha todos os amigos que precisava na vida, conheci Maria Emilia Bender para me mostrar que eu estava completamente errada. Nessa mesma categoria estão Thyago Nogueira, Renata Megale, Antonio Prata, Paulo Werneck, Chico Mattoso e Fabrício Corsaletti. 0 carinho e o interesse de vocês foram cruciais para encarar essa empreitada.

Com Antonio Prata pude ainda dividir absolutamente todas as minhas crises com a certeza de que no final concluiríamos que a vida era boa e o mundo tinha jeito.

Marcos Goés (Marquito), Márcio Teixeira, (Macarrão), Wagner Silva (Guiné) e Edinho tiveram a paciência de me escutar e discutir comigo muitos dos temas tratados nessa pesquisa. Fazer isso com amigos foi para mim um privilégio.

À minha famiglia: minha madrinha, Heloisa Pavan de Souza Marques, meu padrinho, Dadá, Tia Ana Brias e Tio Kiko Pavan, Fred, Laura, Fê e Cos. Só posso agradecer o carinho e a versatilidade de vocês no papel de família: acolhidas no Sahy, nossos debates sempre emocionados, Martinis fundamentais, as grandes capitais - espero poder vestir muitas coroas com vocês. E ao Germano, afinal, que esteve disponível em todos os momentos em que foi evocado.

Dona Ana me ajudou a manter minha vida minimamente em ordem ainda que em certas ocasiões isso parecesse impossível.

Aos meus pais, Cristina e Luiz, agradeço todo o apoio, o cuidado e, sobretudo, o interesse constante pela minha vida e minhas atividades. Tenho clareza de que minha escolhas, assim como o que resulta delas, são frutos da educação que vocês me proporcionaram.

Com meus irmãos, Ana e João divido tudo na vida. 0 que eu nunca poderia imaginar é que eles se converteriam também em grandes interlocutores acadêmicos, cada um na sua especialidade. Sem a acolhida do Mei em Berkeley e a imensa ajuda da Jack no final (exatamente o tipo de coisa que só os irmãos fazem), tenho certeza de que não teria chegado ao final dessa tese. Obrigada por tudo.

Ainda na minha família nuclear tenho que agradecer à minha outra irmã Renata Rizzi e à sua onipresença, que desafia as noções de tempo e espaço. Como se não bastasse tudo o que já dividimos, temos agora interesses e projetos acadêmicos compartilhados. Só posso pensar que tenho mesmo muita sorte.

Continuando no mundo da família, durante esses dez anos aprendi com meus amigos "Sextafeiras" o que são laços que existem para sempre e como é possível sempre reinventar a proximidade e a distância. Agradeço a Florencia Ferrari, Paula Pinto e Silva, Renato Sztutman, Stelio Marras, Rose Satiko, Silvana Nascimento, Valéria Macedo e Evelyn Schuler a presença próxima, a inspiração constante e, sobretudo, a cumplicidade.

Da minha relação fraternal com a Flo, que cuida tanto e tão bem de mim, ganhei uma afilhada e sobrinha que me proporcionou momentos de refúgio essenciais num ano tão atribulado. 
Devo à minha orientadora Lilia Schwarcz uma lista quase que interminável de agradecimentos. O primeiro e mais óbvio refere-se à sua disposição incondicional de continuar orientando uma pesquisa que não era da sua área. Mas, além disso, o interesse e rigor da sua leitura, a criatividade e profundidade das suas sugestões contribuíram de maneira crucial para a versão final dessa tese. Não posso deixar de registrar sua generosidade em relação aos meus prazos absurdos. Finalmente, como uma grande amiga, seu carinho foi sempre parte integrante desses dez anos de orientação.

Agradecer ao Alex, Pincha, Marina e toda a sua família não seria suficiente. Eles me acolheram com uma generosidade indescritivel, me mostraram os caminhos da pesquisa e me ajudaram a encontrar muitas das respostas que eu procurava. Obrigada por tudo isso. Sem a amizade de vocês esse trabalho não teria sido o mesmo nem teria os mesmos significados. 


\section{Entrando em campo e apresentando as armas}

$\mathrm{Na}$ época em que redigia a versão final desse trabalho, em julho de 2007, voltei ao meu lugar privilegiado de pesquisa para visitar os amigos que não via há algum tempo. Como de costume tive que enfrentar o trânsito e (também como de costume) me irritei com a desorganização dos carros, ônibus e pedestres na avenida projetada provavelmente para ser um "grande corredor de acesso", mas que sempre me pareceu muito mais uma grande confusão pavimentada.

Quarenta minutos depois eu chegaria ao meu destino. Estacionei o carro na frente da casa de Marcelo. Olhei a paisagem que me era absolutamente familiar: o campo de futebol, o bar, a associação de moradores, as casas no morro, até o pedaço que eu nunca tinha visitado durante todo o tempo em que freqüentei o bairro. Ainda que estivesse cansada de saber que esse era um dos bairros mais violentos da Zona Sul de São Paulo, minha ronda visual não era capaz de fornecer um único elemento que me permitisse saber ou dizer o que fazia daquele lugar uma área particularmente violenta. A paisagem carente enfatizava minha presença na periferia. Mas era só isso. E essa não era uma ilusão provocada pela familiaridade adquirida com a convivência. Desde a primeira visita à região procurei encontrar a violência, mas ela nunca se apresentou como um cartão de visitas local tal como as casas pobres, a ausência de saneamento ou os "gatos" de telefone que, de maneira óbvia, dotavam de significado o cenário ao meu redor.

Os dados que eu tinha em mãos, no entanto, eram de uma contundência nada discreta: desde que havia começado a pesquisa quase 800 pessoas morreram, vítimas de homicídios, somente no Jardim Ângela.

O contraponto a esses números reveladores era o fato de que nesse mesmo período eu não conheci nenhuma pessoa das minhas relações próximas que tivesse morrido. Ao menos não dessa forma.

Claro que o número elevado de mortes não é a única expressão da violência. Mas, incorporada ao dia-a-dia, ela se transfigura e se apresenta de muitas formas e talvez por isso seja tão difícil aprendê-la de imediato. Para além das mortes, a violência está nas conversas informais cotidianas, nas denúncias de violações de direitos, no medo das mães que evitam deixar que seus filhos freqüentem a rua sem supervisão, na má conservação da escola, e assim como pode ser associada a mais uma infinidade de temas, espaços e questões. 
Ao mesmo tempo em que a violência é óbvia, é praticamente impossível precisá-la no mesmo grau da sua obviedade. Nesse sentido, parece ser também impossível retratá-la na mesma proporção dos efeitos que ela provoca na vida das pessoas.

O século XX é classificado pela Organização Mundial da Saúde (OMS) como um dos períodos mais violentos da história da humanidade. Estima-se que 191 milhões de pessoas morreram como resultado direto ou indireto de conflitos. Desse total, metade eram civis. Ou seja, suas mortes não resultaram de um envolvimento direto com um conflito militar.

É fato que ao longo dos últimos 20 anos pudemos observar um aumento substantivo da criminalidade e da violência ao redor do mundo. De acordo com o último relatório da própria OMS, a violência está entre as principais causas de morte para pessoas entre 15 e 44 anos, sendo responsável por $14 \%$ dos óbitos entre os homens e $7 \%$ entre as mulheres, podendo ser classificada como uma verdadeira “epidemia”, dadas as suas proporções e efeitos devastadores ${ }^{1}$. Suas manifestações são variadas; a violência hoje é um fenômeno global que ganha tintas locais em diferentes regiões do mundo. Guerras entre países, guerras civis, atentados terroristas e criminalidade urbana, todas contribuem para que número de mortes por causas externas tenha crescido de maneira persistente nos últimos anos.

Nos países em desenvolvimento, a violência tem sua versão mais contundente na forma de criminalidade urbana; isto é, crimes contra o patrimônio como roubos, furtos e seqüestros e crimes contra a pessoa tais como os homicídios.

O Brasil ocupa hoje um lugar incômodo no ranking dos países mais violentos do mundo. Enquanto a média na Europa é de 5 homicídios para cada 100 mil habitantes, a média nacional está próxima dos 30 para cada 100 mil. 0 número assustador de homicídios, contudo, não é um fenômeno isolado. Ele faz parte de um quadro mais agudo de violência e de criminalidade, constituído no país ao longo das últimas décadas.

Nos próximos capítulos discutiremos as definições dos custos da violência e sabemos que os custos diretos e indiretos da violência para os países ainda não são calculados com precisão. Mas o Banco Interamericano (BID) estimou que no Brasil, algo próximo a 1.9\% do PIB é gasto na área da saúde, em virtude da violência urbana e outros 3.6\% são gastos em policiamento e no sistema judiciário ${ }^{2}$. Além disso, de acordo com a Secretaria Nacional de Segurança Pública (SENASP), no ano de 1999, por exemplo, enquanto o valor do PIB do Estado de São Paulo foi de 310 bilhões, o Poder Público gastou R\$ 4,2 milhões no combate à criminalidade só nesse

\footnotetext{
${ }^{1}$ World Health Organization, 2004.

${ }^{2}$ Morrison, Buvinic, Orlando, 2002.
} 
Estado. No orçamento de 2005-2006 do Governo do Estado, a segurança deve receber 18,3\% da receita destinada ao Executivo, superando áreas como saúde, habitação ou transportes, ficando atrás apenas da educação que deve receber $24,5 \%$ da verba.

Nesse sentido, não é de hoje que ambas, criminalidade e violência, converteram-se em temas associados à saúde pública, bem-estar social, economia, justiça e governança ${ }^{3}$.

Na América Latina, mais especificamente, houve um aumento da criminalidade em geral. As taxas envolvendo roubos, furtos, seqüestros e homicídios vêm crescendo nos grandes centros urbanos $^{4}$ e podemos dizer que o aumento da criminalidade no Brasil nas últimas décadas é um fenômeno associado à escalada da violência no país.

Diante de tal quadro, são estabelecidos novos padrões de sociabilidade, implicando uma nova leitura da cidade, dos espaços públicos, da sua organização espacial e arquitetônica ${ }^{5}$ e da própria oposição entre centro e periferia.

No segundo capítulo a caracterização da periferia de São Paulo sob o ponto de vista geográfico, urbano e social é discutida mais detalhadamente. Neste momento é importante ressaltar o caráter relacional da oposição centro/periferia como resultado de uma leitura espacial que implica uma dada perspectiva ${ }^{6}$. Sabemos que a ocupação e distribuição dos grupos na cidade é fruto também das intervenções do Estado (ou da ausência delas) na cidade $^{7}$ e por isso indicadores sociais são essenciais para circunscrever regiões de periferia. Mas os conteúdos culturais e políticos daquilo que é periférico, assim como sua heterogeneidade também devem ser reconhecidos ${ }^{8}$. Sob essa ótica, a periferia é tomada aqui “[...] menos como espaço de encapsulamento do que como multiplicidade irredutível, a um só tempo inequacionável e plenamente interconectável"".

Como esse trabalho trata da cidade de São Paulo, é preciso considerar, além das dimensões epistemológicas da categoria, a própria geografia da cidade. Ao falarmos periferias ao longo da tese, estamos nos referindo duplamente às regiões pobres da cidade e também às suas franjas geográficas, localizadas longe do centro físico de São Paulo. Regiões que nos interessam em função das suas altas taxas de homicídios.

\footnotetext{
${ }^{3}$ Moser, Bronkhorst, 1999.

${ }^{4}$ Lima, 2002.

${ }^{5}$ Caldeira, 2000.

${ }^{6}$ Revista Sexta Feira, 2006.

${ }^{7}$ Marques, 2005: 38.

${ }^{8}$ Marques, idem: 31. Eduardo Marque faz ainda uma revisão bibliográfica sobre o tema na sociologia e na antropologia. Em entrevista à Revista Sexta feira (2006), o antropólogo José Guilherme Magnani reconstrói o processo por meio do qual a periferia tornou-se um lócus de pesquisa para a Antropologia.

${ }^{9}$ Revista Sexta Feira, 2006: 6.
} 
No Brasil, particularmente, chama a atenção, de maneira dramática, o número de homicídios cometidos. No final da década de 1990, por exemplo, enquanto a taxa de homicídios ${ }^{10}$ era de 7,8 na Argentina, 4,1 na Croácia, 1,5 em Israel, 0,7 no Japão e 2,0 em Portugal, no Brasil, nesse mesmo período, ela era de 24,8 . No caso do município de São Paulo, chegou a 48,6 ${ }^{11}$. Hoje, a despeito da queda de homicídios no Estado de São Paulo nos últimos quatro anos e da queda do número de mortes causadas por amas de fogo pela primeira vez em 13 anos ${ }^{12}$, ainda estamos falando de um quadro agudo, com um número muito alto de mortes.

Deste modo, podemos dizer que o crime, a violência e conseqüentemente o medo, tornaramse características constituintes dos grandes centros urbanos brasileiros, gerando ainda mais medo, alimentando preconceitos e alterando e orientando o cotidiano do cidadão comum, bem como suas estratégias de proteção.

Fica claro porque então a violência e a criminalidade ${ }^{13}$ ganharam status privilegiados na pauta política de intervenção do Estado, enquanto objetos de pesquisas acadêmicas e temas de conversas do dia-a-dia. Elas impõem uma série de desafios interpretativos às Ciências Sociais, bem como ao Estado que tenta responder na forma de novas políticas públicas ao mesmo tempo em que procura administrá-las enquanto capital político.

Uma dimensão menos palpável do fenômeno, mas igualmente relevante, é a maneira como a população percebe a violência. Sabemos que não há uma correspondência factual entre violência real e violência percebida. Isto é, ainda que o crescimento da criminalidade não provoque um aumento proporcional nos riscos de vitimização, ele provoca um aumento da sensação de insegurança. Vivemos como se a violência estivesse igualmente em toda parte, quando ela de fato não está. Organizamos o cotidiano, como se corrêssemos os riscos correspondentes às taxas de criminalidade. Sabemos, porém, que se o medo se espalha de maneira uniforme, a violência é vivida de maneira desigual: um rápido olhar para os mapas de distribuição da criminalidade em São Paulo mostra que os bairros mais centrais da cidade

\footnotetext{
${ }^{10}$ Ao longo desse trabalho usaremos dois tipos de dados criminais. Valores absolutos de crimes a partir dos quais podemos avaliar a evolução numa série histórica e as chamadas "taxas de criminalidade", no caso de homicídios. Para efeitos comparativos entre países, cidades e distritos, ao invés do número absoluto de crimes, tais taxas são resultado do número de homicídios por 100.000 habitantes da região.

Alerto o leitor que garantir certa homogeneidade no que se refere às fontes ou ao período do qual falam essas estatísticas, foi um dos grandes desafios desse trabalho. A qualificação da informação a respeito da violência é em si um tema não apenas para a academia, mas também para as políticas no campo da segurança pública. Para amenizar eventuais problemas, procuro trabalhar num espectro temporal relativamente comum. Contudo, ainda hoje, não é possível encontrar numa mesma fonte todos os dados sobre a criminalidade metropolitana. As estatísticas criminais serão discutidas brevemente no capítulo 1 .

${ }^{11}$ World Health Organization, 2004.

${ }_{12}^{12}$ Ministério da Saúde, UNESCO, Ministério da Justiça, 2004.

${ }^{13}$ A distinção entre as categorias "violência" e "criminalidade" será objeto de análise nos capítulos seguintes do trabalho.
} 
concentram os crimes contra o patrimônio, enquanto as periferias sofrem a maioria dos crimes contra a pessoa.

Os últimos 25 anos sintetizaram no Brasil um processo de urbanização dos grandes centros metropolitanos traduzido, não apenas, mas também, numa melhora dos serviços e condições de vida na periferia ${ }^{14}$. Nos últimos anos, inclusive, indicadores econômicos apontam para uma redução também nos níveis de desigualdade no país ${ }^{15}$.

Simultaneamente, a nação assistiu ao fortalecimento das suas instituições democráticas. As sucessivas eleições, o processo de impeachment do então presidente Fernando Collor de Melo em 1992, o plebiscito sobre o regime e sistema de governo no Brasil em 1993, o referendo em 2003 acerca da proibição do comércio de armas e a criação das ouvidorias de polícia a partir de 1995, são alguns exemplos nesse sentido. O fortalecimento da sociedade civil, a proliferação das organizações não governamentais, o aumento dos espaços e mecanismos institucionalizados de reivindicação e participação popular, são processos que, com todas as suas falhas e fragilidades, também enunciam a consolidação da democracia no país.

Com efeito, uma vez que a violência também é compreendida como uma questão de desenvolvimento econômico e social em função de seus custos e impactos variados, diante de um quadro de reconhecidos avanços democráticos o aumento das taxas de criminalidade aparece como um elemento dissonante, como um contraponto que injeta complexidade a esses processos.

Reside nesse aparente paradoxo um dos indicativos de que a violência não pode mais ser compreendida apenas e tão somente como conseqüência ou efeito deste ou daquele cenário, como se fosse possível capturá-la num contexto determinado. Ela é hoje, por si só, na sua forma concreta e abstrata, o próprio contexto.

\section{Objeto em transformação}

Inicialmente, o objeto primordial dessa pesquisa eram os homicídios cometidos por jovens e contra jovens $^{16}$ nas periferias da cidade. Na época, em 2003, eu trabalhava numa organização não governamental ${ }^{17}$ e acabei vivenciando de forma marginal um episódio envolvendo dois

\footnotetext{
${ }^{14}$ Caldeira, 2000; Marques e Torres, 2005.

${ }_{16}^{15}$ Paes de Barros e Carvalho, 2006.

16 As definições de "jovens" assim como de "juventudes" serão discutidas no terceiro capítulo dessa tese.

${ }^{17}$ Entre 2002 e 2003 e depois novamente entre agosto de 2004 e julho de 2006, trabalhei no Instituto Sou da Paz, uma organização não-governamental localizada em São Paulo, cuja missão é "contribuir para a efetivação no Brasil de políticas públicas de segurança e prevenção da violência que sejam eficazes e pautadas pelos valores da democracia, da justiça social e dos direitos humanos, por meio da mobilização
} 
jovens que haviam matado um terceiro. A narrativa dos jovens sobre o acontecimento sugeria que $o$ ato de matar, ameaçar de morte ou estar ameaçado se apresentava como uma maneira plausível de resolver conflitos, como uma possibilidade concreta nas suas vidas e, de alguma maneira, como uma forma de sociabilidade.

Minha pesquisa de mestrado ${ }^{18}$ tratou dos jovens internos na FEBEM (rebatizada Fundação CASA - Centro de Atendimento Sócio-educativo a Adolescentes - desde dezembro de 2006) e do universo da Justiça da Infância e Juventude. 0 trabalho mostrava, entre outras coisas, que o tipo de crime ou apenas o gesto de cometer o crime trazia consigo uma série de implicações para além daquelas legais. Ao longo do percurso vivido pelos internos, desde o momento da sua prisão até o período que passavam internados, um conjunto de discursos era construído em torno do acontecimento em questão (o crime), seja pelos próprios jovens internos na FEBEM, pelos operadores do direito nas audiências, pelas famílias desses jovens ou ainda pela narrativa repetitiva da mídia a qual permaneceu praticamente idêntica ao longo desses anos. O lugar que o crime ocupava em cada um desses discursos nunca era, no entanto, estático: ora associa-se à trajetória individual de cada jovem, revelando, por parte dos mesmos, a vontade de fazer escolhas próprias, ora servia como elemento de desumanização, no caso da justiça. Em outros momentos o crime se apresentava como um elemento exógeno, um produto do meio, vitimizador das camadas mais pobres, carregando grande potencial de contaminação.

Contudo, em qualquer um desses papéis o crime tinha o poder de definir identidades, não de forma estática, mas compondo o jogo dinâmico de construção permanente de uma biografia, combinado com conseqüências práticas numa trajetória de vida, como é o caso de uma passagem pela FEBEM. Para alguns dos jovens entrevistados, o crime aparecia nas conversas como um dado biográfico fundamental. As perspectivas de futuro, por exemplo, eram todas construídas em cima desse fato.

As conclusões da pesquisa apontavam que era preciso, pois, compreender de que maneira a violência e o crime eram incorporados à vida das pessoas e desse grupo em particular.

As "sobras" da minha pesquisa na FEBEM, somadas às sucessivas conversas com os jovens envolvidos no homicídio relatado anteriormente e as altíssimas taxas de homicídio em São Paulo, desenhavam um campo de investigação relevante e provocativo.

da sociedade e do Estado e da implementação e difusão de práticas inovadoras nessa área". No segundo período trabalhei na área de políticas locais de segurança pública, tendo coordenado o II Plano Municipal de Segurança de Diadema.

${ }^{18}$ Minha dissertação "Rituais da Violência: a FEBEM como um espaço do medo em São Paulo" foi defendida no Departamento de Antropologia Social da Universidade de São Paulo (USP) em 2001. 
Não obstante, com o andamento da pesquisa, vivi situações ou meus “informantes” viveram situações, que me obrigaram a enxergar a violência de maneira mais difusa e não necessariamente ligada à criminalidade. Os homicídios ainda tinham um papel fundamental eram, afinal, a expressão mais contundente da fragilidade social empreendida pela violência. Mas ela não se encerrava ali. Entrava e saia da vida das pessoas, flutuava como um espectro. $\mathrm{E}$, deste modo, deveria ser compreendida na sua fluidez e profundidade e não apenas num único ato; o ato de matar.

$\mathrm{O}$ ato de matar ou os homicídios podem ser atribuídos à atividades e personagens diversos: os "pé de pato" (matadores profissionais), o cidadão comum que se envolve numa briga, as mortes praticadas pela polícia, os crimes cuja origem está no tráfico de drogas. Todas essas modalidades são encontradas hoje em São Paulo. É claro que um padrão prevalece sobre outro dependendo da região, da época, ou mesmo do interesse e da seleção daquele que observa.

Aos poucos ficava claro que tão grave e importante quanto as motivações por trás dos homicídios e da violência de uma maneira geral, era a forma como ela se misturava, de maneira quase que inseparável, ao cotidiano de pessoas que nada tem a ver com o crime. $\mathrm{E}$ como, ao fazer isso, ela é capaz de produzir comportamentos, representações, flexibilizar relações e reconstruir níveis de tolerância para o bem e para o mal.

Durante esses quatro anos, o tema da violência também passou por diferentes processos e, numa existência paradoxal, viveu constantes "novos ciclos", extremamente repetitivos - a cada nova "onda de violência" ou diante de um "crime bárbaro", os mesmos diagnósticos emergiam, revelando com isso a pouca criatividade também no campo das soluções. Os impasses colocados no debate público eram de uma monotonia cansativa e anunciavam uma aparente intransponibilidade dos problemas ao longo de mais de duas décadas ${ }^{19}$.

Por um lado, o desafio da pesquisa tornava-se ainda maior: o campo de estudo se pulverizava de maneira progressiva. Por outro, ele parecia pouco animador. A violência e o medo só cresciam e as pesquisas e políticas públicas pareceriam serem incapazes de intervir na realidade a ponto de transformá-la.

Nesse mesmo período, nos últimos cinco anos, os homicídios no Estado de São Paulo, uma exceção no país, diminuíram $71 \%$. E ainda que estejamos falando de um número alto em

${ }^{19}$ Muitos dos temas evocados no referido debate são também objeto de reflexão desse trabalho. Para ilustrar o argumento, vale a pena adiantarmos alguns deles: a redução da maioridade penal, uma política penal mais severa, uma justiça mais dura, mais polícia nas ruas, mais encarceramento e o endurecimento das leis em geral, são alguns exemplos recorrentes quando a segurança pública está em questão. 
comparação a outras cidades e regiões do mundo, a redução foi amplamente divulgada e festejada ${ }^{20}$.

Ironicamente, no entanto, o medo e a sensação de insegurança ganharam contornos cada vez mais dramáticos. Episódios como a morte de uma criança no Rio de Janeiro de forma brutal em 2007 ou a sucessão de ataques protagonizados pelo Primeiro Comando da Capital (PCC) em maio de 2006, são exemplos que sinalizavam a institucionalização de novas modalidades de violência, apresentando, no caso de São Paulo, atores até então desconhecidos, e agregando sofisticação não apenas aos fatos em si, mas às leituras possíveis.

O debate nesse contexto aproveitava para polarizar-se cada vez mais, reduzindo o cardápio de escolhas a serem feitas diante da violência. Hoje a centralidade do tema no debate público tem como um dos carros chefes a redução da maioridade penal ${ }^{21}$. Como veremos nos próximos capítulos os jovens são as vítimas preferências da violência letal no Brasil. Entretanto, mesmo diante de números dignos de um genocídio, lhes é reservado o lugar de algozes, o que parecem resumir - de maneira enganosa, mas não ingênua - as escolhas que vem sendo feitas para refletir e enfrentar a violência no Brasil.

Nos anos mais recentes o tema e a própria violência, em suas muitas versões, adquiriram uma importância inédita na vida das pessoas. Filmes como "Cidade de Deus", “Ônibus 174”, e, mais recentemente, "Tropa da Elite", ajudaram a ampliar o debate e as próprias arenas de discussão.

Aquilo que Tereza Caldeira identificou como "fala do crime ${ }^{22 "}$ ganhou proporções inimagináveis e, tal qual a escalação da seleção brasileira, todo cidadão tem hoje uma opinião sobre as causas e as soluções para a violência e para a criminalidade no país.

Como não se perder em meio às tantas modalidades de violências e violações presentes de maneira tão explícita no cotidiano de uma cidade como São Paulo? Em se tratando de uma

\footnotetext{
${ }^{20}$ Como veremos mais adiante, a paternidade da redução dos homicídios em São Paulo ainda é objeto de disputa e controvérsia. Mesmo assim a redução dos homicídios, elegendo o Jardim Ângela como símbolo, foi comemorada e difundida pelos jornais, pelo Poder Público, pelas ONGs que trabalham na região e pelas associações comunitárias locais.

${ }^{21}$ Em abril de 2006, o Senado aprovou a redução da maioridade penal para 16 anos.

${ }^{22} \mathrm{~A}$ autora identifica um catalisador e potencializador desse sentimento de vulnerabilidade e sujeição em relação à violência: a "fala do crime". Ou seja, "todos os tipos de conversas, comentários narrativas, piadas, debates e brincadeiras que têm o crime e o medo como tema" (Caldeira, 2000: 27). Tais falas expressariam, em primeiro lugar o sentimento de medo. Mas, além disso, na circulação de informações estaria compreendida a produção de informações e conseqüentemente de um imaginário a respeito do crime e das condições de segurança de São Paulo. A criação de tal imaginário está ligada à necessidade de reorganizar o mundo desorganizado pela violência.
} 
pesquisa, como dimensionar com propriedade o seu objeto e dar o seu devido valor sem se render à aparente onipresença do assunto?

Certamente tratar tudo como um único fenômeno prejudicaria as possibilidades interpretativas. Por outro lado, desconsiderar o continuum entre os fenômenos ou o seu potencial reprodutivo é também menosprezar uma de suas dimensão constituintes. E como conjugar na equação ambientes mais vulneráveis onde não há apenas uma regra sendo rompida, mas uma aparente supressão ou ausência completa da lei? Finalmente, como articular a dimensão individual dos acontecimentos com causas estruturais que alimentam a violência enquanto fenômeno social?

Do "ponto de vista do bandido", muita coisa também mudou ao longo do desenvolvimento dessa pesquisa. A compreensão do tráfico de drogas como um grande pai, o status social do emprego no tráfico, e até mesmo os ganhos materiais advindos do tráfico podem ser hoje amplamente problematizados. A "racionalidade econômica" que supostamente orientava as escolhas daqueles que se candidatavam ao trabalho junto ao crime organizado pode ser profundamente questionada nos dias atuais. E são muitas as razões: o tráfico já não paga tão bem assim dependendo da região e da oferta do "mercado de trabalho", o risco de morrer rapidamente é reconhecido pelos jovens, "sair do crime" é uma opção quase que inexistente, o medo ainda produz respeito, mas o status social de um criminoso pode ser ofuscado pela liderança comunitária, ou por outros tipos de conquistas tais como um emprego estável, o ingresso na faculdade ou ser um bom pai. É preciso compreender que a vida no crime não é uma escolha fácil, nem uma saída simples.

Diante desse quadro intricado, que parece espelhar a própria complexidade compreendida no fenômeno da violência, o objeto da pesquisa também se transfigurou. Aos poucos não eram mais os homicídios exclusivamente que eram o tema de investigação, mas a própria violência que aparecia cada vez mais incorporada à vida cotidiana de pessoas que não necessariamente estavam ligadas ao crime organizado ou não organizado, mas que encontram-se sujeitas, muitas vezes, à sua lógica e regras. É como se fosse impossível fugir dela por completo.

Paralelamente, os últimos vinte e cinco anos comportaram uma extensa produção acadêmica sobre o assunto, assim como assistimos à conformação de um campo epistêmico dos estudos da violência no Brasil ${ }^{23}$. As explicações oferecidas pelos autores são variadas, tal como é o próprio fenômeno.

${ }^{23}$ De acordo com o levantamento de Adorno e Lima (2007) (comunicação apresentada na reunião da ANPOCS/2007) nos últimos dez anos foram produzidos mais de 8.000 trabalhos com palavras-chave "violência". 
Há uma nítida disputa explicativa para criar - seja ela no campo da teoria, seja na esfera das políticas - um modelo capaz de caracterizar São Paulo com a mesma objetividade e certeza que se fala do Rio de Janeiro, onde o papel do tráfico de entorpecentes e armas é central, inquestionável e parece, pelo menos numa perspectiva superficial, organizar a violência ou permite ao observador a compreensão das suas dinâmicas.

A redução dos homicídios em São Paulo é exemplar nesse sentido. Não há um consenso sobre o que teria motivado a redução desse tipo de crime no Estado. Não parece tampouco ser possível apontar uma relação de causa e efeito entre as políticas desenvolvidas nos últimos anos e a queda dos números. A redução dos crimes é atribuída a um conjunto extenso e variado de fatores: a ação do Estado, as atividades de ONGs nas áreas mais violentas, a mobilização comunitária nesses mesmos locais, a políticas específicas tais como a "Lei de fechamento de bares" em alguns municípios ou o Estatuto do Desarmamento, a criação do INFOCRIM ${ }^{24}$, a atuação do Ministério Público, o "Plano de combate aos Homicídios" do DHPP, ou mesmo ao aumento de evangélicos convertidos nas periferias, e a atuação da Polícia Militar.

As explicações aparecem ora isoladas, ora como uma combinação, dependendo de quem controla o discurso. São todas elas, porém, alvo constante de controvérsias no que diz respeito à sua eficácia, e revelam uma verdadeira batalha no campo político e institucional que conjuga a disputa pela paternidade dos supostos avanços no campo da segurança e uma disputa entre modelos de enfrentamento. O que funciona melhor, a repressão ou a prevenção? A segurança é um tema da polícia exclusivamente, ou deve ser tratada também como um assunto de políticas públicas em outras áreas tais como educação, urbanismo ou saúde?

Mas, além de um retrato da falta de clareza por parte das políticas ou de uma arena agitada de disputa política, esse feixe variado e pouco preciso de explicações é também um espelho fiel da multiplicidade de causas evocadas pela violência. Mesmo se nos restringirmos a São Paulo, poderíamos falar da criminalidade ligada ao tráfico de drogas, do crime organizado em geral, dos matadores profissionais, dos conflitos interpessoais, da criminalidade violenta associada ao crime contra o patrimônio ou dos seqüestros relâmpagos que tanto aterrorizam os paulistanos.

\footnotetext{
${ }^{24}$ Sistema de Informação Criminal da Secretaria de Estado da Segurança Pública, criado em 2000. É um sistema eletrônico de informação que permite a comunicação de todos os Distritos Policiais na cidade de São Paulo, produzindo um mapeamento dos dados estatísticos de criminalidade.
} 
A pesquisa deslocou, portanto, suas intenções. Não para fugir da tarefa interpretativa a qual havia se proposto, mas como a única estratégica capaz de abarcar todas essas modalidades. Não basta e não nos interessa apontar as motivações dos homicídios praticados nas periferias de São Paulo. Parece mais importante e significativo compreender como essa diversidade de oportunidades para matar, como esse conjunto grande e variado de atores capazes de solucionar seus conflitos de maneira tão violenta e pretensamente definitiva, contribui para a construção de uma sociabilidade que sorve essa violência, convertendo-se numa armadilha reprodutiva, capaz de ampliar ainda mais o elenco de pessoas capazes de matar.

Nesse sentido, não se trata de mergulhar nas brechas de um tecido social esgarçado, mas sim de reconhecer e compreender a reconstrução de um tecido do qual a violência faz parte da trama.

Numa entrevista ao Caderno Mais!, o documentarista João Moreira Salles chama a atenção para o imobilismo do discurso da violência:

“Uma coisa que aprendi é que o discurso da violência é de uma monotonia acachapante. Lembra as ladainhas das seis da tarde. As mesmas palavras, de novo, de novo"25.

O comentário que a princípio pode parecer um pouco intolerante é, na verdade, um tributo de precisão na qualificação do discurso da violência e sua imobilidade. Não há como saber quais as intenções de Salles nessa fala, mas o que parece ser uma constatação de quem "joga a toalha", é, na verdade, uma provocação ao tema, àqueles que lidam com ele em diversos níveis. O discurso da violência essencialmente continua o mesmo. Os problemas são os mesmos, apenas mais graves.

O comentário de Alba Zaluar sobre o diagnóstico do sistema penitenciário brasileiro nos anos 80 é exemplar como ilustração:

“[...] As calamidades do sistema penal brasileiro constituem parte importante da discussão. Esse tema foi muito bem estudado na virada da década de 80 , apontando para os absurdos da superlotação, da deterioração dos presídios e penitenciarias, da ineficiência do Judiciário que mantinha presos com penas já cumpridas ou fruto de erros judiciários. Hoje se discute, sobretudo, as medidas mais práticas de adoção de penas alternativas e mudanças no Código Penal. Tais como a descriminalização de certos 'crimes sem vítimas', como o uso e o comércio de substâncias psicoativas"26.

\footnotetext{
${ }^{25}$ Folha de São Paulo, 26.03.2006.

${ }^{26}$ Zaluar, 1999: 27.
} 
O parágrafo acima serve perfeitamente para descrever, com precisão etnográfica, os dias atuais, 27 anos depois. A sensação de que nada mudou, porém, é perigosa. Na sua aparente imobilidade, a violência vai sendo incorporada das mais diversas formas, como parte da vida. Uma violência que ainda choca, mas que é contraditoriamente naturalizada. E depois de tantos anos de convivência, parece não restar outra opção senão aprender a conviver com ela - o que é ainda mais grave.

\section{Etnografia multisitiada - etnografia de uma idéia}

Se a violência é difusa, percebida, tolerada e representada de muitas formas, na sua condição de objeto de pesquisa tais características seguem reproduzidas. Perseguir o objeto demanda, assim, acessar níveis distintos de ação e de representação da violência.

Em "Friction: an Ethnography of the global connection", a antropóloga Anna Tsing ${ }^{27}$, aponta o "conflito" como gerador ou impulsionador de ação social. De acordo com a autora, os contextos sociais nos quais diferentes lógicas (ou distintos modos culturalmente construídos de entender e conceber um determinado tema) se encontram e relacionam-se entre si são capazes de criar o que ela define como "fricção". É nesse atrito gerado nos encontros entre “diferentes" que são produzidos novos arranjos culturais de ação e de exercício do poder. A fricção entre diferenças (diferenças entre regimes de verdade, concepções de mundo, formas de representação, de agência etc.), seria o motor das relações socioculturais.

Tsing usa essa moldura teórica para tratar dos movimentos ambientalistas globais e globalizados. Ainda que as temáticas sejam distantes, há um paralelo, pelo menos do ponto de vista metodológico, relativo à dispersão daquilo que pode ser considerado um dado etnográfico.

Evoco, portanto, a possibilidade anunciada por Tsing de refazer redes e de refletir sobre o encontro dos significados associados à violência em contextos distintos. E, desse modo, a etnografia desse trabalho está menos ligada às suas dimensões espaciais (ou aos seus limites territoriais), mas mais à capacidade de circulação e de reprodução da violência e dos discursos à ela associados.

Para tanto, numa tentativa de me aproximar e de refletir sobre estruturas e processos sociais a partir de experiências do cotidiano, a realização da pesquisa recorreu a arenas diversas de produção de informação.

${ }^{27}$ 2005: 5. 
Do ponto de vista metodológico é possível separar e apresentar esses espaços da seguinte maneira: para medir e circunscrever a criminalidade esse trabalho faz uso dos levantamentos estatísticos da Fundação SEADE, que vem medindo a criminalidade em São Paulo há mais de uma década; dos dados do DATASUS, do Banco de Dados do Sistema Único de Saúde e dos dados da Secretaria de Segurança Pública do estado de São Paulo, que registra os crimes na capital, no município e no Estado a partir dos Boletins de Ocorrência. Além dos dados em si, as estatísticas nos oferecem uma perspectiva macrosociológica, mostrando que estamos tratando de um fenômeno de grandes proporções, que hoje retrata a sociedade brasileira.

Além dos dados estatísticos e das taxas criminais, a pesquisa também faz uso de mapas e indicadores construídos nos últimos anos, quase todos encomendados pelo Poder Público, na condição de subsídios para a formulação de políticas públicas. São ferramentas tais como o Índice de Vulnerabilidade Juvenil ${ }^{28}$, o Mapa de Risco da Violência ${ }^{29}$, os Mapas da Violência ${ }^{30}$ e o Mapa de Vulnerabilidade Social ${ }^{31}$.

O terceiro capítulo traz dados de uma pesquisa realizada pelo Ilanud (Instituto Latino Americano das Nações Unidades para a Prevenção do Delito e tratamento do Delinqüente) para avaliação de programas municipalizados de cumprimento de medidas sócio-educativas em meio aberto, além de dados sobre jovens cumprindo medidas sócio-educativas do Governo Federal e da Fundação CASA.

Além disso, minhas atividades profissionais na área foram sempre um reduto rico de informações $^{32}$. O contato e convivência constantes com Policiais, Guardas Municipais, operadores do direito, "ongueiros" e gestores públicos me proporcionaram parte dos relatos que apresento nesse trabalho e muitas das minhas reflexões.

Ao mesmo tempo, realizei uma etnografia num bairro da zona Sul de São Paulo, uma das regiões com as maiores taxas de homicídio da cidade. Partindo da história de Marcelo, um jovem morador do Parque Novo Santo Amaro, tive acesso a jovens envolvidos com a criminalidade ou não, lideranças comunitárias e outros moradores da região. Cada um desses

\footnotetext{
${ }^{28}$ Fundação SEADE, 2007.

${ }^{29}$ Centro de estudos de Cultura Contemporânea (CEDEC), 1996.

${ }^{30}$ Waiselfisz , 2002, 2004 a; Waiselfisz, Athias, 2005.

${ }^{31}$ Centro de Estudos da Metrópole/CEBRAP, SESC, SAS-PMS, 2004.

${ }^{32}$ Desde setembro de 2006 assumi o cargo de Diretora executiva do Ilanud. O instituto tem como missão "o fortalecimento do Estado de Direito, o respeito aos direitos humanos, a preservação da paz e o desenvolvimento social, por meio da realização de pesquisas, do desenvolvimento ou apoio a projetos inovadores e da assessoria para a formulação de políticas públicas. Para tanto, atua nas áreas de 'Justiça da Infância e Juventude', 'Justiça Criminal e Sistema Prisional' e 'Segurança Pública e Prevenção da Violência"".
} 
personagens traz uma seleção de argumentos para explicar o número alarmante de mortes no seu bairro, assim como a incorporação da violência às suas vidas.

Num texto clássico da antropologia, Sidney Mintz $^{33}$ apresenta um estudo sobre trabalhadores rurais em Porto Rico, preocupado, entre outras coisas, com os efeitos da ocupação americana naquela comunidade. Faz isso exclusivamente por meio da história de vida de um desses trabalhadores: Don Taso. A aposta de Mintz é que ao contar a história do que ocorreu com Taso equivaleria, em algum nível, a contar a história de pessoas como Taso.

“Taso é representativo de seu tempo, de seu lugar e de seu povo, precisamente porque sua narrativa pessoal, enriquecida por sua perspectiva incomum, incorpora a experiência de uma comunidade, uma região e um país, sendo que cada uma delas em níveis de realidade e abstração algo diferentes ${ }^{34 ”}$.

Não usei o recurso da história de vida propriamente, mas me apoiei na trajetória de Marcelo para conhecer aquele universo, formular minhas hipóteses e para ser apresentada a uma comunidade. Mas se Marcelo é um morador da periferia, ele é também pai, jovem, é, assim como eu, funcionário de uma Ong, mas também é uma liderança comunitária, é um líder no interior da sua família, um universitário - tudo isso ao mesmo tempo. Pretendo chamar atenção com essa observação para o fato de que os eventos e acontecimentos em sua vida dialogam com sua comunidade, mas também com o resto do mundo e, que, por meio da sua história seria possível contar a história de seu bairro, a história de São Paulo e da imigração, a história da juventude segregada e mais uma série de outras histórias.

Ainda que a etnografia tenha sido o método e a observação participante o norte constante das atividades de pesquisa, não é possível caracterizar minha investigação como uma pesquisa etnográfica nos moldes tradicionais, de inspiração Malinowskiana: não morei no Parque Novo Santo Amaro ou em nenhum outro bairro do Jardim Ângela, compartilho parte do universo simbólico com o sujeito pesquisado, não há um estranhamento absoluto ou mesmo uma delimitação espacial e geográfica rígida para a realização da pesquisa. É preciso dizer que mais do que uma etnografia do Parque Novo Santo Amaro, estou fazendo uso da investigação que realizei na região para refletir e falar sobre uma determinada forma de interação social.

\footnotetext{
${ }^{33} 1984$.

${ }^{34}$ Idem: 55 .
} 
Desse modo, é importante definir de antemão o status da etnografia nesse trabalho. Não se trata de uma etnografia de um lugar, mas uma etnografia de idéias que transitam em muitos campos - físicos e conceituais - além do próprio bairro. O resultado é um texto que traz a etnografia do bairro intercalada com informações resultantes de outros esforços de pesquisa. O objetivo dessa combinação foi cercar o objeto em suas muitas dimensões e adequar às demandas e inquietações teóricas às minhas limitações no que se refere à realização prática da investigação.

Além dos limites referentes ao meu tempo disponível para a pesquisa de campo em função da escolha pessoal de desde o ingresso no doutorado trabalhar paralelamente em período integral, é preciso problematizar os obstáculos de outra natureza, que foram se constituindo com o desenvolvimento da própria pesquisa.

Márcio Goldman recorre à imagem do candomblé "catar folha" para sintetizar um processo de pesquisa cumulativa por meio do qual seja possível, ao longo do tempo "catar" detalhes capazes de recompor uma realidade ${ }^{35}$.

Ainda ponderando sobre a metodologia de pesquisa de campo, o antropólogo carioca revela:

“[...] jamais tomei nota na frente dos meus 'informantes'. Por um lado porque ninguém era apenas informante, termo infame que a antropologia compartilha com a polícia: tratava-se muitas vezes de amigos (com os quais eu não me sentia à vontade de agir como 'pesquisador') e, sempre, de interlocutores, no sentido mais abrangente, ou seja, pessoas com as quais eu dialogava, concordava e discordava, expunha e escutava pontos de vista" ${ }^{36}$.

Minha entrada no campo foi garantida graças à relação que estabeleci com Marcelo e posteriormente com a sua família. Foi por meio deles que conheci outros moradores, pude freqüentar festas, tomar parte nas atividades da Associação de Moradores, etc. Como seria natural, o tempo e a convivência permitiram que nossos laços se estreitassem e aos poucos me vi diante dessa categoria sintetizada por Goldman, o informante-amigo.

Vivi então uma situação paradoxal: quanto mais próxima eu ficava da família e, sobretudo de Marcelo, mais eu tinha acesso àquele universo. Entretanto, ao mesmo tempo, mais eu fazia parte daquela realidade. Ainda que como a "amiga de fora", encontrei um lugar nas histórias que conto aqui e assim me envolvi - dessa vez não como pesquisadora - com muitos dos acontecimentos. Foi esse novo lugar que impôs uma série de limites até então impensados para as atividades de campo: a uma certa altura não me sentia mais confortável no papel de

\footnotetext{
${ }^{35}$ Goldman, 2006: 24.

${ }^{36}$ Idem.
} 
pesquisadora, dada a gravidade de determinados episódios fiquei sem poder freqüentar o bairro por alguns tempo, nem sempre o desenlace de determinadas situações eram do meu "gosto" ou estavam de acordo com aquilo que eu acreditava. Finalmente, a preocupação com a integridade e segurança de meus novos amigos se sobrepôs a qualquer interesse acadêmico. Tive, assim, que conjugar "em campo" essa aproximação que foi também restritiva. Ou melhor, fazem parte de uma maneira de etnografar pontual, digamos assim, e coadunada com a especificidade e "delicadeza" do campo que selecionei. No entanto, apesar de mais circunstanciada, a etnografia ganha um estatuto paralelo e estratégico neste trabalho, uma vez que é ela que permite iluminar, tensionar e problematizar temas contemplados de maneira mais olímpica, pela bibliografia. Por outro lado, se a etnografia significa a entrada num espaço sensível, e possível dizer que ela me permite tratar números com outro grau de familiaridade mas também de distanciamento. Os resultados podem ser vistos no conteúdo e também na forma como apresento a etnografia ao longo do trabalho.

Freqüentei o PNSA assiduamente entre os anos de 2004 e 2007. Não rebatizei meu campo como fez Norbert Elias com Winston Parva ${ }^{37}$, mas os personagens que aparecem ao longo da tese foram todos renomeados. Meu principal objetivo com isso foi o de preservar as pessoas, suas histórias e garantir, desse modo, sua privacidade e segurança. Os mapas e os dados que fazem parte dessa tese procuram aproximar minha reconstrução do real, dando uma dimensão concreta à esses lugares e às pessoas renomeadas.

É prudente lembrar a ressalva de Goldman quando o autor afirma que a observação participante significa "muito mais a possibilidade de captar as ações e os discursos em ato do que uma improvável metamorfose em nativo" ${ }^{38}$. A associação e alternância entre observação participante e participação observante ${ }^{39}$, que pode ser considerada já um clássico moderno da pesquisa antropológica em se tratando de determinados temas, parece resolver de maneira apropriada essa questão.

No meu caso não foi diferente. Mas a relação entre academia, militância e intervenção, por caminhos que não são necessariamente ou exclusivamente a reflexão teórica, obrigam uma revisão dessas "modalidades" de atividade de pesquisas.

A configuração do urbano na condição de objeto da antropologia já foi capaz de consolidar um debate amplo e avançado na antropologia brasileira ${ }^{40}$. Mas nesse caso, não se trata de

\footnotetext{
${ }^{37}$ Elias, 2000.

${ }^{38}$ Op. cit: 27.

${ }^{39}$ Cardoso, 1988.

${ }^{40}$ Magnani, Torres, 1996; Velho, 1980; Velho, Kuschinir, 2003, são alguns exemplos.
} 
optar por uma antropologia na cidade ou da cidade $^{41}$, na medida em que a cidade nesse trabalho não aparece apenas como contexto ou tema. Ela é sobretudo um dado, uma vez que as relações que constroem e resultam da oposição centro $x$ periferia, a distribuição geográfica dos crimes, a desigualdade e heterogeneidade que caracterizam o cenário urbano são todos elementos fundamentais para a análise.

Frugoli $^{42}$ identifica um conjunto de referências teóricas oriundas da sociologia cujo campo investigativo seria o espaço urbano. Tais estudos, diante do fenômeno definido como "problemas urbanos", tinham no seu horizonte subsidiar intervenções ou políticas públicas de enfrentamento dos referidos problemas.

O tema dessa pesquisa em particular, somado ao fato de que ao longo de todo o doutorado venho trabalhando em organizações cujas atividades estão ligadas à intervenção e transformação da realidade, afetou (de maneira positiva, espero) minha compreensão do problema.

Mas essa tampouco representa uma encruzilhada nova. Não é de hoje que a área de violência urbana está povoada pelos chamados intelectuais cujas atividades não estão restritas à produção acadêmica, mas que têm uma profunda interface com a formulação de políticas.

Tal fato não impede, no entanto, a separação dos espaços de reflexão e de atuação (o que não é em momento algum um exercício simples). Nesse sentido, não chamaria essa pesquisa de uma "antropologia aplicada", mas de "antropologia implicada" nos termos de Bruce Albert ${ }^{43}$.

Logo, se as fontes de pesquisa são de natureza variada e o percurso da pesquisa foi bastante plural, parte disso deve-se às diversas modalidades de minha inserção em campo. Viveiros de Castro $^{44}$ chama a atenção para a singularidade da pesquisa antropológica. Esta residiria no fato de que a própria realização da pesquisa se dá no estabelecimento de uma relação entre pessoas que, ainda que provenientes de universos distintos, compartilham uma natureza comum. 0 autor sugere, então, que ao travar essa relação, pesquisador e pesquisado assumem papéis determinados e que isso acaba por influenciar o resultado da investigação. No meu caso em particular, posso dizer que não assumi um, mas vários papéis. Fiz pesquisa no papel de "antropóloga", mas também o fiz na condição de "ongueira", ou mesmo como mais uma participante de um evento social determinado; fosse ele uma festa, um show, ou

\footnotetext{
${ }^{41}$ Magnani, 2002.

${ }^{42}$ Frúgoli Jr., 2005.

43 Albert, 1995.

442002.
} 
uma cerveja entre amigos. Essa alternância, contudo, não garantia uma "exclusividade de atuação". Não acredito que seja possível abandonar tais lugares por completo; acredito sim na possibilidade de privilegiar algum deles em determinadas arenas.

Foi dessa maneira que pude estabelecer um número grande de pequenas conversas que me revelavam a extensão e difusão do objeto de investigação, ao mesmo tempo em que consolidavam sua magnitude. Quando na periferia, a morte foi sempre um assunto. Conheci dezenas de jovens que perderam irmãos, amigos, parentes ou colegas dessa maneira. Freqüentei festas onde os raps cantados ao vivo eram extensas narrativas lamentando a morte dos amigos, um depois do outro. No meu trabalho com a Guarda Municipal em Diadema, ouvi diariamente casos de brigas de bar ou de vizinhos onde o desfecho era a morte. Descobri que o maior medo das mães é a morte do seu filho homem. A cada incursão a campo, as estatísticas tão familiares ganhavam uma história.

Um doutorado leva muito tempo. E se há de fato, como afirma Clifford Geertz, uma desproporção por parte da Antropologia na sua capacidade de identificar e resolver problemas $^{45}$, um doutorado leva tempo suficiente para descobrir histórias (ou os problemas), assustar-se com elas, acostumar-se com elas, para, finalmente, reconhecer os limites da pesquisa e do pesquisador.

Já no último ano da pesquisa fui informada por um amigo advogado da existência anedota que conto a seguir, segundo ele um clássico das Ciências Sociais, mas que eu desconhecia até então:

“Tem dois tipos de antropólogo: o antropólogo coitadinho do índio e o antropólogo coitadinho do pobre". A ironia de meu colega dirigida às escolhas dos antropólogos talvez dialogue com a constatação de Durham quando diz que “'[...] a antropologia sempre demonstrou especial interesse pelas minorias despossuídas e dominadas de todos os tipos (índios, negros, camponeses, favelados, desviantes e 'pobres' em geral) em detrimento do estudo dos grupos ou classes politicamente dominantes e atuantes. Quanto aos temas, sempre revelou uma afinidade particular por aqueles que eram claramente periféricos à grande arena das lutas políticas: dedicou-se muito mais ao estudo da família, da religião, do folclore, da medicina popular, das festas do que à análise do Estado, dos partidos políticos, dos movimentos sindicais, das relações de classe, do desenvolvimento econômico ${ }^{46}$."

\footnotetext{
${ }^{45}$ 2001: 43

${ }^{46}$ 1988: 18 .
} 
A escolha da violência como tema, contudo, não precisa ou deve ser lida como uma escolha pelos pobres ou pela periferia, ainda que hoje, com veremos, ela vitimize de uma maneira capaz de impor segregações inéditas a essa parcela da população, o que por si só seria uma boa justificativa. Mas a escolha é, antes de mais nada, resultado do interesse sobre a desigualdade estrutural da sociedade brasileira e uma de suas modalidades. A violência urbana é um retrato das particularidades da cidadania no Brasil, resumida naquilo que Wacquant ${ }^{47}$ identificou tão bem quando sublinha a simbiose entre manutenção da ordem de classe e a manutenção da ordem pública: o "controle dos miseráveis pela força”.

Estudar hoje a violência no Brasil significa tratar de desigualdades antigas, talvez estruturais, e suas atualizações recentes.

Tomando o conflito como um dado da vida social, esse trabalho procurou entender de que maneira ele, na sua forma de violência e criminalidade, vai aos poucos se misturando ao cotidiano da cidade de São Paulo, provocando a pergunta: a violência pertence à regra ou é da ordem da exceção? A resposta, mais do que um retrato congelado da realidade, tem a

pretensão de capturar a oscilação da violência entre esses dois universos. Ao fazê-lo, identifica os elementos envolvidos nesse processo, as estratégias para enfrentá-la e as mudanças nas relações e interações entre os atores sociais, bem como suas constantes negociações. Por fim, pretendemos discutir como de que maneira estamos lidando com uma cosmologia interna e partilhada, capaz de naturalizar a violência.

\section{Uma história em 4 tempos e uma prorrogação}

Não é o caso de refazer o percurso todo, mas, antes, de iluminar momentos destacados desta reflexão, que foi se fazendo de maneira pouco tradicional. 0 capítulo que abre o trabalho procura desenhar o problema de pesquisa de maneira ampla. A partir de dados de homicídios no Brasil e em São Paulo, faz uma leitura espacializada do fenômeno valorizando sua diversidade, articulando versões locais com seus significados mais abstratos e refletindo sobre seu conteúdo social. Dialogando com elementos que compõem o universo reflexivo acerca da violência - seus custos, fatores potencializadores e a produção de informação sobre a criminalidade - o capítulo tem como objetivo circunscrever o objeto de pesquisa.

O segundo capítulo traz uma incursão ao Parque Novo Santo Amaro. Por meio de fragmentos da história de vida de um jovem e de sua comunidade, o texto pretende mostrar como a

\footnotetext{
${ }^{47} 2001$.
} 
violência entre e sai da vida de pessoas que não tem nenhum tipo de vínculo formal com a criminalidade organizada, as vezes com uma sutiliza perversa, acionando praticamente todas as esferas da vida em comunidade a ponto de ser tomada como um grande pano de fundo para a própria existência. São evidenciados os limites da justiça num contexto de vulnerabilidade, a emergência de novos atores sociais e os impasses criados quando se aprende - quase sempre de maneira compulsória - a conviver com a violência.

No capítulo 3 a violência é tratada na sua forma de infração ou criminalidade. Os dados do Governo Federal, da Fundação CASA a respeito dos jovens internados e da pesquisa realizada pelo ILANUD com jovens cumprindo medida socioeducativa de Liberdade Assistida são pretextos para refletir sobre a vinculação desses adolescentes com a criminalidade, o papel do contexto e as relações de causalidade envolvidas. O caminho nesse capítulo é inverso: partimos do crime cometido por esses jovens para radiografar o contexto em busca das redes de ilegalidade que amparam esse processo de envolvimento com o mundo do crime.

O último capítulo retorna ao Parque Novo Santo Amaro abordando alguns episódios de violência institucional. São confrontados o papel das instituições, os limites do aparato democrático e a privatização em múltiplos sentidos da segurança que empresta novos significados às idéias de contenção e repressão.

A tese traz por fim uma reflexão sobre a prática do futebol, no contexto em que etnografei, e que aparece no filme do qual sou uma das produtoras: "Filhos da Terra Futebol Clube". Nesse pequeno vídeo, apresento um dos times de futebol do Parque Novo Santo Amaro onde jogam muitos dos entrevistados nesse trabalho, incluindo Marcelo. O time - e tudo o que ele mobiliza e simboliza - é objeto de reflexão das considerações finais do trabalho.

Vale notar que o filme não foi realizado como produto dessa pesquisa. Ele é resultado do pedido dos jogadores que queriam ter um registro da história do time e do bairro. Pessoalmente, essa foi uma das formas que encontrei de retribuir minha presença - por vezes intrusa - no seu dia-a-dia. Por isso, sua narrativa não tem o formato de um documentário, disposto a discutir de maneira crítica a sociabilidade local, mas traz apenas a pretensão de ser um registro capaz de anotar e celebrar a trajetória do "Filhos". Como ferramenta de pesquisa, sua realização foi mais uma oportunidade (extremamente rica e divertida) de interação com aquela comunidade. 0 interessante é que o grupo pede para ser representado a partir da prática do futebol e de uma sociabilidade que os afasta da imagem da violência. Rituais comungam, refletem mas criam e no campo novos registros vão se desenhando, mostrando como identidades são negociadas com as bolas nos pés. 
O pequeno filme "Filhos da Terra Futebol Clube" faz parte dos anexos da tese.

No último final de semana de novembro de 2007, o filme foi exibido na festa de final de ano do Filhos da Terra para os jogadores e suas famílias. Não pude participar do evento, mas soube que a platéia ficou feliz com o resultado e que as participações de Mundinho (que chorou quando era entrevistado e chorou novamente ao assistir ao filme) e Zé Grande, ambos moradores e jogadores antigos do bairro e do time - foram aplaudidas pelos espectadores.

Em maio de 2005 fui convidada a participar de um seminário na London School of Economics cujo título era "Youth Violence in Latin America: Gangs, Street Children, and Juvenile Justice in Perspective". Apresentei meu trabalho na sessão sobre gangues juvenis (questionando a funcionalidade do modelo para o caso brasileiro). As exposições eram majoritariamente de pesquisadores estrangeiros falando sobre a América latina, muitos deles sobre o Brasil. Ao ouvir uma série de hipóteses e teorias sobre as expressões da violência na minha cultura, me senti a própria nativa e descobri, finalmente, que esse é um lugar absolutamente desconfortável.

Além de uma ótima oportunidade para debater meu trabalho, o evento foi bom para pensar sobre uma série de outras questões associadas a ele: os limites na intenção de conhecer a cultura do "outro" e o diálogo entre o Norte e o Sul no que se refere à produção de conhecimento, eram algumas delas. Mas o incômodo serviu para refletir, sobretudo, sobre minhas escolhas e meu lugar enquanto pesquisadora.

Estudar o tema da violência no Brasil ganha uma conotação particular diante dos níveis de violência empreendidos na sociedade brasileira, associado ao lugar que eu - agora individualmente - ocupo na economia dos riscos que a acompanham. Pessoalmente, os desafios implicados nessa escolha eram inúmeros e de natureza variada: não cair na armadilha de naturalizar a violência que é descrita ao longo do trabalho; conseguir encontrar o equilíbrio entre me familiarizar com a violência, mas ser capaz de seguir me chocando com ela durante todo esse tempo; não me render completamente ao medo e à sensação de insegurança, problematizados aqui, mas estar ciente de ambos - afinal, moro em São Paulo e fui assaltada algumas vezes no período de realização da pesquisa. 
Logo, concluir o doutorado teve para mim inúmeros significados.

Um deles me parece particularmente relevante. A combinação entre "o trabalho e a tese" foi sempre um tema. Seja porque encontrar o tempo necessário para dedicar ao doutorado era uma preocupação permanente, seja porque estabelecer um limite saudável entre esses dois universos demandou minha (e sem dúvida da minha orientadora) eterna atenção.

Chego ao final convencida de que a interlocução constante entre a produção acadêmica e o “mundo da prática” só pode trazer benefícios para ambos os ambientes e, sobretudo, para quem se coloca nessa intersecção. Quero crer que comigo foi assim.

Empresto os princípios e as convicções que são tão necessários ao meu trabalho cotidiano como provocações teóricas ao meu objeto. Acredito, assim, que faz sentido advogar uma produção acadêmica que tenha no seu horizonte a transformação social.

Conviver com o tema de maneira tão próxima e integral sugere em certos momentos que o duelo com a violência é um daqueles que não se consegue ganhar. Mas como em muitas circunstâncias descritas nessa tese, mais uma vez a própria violência nos coloca diante de uma situação paradoxal: ao mesmo tempo em que nenhum esforço parece suficiente para dar conta do problema de modo definitivo, ela é tão grave e urgente que não nos permite simplesmente abandoná-la ou torná-la, apenas (se é que se pode falar em apenas) natural; cotidiana. Espero que esse trabalho tenha contribuído de alguma maneira - no campo conceitual, teórico, mas também prático - para refutar a idéia de uma batalha perdida e manter a bola em jogo. 


\title{
Capítulo 1 \\ A violência enquanto tema, objeto, e regulador das relações cotidianas
}

\author{
"Uma sociedade sem homicídios não é mais \\ pura do que uma sociedade sem paixões"
}

(Èmile Durkheim em Lições de Sociologia, 2000)

Durante três meses em 2006 fiz visitas constantes ao Departamento de Homicídios e Proteção à Pessoa da Polícia Civil de São Paulo $(\mathrm{DHPP})^{48}$. Além de conversar com delegados e investigadores, pude também ler alguns inquéritos de homicídios. Num desses dias, enquanto fazia a leitura de inquéritos, acompanhei e entrada de um novo caso no Departamento. Os investigadores me contaram que um jovem de 17 anos havia sido morto e que nos dias anteriores sua mãe e irmão tinham ido à polícia para testemunhar, relatando o acontecido e apontando, inclusive, os responsáveis pela morte do filho e do irmão. Naquele mesmo dia à tarde a equipe de investigadores havia detido dois dos suspeitos envolvidos no assassinato e, no momento em que eu lia um inquérito de outro crime, um dos acusados - também um jovem - foi trazido para ser interrogado. Tive que me mudar para sala ao lado. Poderia escutar o interrogatório, mas não assistir. Havíamos combinado que para a minha própria segurança eu não deveria ser vista pelos suspeitos interrogados ${ }^{49}$.

Enquanto escutava as perguntas da delegada e dos investigadores ao jovem, seguidas de suas respostas monossilábicas, comecei a leitura do inquérito desse assassinato em particular. A morte desse jovem não era uma qualquer. Antes do inquérito vi as fotos que faziam parte da investigação: numa se vê apenas uma cabeça descolada de um corpo. A foto seguinte mostra

\footnotetext{
${ }^{48}$ Criado em 1986, o Departamento de Homicídios e Proteção á Pessoa é um dos órgãos de execução da Polícia Civil, subordinado à Delegacia Geral de Polícia. Entre seu conjunto de atribuições estão: 1. apurar os crimes de autoria desconhecida, sendo eles consumados, tentados ou latrocínios (roubo seguido de morte), 2. apurar lesões corporais graves seguidas de morte de autoria desconhecida, 3. proteger a liberdade pessoal, vítimas sobreviventes, testemunhas e acusados ameaçados. A Divisão de Homicídios é dividida entre a "Divisão de Homicídios" e a "Divisão de Proteção à Pessoa".

${ }^{49}$ Ainda que pareçam distantes os riscos que eu poderia correr, essa equipe de investigação do DHPP é responsável pela averiguação dos homicídios ocorridos na Zona Sul da cidade. Ou seja, a região que eu freqüentava, desenvolvendo minha pesquisa. Esse procedimento pretendia evitar o risco de que eu fosse eventualmente vista por uma testemunha ou acusado conhecido ou que já tivesse me visto na região e fosse associada à polícia.
} 
um local diferente do primeiro, um terreno com uma grama rala onde está jogado, (imagino) o corpo do jovem sem cabeça. As fotos subseqüentes permitem ver os detalhes. A cabeça do jovem morto havia sido retirada do seu corpo com perfeição. Um corte sem falhas, em forma de curva, separava pescoço do tronco. Foi assim que ele foi encontrado: de um lado no mato, seu corpo sem cabeça. Mais adiante, na beira da rua estavam cabeça e o pescoço.

Li o inquérito e fui compreendendo a história. De acordo com o que estava relatado ali e a partir das conversas dos investigadores, a vítima trazia no seu histórico um leve envolvimento com o tráfico local, havia feito alguns pequenos serviços e, aparentemente, tinha deixado pendente uma dívida com o traficante. Segundo sua mãe, o jovem foi pego pelo grupo dos traficantes uma primeira vez. Nessa ocasião foi torturado, sendo colocado dentro de um barril com água até o pescoço, onde foi mantido por três dias. 0 jovem conseguiu finalmente fugir e desde o episódio não saia mais de casa para não correr o risco de ser pego novamente. Um dia, no entanto, segundo a versão de sua mãe, decidiu sair para procurar emprego junto com o irmão mais novo. Enquanto andavam pela rua avistaram um carro que vinha na sua direção. Rapidamente o jovem foi colocado dentro do veículo, para ser reencontrado, dias depois, morto, em pedaços, num terreno próximo à sua casa.

Desde o episódio, seu irmão, testemunha do rapto, parou de ir à escola e também não saía mais de casa. A mãe, com medo, foi testemunhar no DHPP. Situação raríssima, uma vez que, como veremos, há uma desproporção entre as garantias e os riscos que uma testemunha corre ao longo da investigação de um crime ou do próprio processo.

Escutei o depoimento do suspeito até o final. 0 jovem interrogado negava o crime.

Não acompanhei o desfecho da investigação, soube apenas que de fato a mãe da vítima, junto com seu filho mais novo, havia se mudado de bairro.

A história relatada aqui, para além do horror das imagens que evoca e a crueza da narrativa, fala de algo que não está claro: pertence à regra ou à exceção; ocupa ou não um lugar liminar hoje em determinadas periferias de São Paulo? Seria equivocado e falso afirmar que se trata de uma história corriqueira - cabeças cortadas com precisão cirúrgica não fazem parte do cotidiano desses lugares. Além disso, seria como render-se ao óbvio nos dias atuais: o recurso do terror ou das imagens de horror tem sido utilizado em diversas instâncias como ferramenta 
de choque, de mobilização, de construção de um ideário sobre a violência e aos temas associados à ela. É como se, para falar da violência ou de tudo o que ela expressa, o terror fosse uma moldura obrigatória. Por outro lado, os elementos que compõem a história fazem parte de um repertório bastante familiar aos moradores dessas áreas e, portanto, seria igualmente negligente ignorar tal dimensão.

A narrativa fala do homicídio de um jovem, cometido por outros jovens, envolvendo doses maciças e talvez inimagináveis de violência e crueldade. Mas o crime não foi um gesto pontual. Ao contrário, ele tem uma história, além de uma aparente motivação expressa numa combinação entre punição e vingança.

A situação impôs uma série de restrições ao jovem morto; além de ter sido brutalmente torturado, ele deixou de sair de casa por um período, como estratégia para garantir sua sobrevivência. Mas nem isso foi capaz de evitar sua morte. Por quanto tempo, afinal, um jovem pode ficar confinado em casa?

Após o episódio, como havia testemunhado o momento em que o irmão mais velho foi "raptado", o irmão mais novo deixou de ir à escola com medo de que algo the acontecesse. A mãe por sua vez teve coragem de depor e apontar os culpados, como veremos algo pouco usual em circunstâncias como essas, envolvendo conhecidos ou moradores do mesmo bairro. Ela, contudo, tomou tal atitude assumindo a decisão como uma premissa. Afinal, sabia que uma vez a denúncia feita, ela e o filho teriam que mudar de bairro.

O auto-exílio temporário do jovem morto antes de ser capturado, seguido agora por seu irmão que não freqüenta mais a escola e a imposição da mudança de bairro à família, são desfechos também conhecidos em casos semelhantes e deflagram, além do próprio medo e estratégias caseiras de sobrevivência, a noção do desamparo completo da lei, da fragilidade da justiça, deixando claro como ela é muito mais uma idéia, uma aspiração, uma vontade, um refúgio imaginado, mas nunca uma realidade capaz de garantir proteção ou qualquer outra atribuição que lembre aquilo que é formalmente dever do Estado.

Situações como essa envolvendo graus maiores ou menores de violência, anunciadas por diferentes modalidades de criminalidade, compõem um quadro que vem se constituindo e agravando nas últimas décadas em São Paulo.

Compreender a trajetória histórica e social da construção de tal fenômeno é um grande desafio uma vez que os elementos associados ao que hoje é chamado de "violência urbana" são muitos e parecem ter um potencial quase que infinito de criação e reprodutibilidade. Violência por si só é um conceito “escorregadio” que desafia esforços classificatórios, bem 
como qualquer tentativa de definição. Muitas imagens são evocadas pela categoria: cadeias, ciclos, fluxos - a lista pode ser longa e variada, traduzindo o esforço necessário para dar conta da sua dimensão multicausal e da diversidade do conjunto de fenômenos associados a ela.

Este capítulo procura circunscrever o fenômeno em algumas das suas múltiplas dimensões, tomando sua versão local, no caso de São Paulo, sem perder de vista seus significados mais elásticos e abstratos.

A princípio a tarefa de refletir sobre dimensões abstratas da violência parece difícil e um pouco sem sentido, diante dos efeitos tão contundentes que ela tem sido capaz de produzir nos grandes centros urbanos. Mas veremos que o diálogo permanente entre ações e representações faz com que essas não sejam arenas tão distantes.

\section{A configuração de um fenômeno}

Um ponto de partida fundamental para qualquer interpretação acerca da violência é a compreensão do fenômeno na sua escala global. Dados recentes mostram que no ano de 2000 520.000 pessoas foram vítimas de homicídios em todas as regiões do mundo. Estima-se que mais de $90 \%$ das mortes violentas ocorreram em países com renda média ou baixa ${ }^{50}$.

Nesse sentido, a combinação entre o número de mortes, o tipo de conflito e as condições na quais essas mortes ocorreram nos distintos países, ajuda a compor um retrato de seus respectivos cenários políticos, econômicos e sociais.

Não há aleatoriedade na distribuição dos homicídios, suicídios, e acidentes de trânsito ou de vítimas dos conflitos militares nos hemisférios Norte e Sul. A violência, assim como a forma pela qual ela se manifesta é relevante não apenas pela gravidade do fenômeno em si, mas também porque é capaz de "falar" de uma sociedade.

A violência pode referir-se à distribuição de renda num país, mas igualmente às suas relações familiares, ao seu sistema de saúde, à sua disposição para guerra, às suas formas de punição, seus graus de tolerância, seus medos, e uma infinidade de outros temas.

As estatísticas internacionais agrupadas pela Organização Mundial da Saúde permitem atentar com mais clareza para as versões distintas do fenômeno ao redor do mundo. 0 cenário internacional além de sublinhar o caráter constituinte da violência para a humanidade,

\footnotetext{
${ }^{50}$ World Health Organization, 2002a. As escolhas metodológicas das OMS para classificar as regiões por meio da renda serão explicadas a seguir.
} 
mostra também que vivemos numa época particularmente violenta, na qual conflitos fazem parte das dinâmicas de interação entre países, grupos organizados e indivíduos e suas possíveis combinações entre si, agregando uma dimensão transnacional ao debate.

A tabela 1 traz as taxas de homicídios entre os homens, para cada 100 mil habitantes, em diferentes regiões do mundo e sua distribuição pelas faixas etárias. Há uma primeira diferença entre as taxas relativas à população total: os números são significantemente distintos entre as regiões de alta renda onde a taxa é 2.9/100.000 e as de baixa/média que registram 10.1 mortes para cada 100 mil habitantes.

As taxas mais altas, por sua vez, são aquelas dos países de média e baixa renda, sendo a mais alta (89.7) a taxa de homicídios dos países americanos de média e baixa renda, na faixa etária entre 15 a 29 anos.

É interessante notar, contudo, como no Continente Africano, uma região também pobre, os homicídios parecem estar associados a uma dinâmica diferente da porção americana que compreende o Brasil e outros países da América Latina - a América classificada como pobre. As taxas mais elevadas de homicídio na África incidem na faixa etária de 30 a 59 anos.

A concentração das mortes em faixas etárias diferentes sugere que esse tipo de morte nas Américas mais pobres e na África é praticado em contextos diferentes, envolvendo processos sociais diversos entre si.

O dado é importante porque deixa claro não apenas como há uma variedade de manifestações da violência, mas também como um mesmo tipo de manifestação - o homicídio, nesse caso pode ser resultado de processos sociais absolutamente distintos. 
Tabela 1

Taxa de mortalidade estimada provocada por homicídio entre homens - região x por grupo etário

\begin{tabular}{|c|c|c|c|c|c|c|c|c|c|}
\hline Região & Renda & Total & Total & $0-4$ & $5-14$ & $15-29$ & $30-44$ & $45-59$ & $60+$ \\
\hline \multirow[t]{3}{*}{ Todas } & Todas & 8.8 & 13.6 & 5.8 & 2.1 & 19.4 & 18.7 & 14.8 & 13.0 \\
\hline & Alta & 2.9 & 4.3 & 2.2 & 0.7 & 8.4 & 5.5 & 3.3 & 1.9 \\
\hline & $\begin{array}{l}\text { Baixa/ } \\
\text { média }\end{array}$ & 10.1 & 15.6 & 6.1 & 2.3 & 20.9 & 21.3 & 17.9 & 17.3 \\
\hline África & $\begin{array}{l}\text { Baixa/ } \\
\text { média }\end{array}$ & 22.2 & 33.4 & 17.9 & 4.0 & 34.1 & 39.6 & 39.6 & 63.3 \\
\hline \multirow[t]{3}{*}{ Américas } & Todas & 19.3 & 34.7 & 3.5 & 2.4 & 68.6 & 49.1 & 28.9 & 16.4 \\
\hline & Alta & 6.5 & 9.9 & 4.0 & 1.2 & 21.4 & 11.6 & 6.7 & 3.7 \\
\hline & $\begin{array}{l}\text { Baixa/ } \\
\text { média }\end{array}$ & 27.5 & 51.0 & 3.3 & 2.9 & 89.7 & 76.4 & 50.4 & 31.9 \\
\hline $\begin{array}{l}\text { South-east } \\
\text { Àsia }\end{array}$ & $\begin{array}{l}\text { Baixa/ } \\
\text { média }\end{array}$ & 5.8 & 8.1 & 3.9 & 2.2 & 6.0 & 8.8 & 11.6 & 16.9 \\
\hline \multirow[t]{3}{*}{ Europa } & Todas & 8.4 & 13.0 & 1.7 & 0.8 & 15.1 & 23.5 & 18.1 & 9.3 \\
\hline & Alta & 1.0 & 1.4 & 0.9 & 0.3 & 1.7 & 2.1 & 1.6 & 1.1 \\
\hline & $\begin{array}{l}\text { Baixa/ } \\
\text { média }\end{array}$ & 14.8 & 23.2 & 2.2 & 1.2 & 23.9 & 42.6 & 34.8 & 19.7 \\
\hline \multirow{3}{*}{$\begin{array}{l}\text { Eastern } \\
\text { mediterranean }\end{array}$} & Todas & 7.1 & 9.4 & 5.0 & 2.0 & 11.3 & 11.1 & 9.8 & 13.6 \\
\hline & Alta & 4.2 & 6.0 & 1.4 & 0.6 & 10.1 & 9.1 & 4.1 & 5.7 \\
\hline & $\begin{array}{l}\text { Baixa/ } \\
\text { média }\end{array}$ & 7.2 & 9.4 & 5.1 & 2.0 & 11.3 & 11.1 & 1.0 & 13.7 \\
\hline \multirow[t]{3}{*}{$\begin{array}{l}\text { Western } \\
\text { pacific }\end{array}$} & Todas & 3.4 & 5.1 & 1.9 & 1.5 & 7.9 & 7.4 & 4.9 & 3.4 \\
\hline & Alta & 1.1 & 1.3 & 1.1 & 0.5 & 1.5 & 2.0 & 1.5 & 1.1 \\
\hline & $\begin{array}{l}\text { Baixa/ } \\
\text { média }\end{array}$ & 3.8 & 5.6 & 2.0 & 1.5 & 8.6 & 8.0 & 5.5 & 3.9 \\
\hline
\end{tabular}

Fonte: WHO/2002

A Tabela 2 apresenta a distribuição das mortes resultantes de suicídios nas mesmas regiões e faixas etárias. Há uma espécie de inversão dos dados. Nesse caso, as regiões com maior renda concentram as taxas mais altas de mortes dessa natureza. Em países pobres o suicídio parece não ser muito praticado.

Aqui novamente os números nos permitem atentar e questionar o papel da interpessoalidade nas práticas violentas. 0 que os números nos dizem é que os mais pobres não se matam. No entanto, a pergunta imediata, provocada pelos mesmos números, é por que eles se matam uns aos outros. 
Tabela 2

Taxa de mortalidade estimada provocada por suicídio - região x por grupo etário

\begin{tabular}{|l|l|c|c|c|c|c|c|c|c|}
\hline Região & Renda & Total & Total & $\mathbf{0 - 4}$ & $\mathbf{5 - 1 4}$ & $\mathbf{1 5 - 2 9}$ & $\mathbf{3 0 - 4 4}$ & $\mathbf{4 5 - 5 9}$ & $\mathbf{6 0 +}$ \\
\hline Todas & Todas & 14.5 & 18.9 & 0.0 & 1.7 & 15.6 & 21.5 & 28.4 & 44.9 \\
\hline & Alta & 11.4 & 17.7 & 0.0 & 0.8 & 17.0 & 23.6 & 27.9 & 33.8 \\
\hline & $\begin{array}{l}\text { Baixa/ } \\
\text { média }\end{array}$ & 15.5 & 19.5 & 0.0 & 1.8 & 15.4 & 21.1 & 28.6 & 49.2 \\
\hline África & $\begin{array}{l}\text { Baixa/ } \\
\text { média }\end{array}$ & 6.7 & 10,6 & 0.0 & 1.4 & 6.4 & 11.2 & 18.1 & 26.6 \\
\hline Américas & Todas & 8.1 & 13,2 & 0.0 & 0.7 & 13.7 & 17.1 & 18.7 & 26.0 \\
\hline & Alta & 10.6 & 17,4 & 0.0 & 1.2 & 19.9 & 24.1 & 23.8 & 29.9 \\
\hline $\begin{array}{l}\text { South-east } \\
\text { Ásia }\end{array}$ & $\begin{array}{l}\text { Baixa/ } \\
\text { média }\end{array}$ & 6.3 & 10,2 & 0.0 & 0.5 & 11.0 & 12.1 & 13.9 & 21.2 \\
\hline Eaixa/ & 12.0 & 15,7 & 0.0 & 3.1 & 16.9 & 18.5 & 23.3 & 26.1 \\
\hline média & Todas & 19.1 & 32,2 & 0.0 & 1.8 & 30.2 & 46.7 & 52.3 & 51.3 \\
\hline & Alta & 10.5 & 16,4 & 0.0 & 0.4 & 14.8 & 22.6 & 25.1 & 33.2 \\
\hline $\begin{array}{l}\text { Eaixa/ } \\
\text { Média }\end{array}$ & 26.6 & & 0.0 & 2.6 & 40.3 & 68.2 & 79.9 & 74.1 \\
\hline & Todas & 5.9 & 16.4 & 0.0 & 0.8 & 7.6 & 7.5 & 8.5 & 10.8 \\
\hline & Alta & 3.4 & 46.8 & 0.0 & 0.4 & 5.2 & 5.6 & 4.1 & 7.3 \\
\hline $\begin{array}{l}\text { Waixa/ } \\
\text { média }\end{array}$ & 59 & 6.3 & 0.0 & 0.8 & 7.6 & 7.7 & 8.6 & 10.8 \\
\hline & Todas & 20.8 & 4.1 & 0.0 & 1.1 & 14.7 & 19.0 & 28.7 & 69.2 \\
\hline & Alta & 14.3 & 6.4 & 0.0 & 0.7 & 17.1 & 25.8 & 39.7 & 40.7 \\
\hline $\begin{array}{l}\text { Baixa/ } \\
\text { média }\end{array}$ & 22.3 & 21.2 & 0.0 & 1.2 & 14.4 & 18.2 & 26.7 & 76.2 \\
\hline
\end{tabular}

Fonte: $\mathrm{WHO} / 2002$

O Brasil tem em média 7.800 casos anuais de suicídio. 0 Ministério da Saúde registrou uma ampliação dos casos de suicídio desde 1990 de 59,2\%, número que supera o aumento dos homicídios no mesmo período $(55,2 \%)^{51}$.

Os dados de 2004 mostram que, assim como no caso dos homicídios, a faixa etária compreendida entre 15 e 24 anos é a mais vitimizada, tendo observado nesse período um aumento de $57 \%$.

De acordo ainda com os dados do Ministério, do total de suicídios cometidos no país nesse mesmo ano, em $55 \%$ dos casos a vítima tinha menos de 40 anos.

Ainda assim, estamos falando de uma taxa de 4,5 para cada 100 mil habitantes. Um número muito distante da média nacional para os óbitos resultantes de homicídio.

${ }^{51}$ Cerqueira, Daniel; Carvalho, Marceloandre; Lobão, Waldir; Rodrigues, Rute, 2007; D’oliveira, 2005. 
Paremos por aqui, sabendo, contudo, que uma tabela com dados sobre mortes causadas em conflitos de guerra, por exemplo, desenharia um novo mapa das mortes entre as regiões ricas e pobres.

Podemos dizer, portanto, que as mortes causadas por acidentes de trânsito, suicídios, mortes provocadas pelas guerras (internas ou entre países), os homicídios e ainda outros tipos de acidentes, espalhados ao redor do mundo com intensidade variante, contribuem para a construção de uma geopolítica mundial com relevos fundamentais para a compreensão da violência enquanto fenômeno social, mas também como característica do nosso tempo, da nossa sociedade e de cada país ou região do mundo.

Em outras palavras, ao engendrar e traduzir fenômenos sociais, a violência reúne à sua volta signos importantes, capazes de ilustrar os pleitos de uma sociedade, para além daqueles compreendidos no ato violento em si.

0 antropólogo Roberto da Matta argumenta que uma sociedade fala de si quando classifica o que considera violento ${ }^{52}$. Além de falar de si, nesse mesmo sentido, se as versões variadas de violência são ao mesmo tempo produto e produtor de contextos, estabelecendo uma relação circular entre causa e conseqüência, elas também ajudam a construir o inimigo - seja ele o pobre, o terrorista, o jovem, o imigrante, o guerrilheiro civil; assim como as vítimas mulheres, crianças, cidadãos de bem, excluídos, etc.

Com efeito, a morte provocada por causas externas e violentas deve ser compreendida como um fenômeno corrente da geopolítica mundial, em países com níveis distintos de desenvolvimento. Ou seja, ainda que incida de maneira distinta de acordo com faixas etárias, diferentes gêneros e grupos étnicos, não pode ser compreendido como uma manifestação característica de um único país ou região do mundo.

O dado é relevante para evitar, de saída, a associação da violência ou de determinados níveis de violência com uma cultura particular e, consequentemente embaçar a sua compreensão. A tarefa de peneirar as causas e fenômenos associados à ela exige, portanto um ponto de partida amplo.

No Brasil, assim como em outros países da América Latina e Central, a violência tem sua manifestação mais contundente expressa na criminalidade urbana. As estatísticas apresentadas não deixam dúvida quanto ao lugar do país no cenário mundial. Vivemos no país com uma das mais altas taxas de homicídios do mundo.

52 1994a. 
Mas, no caso do Brasil, é preciso atentar para um dado em particular. De acordo com as informações da UNESCO, enquanto a média das taxas de homicídio no país relativas ao conjunto da população permaneceram estáveis entre 1980 e 2002 (o crescimento foi para cada 100.00 habitantes - de 21,3 para 21,7), podemos observar um aumento gritante dos números quando recortamos a faixa etária. Entre os jovens, no mesmo período, as taxas saltaram de 30,0 para 54,5. Isto é, o aumento do número de homicídios nas últimas décadas no Brasil está imediatamente relacionado ao crescimento do número de homicídios contra a juventude ${ }^{53}$.

Com efeito, é possível apontar um protagonista nesse quadro de violência do qual estamos falando: os grandes agentes e vítimas dos homicídios hoje no Brasil são jovens, entre 15 e 24 anos, homens, negros ou pardos, moradores da periferia das grandes $\operatorname{cidades}^{54}$.

O Gráfico 1 mostra a evolução das taxas em três centros urbanos brasileiros (que junto com Vitória no Espírito Santo formam o conjunto das cidades mais violentas do país) tanto para a população total quanto para a população jovem. Revela também como o número acentuado de mortes entre jovens se reproduz ano a ano e em cenários urbanos diferentes.

\section{Gráfico 1 - Comparativos cidades - jovens x população total}

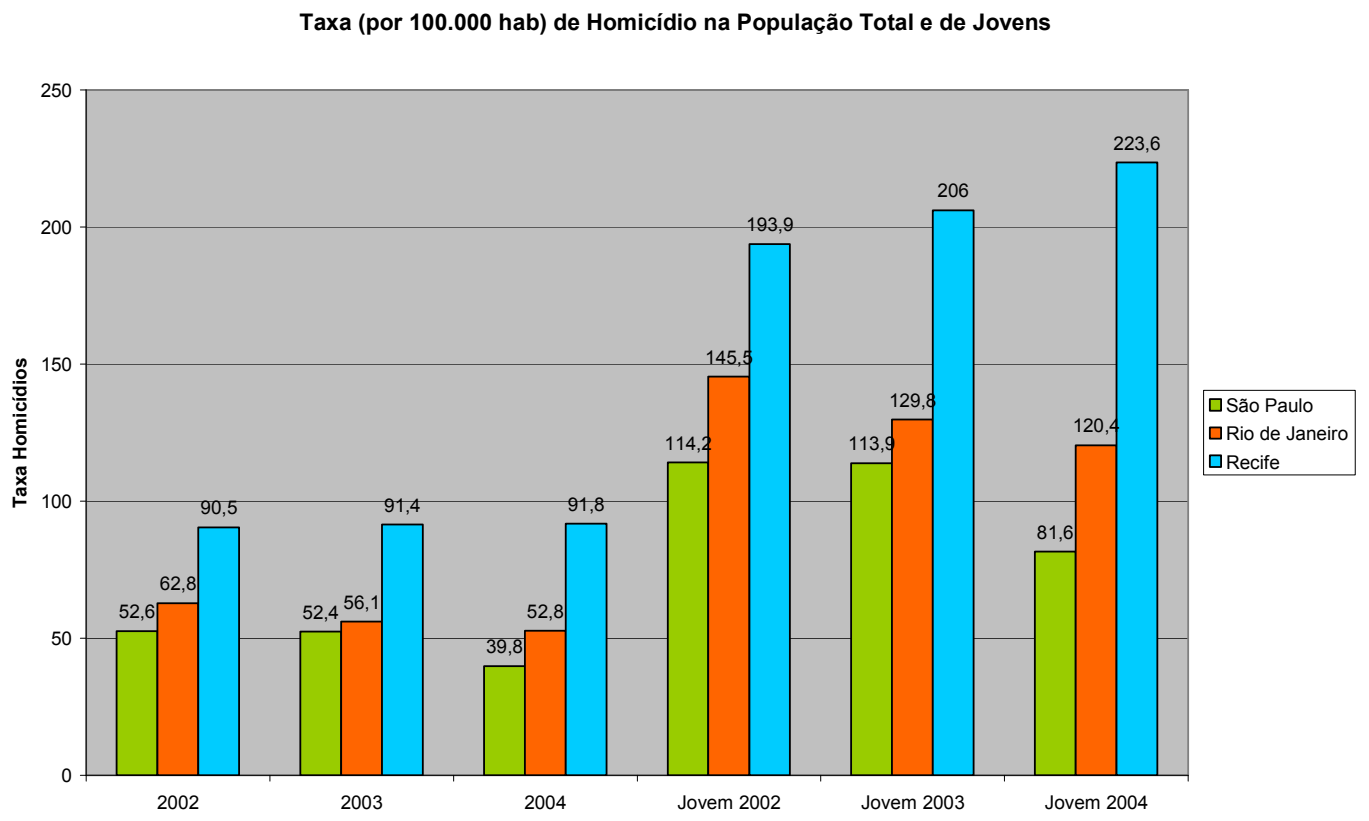

Fonte: Mapa da violência III

\footnotetext{
${ }^{53}$ Waiselfiszs, 2004a.

${ }^{54}$ Idem.
} 
O engajamento dos jovens com os conflitos armados ou com a criminalidade não é privilégio brasileiro. Em “Nem Guerra, nem Paz", Luke Dowdney ${ }^{55}$ faz uma comparação internacional entre grupos organizados de crianças e jovens envolvidos com a violência armada. 0 estudo reúne casos de onze países diferentes ${ }^{56}$, incluindo o Brasil, e pretende, a despeito das diferenças regionais, apontar elementos comuns nas práticas desses grupos, bem como fatores de risco que promoveriam a participação de crianças e jovens em grupos dessa natureza. De acordo com o estudo, a existência de tais grupos explica, ou pelo menos seria responsável, pelos altos índices de homicídios observados na faixa etária entre os 15 e 24 anos.

A etapa brasileira da pesquisa realizou vinte e cinco entrevistas no Rio de Janeiro, procurando reconstruir a história de vida de cada jovem entrevistado, suas motivações para entrar para o mundo do crime, as escolhas, as regras desse universo, seu cotidiano de "trabalho" e as possibilidades de saída.

De maneira geral, os grupos estudados no Brasil foram classificados como "facções territorialmente definidas de traficantes de drogas que dominam comunidades pobres, ou favelas no Rio de Janeiro. Os grupos mencionados são: Comando Vermelho (CV), Terceiro Comando (TC), Terceiro Comando Puro (TCP) e Amigos dos Amigos (ADA)" ${ }^{57}$.

Analisando esse e os outros casos, o estudo menciona três tipos de estruturas organizacionais dos grupos armados: hierarquia militarizada com sistema de postos, estrutura corporativa ou formalmente organizada e, finalmente, uma estrutura horizontal informal que pode ter ramificações descentralizadas.

Por sua vez as formas que essa violência armada pode ser praticada apresentam mais possibilidades classificatórias, manifestando-se nas seguintes formas: 1. disputas territoriais, presentes em todos os grupos estudados; 2. rivalidades não necessariamente ligadas a disputas econômicas ou territoriais; 3. vigilância e execução sumária. Esta última modalidade, por sua vez, pode ser praticada: 4. contra forças do Estado; 5. ser resultado de disputas internas; 6 . ter sua origem em disputas étnicas.

Ainda que o ponto de partida da pesquisa tenha sido as histórias individuais, o modelo que ela apresenta fala da violência como motor e conseqüência da ação de grupos formalmente organizados, com objetivos e estratégias coletivas. Deste modo, é possível nomear tais

\footnotetext{
552005.

56 São eles, além do Brasil: Colômbia, El Salvador, Equador, Honduras, Jamaica, Nigéria, Irlanda do Norte, Filipinas, África do Sul e Estados Unidos.

${ }^{57}$ Idem: 23.
} 
grupos, identificar padrões de atuação e, finalmente, identificar os vínculos causais das mortes violentas entre jovens com esse tipo de prática.

Embora as gangues juvenis apareçam como um ator proeminente no cenário latino-americano envolvendo violência e juventude ${ }^{58}$, como veremos, elas não se mostram como um bom modelo interpretativo para compreender a criminalidade em São Paulo, ainda que, como foi apontado anteriormente, sejam os jovens seus grandes protagonistas.

A literatura clássica que trata de um fenômeno juvenil dos Estados Unidos do começo do século XX no campo das Ciências Sociais, particularmente da Sociologia, elege o tema da desorganização social como grande propulsor da marginalidade juvenil. Nos anos 20 , alguns estudos filiados à "Escola de Chicago" alegavam que a desorganização social do meio ambiente proporcionava um espaço fértil para um rearranjo social onde os laços de solidariedade estariam enfraquecidos e os valores morais degradados. Tal conjunção favorecia ao aparecimento de "gangues juvenis". Essas gangues representavam uma resposta de jovens que viviam em condições desfavoráveis, ou “de risco" como diríamos hoje em dia, que encontravam nessa organização uma forma de sobreviver nesse meio ambiente desfavorável.

De acordo com essa leitura, as gangues representariam essencialmente um processo de comportamento coletivo ${ }^{59}$, cujas principais características seriam: amizade, dependência entre os membros, nítida oposição entre os “de dentro" e os "de fora”. Nesse contexto, a convivência pessoal é o que determinaria a forma de organização social, sempre ressaltando seu aspecto formal, ou seja, suas regras ${ }^{60}$.

Durante muito tempo, tais modelos serviram como moldura para compreender qualquer tipo de manifestação jovem que flertasse com a marginalidade. Hoje, de maneira geral, podemos dizer que as teorias americanas recentes ressaltam aspectos bastante similares, reforçando que as "gangues são coletivos formalizados nos quais o objetivo principal é proporcionar ganhos econômicos e sociais aos seus membros ${ }^{61 "}$.

Ainda que hoje no Brasil, uma parcela jovem da população seja protagonista no movimento da criminalidade nas grandes cidades, os autores em geral observam uma discontinuidade entre os modelos de gangues da literatura norte-americana e os grupos de jovens envolvidos com o crime e a delinqüência no $\mathrm{Brasil}^{62}$. Esse tipo de organização aparece em algumas

\footnotetext{
${ }^{58}$ Rodgers, 1999b, 2003.

59 Thrasher, 1936.

${ }^{60}$ Cohen, 1955.

${ }^{61}$ Spangnol, 2002: 42.

${ }^{62}$ Zaluar, 1997; Spagnol, op.cit.
} 
cidades, como é o caso de Brasília, ou em espaços específicos como a escola ${ }^{63}$. No entanto, em geral, não encontramos gangues, pelo menos não no seu modelo tradicional, quando falamos da criminalidade que assola os grandes centros urbanos brasileiros, em particular dos homicídios.

É possível, por outro lado, pensar em "versões locais" das gangues juvenis. Espalhados pelas grandes cidades brasileiras, encontramos grupos de jovens que, em algum nível estão envolvidos com atividades ligadas à violência ou à marginalidade. Estamos falando dos bandos, galeras, torcidas organizadas ${ }^{64}$ e das quadrilhas. Todas essas formações são compostas por membros jovens que têm suas ações orientadas coletivamente, tal como descrevem os modelos americanos. As motivações e regras que pautam a conduta de tais grupos não remetem, porém, às definições formais das gangues quando pensamos na categoria sociológica.

Mas quando nos restringimos à atividade criminosa onde a morte tem lugar cativo como desfecho, tais modelos interpretativos parecem estar muito mais próximos da realidade carioca e da maneira como o tráfico de drogas se organiza naquela cidade.

Sabemos que no Rio o tráfico de drogas se organiza por meio de grandes empresas, onde é possível identificar uma hierarquia, cargos e papéis mais definidos. É justamente essa hierarquia, ou a ausência dela, que explica muitas das mortes dos jovens nos morros cariocas. Alguns trabalhos conseguem apontar, inclusive, como existem padrões que variam de acordo com a droga comercializada, a proporção do negócio - atacado ou varejo -, a filiação ou não a grupos terroristas, a forma de pagamento, entre uma série de modalidades diferentes possíveis nas práticas do narcotráfico ${ }^{65}$.

Por contraposição, sabe-se muito pouco sobre o tráfico em São Paulo, mas suspeita-se que a sua estrutura não reproduz a espinha dorsal do tráfico carioca. Além disso, alguns dos poucos estudos realizados tratam de drogas específicas como o crack nas regiões centrais da cidade ${ }^{66}$, enquanto outros abordam a perspectiva mais institucional do tráfico e do crime organizado em geral no estado de São Paulo, analisando o papel do Estado, a evolução das apreensões e a participação da polícia nessas redes ${ }^{67}$. Todavia nenhum deles analisa o impacto dessas organizações criminosas na sociabilidade cotidiana das periferias da cidade, ou mesmo a sua ligação com as mortes ocorridas nessas regiões.

\footnotetext{
${ }^{63}$ Abramovay, Rua, 2002.

64 Toledo, 1996.

${ }^{65}$ Zaluar, 2000.

${ }^{66}$ Goulart e Guaracy, 2001; Feffermann, 2006; Paes Manso, 2005a.

${ }^{67}$ Goulart e Guaracy 2001, 2002.
} 
Deste modo, se as investigações cariocas servem como inspiração, sabemos que não é possível usar os mesmos esquemas explicativos.

No caso de São Paulo, como veremos adiante, não é possível limitar as dinâmicas envolvidas nas mortes ao reduto de atuação do tráfico de drogas ou de outras modalidades de crime organizado. Tal ressalva tem como objetivo deslocar o foco da análise de modo a relativizar ${ }^{68}$ o papel do crime organizado em São Paulo, além de esclarecer que o trabalho não pretende tratar esse problema exclusivamente como uma "questão juvenil". A juventude é sem dúvida um dado relevante uma vez, que, seja como vítimas seja como autores os jovens são os grandes protagonistas das ações aqui analisadas. Contudo, o impacto da violência no conjunto de uma comunidade ou da sociedade em geral transborda os limites etários, inclui e atinge outras pessoas além daqueles envolvidos diretamente nos episódios relatados. Nesse sentido, tal dado sugeriu desde o início que a pesquisa não restringisse seu universo de investigação à essa faixa-etária.

\section{São Paulo e o quadro das mortes violentas}

A violência no Brasil, sobretudo aquela associada aos processos de urbanização ou de constituição das cidades, não é um dado novo. Em seu livro "Crime e cotidiano ${ }^{69}$ ", o cientista político e historiador Boris Fausto analisa a criminalidade em São Paulo entre os anos de 1880 e 1924. Ainda que o número de crimes seja extramente inferior ao que encontramos hoje em dia e os tipos de crime ou os instrumentos empregados na perpetração da violência descrevam outros padrões, já naquela época as mudanças vividas pelo cenário urbano parecem ter tido um papel relevante. 0 período foi caracterizado por um crescimento econômico intenso, somado a um aumento da população vivendo nas cidades, que, junto com o processo de imigração, segundo o autor, contribuíram para o processo de transformação da cidade de São Paulo, já em 1924, em um grande e importante centro urbano; o segundo maior do país.

O estudo indica o engajamento de parcelas específicas da população na criminalidade, seja como vítimas, seja como autores. Partindo dos tipos de crime e sua relação com o processo de urbanização e os problemas daí advindos, a pesquisa é capaz de falar da estratificação social na época. Os crimes eram associados à malandragem, aos imigrantes, ou localizados em

\footnotetext{
${ }^{68} \mathrm{O}$ que está por trás da idéia de relativizar aqui não é diminuir a importância do crime organizado, mas abrir espaço para que outros elementos sejam concomitantemente considerados na análise.

${ }^{69}$ Fausto, 2001.
} 
espaços específicos como os cortiços. Tais espaços ou personagens associados ao crime ajudavam a construir um determinado discurso social acerca da criminalidade.

A penalização também aparece como instrumento de controle e de classificação de determinadas classes sociais, traduzindo o processo identificado pelo autor onde a "[...] criminalidade expressa ao mesmo tempo uma relação individual e uma relação social indicativa de padrões de comportamento, de representações e valores sociais ${ }^{70 "}$.

Em larga medida, esse é um argumento que nos ajuda a pensar o cenário contemporâneo.

A violência na condição de tema do cotidiano está presente de forma difusa nas cidades brasileiras e, além da própria violência em si, suas derivações - o medo, a sensação de insegurança e o aparato de proteção particular - para citar alguns exemplos, desempenham um papel importante na caracterização das metrópoles brasileiras.

Sabemos, contudo, que essa suposta dispersão deve ser tratada com cautela. Trata-se sem dúvida de uma temática urbana, muitas vezes comparada a outros problemas da vida nas cidades $^{71}$, tais como a saúde, a educação ou o saneamento. A leitura e compreensão do fenômeno, entretanto, são menos generosas, e associam sem muitas mediações violência e criminalidade violenta à imagem da periferia ${ }^{72}$, privilegiando sua condição de algoz.

Os dados sobre a criminalidade em São Paulo e a geografia das mortes na cidade são, nesse sentido, informações relevantes para delinear um quadro apurado da evolução do crime na cidade, e também, se não, sobretudo, para estabelecer com mais precisão de que tipo de violência estamos falando e quem são, de fato, suas vítimas privilegiadas.

Os homicídios são tomados aqui como um indicador privilegiado da violência urbana. Em primeiro lugar, porque como vimos, estamos falando de números extremamente elevados que desafiam as políticas de segurança pública. No Brasil, os homicídios são os responsáveis pela marcha acelerada da violência letal no país desde a década de 1980. De imediato nos interpelam sobre sua condição de sintoma de uma sociedade que se tornou mais violenta ao longo da sua história recente.

Como esse trabalho vem mostrando, ainda que agrupem motivações de natureza diversa, os homicídios são sempre considerados crimes graves, ou "a ação humana mais uniformemente considerada como crime em diferentes sociedades ${ }^{73}$.

\footnotetext{
${ }^{70}$ Fausto, idem: 27.

${ }^{71}$ Zaluar, 1994b.

${ }^{72}$ Nos termos definidos anteriormente nesse trabalho.

${ }^{73}$ Fausto, op. cit: 107.
} 
"É o crime do homem contra o homem", escutei de um defensor público que atua no tribunal do júri, defendendo acusados como homicidas. A frase expressa o pressuposto de que trata-se de um crime que implica uma relação, algum tipo de interação e sociabilidade entre autor e vítima. $\mathrm{E}$, deste modo, ao mesmo tempo em que dialoga com condições estruturais, carrega, na história de cada crime, histórias particulares, tocando em temas variados seja da biografia do autor e da vítima, seja dos contextos nos quais aconteceram.

Por fim, na medida em que atingem de maneira especial um segmento específico da população e acontecem em sua maioria, em regiões específicas da cidade, os homicídios são ilustrações valiosas da desigualdade com a qual a violência é distribuída nos grandes centros urbanos.

Sua centralidade, todavia, precisa ser associada à ressalva de que os homicídios são um retrato parcial da violência e também um retrato parcial da violência letal. Sua redução não sinaliza, necessariamente que a sociedade tornou-se menos violenta. Indica seguramente, que a violência praticada está menos letal, mas não garante, como veremos a seguir, que ela não venha em doses maiores e mais sofisticadas.

Do ponto de vista metodológico, no Brasil, onde as estatísticas criminais ainda não são uma fonte homogênea no que diz respeito à qualidade de seus dados, o estudo dos homicídios tem sido privilegiado uma vez que esse é o crime que apresenta menos problemas relativos à subnotificação.

Nesse contexto, antes de apresentar os números propriamente, é preciso fazer algumas considerações metodológicas, e quem sabe políticas, a respeito das estatísticas criminais disponíveis.

O uso de estatísticas como fonte de informação e caracterização de fenômenos sociais está associado à idéia de precisão e de objetividade. Nas palavras de Renato Lima, no século XIX, a estatística “[...] vai ganhando espaço como linguagem que organiza o saber científico em torno da quantificação: de ferramentas para a 'arte de governar' a instrumentos de medição da realidade, a estatística serviu ao propósito de quantificação de fatos sociais na tomada de decisão e na constituição de uma tecnologia de interpretação do social ${ }^{74,}$.

Mas, paralela à essa imagem da neutralidade, o autor resume o argumento com precisão quando aponta a necessidade de que interpretações, significados e segredos sejam considerados quando analisamos a produção de dados estatísticos. Ao mesmo tempo em que a transparência da informação é uma das premissas de um ambiente democrático, a produção

\footnotetext{
${ }^{74}$ Lima, 2008, no prelo.
} 
de informação é também objeto de manipulação e pode ser usada para validar discursos, políticas e relações de poder. Com efeito, assim como qualquer tipo de conhecimento, a produção e uso das estatísticas precisa ser problematizada e considerada com cuidado. Talvez ainda com maior atenção, já que nesse caso, sua aparente objetividade é simbolicamente acentuada pela sua tradução numérica.

No interior desse universo, as estatísticas criminais carregam algumas peculiaridades. 0 acesso às informações nesse campo foi, sem dúvida, uma conquista democrática importante. O Estado de São Paulo conta desde 1995 com uma lei que obriga a Secretaria de Segurança Pública a publicar, trimestralmente, as estatísticas criminais do Estado, registradas a partir das ocorrências ${ }^{75}$. A lei permite que além do Poder Público, a sociedade civil acompanhe o comportamento da criminalidade em São Paulo, bem como a própria atividade do Estado e das suas forças policias. Os números divulgados são relativos aos homicídios dolosos, culposos, tentativas de homicídio, lesões corporais, latrocínios, estupros, seqüestros, tráfico de entorpecentes, roubos e furtos, número de armas apreendidas pelas polícias. Além desses casos, também são divulgados os números das seguintes ocorrências envolvendo policiais militares e/ou policiais civis: pessoas mortas ou feridas em confronto com policiais e pessoas mortas e feridas em outras situações que não confronto - especificando se os policiais estavam de folga ou em serviço. São divulgados também o número de policiais, civis e militares, mortos em serviço, mortos em folga, feridos e, finalmente, número de prisões efetuadas pela Polícia Civil e Militar.

Uma vez que a violência e, nesse caso, a criminalidade, são temas centrais e poderosos, é evidente que tais dados além de amplamente divulgados (quando do interesse do Poder Público como no caso da redução dos homicídios), são debatidos pela imprensa e pela sociedade civil organizada, cumprindo sua vocação de informação pública e creditando ao Estado legitimidade e transparência. A divulgação das estatísticas criminais tem hoje uma conotação política e, nesse sentido, o conteúdo da informação é atualmente quase tão importante quanto a sua divulgação.

Esse processo, entretanto, é cercado de tensões. Como veremos, são muitos ainda os problemas técnicos envolvidos na produção desses dados e é questionável o quanto essas informações dialogam com a realidade que reivindicam retratar. De imediato, é possível dizer que não há correspondência entre os avanços tecnológicos e a qualidade final da informação. De acordo com Lima, “[...] parece ocorrer a adoção entusiasmada de sistemas de

\footnotetext{
${ }^{75}$ Lei Estadual Número 9155/95.
} 
geoprocessamento de ocorrência; a disponibilização de processos judiciais na Internet, entre outras iniciativas, sem, contudo, uma avaliação sobre acessibilidade, qualidade, transparência, integridade e utilidade dos dados disponíveis - num movimento que lida com a tecnologia em si mesma e desconsidera processos políticos, classificações adotadas, categorias e conteúdos do fluxo informacional no interior das instituições." ${ }^{76}$

Recentemente as estatísticas criminais foram novamente alvo de controvérsia. A Coordenadoria de Análise e Planejamento da Secretaria de Segurança Pública do Estado de São Paulo (CAP) foi obrigada a refazer a recontagem de 14 tipos de delitos cometidos e registrados em São Paulo desde 2004, incluindo os dados de 2007 até o momento da recontagem ${ }^{77}$. No total, 16 mil ocorrências deixaram de ser contabilizadas. Na nova versão foi confirmada a estimativa inferior não apenas para o os roubos a banco, $89 \%$ de casos a mais do que a versão original, mas também nas ocorrências de roubo de carga (45\%), de veículo (3\%), seqüestro $(8 \%)$ e tentativa de homicídio $(8 \%)$.

Os problemas, de acordo com a Secretaria, resultaram dos registros equivocados dos crimes por parte dos policias quando estes preenchem o boletim de ocorrência. 0 erro dos registros poderia ser interpretado como uma tentativa de "maquiar" os números. As estatísticas, contudo, também foram superestimadas em se tratando de outros tipos de crime como o latrocínio que teve uma queda de $20 \%$ com a recontagem e até mesmo o homicídio doloso que registrou uma queda de $3 \%$.

O erro, aparentemente, não é linear, oscilando para mais ou para menos, o que permite confirmar apenas que ainda é complexa a tarefa de registrar e disponibilizar estatísticas criminais.

Além da polêmica em torno da qualidade dos dados, há ainda um outro obstáculo no que diz respeito à confiabilidade das informações e a sua capacidade de traçar um quadro real sobre a criminalidade em São Paulo: a subnotificação. Uma pesquisa de vitimização realizada pela Fundação SEADE entre 2006 e 2007 (mas não divulgada oficialmente) avaliou que há uma diferença substantiva entre os números de ocorrências registradas e as vítimas declaradas na pesquisa $^{78}$. No caso de alguns tipos de furto ou roubo, a pesquisa indica que metade das ocorrências não é registrada. Em outras palavras, se os dados oficiais reportaram 90 mil

\footnotetext{
${ }^{76}$ Lima, idem.

${ }^{77}$ Em abril de 2007 a Febraban (Federação Brasileira de Bancos) divulgou números de roubo a bancos na capital muito superiores aos publicados trimestralmente pela Secretaria da Segurança Pública. Diante da discordância o então Secretário de Segurança do Estado anunciou a recontagem.

${ }^{78}$ Fontes internas da Fundação atestam a realização de tal pesquisa que foi também noticiada, pelo jornalista Gilberto Dimenstein - Folha de São Paulo, 11.08.2007.
} 
roubos e furtos no segundo trimestre de 2006, devemos ter em mente que os números reais podem chegar a quase 135 mil, deixando um largo contingente de crimes no escuro, ou para a "cifra negra ${ }^{79 "}$.

Junto com o homicídio, outros crimes tais como latrocínio e roubo de carros, sofrem menos com a subnotificação. Em se tratando dos homicídios, os dados nacionais são contabilizados a partir dos registros oficias de óbito, cuja responsabilidade é do Ministério da Saúde ${ }^{80}$. Ainda que o homicídio seja um tipo de crime cuja "cifra negra” ou a subnotificação seja baixa, há, ainda, uma disparidade muito grande entre os dados obtidos junto ao PROAIM ${ }^{81}$ e as Secretarias de Segurança estaduais ${ }^{82}$.

Finalmente, vale lembrar que se do ponto de vista metodológico as taxas e estatísticas são boas e úteis, lidas isoladamente elas são capazes de ocultar outros tipos de violência que podem não ser percebidos ou registrados como tal.

Para efeitos dessa pesquisa, a possibilidade de acessar os dados sobre as mortes violentas no Brasil e no estado de São Paulo mostrou-se essencial para a definição mais precisa do objeto de estudo, para delimitar a sua relevância, estabelecer comparações, subsidiando a própria etnografia. Isso, todavia, não significa que os obstáculos apontados não se apresentaram ou que o uso das estatísticas tenha sido simples. Com efeito, as estatísticas apresentadas a seguir traduzem em parte a fragilidade da condição da informação e indicam como a tarefa de reunir os dados necessários não se resumia apenas a acessar os números disponíveis.

Para ficarmos com alguns exemplos, fontes tidas como igualmente cofiáveis apresentavam números diferentes; não há tampouco homogeneidade nos períodos de informação disponíveis para São Paulo, Brasil e outras unidades da Federação.

Ou ainda, os dados disponíveis em São Paulo são relativos aos distritos administrativos e nunca aos bairros. Desse modo, mesmo que seja possível acompanhar a evolução da taxa de

\footnotetext{
${ }^{79}$ Termo técnico para designar os números que ficam ocultos em função da ausência de registro.

${ }^{80}$ Os dados são registrados no SIM - Sistema de Informação sobre Mortalidade do Ministério da Saúde, criado em 1979. Desde 1973 a lei brasileira prevê que nenhum sepultamento pode ser realizado sem que ocorra o registro do óbito correspondente. As informações do SIM sobre as mortes vêm desse registro, incluindo aquelas que são causadas por armas de fogo, que são divididas em: óbitos por traumatismos acidentais, lesões autoprovocadas intencionalmente, agressões e intenção indeterminada. O SIM permite, além do acompanhamento das séries históricas nacionais, a comparação com os números internacionais produzidos pela Organização Mundial da Saúde. Isso não significa que o SIM também não esteja sujeito a críticas em função das suas limitações ligadas ao subregistro, decorrente dos sepultamentos realizados sem o registro, e da própria abrangência do sistema que não é nacional (Melo Jorge, Gawryszewski, Latorre, 1997).

${ }^{81}$ Programa de Aprimoramento das Informações de Mortalidade do Município de São Paulo.

${ }^{82} \mathrm{O}$ Anuário do Fórum Brasileiro de Segurança Pública mostra como entre os estados da federação há uma diferença na qualidade dos dados.
} 
homicídios no Jardim Ângela, a informação sobre o número de assassinatos cometidos no Parque Novo Santo Amaro não existe ou não é acessível.

Retratar a dificuldade de acesso e uso dos dados é relevante na medida em que, como aponta Lima $^{83}$, ela não pode ser resumida a obstáculos de caráter tecnológico, mas deve ser contabilizada também como uma opção política das instituições de justiça criminal responsáveis pela informação.

Com efeito, o acesso a esses dados deixa de ser apenas um tópico de metodologia para se estabelecer como um elemento fundamental a respeito da conformação do campo epistêmico da violência e da segurança pública, e da própria consolidação da democracia no Brasil.

A seguir são apresentadas estatísticas relativas aos homicídios cometidos em São Paulo no período compreendido entre 1993 e 2005, e gráficos que trazem as taxas por $100 \mathrm{mil}$ habitantes.

Os números apresentados aqui resultam de uma seleção de fontes e períodos disponíveis que fossem capazes de esboçar um quadro da evolução da criminalidade letal em São Paulo ao longo dos anos.

O Gráfico 2 permite uma comparação entre as taxas de homicídios de São Paulo e do Brasil. A comparação é importante na medida em que mostra como São Paulo, seja o Estado, Capital ou a região metropolitana, tem taxas que se destacam no cenário nacional, caracterizando uma região particularmente violenta.

A média brasileira já é alta em relação a outros países, mas o caso de São Paulo é ainda mais notável nesse sentido.

No entanto, os dados do Gráfico 2 mostram também como, diferente da média nacional, as taxas de São Paulo começam a cair a partir de 2000 enquanto que as taxas brasileiras, ainda que permaneçam menores do que as de São Paulo, cresceram de forma sistemática durante o mesmo período.

\footnotetext{
${ }^{83}$ Op. cit.: 5.
} 


\section{Gráfico 2}

Taxa de Óbito por Homicídios na População Total - São Paulo x Brasil

\begin{tabular}{|l|l|l|l|l|l|l|l|l|l|l|l|}
\hline Região & $\mathbf{1 9 9 3}$ & $\mathbf{1 9 9 4}$ & $\mathbf{1 9 9 5}$ & $\mathbf{1 9 9 6}$ & $\mathbf{1 9 9 7}$ & $\mathbf{1 9 9 8}$ & $\mathbf{1 9 9 9}$ & $\mathbf{2 0 0 0}$ & $\mathbf{2 0 0 1}$ & $\mathbf{2 0 0 2}$ & $\mathbf{2 0 0 3}$ \\
\hline SP (UF) & $\mathbf{2 8 , 2}$ & 30,1 & 34,3 & 36,2 & 36,1 & 39,7 & 44,1 & 42,2 & 41,8 & 38,0 & 35,9 \\
\hline SP Cap. & 44,2 & 46,1 & 56,4 & 57,8 & 56,7 & 61,1 & 69,1 & 64,8 & 63,5 & 52,6 & 52,4 \\
\hline RM/SP & 43,3 & 46,6 & 54,3 & 55,8 & 54,6 & 59,2 & 66,4 & 63,3 & 61,9 & 53,6 & 51,1 \\
\hline Brasil & 20,3 & 21,4 & 24,0 & 24,4 & 25,0 & 25,9 & 26,3 & 26,7 & 27,8 & 28,4 & 28,8 \\
\hline
\end{tabular}

Fonte: Mapa da Violência de SP. MS/SVS/DASIS - SIM

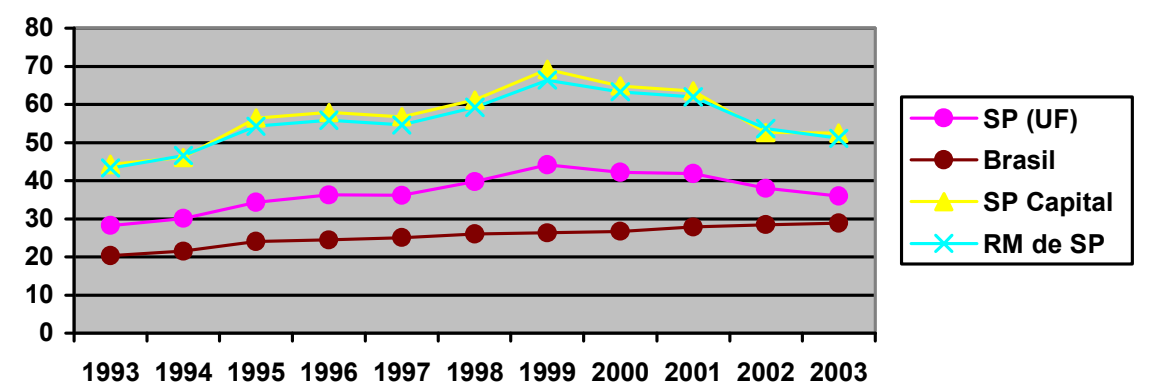

O Gráfico 3 mostra em detalhes as diferenças entre as taxas de homicídios das unidades da Federação. Aqui foram selecionados os estados mais violentos do país. Nesse conjunto São Paulo já aparecia com a menor taxa em $2000(42,0)$ e, ao longo dos quatro anos seguintes também foi o Estado que observou a maior redução nas taxas de óbitos por agressões. Como mostram os dados, a redução, quando ocorre, nos restante dos estados é discreta. No Espírito Santo, por exemplo, a taxa de $2004(49,08)$ é menor do que a dos anos anteriores, mas é maior do que a taxa de 2000 .

\section{Gráfico 3}

Taxa de Óbito por agressão por UF

\begin{tabular}{|l|l|l|l|l|l|}
\hline UF & $\mathbf{2 0 0 0}$ & $\mathbf{2 0 0 1}$ & $\mathbf{2 0 0 2}$ & $\mathbf{2 0 0 3}$ & $\mathbf{2 0 0 4}$ \\
\hline SP & 42,0 & 41,8 & 37,9 & 35,9 & 28,5 \\
\hline RJ & 50,9 & 50,4 & 56,3 & 52,5 & 49,05 \\
\hline ES & 46,2 & 46,0 & 51,3 & 50,1 & 49,08 \\
\hline PE & 54,1 & 58,8 & 54,3 & 55,34 & 50,66 \\
\hline
\end{tabular}

Fonte: NEV/ SIM DATAUS/SEADE 


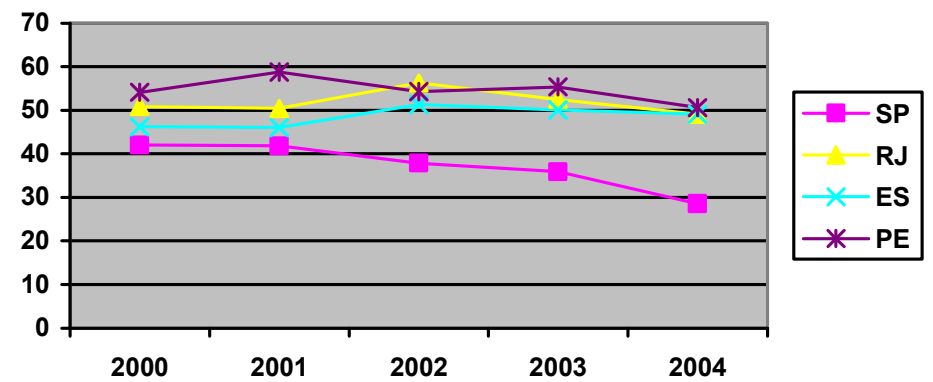

O Gráfico 4 traz as taxas de homicídios para a população total do Estado de São Paulo, para a região metropolitana e para três bairros: Alto de Pinheiros, localizado numa região residencial e rica da cidade, Capão Redondo e Jardim Ângela, ambos na Zona Sul de São Paulo, ambos distritos caracterizados como vulneráveis.

Gráfico 4

Taxa de Óbito por Homicídios na População Total - São Paulo

\begin{tabular}{|l|c|c|c|c|c|c|c|c|c|c|c|}
\hline Região & $\mathbf{1 9 9 5}$ & $\mathbf{1 9 9 6}$ & $\mathbf{1 9 9 7}$ & $\mathbf{1 9 9 8}$ & $\mathbf{1 9 9 9}$ & $\mathbf{2 0 0 0}$ & $\mathbf{2 0 0 1}$ & $\mathbf{2 0 0 2}$ & $\mathbf{2 0 0 3}$ & $\mathbf{2 0 0 4}$ & $\mathbf{2 0 0 5}$ \\
\hline Estado SP & $33, \mathbf{9}$ & 36,6 & 35,6 & 39,0 & $\mathbf{4 3 , 2}$ & $\mathbf{4 2 , 0 3}$ & $\mathbf{4 1 , 7}$ & 39,9 & 35,7 & 28,4 & 21,7 \\
\hline RM/SP & 53,6 & 55,1 & 54,1 & 58,6 & 65,2 & 59,4 & 57,9 & 55,2 & 48,3 & 37,0 & 27,6 \\
\hline A. Pinheiros & 14,6 & 14,8 & 10,7 & 10,9 & 15,4 & 17,97 & 6,8 & 11,4 & 6,9 & 4,7 & 7,1 \\
\hline C. Redondo & 81,0 & $\mathbf{7 9 , 0}$ & 84,7 & $\mathbf{7 3 , 6}$ & $\mathbf{7 9 , 9}$ & 83,63 & 85,8 & 85,8 & 67,0 & 55,96 & 36,5 \\
\hline Jd. Ângela & 112,1 & $\mathbf{9 7 , 7}$ & 90,9 & 102,6 & 115,5 & 118,3 & 99,29 & 99,2 & $\mathbf{8 1 , 1}$ & 64,5 & 43,7 \\
\hline
\end{tabular}

Fonte: Fundação SEADE

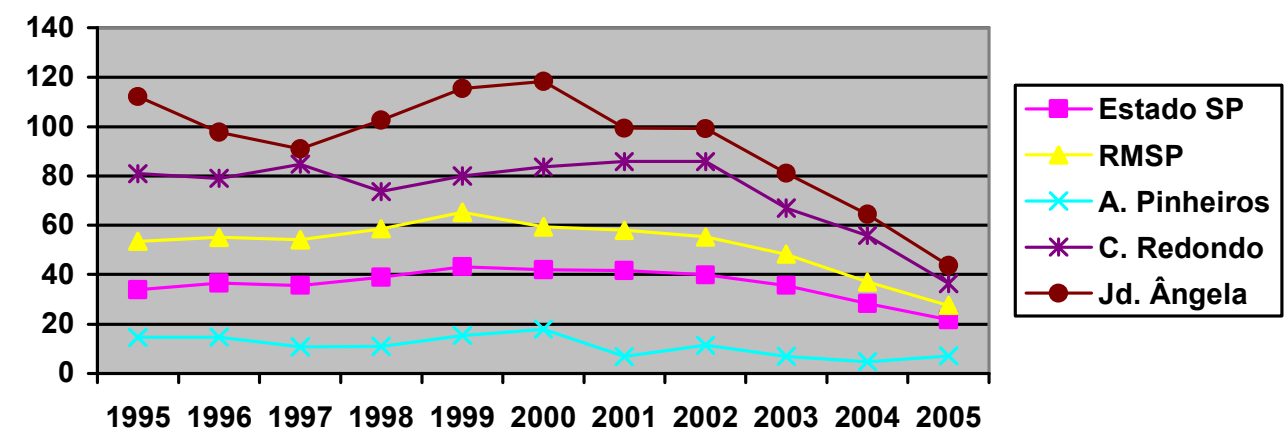

Além do número elevado de mortes como um todo, as taxas revelam, em primeiro lugar, a desproporcionalidade dos números de mortes quando comparamos diferentes regiões da cidade. Há um abismo entre o Jardim Ângela e o bairro de Alto de Pinheiros no que se refere ao número de mortes. 0 risco que um morador do primeiro distrito tem de morrer, mesmo 
com a redução das taxas na cidade como um todo e no próprio Ângela, é mais do que seis vezes maior do que o de um morador de Alto de Pinheiros.

Mas, além disso, o acompanhamento da série histórica revela como, com exceção do Capão Redondo, os homicídios começam a cair em São Paulo a partir de 2001.

Acompanhando a curva decrescente, nota-se como a queda no número de mortes é mais acentuada no Jardim Ângela, mas que, ainda assim, o distrito tinha em 2005 uma taxa $(43,7)$ maior do que a do seu vizinho, o Capão Redondo $(36,5)$, e mais do que duas vezes a do Estado de São Paulo.

\section{Gráfico 5}

Taxa de Óbito por Homicídios na População Jovem - São Paulo

\begin{tabular}{|l|l|l|l|l|l|l|l|l|l|l|l|}
\hline Região & $\mathbf{1 9 9 3}$ & $\mathbf{1 9 9 4}$ & $\mathbf{1 9 9 5}$ & $\mathbf{1 9 9 6}$ & $\mathbf{1 9 9 7}$ & $\mathbf{1 9 9 8}$ & $\mathbf{1 9 9 9}$ & $\mathbf{2 0 0 0}$ & $\mathbf{2 0 0 1}$ & $\mathbf{2 0 0 2}$ & $\mathbf{2 0 0 3}$ \\
\hline SP (UF) & 56,9 & 64,5 & 67,0 & 67,8 & $\mathbf{7 0 , 0}$ & $\mathbf{7 9 , 2}$ & 89,0 & 89,6 & 85,6 & 81,0 & $\mathbf{7 6 , 0}$ \\
\hline SP Cap. & 95,2 & 106,6 & 115,3 & 112,2 & 112,3 & 112,3 & 139,1 & 138,8 & 133,5 & 114,2 & 113,9 \\
\hline RM/SP & 90,5 & 103,5 & 109,1 & 105,9 & 106,3 & 117,0 & 130,5 & 128,1 & 122,0 & 112,5 & 107,7 \\
\hline
\end{tabular}

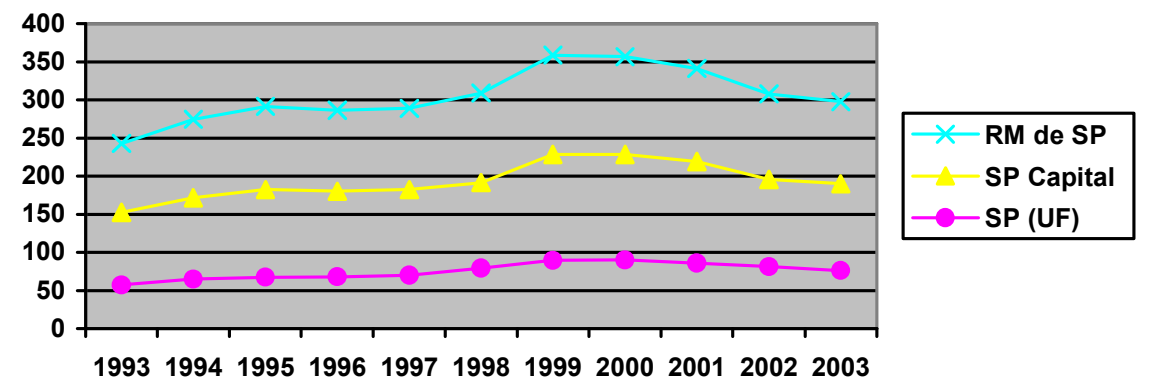

Finalmente, o Gráfico 6 reúne informações dos gráficos anteriores para explicitar um dos argumentos que vem sendo construído ao longo desse trabalho. Parte de um país com taxas elevadas de homicídios, quando comparado a outros países do mundo, São Paulo, a despeito da queda dos homicídios, se destaca como um Estado especialmente violento, tendo como vítimas privilegiadas dessa categoria de violência interpessoal os jovens. A distância entre as curvas dos gráficos deixa explícito o elevado grau de vitimização dos jovens em relação ao restante da população. 
Gráfico 6

Taxa de Óbito por Homicídios na População Total e Jovem - São Paulo x Brasil

\begin{tabular}{|l|l|l|l|l|l|l|l|l|l|l|l|}
\hline Região & $\mathbf{1 9 9 3}$ & $\mathbf{1 9 9 4}$ & $\mathbf{1 9 9 5}$ & $\mathbf{1 9 9 6}$ & $\mathbf{1 9 9 7}$ & $\mathbf{1 9 9 8}$ & $\mathbf{1 9 9 9}$ & $\mathbf{2 0 0 0}$ & $\mathbf{2 0 0 1}$ & $\mathbf{2 0 0 2}$ & $\mathbf{2 0 0 3}$ \\
\hline SP (UF) & $\mathbf{2 8 , 2}$ & 30,1 & 34,3 & 36,2 & 36,1 & 39,7 & $\mathbf{4 4 , 1}$ & 42,2 & 41,8 & 38,0 & 35,9 \\
\hline SP Cap. & 44,2 & 46,1 & 56,4 & 57,8 & 56,7 & 61,1 & 69,1 & 64,8 & 63,5 & 52,6 & 52,4 \\
\hline RM/SP & 43,3 & 46,6 & 54,3 & 55,8 & 54,6 & 59,2 & 66,4 & 63,3 & 61,9 & 53,6 & 51,1 \\
\hline Brasil & 20,3 & 21,4 & 24,0 & 24,4 & 25,0 & 25,9 & 26,3 & 26,7 & 27,8 & 28,4 & 28,8 \\
\hline $\begin{array}{l}\text { SP Cap. } \\
\text { Jovem }\end{array}$ & 95,2 & 106,6 & 115,3 & 112,2 & 112,3 & 112,3 & 139,1 & 138,8 & 133,5 & 114,2 & 113,9 \\
\hline
\end{tabular}

Fonte: Mapa da Violência de SP. MS/SVS/DASIS - SIM

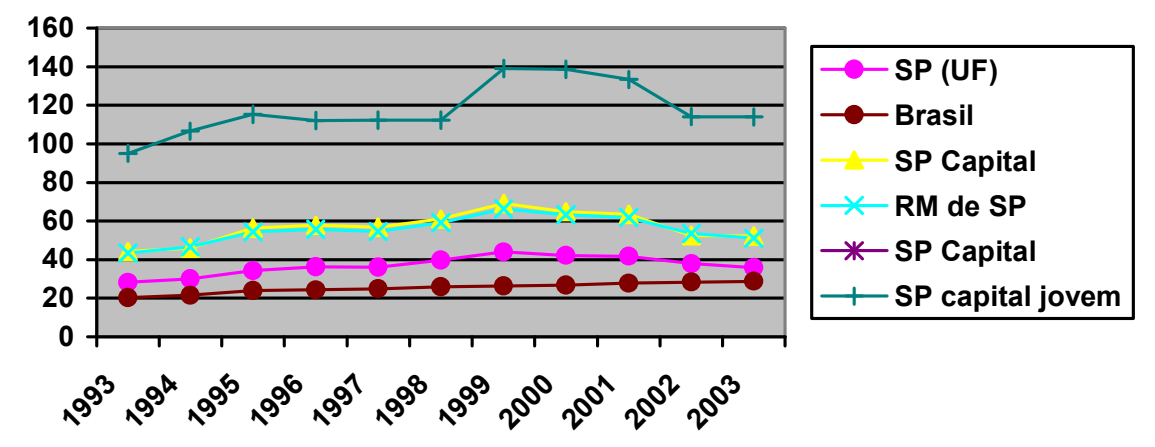

Esses números ajudam a compor um perfil das mortes. Dados como local, faixa etária, e sua evolução são fundamentais para compreender as histórias associadas a esses crimes. Delimitar sua magnitude nos ajuda a acompanhar de que maneira esse tipo de violência foi sendo incorporado à história do país.

\section{Custos da Violência}

A multicausalidade da violência, assim como suas versões matizadas, faz com que suas conseqüências diretas e indiretas sejam percebidas em vários níveis. 0 impacto de um mesmo ato de violência pode ter efeito mais ou menos devastador ou ser percebido de maneira mais ou menos nítida de acordo com a pessoa ou o grupo que inflige e aquele que recebe e é vítima de tal ato.

Desse modo, aquilo que custa a violência para uma pessoa, um país, um governo ou uma comunidade específica compõe uma escala abrangente e variada que reúne um gradiente de custos nas áreas social, econômica, política e até mesmo simbólica. É possível falar desde perda da produtividade de um indivíduo, dos gastos com saúde pública, dos custos legais na esfera da justiça até dos custos morais que significam ter um membro da família preso. 
As questões metodológicas envolvidas no cálculo dos custos, assim como o tipo de informação disponível para tanto são bastante complexas. Alguns estudos trazem exercícios matemáticos que possibilitam calcular, de maneira bastante pragmática e igualmente controversa, o valor de uma vida humana.

Aqui nos interessa menos a dimensão técnica da metodologia e mais as categorias criadas para classificar o que está sendo chamado de "custo da violência".

Em seu relatório intitulado "Economic Dimensions of Interpersonal Violence ${ }^{84 ", ~ a ~ O r g a n i z a c ̧ a ̃ o ~}$ Mundial as Saúde faz uma revisão da literatura mundial disponível sobre o assunto, para, a partir de então, classificar os custos relativos à violência interpessoal, seu impacto global e para cada país analisado. O objetivo primordial do relatório da OMS é comparar custos diretos e indiretos da violência ao redor do mundo com os custos dos programas de prevenção da violência, e mostrar como estes não são apenas mais eficientes, mas também menos onerosos para os Estados.

A OMS identifica dois grupos de custos relacionados à violência:

Custos e benefícios diretos: são os custos de serviços legais, os custos médicos diretos, os custos do controle direto dos perpetradores da violência, de policiamento, encarceramento e abrigo, contratos de segurança privada e os benefícios econômicos dos perpetradores.

Custos indiretos: ganhos e tempo perdidos, investimentos em capital humano perdidos, custos de proteção indireta, custos com seguro de vida, custos envolvidos na garantia da lei, perda de produtividade, de investimento doméstico e externo e advindo do turismo, custos psicológicos e outros custos não-monetários.

Em outras palavras, custos diretos são aqueles relacionados aos bens e serviços públicos ou privados, despendidos na prevenção e tratamento dos efeitos da violência e criminalidade, no sistema de justiça criminal, no sistema penitenciário, nos serviços de atenção social em geral, na saúde pública ou mesmo nos serviços de segurança privada.

Os custos indiretos dizem respeito à perda de investimentos, bens e serviços que deixam de ser produzidos ou arrecadados por conta da criminalidade ou até da sua ameaça, além das perdas que resultam do envolvimento de indivíduos - agressores ou vítimas - com a violência. Ou seja, a conta dos custos deve incluir não apenas os gastos diretamente originados pela violência, mas também aqueles relacionados a comportamentos classificados como de risco e aos problemas de saúde resultantes da exposição à violência.

${ }^{84}$ World Health Organization, 2002b. 
Há um consenso na literatura a respeito da escassez de estudos que tratem dos custos da violência ${ }^{85}$; sobretudo estudos que considerem os efeitos em países de baixa e média renda.

À escassez soma-se o fato de que não há informação disponível e padronizada sobre todos os países e, conseqüentemente, as dificuldades em definir o que pode ou não ser considerado custo da violência faz com que seja difícil calcular com precisão sendo que os valores variam dentro de um mesmo país.

Pfizer $^{86}$ calculou que os custos da violência e criminalidade juntos representam aproximadamente $5 \%$ do Produto Interno Bruto (PIB) dos países industrializados e $14 \%$ do PIB dos países classificados como de baixa-renda. O estudo conduzido pelo Banco Interamericano de Desenvolvimento (BID) calculou o custo da violência para diferentes países e apontou que, em 1997, o Brasil gastou 10\% do seu Produto Interno Bruto com a violência, enquanto El Salvador gastou $24.9 \%$, Peru, $5.1 \%$, a Venezuela $11.8 \%$ e o México apenas $1.3 \%{ }^{87}$.

A literatura reconhece que no que se refere aos custos econômicos, a violência interpessoal impacta de maneira desproporcional países com diferentes rendas, afetando de maneira mais grave os países mais pobres. Isto é, o modo desigual como as mortes se dividem entre as regiões ricas e pobres do mundo está refletido também no impacto e nos custos provocados pelas mortes nessas regiões. A comparação, no entanto, não é simples uma vez que, de maneira inversa, as perdas calculadas para um homicídio são maiores quando falamos dos países ricos, se for levada em conta, especialmente, a renda que o indivíduo deixa de produzir em cada um desses países. Um homicídio pode custar aproximadamente U\$ 15.000 na África do Sul, U\$ 600.000 na Austrália e mais de U\$ 2 milhões nos Estados Unidos ${ }^{88}$.

O Brasil aparece apenas como uma pequena referência no relatório da OMS, mas recentemente o Instituto de Pesquisas Aplicadas (IPEA) desenvolveu um estudo cujo objetivo foi apurar os custos das mortes por causas externas no país.

A pesquisa do IPEA $^{89}$ parte do pressuposto de que cada vítima fatal, - uma morte provocada prematuramente - implica o prejuízo de investimento em capital humano, bem como perda de capacidade produtiva.

O estudo combina a base de dados de renda do IBGE, utilizando a Pesquisa Nacional por Amostras de Domicílio (PNAD) e o Sistema de Informações de Mortalidade (SIM) e a base de

\footnotetext{
${ }^{85}$ World Health Organization, 2004.

${ }^{86} 2001$ et al. World Health Organization, 2004.

${ }^{87}$ Buvinic, Morisson, Shifter, 1999. No caso desse estudo em particular, os autores incluem a violência coletiva nos cálculos.

${ }^{88}$ World Health Organization, op. cit.

${ }^{89}$ Carvalho, Cerqueira, Rodrigues, Lobão, 2007.
} 
dados de óbitos do Ministério da Saúde ${ }^{90}$. A partir do cálculo da renda média anual do trabalho, associada à idade, escolaridade, sexo e domínio geográfico, o estudo avalia para cada registro de óbito no SIM o fluxo médio de renda do trabalho que esse indivíduo teria, caso continuasse vivo durante a sua existência produtiva (considerada aqui entre os 15 e 65 anos).

Colocado de outro modo, o cálculo refere-se ao valor total dos rendimentos que os indivíduos deixaram de receber.

Os resultados finais do estudo calculam que em 2001 o prejuízo total de produção no Brasil, considerando a perda de produção de cada indivíduo morto prematuramente, foi de, aproximadamente, $\mathrm{R} \$ 20,1$ bilhões.

Desagregados, esses números mostram que os homicídios provocaram uma perda de $\mathrm{R} \$ 9,1$ bilhões, os acidentes de transporte $R \$ 5,4$ bilhões e os suicídios $R \$ 1,3$ bilhões.

A média da perda da produção decorrente dos homicídios é maior do que a média provocada pelas outras causas externas analisadas, quais sejam os acidentes de trânsito e os suicídios.

As hipóteses explicativas para o prejuízo mais acentuado no caso dos homicídios apontam para o fato de que esses incidem mais sobre a população masculina, que em geral ganha mais do que as mulheres, com uma reconhecida prevalência entre os mais jovens, que teriam maior capacidade produtiva, e estariam concentrados em áreas urbanas onde os rendimentos são maiores.

Fica claro, portanto, como, para o Brasil, além de uma questão social em múltiplos níveis, e de saúde pública, a violência letal, particularmente as mortes violentas, é também um problema de ordem econômica.

Do ponto de vista das políticas públicas, assim como o combate à fome, à pobreza, às desigualdades de gênero, aos baixos índices de escolaridade e à mortalidade infantil, no debate internacional, a consolidação da segurança foi incorporada como uma etapa fundamental ao desenvolvimento dos países ${ }^{91}$. Nesse sentido, se desigualdade e exclusão não promovem apenas insegurança, mas também criam um terreno fértil para a proliferação da violência, não teríamos como separar os desafios ligados à redução da pobreza daqueles que dizem respeito à prevenção ou redução dos índices de violência.

\footnotetext{
${ }^{90}$ Há, no próprio estudo, um tópico inteiro reservado à uma discussão complexa sobre a metodologia escolhida para calcular tais valores.

${ }^{91}$ Comission on Human Security, 2003.
} 
Com efeito, se não é possível atribuir a violência à pobreza, é possível inverter a relação, localizando-a como um obstáculo ao desenvolvimento e um fator reprodutor de pobreza.

Os custos econômicos associados à violência mostram como ela afasta investimentos, e mostram ainda como os pobres ficam ainda mais pobres, ou deixam de ganhar quando alvo das mortes violentas. Um ciclo perverso parece se estabelecer: se a pobreza enfraquece as redes sociais e cria um campo social fértil para a violência, ao mesmo tempo, a violência se mostra como um determinante relevante de reprodução da pobreza.

Os dados relativos aos custos econômicos contribuem para a construção de um argumento nessa direção. Mas partindo de uma noção mais ampla de desenvolvimento ${ }^{92}$, o desafio reside em conjugar numa mesma equação custos econômicos, políticos, sociais e simbólicos.

Nesse sentido, nos interessa abordar o tema "custos" para pensar a violência uma vez que permite identificar em que campos conceituais e sociais a idéia de custos pode ser formulada. Sem dúvida esse é um dos caminhos para compreender como elementos alocados em diferentes níveis - individual, relacional/interativo, comunitário e social - se articulam na promoção da violência interpessoal.

\section{Armas e Álcool - fatores potencializadores}

No Brasil, entre 1979 e 2003, mais de 550 mil pessoas foram vítimas de mortes provocadas por algum tipo de arma de fogo. Nesse mesmo período, enquanto a população total do país crescia 51,8\%, o número de pessoas vítimas de armas de fogo cresceu $461,8 \%$, sendo os homicídios os responsáveis primordiais por esse aumento ${ }^{93}$.

As estatísticas do DHPP apresentadas mais adiante nesse capítulo corroboram esses números: as armas de fogo foram o objeto empregado em $89 \%$ dos homicídios analisados.

Ainda, como mostrarão os dados do capítulo 3, um número grande de jovens que já estiveram ou estão envolvidos com a criminalidade afirma ter visto uma arma em casa ou declara que seria "muito fácil" conseguir uma arma de fogo se quisessem.

Comparado com outros países, o Brasil desponta como um dos líderes de mortes causadas por armas de fogo. Os números são contundentes: partindo dos dados do DATASUS do Ministério

\footnotetext{
92 No clássico "Desenvolvimento como Liberdade" (2000), o economista indiano Amartya Sen define desenvolvimento como "[...] um processo integrado de expansão de liberdades substantivas interligadas" (:23). O autor menciona tipos distintos de liberdades: liberdades políticas, facilidades econômicas, oportunidades sociais, garantias de transparência, segurança protetora.

${ }^{93}$ Waiselfisz, 2005.
} 
da Saúde referentes a 2002, a médica Luciana Phebo, contabilizou um total de 38 mil mortes provocadas por armas de fogo naquele ano, seja por homicídio, suicídio ou disparos acidentais $^{94}$.

Em números absolutos, esse total supera outros países considerados violentos, como Colômbia, El Salvador e África do Sul. Em relação à população, o Brasil ocupa o $4{ }^{\circ}$ lugar no ranking mundial de mortalidade por projéteis de armas de fogo. No país, o risco de morrer por armas de fogo é 2,6 vezes mais alto do que no restante do mundo, sendo essas mortes em $90 \%$ dos casos homicídios.

A Tabela 3 mostra a marcada prevalência das mortes por arma de fogo entre a população jovem em comparação à população total, e mostra também como a evolução das mortes é maior entre essa faixa etária.

Algumas análises recentes ${ }^{95}$ tentam estabelecer a correlação entre o grande número de armas em circulação no Brasil e os altos índices de violência letal existentes no país. Experiências internacionais tais como as da Austrália e de Bogotá (para citar cenários distintos) mostram que o controle do comércio e a conseqüente redução das armas em circulação resultam na redução das mortes.

\footnotetext{
${ }^{94}$ Phebo, 2005.

${ }^{95}$ Kahan, Zanetic, 2006; Waiselfisz, 2005.
} 
Tabela 3

Mortes causadas por arma de fogo - População total x População jovem

\begin{tabular}{|c|c|c|c|c|c|c|}
\hline Ano & População & Total & & População & Jovem & \\
\hline & $\begin{array}{c}\text { Total de } \\
\text { óbitos }\end{array}$ & $\begin{array}{c}\text { Por Arma } \\
\text { de fogo }\end{array}$ & $\%$ & $\begin{array}{l}\text { Total de } \\
\text { óbitos }\end{array}$ & $\begin{array}{c}\text { Por Arma } \\
\text { de fogo }\end{array}$ & $\%$ \\
\hline 1979 & 711.742 & 6.993 & 1,0 & 28.018 & 2.208 & 7,9 \\
\hline 1980 & 750.727 & 8.710 & 1,2 & 31.986 & 2.924 & 9,1 \\
\hline 1981 & 750.276 & 9.320 & 1,2 & 32.519 & 3.042 & 9,4 \\
\hline 1982 & 741.614 & 9.045 & 1,2 & 32.155 & 2.881 & 9,0 \\
\hline 1983 & 771.203 & 10.830 & 1,4 & 33.168 & 3.449 & 10,4 \\
\hline 1984 & 809.825 & 12.578 & 1,6 & 35.081 & 4.135 & 11,8 \\
\hline 1985 & 788.231 & 13.488 & 1,7 & 35.482 & 4.676 & 13,2 \\
\hline 1986 & 811.556 & 14.869 & 1,8 & 38.504 & 5.244 & 13,6 \\
\hline 1987 & 799.621 & 16.092 & 2,0 & 37.345 & 5.510 & 14,8 \\
\hline 1988 & 834.338 & 17.126 & 2,1 & 37.343 & 6.064 & 16,2 \\
\hline 1989 & 815.774 & 20.440 & 2,5 & 40.411 & 7.672 & 19,0 \\
\hline 1990 & 817.284 & 20.614 & 2,5 & 39.199 & 7.495 & 19,1 \\
\hline 1991 & 803.836 & 21.550 & 2,7 & 38.769 & 7.653 & 19,7 \\
\hline 1992 & 827.652 & 21.086 & 2,5 & 37.509 & 7.193 & 19,2 \\
\hline 1993 & 878.106 & 22.742 & 2,6 & 39.296 & 8.171 & 20,8 \\
\hline 1994 & 887.594 & 24.318 & 2,7 & 41.566 & 8.845 & 21,3 \\
\hline 1995 & 893.877 & 26.763 & 3,0 & 42.932 & 9.694 & 22,6 \\
\hline 1996 & 908.883 & 26.481 & 2,9 & 43.356 & 9.506 & 21,9 \\
\hline 1997 & 903.516 & 27.753 & 3,1 & 44.076 & 10.442 & 23,7 \\
\hline 1998 & 929.023 & 30.181 & 3,2 & 44.664 & 11.574 & 25,9 \\
\hline 1999 & 938.658 & 31.198 & 3,3 & 44.712 & 12.264 & 27,4 \\
\hline 2000 & 946.392 & 43.539 & 4,6 & 45.875 & 17.872 & 39,0 \\
\hline 2001 & 960.614 & 37.090 & 3,9 & 45.808 & 15.075 & 32,9 \\
\hline 2002 & 981.900 & 37.938 & 3,9 & 48.096 & 15.788 & 32,8 \\
\hline 2003 & 1.001 .475 & 39.284 & 3,9 & 47.577 & 16.345 & 34,4 \\
\hline
\end{tabular}

Não são poucos os estudos brasileiros que destacam a proliferação das armas de fogo e o conseqüente acesso facilitado que jovens têm a esse aparato em regiões pobres, como um fator que contribui de maneira determinante para o aumento da violência ${ }^{96}$. No entanto, mesmo diante de números tão incisivos, e da obviedade implícita à relação entre armas e letalidade, não é possível esboçar com precisão os termos em que se dá a interação entre

${ }^{96}$ Entre muitos estudos, podemos citar Peralva, 2000; Soares, Bill, Athayde, 2005; Zaluar, 1999. 
esses dois elementos. As armas não podem ser tomadas como a causa de fundo da violência, mas apenas como um potencializador - poderoso, é claro - da mortalidade dos conflitos.

Sua presença na periferia, contudo, deve ser entendida também como uma manifestação da ilegalidade e seu grau de difusão. A entrada das armas de fogo está conjugada com o tráfico de drogas, com o tráfico e mercado ilegal de armamento e com o fluxo de armas originalmente legais roubadas em outros tipos de crime, que passam a ser ilegais quando desaguadas na periferia. A disponibilidade das armas de fogo, além de aumentar a chance de um desfecho letal para os conflitos, enfatiza a ineficácia da lei e dos mecanismos de controle e regulamentação.

Por sua vez o álcool é uma substância lícita e deve ser tratado de maneira distinta. 0 fato de que seu consumo não é uma prática ilegal, faz com que a interpretação do seu papel na conformação de episódios violentos, assim como a regulamentação dos seus parâmetros de consumo sejam ainda mais complexas.

Kahn e Zanetic $^{97}$ fazem uma revisão da literatura internacional, descrevendo as bebidas alcoólicas, nos termos técnicos, como um elemento “criminógeno" e de que maneira, em se tratando de um contexto já violento, o álcool, assim como as armas de fogo, pode potencializar a violência. Segundo os autores, a influência do álcool pode ser percebida do ponto de vista farmacológico, já que o álcool reduz a capacidade cognitiva dos indivíduos e é, portanto, capaz de aumentar as chances de uma reposta agressiva por parte do sujeito diante de uma provocação. Mas, além disso, o consumo do álcool assim como o comportamento violento podem ser ambos classificados como "comportamento de risco". A literatura internacional sobre o assunto apresenta dados contundentes quando mostra que um alto percentual dos criminosos havia consumido alguma quantidade de álcool no momento do crime.

Os dados brasileiros ${ }^{98}$, ainda que poucos, são também significativos. Um estudo conduzido em Curitiba entre os anos de 1990 e $1995^{99}$, analisou 130 processos de homicídios. As conclusões apontaram que $53,6 \%$ das vítimas e $58,9 \%$ dos autores estavam sob o efeito de bebida alcoólica no momento do crime.

\footnotetext{
${ }^{97} 2006$.

${ }^{98}$ Ainda que não seja objeto desse trabalho, vale notar o aumento vertiginoso do consumo de bebida alcoólica no Brasil: de acordo com a OMS, entre 1970 e 1990 o consumo de bebidas alcoólicas aumentou $74,5 \%$. Soma-se a esse dado o número de adultos que podem ser considerados dependentes do álcool: $11,2 \%$ dos consumidores totais, número que deixa o Brasil n $2^{\circ}$ lugar do ranking de 45 países analisados pela OMS. Já na faixa etária compreendida entre 18 a 24 anos, do sexo masculino, esse número sobe para $26,3 \%$.

${ }^{99}$ Duarte, Carlini-Cotrim, 2000.
} 
Kahn e Zanetic ${ }^{100}$ comentam ainda um estudo realizado pela CAP (Coordenadoria de Análise e Planejamento) da Secretaria de Segurança Pública do Estado de São Paulo e pela Secretaria Estadual de Saúde. Partindo de amostras de 2.714 laudos realizados entre 2001 e 2004 e analisando o resultado do exame toxicológico quando esse foi solicitado para as vítimas (apenas em $45 \%$ dos casos), apurou-se que em 42,5\% dos casos havia presença do álcool entre as vítimas de homicídios. Considerando a dimensão de interação entre vítima e autor, ou a interpessoalidade que caracteriza parte dos homicídios em São Paulo, esse é um dado importante. A condição da vítima pode dar pistas sobre o contexto e local onde foi cometido o crime e até mesmo sobre o autor.

O consumo do álcool está também associado a outras práticas violentas. No município de Diadema onde a "Lei Seca" vigora desde 2002. Além da redução substantiva dos homicídios creditada ao conjunto de políticas desenvolvidas em Diadema pela prefeitura desde 2001 -, pode ser observada a redução também dos crimes de violência contra a mulher.

Fechar os bares como estratégia de prevenção da violência foi uma medida que teve inspiração nos registros das ocorrências dos homicídios no município que indicavam que quase $50 \%$ das mortes aconteciam no período entre $23 \mathrm{~h}$ e $6 \mathrm{~h}$, em vias públicas próximas a bares.

Os dados sobre violência contra mulher são particularmente frágeis no que se refere à sua qualidade $^{101}$, mas na região do $A B C D$, entre os anos de 2003 e 2004, Diadema foi o município que alcançou maior redução dos crimes de lesão corporal, estupro, abuso sexual e ameaça contra a mulher ${ }^{102}$.

Certa ocasião, quando conversava com a delegada da Delegacia da Mulher (DDM) do município sobre os casos recebidos pela DDM, um investigador, que escutava nosso diálogo sentenciou: “Dra. Não é muito bonito, mas também não é muito complicado - menas(sic) pinga menos briga." O que pode parecer uma caricatura simplista, reflete o decréscimo nos números de violência doméstica na região e uma percepção do número e tipo de atendimentos que eram realizados na DDM do município.

É polêmico o debate sobre as razões que fazem com que o álcool seja um elemento que potencialize a violência em determinados contextos e não em outros, uma vez que,

\footnotetext{
${ }^{100}$ Op. cit.

${ }^{101}$ Em função do medo, preconceito, falta de informação, entre muitos outros fatores, a violência contra mulher é um dos crimes com maior grau de subnotificação. "O silêncio é cúmplice da violência" diz o senso comum sobre esses casos

102 Cf. Instituto Sou da Paz, II Plano Municipal de Diadema, 2005: $<$.http://www.soudapaz.org/download/plano diadema.pdf $>$.
} 
isoladamente, ele não possa ser responsabilizado pela violência em nenhuma das suas formas. Mas é preciso considerar os cenários que são palcos dos crimes, aos quais estamos nos referindo. Os bares são uma das poucas opções de lazer na periferia num contexto de extrema escassez de espaços públicos de convivência e de interação entre as pessoas.

\section{Violência e Criminalidade}

Definir o que é violência, seja do ponto de vista teórico, seja a capacidade de reconhecê-la em ação, são tarefas desafiadoras. Da mesma maneira que extremamente contundente quando infligida, ela é também muito fluida e, em vários casos, se faz presente de maneira aguda, mas simultaneamente difusa, assumindo diversas versões, algumas mais fáceis de identificar e nomear do que outras ${ }^{103}$.

De acordo com a definição da Organização Mundial da Saúde, violência é "o uso intencional de força ou de poder físico, na forma real ou de ameaça, contra si mesmo, contra outra pessoa, ou contra um grupo ou comunidade, que resulta, ou tem grandes chances de resultar em ferimentos, morte, danos psicológicos, subdesenvolvimento ou privação ${ }^{104 ” . ~ T r a t a-s e, ~}$ como vemos, de um conceito amplo, versátil o suficiente para classificar um número grande de modalidades - atividade que, nesse caso, parece ser praticada à revelia da própria categoria.

No mesmo relatório a "violência" aparece ainda subdividida em tipos: violência interpessoal, violência auto-infligida e violência coletiva. A violência interpessoal, aquilo que mais se aproxima dos temas que estamos tratando, é definida como a violência praticada entre familiares e parceiros íntimos, violência entre conhecidos ou estranhos que não têm o intuito de promover as intenções de nenhum grupo ou "causa" definida formalmente. A definição exclui, portanto, a violência auto-infligida, guerras ou qualquer tipo de violência promovida pelo Estado ou, ainda, a violência coletiva. Ela compreende, ao mesmo tempo, uma série de subcategorias, tais como: violência contra a criança, contra a mulher, formas de abuso e até violência no trabalho ${ }^{105}$.

\footnotetext{
${ }^{103}$ Podemos tomar como exemplo a violência contra a mulher, contra o idoso e contra a criança - quando acontece no interior da família - que são, por motivos diferentes, mais difíceis de identificar. Os homicídios, ou a violência escolar, em contraposição, são exemplos mais explícitos, de fácil identificação. ${ }^{104}$ Krug, E. et al. 2002, World Heath Organization, 2002b: 30.

${ }^{105}$ World Heath Organization, 2002b.
} 
Muitos outros termos tais como "violência política", "violência institucional" e "violência estrutural" aparecem na literatura, como uma tentativa de estabelecer limites e exercitar as possíveis combinações entre essas modalidades ${ }^{106}$.

No Brasil alguns autores identificam versões nacionais dessa matriz de referência, chamando, por exemplo, de "violência comunitária" - "[...] a violência nas comunidades nas ruas possui um aspecto tipicamente urbano e seus atores fundamentais são a polícia e os jovens. Caracterizada como agressões realizadas contra crianças, adolescentes e jovens em logradouros públicos (ruas, comunidades populares, condomínios, etc.), esse tipo de violência ocorre, em particular, nas periferias dos grandes centros, e tem atualmente como um dos principais motivadores a organização de grupos criminosos armados com domínio de território"107.

A categorização é, sem dúvida, importante. O referencial teórico que identifica e separa os tipos de violência fornece subsídios para que seja possível identificar sua origem e seus agentes, contribuindo, assim, para explicitar suas causas e motivações.

Mas, na verdade, tais fronteiras espaciais são difíceis de delimitar. Na prática, ou quando em ação, as arenas de produção e reprodução da violência parecem ser maiores do que qualquer um desses limites, compreendendo a um mesmo tempo a casa, a rua, a escola, espaços de lazer, o trabalho, etc. É como se a violência fosse tão contundente que estivesse o tempo todo em trânsito, sendo levada de um lugar para outro. Contudo, seria um grave equívoco acreditar que ela está em todos esses lugares. O mais importante parece ser a compreensão de que ela tem potencial para estar em qualquer um desses lugares e isso é relevante na medida em que revela a fragilidade das redes de proteção contra a violência em determinados lugares, e, ao mesmo tempo, é esse potencial o motor para produção do medo e da sensação de insegurança, ambos terrenos férteis para a propagação da própria violência.

Outro aspecto relevante que contribui para a fluidez da violência é a variação dos modos pelos quais ela pode ser percebida. Os graus de tolerância para a violência podem variar e, nesse sentido, é possível encontrar tipos de violência aceitáveis em determinadas situações e reprováveis em outras, ou ainda comportamentos violentos que não são percebidos como tal.

\footnotetext{
${ }^{106}$ Há, ainda, uma ampla literatura no campo da Biologia que trata da temática da violência e de agressividade, privilegiando a dimensão individual. Nos interessa, todavia, como a violência é aprendida no dia-a-dia, os significados que ela ganha quando em ação, em suma, sua condição de fenômenos social. Com efeito, nos parece insuficiente creditar à genética, ou aos hormônios, a configuração de tais fenômenos.

${ }^{107}$ Silva, 2005: 97.
} 
O objeto de investigação privilegiado desse trabalho, o homicídio, está compreendido nessa definição de violência comunitária, mas faz parte daquilo que é chamado de "violência interpessoal". Podem ser ainda classificado como "violência institucional" quando é praticado de maneira ilegítima por agentes do Estado.

Para além da sua dimensão física, o medo e a dinâmica das ameaças imposta pelos homicídios, poderiam ser apontados, ainda, como formas de violência simbólica, mostrando como não é simples a tarefa de estabelecer correspondência entre práticas e categorias.

Alba Zaluar e Sérgio Adorno ${ }^{108}$ fizeram uma revisão extensa e detalhada do tema e do modo como ele vem sendo tratado e interpretado pelos estudos brasileiros. Nesse momento nos interessa apenas caracterizar a violência como fenômeno social e, sendo assim, diferenciá-la da sua definição criminal. Até aqui viemos tratando ambas de maneira indistinta, mas elas não o são. Nem tanto do ponto de vista das práticas, já que no caso dos homicídios o ato é um crime e, ao mesmo tempo, uma manifestação da violência. Mas, como regra, a violência é mais ampla do que a criminalidade. Isto é, ela compreende a criminalidade. 0 que não é verdade se a equação for invertida. O Código Penal prevê inúmeros crimes que não envolvem dose alguma de violência ${ }^{109}$. Com efeito, é preciso compreender o crime como a manifestação jurídica da violência, sem, no entanto, encerrá-la nessa única chave classificatória.

Ainda que a manifestação se dê no campo da criminalidade, como é o caso dos homicídios, o caminho para chegar até lá foi construído numa arena mais ampla do que aquela ditada por seus padrões. Enquanto fenômeno social, a violência pode variar cultural e socialmente; tanto do ponto de vista da percepção quanto da tolerância. Para reconhecê-la é preciso dominar um repertório daquilo que é legal ou ilegal, legítimo ou ilegítimo. Tal questão não aparece de maneira sempre tão explícita, ou mesmo consensuada. Sua leitura exclusiva como crime não comporta tais nuances, tampouco atenta para os processos de construção social desse tipo de desenlace social.

Nos tempos atuais, a violência enquanto tema de reflexão e fato social parece ter sido capturada pelo discurso da criminalidade. Como veremos no capítulo 4, esse entrelaçamento é perigoso, uma vez que, para além da formalidade de categorias, tais classificações acabam delimitando arenas de enfrentamento para os dois: violência e criminalidade -, implicando o

\footnotetext{
108 Zaluar, 1999; Adorno, 2002a.

109 Para o historiador Boris Fausto é preciso fazer ainda uma diferenciação entre crime e criminalidade. Sendo o primeiro um acontecimento que deve ser compreendido na sua singularidade enquanto fenômeno social. O segundo é o fenômeno social na sua dimensão mais ampla que permite, portanto, a observação de padrões a partir das regularidades.
} 
tipo de resposta dada a esses dois fenômenos. A existência da categoria crime, ou a previsão de determinadas condutas no Código Penal, para ficarmos com os termos técnicos, assegura que certos comportamentos não passem despercebidos. Por outro lado, eleger o âmbito penal, não apenas para interpretar o fenômeno, mas também para responder a ele, como parece ter feito nosso Estado e sociedade, exclui dimensões fundamentais para sua compreensão e enfrentamento.

\section{Departamento de Homicídios e Proteção à Pessoa - pistas para a investigação}

Tomar os crimes de homicídios como guias interpretativos para compreender a constituição de novos padrões de violência implica, entre outros, explorar as motivações evocadas nesse tipo de ação. 0 que vem sendo anunciado ao longo desse trabalho é que há uma variedade nas modalidades, bem como de agentes envolvidos nesses processos sociais: o crime organizado, os matadores profissionais, jovens com acesso a armas de fogo, são alguns deles.

Ao mesmo tempo, não há dúvida de que além dos agentes, as motivações por trás dos homicídios se relacionam também ao meio ambiente social, nesse caso caracterizado pela carência material e pela "situação de risco", ou por dimensões estruturais; rótulo sob o qual a literatura sobre o assunto agrupa essas determinantes. Entretanto, como veremos, há também uma dimensão individual em cada um desses crimes. Logo, as particularidades de cada história parecem ser um bom caminho para criar um quadro interpretativo com padrões que contemplem os diversos níveis envolvidos e interligados na produção e prática da violência - sejam eles individuais, coletivos ou estruturais.

O Departamento de Homicídios e Proteção à Pessoa da Polícia Civil de São Paulo (DHPP), partindo de uma análise dos Boletins de Ocorrência provenientes de nove delegacias seccionais de São Paulo, traçou um perfil dos homicídios cometidos na cidade. A pesquisa reúne 576 inquéritos polícias de homicídio doloso, isto é, com intenção de matar, com autoria apurada, correspondentes ao período de $1^{\circ}$ de janeiro a 31 de dezembro de 2003.

A distribuição dos casos entre as Delegacias Seccionais de polícia se apresenta da seguinte maneira: 


\begin{tabular}{ll}
\hline Ocorrência por Seccional & No de casos \\
\hline $6^{\text {a Seccional - Santo Amaro }}$ & 233 \\
$7^{\text {a Seccional - Itaquera }}$ & 108 \\
$4^{\text {a Seccional - Norte }}$ & 79 \\
$8^{\text {a Seccional - São Mateus }}$ & 52 \\
$3^{\text {a }}$ Seccional - Oeste & 48 \\
$2^{\text {a Seccional - Sul }}$ & 26 \\
$1^{\text {a Seccional - Centro }}$ & 19 \\
$5^{\text {a Seccional - Leste }}$ & 10 \\
Itaquaquecetuba & 1 \\
\hline Total geral & 576 \\
\hline Fonte: DHPP/SP &
\end{tabular}

Ainda que esse seja um número tímido diante do volume de mortes em São Paulo, de acordo com o próprio DHPP ${ }^{110}$, entre 2000 e 2005 houve um aumento de 65,5\% no número de esclarecimentos de autoria dos crimes por parte do Departamento. Na capital - a área de atuação do DHPP - os homicídios foram reduzidos em 36\% entre 2000 e 2004.

O Departamento alega que o "Plano de Combate aos homicídios ${ }^{111}$ " em curso desde 2001 tem grande responsabilidade sobre essa queda. Mesmo que não seja possível analisar de maneira precisa o impacto do Plano na queda dos homicídios, é necessário reconhecer alguns números importantes. Entre 2000 e 2004, de acordo com números do próprio DHPP aumentou em 770\% o número de homicidas presos pelo Departamento. 0 número de mandados cumpridos saltou de 165 em 2000 para 1437 em 2004.

Esses são números que mostram mudanças na atividade policial em relação à investigação dos homicídios e nos permitem tratar o universo dos inquéritos considerado aqui como um elemento de maior expressividade.

O número de casos analisados por seccional mostra que, mesmo que estejamos falando de casos ocorridos em toda cidade, somados os casos registrados na Seccional de Santo Amaro e na Sul, as duas mais próximas ao Jardim Ângela, teremos quase $50 \%$ das ocorrências analisadas, configurando uma amostra representativa do perfil de crimes cometidos nessa região, coincidentemente, a região estudada nesse trabalho.

${ }^{110}$ Departamento de homicídios e de proteção à Pessoa (DHPP), 2005.

${ }^{111}$ O Plano previa a integração com a Polícia Militar, identificação e prisão de homicidas contumazes e investimentos nas áreas de tecnologia da informação e inteligência. 
Se tais investigações não esclarecem por completo a motivação que esse trabalho procura nos homicídios estudados, elas podem nos ajudar a delinear pelo menos um perfil, ainda que breve, desses crimes.

De acordo com as ocorrências analisadas, 205 aconteceram aos sábados e domingos, o que equivale a $36 \%$ do total dos homicídios, sendo quase todos à noite: $45 \%$ entre às $18: 00 \mathrm{~h} e$ $23: 59$, ou de madrugada e $28 \%$ das $0: 00$ às $5: 59 \mathrm{~h}$. As armas de fogo foram utilizadas em $89 \%$ dos casos analisados, ou seja, em 512.

Como mostra o gráfico 1, as motivações dos crimes estão distribuídas da seguinte forma: o motivo "vingança" foi atribuído a 164 dos casos, ou seja, 28\%. As drogas são responsáveis por 75 dos casos, correspondendo a 13\% do total. Os chamados "crimes fúteis" respondem por 70 ocorrências ou 12\% dos casos, os “crimes passionais" são responsáveis por $9 \%$ dos casos, 52 ocorrências, aqueles decorrentes de "desavença em bar" ou similar foram atribuídos a 47 casos ou $8 \%$ do total e por fim, 41 crimes, foram motivados por dívida financeira, $7 \%$ do total.

\section{Gráfico 7}

Homicídios - Motivações

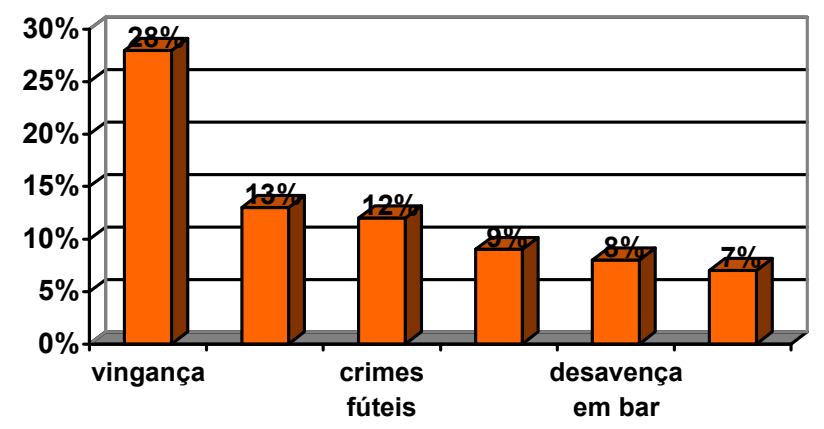

Fonte: DHPP

A tipificação dos crimes como "vingança", "passionais" ou "fúteis" tem como referência o Código Penal. De acordo com os investigadores do DHPP, é a "história de cada crime" compreendida na análise da ocorrência e no processo de investigação - que determina o modo como o homicídio vai ser classificado. Esse, contudo, pode ser um objeto controverso. A classificação "fútil" refere-se às circunstâncias que qualificam formalmente o crime. Além desse, os qualificadores podem ser "paga", "promessa de recompensa” ou motivo torpe. Motivo fútil refere-se a uma motivação de pequena importância, ou que indique desproporcionalidade entre a causa e a gravidade do crime perpetrado, o que não significa que não haja razão para que o crime tenha sido cometido. Vale notar que o ciúme não é 
considerado motivo fútil e a vingança só é lida como fútil se for decorrente de uma agressão também pautada por esta motivação. Em tese, o motivo fútil revelaria maior dolo daquele que o cometeu.

Por oposição, homicídio por "motivo torpe" é aquele que ofende gravemente a moralidade média ou os princípios éticos dominantes de um determinado meio social.

Tais classificações são importantes também para definir a culpabilidade do acusado no momento do julgamento dos crimes. Mas a qualificação não é atribuição do réu. Isto é, não se trata de apurar a leitura feita pelo próprio autor acerca dos motivos que o levaram a cometer o crime, mas a maneira como suas motivações são interpretadas pela lei.

Tomado como uma categoria nativa, "motivo fútil”, diante do quadro descrito pelos números, refere-se aos homicídios banais, resultantes de conflitos do cotidiano. Entretanto, a classificação não permite compreender se motivos aparentemente pouco importantes ou tidos como "desproporcionais" ganham outros significados nesses contextos. Afinal, como qualificar como fútil uma disputa que termina numa morte? Ela pode ser fútil nos termos da lei, mas talvez não para os envolvidos.

Outro problema metodológico reside no fato de que crimes de vingança podem ser também, concomitantemente, crimes passionais, ou vice-versa. Como determinar com precisão a qual categoria corresponde cada um desses delitos?

Não resta dúvida de que esse é um tópico que merece atenção, uma vez que contribui de maneira fundamental para a construção de uma leitura, pelo menos do ponto de vista institucional, sobre a violência na periferia.

Optamos, portanto, em não assumir de saída as motivações indicadas pelo Departamento como a definição categórica das motivações desses crimes. Há uma fragilidade no processo de classificação, na medida em que reconhecidamente ela traduz também a interpretação pessoal do agente que classifica (os investigadores do DHPP), e mesmo que pretensamente balizada pelo Código Penal, carrega doses grandes de subjetividade. Como resultado, não podemos dizer que haja um padrão rígido de classificação das motivações.

Os dados relativos ao entorno, ao contexto, e ao perfil da vítima e do autor, ao contrário, são mais objetivos nesse sentido.

Sobre as vítimas, a pesquisa revela que $91 \%$ eram do sexo masculino, agrupadas na faixa etária entre 18 a 25 anos em 246 dos casos (38\%); entre 26 a 30 anos em 109 das ocorrências e entre 13 a 17 anos em 93 casos. Quase 62\% das vítimas não possuíam antecedentes criminais, 
enquanto $34 \%$ já tinham passagem ou pelo sistema penitenciário, ou pela FEBEM, ou haviam cumprido pena em regime aberto. 0 último dado apresentado pela pesquisa é que $47 \%$ das vítimas estavam desempregadas na época em que o crime aconteceu.

Sobre os autores, os números mostram que esses são também, quase na sua totalidade, do sexo masculino (97\%) a maioria entre 18 e 25 anos (53\%), mas, ao contrário das vítimas, 71,5\% estavam desempregados. Também diferentemente das vítimas $58 \%$ dos autores "possuíam registros de antecedentes no banco de dados criminal da Polícia Civil”, sendo que desse total $36 \%$ estavam cumprindo pena; $19 \%$ dos autores foram identificados como traficantes e $20 \%$ identificados como usuário de substâncias entorpecentes.

\section{Gráfico 8}

Vítimas - Distribuição por faixa etária

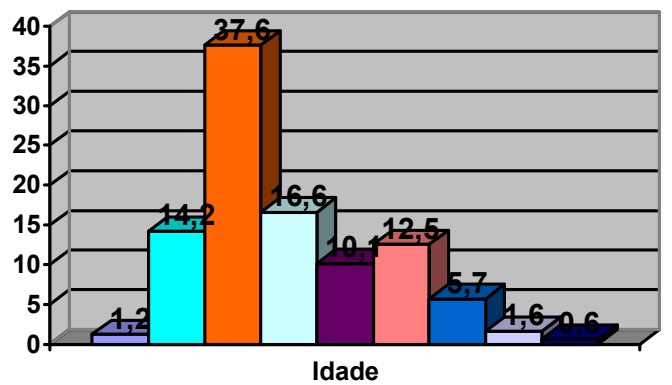

Idade

Fonte: DHPP

\section{Gráfico 9}

Autor - Distribuição por faixa etária

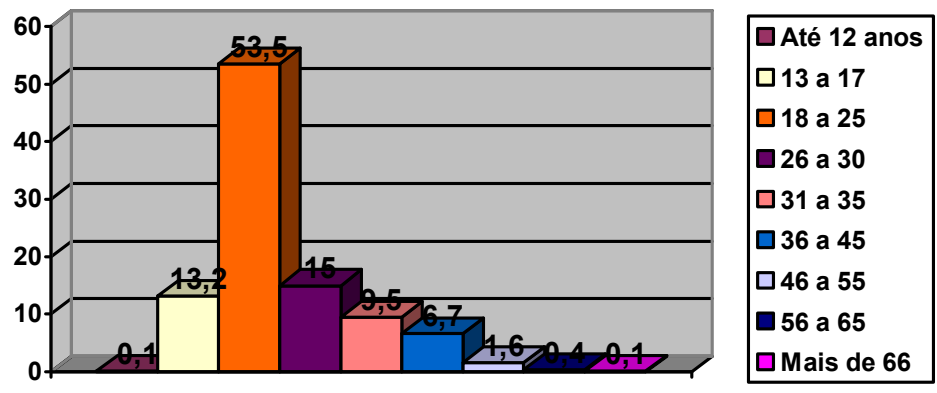

Fonte: DHPP 
Segundo a pesquisa, um número grande de vítimas - 85,5 \% - conhecia seus executores e em 557 casos, (quase todos) essas residiam em locais próximos ao deles e "freqüentavam os mesmo lugares". Isso é reafirmado pelos dados que mostram que mais da metade dos crimes, 252, acontece a não mais de um quilômetro de distância das residências da vítima e do autor e desse total, quase $80 \%$ acontecem a menos de 500 metros.

Ainda que não seja possível reconstruir uma história viva de cada um desses crimes, os números em conjunto dão pistas importantes para pensar em que contexto esses crimes acontecem, as motivações implicadas e de que maneira a morte se configura como um desfecho.

As estatísticas reiteram aquilo que está anunciado no início desse trabalho: estamos nos referindo majoritariamente a homens, entre 18 e 25 anos. Há um grande contingente de desempregados envolvidos nos episódios, especialmente em se tratando dos autores dos crimes. Os números apontam também para uma determinada lógica envolvida na resolução de conflitos.

De maneira geral, os crimes remetem a disputas e confrontos individuais, presentes em qualquer cotidiano e não apenas num cotidiano de exclusão. A singularidade dos casos está assinalada por seu desfecho dramático: há um grande número de brigas em bares, ou conflitos motivados por ciúmes e afins que terminam em mortes. Seu caráter banal e corriqueiro é o que pode fazer com que muitas vezes as mortes sejam atribuídas a um "motivo fútil".

As drogas e os "motivos fúteis" aparecem em proporção semelhante, sendo a "vingança" o motivo atribuído com maior freqüência. Considerando que o DHPP separa os crimes envolvendo "drogas", assumimos que as referidas vinganças não estão relacionadas ao tráfico e que, portanto, se o crime organizado na sua forma de tráfico tem um papel e pode ser responsabilizado por uma parte dessas mortes, tal papel não é o principal.

Finalmente, há diferenças aparentemente fundamentais entre autor e vítima. Os primeiros, de acordo com os números levantados, parecem ter mais ligação com o crime já que têm passagens pela FEBEM ou pelo sistema penitenciário. Os números, infelizmente, não permitem avançar na interpretação. Para tanto, seria preciso conhecer essas pessoas e saber mais de suas histórias de vida.

Estamos lidando com situações onde sugere-se uma relação prévia entre autor e vítima, dado que em muitos casos ambos se conheciam e compartilhavam situações do dia-a-dia e até mesmo de vizinhança. A concentração dos crimes nos finais de semana contribui com essa interpretação. 
Os espaços de convivência e de interação, os finais de semana e horários onde as pessoas estão no seu bairro indicados pelos dados sugerem, num plano mais geral de análise, que tais crimes fazem parte de histórias do cotidiano de seus autores e vítimas. Nesse sentido, cometer um homicídio, além da evidente privatização dos meios de resolução de conflitos, pode ser lido também como parte de um processo de interação entre pessoas. Nesse caso, porém, como se trata de um crime cujo resultado é a morte, um processo dramático de interação entre um autor de um lado e uma vítima de outro. Matar ou praticar a violência parece então se converter numa forma de sociabilidade.

A morte é, claramente, a marca mais contundente do final da vida. Na "sociedade ocidental", ainda que expectativas de vida possam variar entre países e regiões do mundo, a morte prematura, ou a morte que não seja na velhice, é sempre vista como uma exceção.

Mas o perfil dos homicídios em muitas periferias de São Paulo indica que a morte hoje não ocupa necessariamente um momento determinado no nosso ciclo de vida, ou seja, uma marca característica da maturidade. Ela faz parte da vida e é tão comum (e às vezes aleatória) quanto dar a luz, arrumar um emprego ou terminar a escola. Morrer e matar, ao invés de se configurarem como exceções, compõem o padrão de sociabilidade.

Nesse universo, cometer um homicídio pode cumprir múltiplas funções: um acerto de contas associado à criminalidade, uma vingança, uma briga de vizinhos ou uma simples ameaça que precisa ser concretizada. A banalização da morte permite dizer que matar, nesse caso, é também uma maneira de praticar a vida. Ao morrerem assassinados, muitos dos jovens parecem estar cumprindo o seu destino.

A dinâmica de matar ou morrer, no entanto, transborda a relação entre autor e vítima. Como veremos nos próximo capítulo, ela impõe regras de conduta para toda a comunidade, cria uma imagem determinada sobre essas regiões, estabelece representações sobre violência, cria subjetividades e dita uma etiqueta precisa, regida, sobretudo, pela ameaça e pelo medo.

Nas histórias dos jovens pobres, moradores das periferias da cidade, são intermináveis as listas de amigos, parentes ou conhecidos que já morreram. Essa é também uma história de pessoas que, independente da sua proximidade ou distância do "crime", sabem que podem ser ameaçadas a qualquer momento: no ônibus, no salão, na "quebrada" em geral. Ainda que, como diz o senso comum, a morte seja a única certeza da vida, aqui, é como se estivéssemos falando de uma certeza ainda mais provável. 


\section{Variações sobre um mesmo tema - um bar de Diadema e o cachorro do vizinho}

Há uma semelhança muito grande entre os muitos casos envolvendo homicídios recolhidos ao longo da pesquisa. As características eram em geral as mesmas: um conflito corriqueiro, homens, a aparente impossibilidade do diálogo, armas de fogo. Como se fosse possível recombinar elementos em roteiros que se repetiam em cenários distintos.

Assim, um dos casos que me foi contado de maneira informal por um guarda municipal do município de Diadema em 2005, serve como boa ilustração na medida em que reúne elementos importantes para a análise, sendo uma versão de outros casos muito parecidos. A narrativa descrevia uma cena onde dois amigos, ou pelo menos conhecidos, jogavam bilhar num bar. Ao final da partida, ambos se desentenderam e um xingou o outro. 0 "xingado" saiu do bar. Sem pressa, foi até em casa, "buscou uma arma”, nas palavras do guarda, e veio atrás do amigo. Este, por sua vez, correu até a sua casa para se esconder, mas isso não foi suficiente. 0 amigo armado o seguiu até a casa, abriu o portão e disparou dois tiros contra a vítima, que morreu na hora. A cena toda foi presenciada por outras pessoas - como o dono do bar - que, mesmo sabendo do provável desfecho, não fizeram nada para impedir o assassinato.

Imediatamente me lembrei da história muito semelhante que me foi contada por uma liderança comunitária do Capão Redondo naquele mesmo ano. Incomodado com o cachorro da casa ao lado que "latia sem parar", o vizinho, que já tinha reclamado com o dono do animal inúmeras vezes, decidiu ir armado até casa ao lado. Chegando lá acabou se envolvendo numa discussão com o dono do cachorro. A briga só terminou quando o homem armado disparou seu revólver contra o cachorro e também contra seu vizinho, dono do animal.

O desfecho comum quase que antecipado pelo enredo das duas histórias destaca como qualquer outra opção de desenlace - tal como o diálogo, “deixar pra lá”, ter medo da punição que eventualmente seguiria o crime - passam longe de ambas as narrativas. Não há ineditismo na naturalidade com a qual as cenas prosseguiram, na banalidade do conflito, no cenário do bar, na presença do álcool em se tratando da primeira história, na presença de uma arma de fogo, até mesmo na pouca surpresa manifestada pelo guarda em relação ao agravante de que o autor dos disparos tinha uma arma em casa, à sua disposição.

Ao ouvir o relato do guarda, lamento, mas também não me surpreendo. Imediatamente reconstruo a cena em câmera lenta. Imagino o entorno, as pessoas fazendo suas tarefas cotidianas, enquanto alguém "busca" uma arma em casa, persegue a vítima e termina a 
história disparando dois tiros contra ela. Na minha cena imaginada, o resto do cenário não parece ser abalado com o episódio. A vida transcorre normalmente a despeito do homicídio cometido.

Não tenho como saber se a cena de fato se deu da forma como concebi, mas esse não foi o primeiro caso que escutei e a repetição de tantas histórias me leva a pensar - quem sabe equivocadamente - na violência como uma parte integral do dia-a-dia dessas regiões. Nesse sentido, até parece que não é mais possível separá-la de outros fatos corriqueiros do cotidiano.

O próximo capítulo analisa esse tipo de violência em "ação", lançando um olhar mais próximo e detalhado à sua presença e seus efeitos no cotidiano. 


\section{Capítulo 2 \\ Longe do Crime, perto da Violência}

Logo no início da pesquisa fui visitar um bairro também na Zona Sul, mas no distrito do Jardim São Luiz. Estava com dois amigos, um deles morador do local. Caminhávamos pelo bairro enquanto eles me apresentavam o lugar: "aqui era só mato, ali não tinha casa nenhuma, essa praça fica cheia no final de semana [...]". A caminhada seguia quando um deles apontou para a rua acima de onde estávamos para me dizer "mataram um homem ali naquela rua essa semana". E você sabe por que, perguntei. "Porque ele batia na mulher" foi a reposta que obtive.

Ainda que eu não fosse mais uma antropóloga neófita, essa era uma das minhas primeiras incursões a campo desde que havia iniciado oficialmente a pesquisa em questão. A despeito da gravidade do fato relatado, naquele momento tive a impressão de ter tido muita sorte. Em apenas 40 minutos de "campo" eu já estava diante de um caso que retratava a violência na região - o objeto, afinal, que eu estava "à procura". E eu não apenas havia encontrado meu objeto, mas ele mostrava como ela (a violência) não era aleatória. Deixava claro que havia regras, que havia uma moral e que ela deveria ser respeitada, caso contrário a morte aparecia na forma de punição definitiva. Disposta a compreender o universo no qual estava chegando e, como boa antropóloga decodificar suas regras, dei continuidade à conversa, expondo resumidamente minha interpretação aos meus interlocutores. Vocês acham que podemos dizer que ele foi punido porque batia na mulher? Há um tipo de violência que é aceitável, mas bater na mulher, por exemplo, não é? Qual outro tipo não é tolerado? Essas eram apenas algumas das perguntas que eu pretendia responder com esse episódio. Eu não caíra na armadilha mertoniana - não era a anomia que eu havia encontrado, mas a "estrutura social".

Antes que eu pudesse avançar nas minhas interpretações sociológicas de minuto, meus dois cicerones me interromperam rindo, com expressões que misturavam surpresa e uma certa compaixão irônica com minha ingenuidade. 0 homem havia sido morto pelo tráfico de drogas porque batia na mulher, esse era o fato, essa parte eu havia entendido corretamente. Mas não porque os traficantes tinham alguma opinião definitiva e emocionada sobre "bater na mulher", que os alçava a condição de mantenedores da ordem ou garantidores da justiça informal no local. Mas porque o homem fazia isso toda noite, a mulher chorava e gritava e, conseqüentemente, os vizinhos chamavam a polícia. Os traficantes alertaram o homem 
algumas vezes que não queriam saber da polícia ali, mas aparentemente ele ignorou as advertências e seguiu batendo na sua esposa, que continuou chorando, fato que seguiu atraindo a polícia para o local. De forma resumida, o homem foi morto porque sua prática de bater na esposa colocava em risco o negócio dos traficantes.

As regras ocultas, a moral residual ou um vestígio de ordem que eu havia enxergado sumiram imediatamente. Meu modelo interpretativo havia desmoronado em apenas 40 minutos de campo.

Já no carro, voltando para casa depois de ter passado o dia com eles, retomei o episódio, rindo do meu papelão inicial. Aos poucos pude enxergar o acontecido sob uma nova perspectiva, para entender que, na verdade, a história circunscrevia muito bem meu objeto de estudo, caracterizando o fenômeno naquilo que ele tinha de essencial. A morte do homem sublinhava a fluidez entre o estar vivo e estar morto; a opção dos traficantes por matá-lo indicava o pouco medo ou receio de eventuais conseqüências que o ato de matar poderia trazer, assim como demonstrou a impunidade que seguiu o gesto. A morte era também uma presença próxima, seja física - "na rua de cima" - seja na rotina do bairro de maneira geral e aparentemente na vida dos meus amigos. Ao mesmo tempo, não seria correto afirmar que a morte violenta é o que define a vida dos moradores daquela região. A vida dos meus dois interlocutores era infinitamente mais complexa e variada do que o lugar exclusivo de vítimas da violência poderia delimitar.

Morrer nas condições descritas era algo que parecia ter uma constância que oscilava entre o banal - no sentido de que o acontecimento era relatado como corriqueiro - e o trágico, afinal um homem havia sido assassinado. E tal oscilação trazia consigo todas as suas conseqüências: a incerteza, a insegurança e o medo. Era possível reunir num só acontecimento a incapacidade de previsão, o horror e incompreensão (no mínimo da minha parte) das motivações que cercavam o gesto. É como se o sentido de tudo aquilo fosse atribuído somente a posteriori.

Assim, nomear regras parecia uma tarefa impossível. Identificar padrões de comportamento também tinha seu sentido abalado uma vez que o poder das partes envolvidas, aparentemente, era definido em cada relação. O imediatismo das ameaças e o medo contribuíam para dificultar a capacidade de prever desfechos para situações semelhantes.

Mas onde procurar a regra? Porque afinal, se é ela que caracteriza as sociedades complexas, isto é, aqui, na nossa sociedade, nada pode ser creditado ao acaso, era preciso encontrá-la em algum lugar. 
Foi assim, ainda mais inquieta, suspeitando das interpretações imediatamente disponíveis e com esperança de estar um pouco mais "esperta", que passei a enfrentar meu campo, a colecionar histórias e os casos que compõem essa etnografia.

\section{I.À direita na padaria}

0 trajeto pela estrada do M'boi Mirim dura cerca de 40 minutos nos dias em que o trânsito não é tão ruim. Nos finais de semana, percorrer esse mesmo trecho pode levar o dobro do tempo e custar ao motorista muita paciência com carros, ônibus, pedestres, ambulantes e o comércio formal, que disputam o espaço sem fazer muita distinção entre os limites da avenida ou da calçada. A paisagem é intensa e variada. Pequenas concentrações comerciais agregam lojas de móveis, açougues, mercearias, bares, borracharias, lojas de material de construção cercados por muito comércio de rua: camelôs vendendo CD's, roupas, aparelhos eletrônicos, temperos, roupas de baixo, e mais uma infinidade de produtos que não conheço ou não consigo identificar. No percurso, algumas construções chamam atenção: os grandes supermercados, as três igrejas católicas no trajeto, e outras tantas universais e pentecostais que apareciam, sumiam para reaparecerem em lugares diferentes do trajeto durante os anos em que realizei a pesquisa. 0 esqueleto de concreto, um hospital público aparentemente em eterna construção é uma boa imagem e termômetro da relação do poder público com a região. Desde a minha primeira visita ao bairro, as obras foram abandonadas e retomadas de forma intermitente, pelas diferentes administrações públicas, sempre com a promessa de que "agora a construção seria finalizada".

As pinturas reproduzindo uma parede de pedras são um hit local (a estética das falsas paredes de pedra, assim como seu sucesso são fenômenos até hoje inexplicáveis para mim) e decoram as fachadas ao longo do percurso.

Há ainda, ao longo do trajeto, uma seqüência de bases comunitárias da Polícia Militar, outras construções inacabadas, e muita, muita gente andando nas ruas, seja em dias de semana ou seja nos finais de semana. A alternância entre "fachadas" mais adensadas e espaços vazios contribui para a sensação de descontinuidade - quando não há construção na beira da estrada, verdadeiros buracos entre um prédio e outro, entre um aglomerado de casas ou construções, permitem avistar a paisagem da favela ${ }^{112}$, sobretudo do lado direito, e essa se

${ }^{112}$ Em "Planet of Slums" Mike Davis refaz a trajetória histórica da expressão favela, apontando seus
significados variados ao longo do tempo, assim como a capacidade da categoria de mobilizar, além da 
multiplica até o horizonte. À primeira vista é difícil decifrar se estamos num bairro pobre, de classe média-baixa ou de classe média, ou ainda realmente pobre. A paisagem desigual confunde o observador iniciante. Dependendo do pedaço, poderíamos perfeitamente estar no centro da cidade. Avançando alguns metros, no entanto, a paisagem rural, um descampado, um cavalo solto e até uma vaca lembram uma cidade do interior.

O progresso da viagem, contudo, traz mais coerência ao cenário: estamos num bairro pobre, ou pelo menos cada vez mais pobre. Há menos calçadas, menos comércio e o fluxo de carros é mais escasso. Há mais trechos descampados e as construções alternam-se agora entre "barracos" e casas de alvenaria com "puxadinhos", ou com algum outro tipo de complemento agregado indicando sucessivas intervenções - verdadeiros remendos em alguns casos - na obra original. 0 horizonte delimitado por uma paisagem genérica de favelas fica cada vez maior. Estamos definitivamente longe do "centro" da cidade.

O trânsito desregrado parece ser a única constante ao longo da estrada, que nos anos 70, junto com a estrada de Itapecerica e da Baronesa, cortava o cinturão verde que demarcava a área urbana de São Paulo. A reforma promovida pela administração municipal de 2001-2004, da prefeita Marta Suplicy, construiu um corredor de ônibus ao longo da avenida e ampliou as linhas de ônibus e de trem.

A Estrada do M'Boi Mirim pode ser descrita hoje como um grande corredor comercial, uma avenida, responsável pelo acesso a um pedaço grande do que é chamado de Zona Sul de São Paulo. Seu trajeto inteiro atravessa os distritos do Jardim Ângela, Jardim São Luiz e Capão Redondo.

O processo de descentralização administrativa promovido pela gestão municipal de 2001-2004 resultou na criação de novos espaços de gestão pública e, desde 2002, o município de São Paulo está dividido em 31 subprefeituras ${ }^{113}$ (mapa em anexo). Os princípios administrativos e políticos desse novo modelo privilegiam a dimensão territorial do espaço urbano no planejamento e implementação de políticas públicas em campos diversos, apostando na articulação e integração de políticas setoriais. Com autonomia orçamentária, tais instâncias contariam com um planejamento capaz de dialogar com as especificidades do território em

dimensão física, também uma dimensão moral de significado. A definição clássica e operacional que, segundo o autor, foi adotada pelas Nações Unidas em 2002, caracteriza favela pelo "[...] excesso de população, habitações pobres ou informais, acesso inadequado à água potável, e condições sanitárias e insegurança da posse da moradia" (2006: 33). O próprio autor, no entanto, enfatiza a articulação entre a marginalidade econômica e social. Aqui a idéia de "favela" está sendo usada como uma ilustração para uma paisagem urbana que tal qual o que descreve a definição oficial sem, no entanto, desconsiderar a dimensão social e também simbólica evocada pela categoria.

${ }^{113}$ Lei 13.399 . 
particular (ou seja, os distritos que compõem aquela subprefeitura) e, assim, atender às demandas da população local por meio de canais específicos de participação ${ }^{114}$. 0 modelo se opõe a idéia de uma administração centralizada, em tese incapaz de atender de maneira eficaz e justa, as demandas extremamente diversas como as que emergem de uma cidade tão grande e desigual como é o caso de São Paulo.

Hoje as subprefeituras não são homogêneas no que diz respeito ao desempenho das respectivas gestões, tampouco na forma em que correspondem ao projeto original. Grosso modo, são responsáveis por grande parte dos equipamentos públicos da sua região, vigilância sanitária e epidemiológica, limpeza urbana, manutenção do sistema viário, promoção de eventos culturais e esportivos, além de estabelecer canais de participação permanentes, capazes de receber as demandas da população.

Do ponto de vista político, as subprefeituras constituem-se como arenas importantes, espaços de disputa de recursos entre lideranças comunitárias, lideranças religiosas e movimentos sociais em geral. Como resultado, além de uma instância do Poder Público próxima à população, se converteram também num campo fértil para o clientelismo político e para a troca de favores.

Ainda, em relação ao projeto original, as subprefeituras enfrentam uma dificuldade fundamental: numa cidade com as dimensões como as de São Paulo, em alguns casos, elas abrigam distritos administrativos com grandes disparidades entre si como é o caso da subprefeitura de Freguesia do Ó/Brasilândia, na Zona Norte da cidade, que responde pelos distritos de Lajeado e Freguesia do Ó. Os indicadores desses dois distritos caracterizam realidades completamente distintas, o que cria desafios para a implementação de "políticas locais" e impede que a subprefeitura seja tomada como um retrato fiel da realidade daquela região.

Campo Limpo, Capela do Socorro, Cidade Ademar, Ipiranga, Jabaquara, M'boi Mirim, Parelheiros, Santo Amaro e Vila Mariana são as subprefeituras da Zona Sul. A do M’Boi Mirim, responsável não apenas pelo Jardim Ângela, mas também pelo Jardim São Luiz, mais ao norte do distrito, reúne uma área total de $60,1 \mathrm{Km} 2$ e uma população de 484.966 pessoas.

O distrito administrativo Jardim Ângela faz parte dos distritos mais vulneráveis de São Paulo, de acordo com o "Mapa de Vulnerabilidade Social ${ }^{115}$ ". 0 indicador vulnerabilidade social foi desenvolvido pelo Centro de Estudos da Metrópole - CEM/CEBRAP, em parceria com a

\footnotetext{
114 Garibe, Capucci, 2004.

115 Centro de Estudos da Metrópole/CEBRAP, SESC, SAS-PMS, 2004.
} 
Secretaria Municipal de Assistência Social, com o intuito de desenhar um "Mapa da Vulnerabilidade Social da População de São Paulo"116. O Mapa, que faz usos dos dados do Censo Demográfico do IBGE de 2000, reúne variáveis socioeconômicas e demográficas para classificar os setores censitários ${ }^{117}$ da cidade de São Paulo de acordo com o seu grau de vulnerabilidade ou características sociais que possam indicar que uma família é mais ou menos vulnerável ${ }^{118}$. As variáveis consideradas na construção do índice que se associam às duas dimensões abordadas - socioeconômica e demográfica - tratam de questões relativas à educação, renda, idade e estrutura familiar, condições de habitação e gênero. Cada uma das variáveis agrega diversos indicadores e são distintas para os diferentes grupos etários, cercando, a princípio, informações que indiquem ou expressem problemas relativos e específicos de cada faixa etária determinada. No que diz respeito a crianças pequenas, a alfabetização tardia (logo, o percentual de crianças de 5 a 9 anos não alfabetizadas), ou a taxa de internação hospitalar por pneumonia, são indicadores de vulnerabilidade. No caso dos indicadores de risco associados à juventude são considerados o percentual de mães jovens (até 20 anos) no total de mulheres que foram mães em 2001 e a taxa de homicídios entre pessoas de 15 a 29 anos de idade. Ambos, a gravidez precoce, assim como o risco de ser assassinado são apontados pelo Mapa como “[...] dois dos mais importantes fenômenos

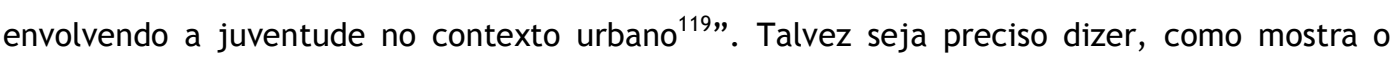
próprio Mapa, que esses são fenômenos e riscos que caracterizam a juventude que vive nas periferias de São Paulo.

Com a formulação do Índice foi possível classificar os diversos setores censitários da cidade de São Paulo, bem como as famílias residentes, conforme sua situação - mais ou menos vulnerável - e, assim, caracterizar mais detalhadamente não apenas a população da metrópole paulista, mas a sua heterogeneidade.

Estudadas as variáveis, realizou-se a análise de cluster, isto é, os setores censitários foram agrupados por características diversas (diferentes combinações possíveis entre a dimensão de

\footnotetext{
${ }^{116}$ Idem.

${ }^{117}$ Os setores censitários são áreas demarcadas pelo IBGE dentro do perímetro urbano, que obedecem a critérios de operacionalização de coleta de dados (abrangem uma área que pode ser percorrida por um único recenseador em um mês, isto é, uma área que possua algo entre 250 a 350 domicílios) Os setores correspondem à menor unidade de informação do censo, o que faz com que a cidade de São Paulo tenha 13.193 setores censitários.

${ }^{118}$ Da maneira como é entendida e utilizada pelo Mapa, "vulnerabilidade" traduz uma combinação de elementos relativos à privação socioeconômica e características demográficas das famílias: "Considera-se que um setor censitário apresenta alta concentração de população vulnerável quando ele apresenta situações de privação expressas por baixos níveis de renda e escolaridade aliados a determinados perfis demográficos - como, por exemplo, a elevada presença de crianças ou de idosos, a expressiva presença de mulheres com baixa escolaridade ou de pessoas muito jovens na condição de chefes de família" (2004: 6).

${ }^{119}$ Ibidem: 22.
} 
privação sócio-econômica e estrutura etária), o que resultou no “Índice de Vulnerabilidade" (IV). O Índice é composto por oito grupos, cada um correspondendo a uma correlação diferente entre as variáveis da dimensão citada e os indicadores relativos às faixas etárias. A partir do Índice produzido, foram criados os seguintes grupos classificatórios: 1. Nenhuma privação; 2. Privação muito baixa; 3. Baixa privação - condições de precariedade socioeconômica médias e presença de famílias idosas; 4. Média-baixa privação - condições de precariedade socioeconômica altas e presença de famílias velhas; 5 . Média privação condições de precariedade socioeconômica médias e com presença de famílias adultas; 6. Alta privação - condições de precariedade socioeconômicas médias e presença de famílias jovens; 7. Alta privação - "condições de precariedade socioeconômicas médias e presença de famílias jovens”'. 8. Altíssima privação

Cada grupo descreve um cenário bastante diverso e a observação do Mapa da cidade de São Paulo ajuda a perceber a grande heterogeneidade daquilo que se chama normalmente de "periferia urbana”. Um setor censitário apresenta alta concentração de população vulnerável quando reúne não apenas uma população com baixos níveis de renda e escolaridade, mas quando tais dados estão associados a determinados perfis demográficos, como a presença de crianças ou de idosos, o que revelaria o grau de autonomia ou dependência de cada membro no interior do conjunto do grupo familiar ${ }^{120}$.

De acordo com o "Mapa da Vulnerabilidade Social”, o Jardim Ângela é qualificado primordialmente pelo grupo de "Alta privação - condições de precariedade socioeconômicas médias e presença de famílias jovens". "Este grupo é formado por 6,0\% dos setores censitários, englobando 7,5\% da população do município. Caracteriza-se pela presença de chefes jovens - idade média de 38 anos, $28 \%$ dos chefes com idade entre 10 e 29 anos - com baixos níveis de rendimento $(67,2 \%$ dos responsáveis pelo domicílio ganham até três salários mínimos) e escolaridade (apenas $25 \%$ dos chefes de família têm ensino fundamental completo). É o segundo pior grupo nos indicadores de renda e escolaridade. Neste grupo observa-se o menor percentual de chefes mulheres, $21,5 \%$, sendo que $18,5 \%$ delas possuem até oito anos de escolaridade, no máximo"121.

Alguns setores localizados no interior do distrito têm características de outros grupos do Mapa e constituem "ilhas" envoltas pela área caracterizada pelo grupo de Alta Privação e Jovens. As mais relevantes, no entanto, são mesmo as classificadas pelo Índice de Vulnerabilidade

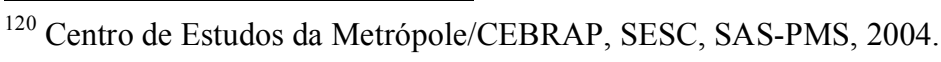

${ }^{121}$ Idem.
} 
como sendo caracterizadas pelos grupos: “Alta privação" - condições de precariedade socioeconômicas altas e presença de famílias adultas e “Altíssima privação”.

O Índice de Vulnerabilidade Juvenil (IVJ), outro indicador que sintetiza um conjunto de variáveis para indicadores baseados em variáveis sócio-econômicas foi criado como referência na formulação exclusiva de políticas públicas para essa parcela da população.

O IVJ considera em sua composição “[...] níveis de crescimento populacional e a presença de jovens entre a população distrital, freqüência à escola, gravidez e violência entre os jovens e adolescentes residentes no local ${ }^{122}$ ". Ou seja, reúne as estatísticas sobre fatores considerados relevantes num cenário de risco juvenil: deficiências educacionais, mortes por homicídios e maternidade na adolescência. Este indicador varia em uma escala de 0 a 100 pontos, em que o zero representa o distrito com menor vulnerabilidade e 100 o de maior.

Na sua primeira versão de 2002, o IVJ trazia dados dos 96 distritos administrativos de São Paulo, e junto com o Grajaú, o Jardim Ângela ocupava a $4^{\mathrm{a}}$ posição no ranking dos distritos mais vulneráveis, fazendo parte do "grupo 5", com 65 ou mais pontos na escala de vulnerabilidade.

A taxa de mortalidade por homicídio da população masculina de 15 a 19 anos utilizada no cálculo da versão de 2002 do IVJ para o distrito, era de assustadoras 438,2 mortes para cada 100 mil habitantes. No mesmo ano, a taxa de São Paulo para a população total era de 64,8 , do Brasil, 47,2, e de Pinheiros, 21,8. ${ }^{123}$

Na sua versão atual, lançada em 2007, a elaboração do Índice reorganizou a divisão territorial da cidade e, ao invés de trabalhar com distritos, separou as áreas de acordo com a seguinte classificação: 1. Áreas pobres; 2. Áreas de classe média baixa; 3. Áreas de classe média e; 4. Áreas ricas ${ }^{124}$, como mostra o Mapa 1. A área pobre reúne 19 distritos administrativos, localizados na sua totalidade nas regiões mais periféricas da cidade ${ }^{125}$. A reunião desses distritos agregava, em 2005, 31,4\% dos paulistanos, sendo que desse total, 8,9 eram jovens.

\footnotetext{
${ }^{122}$ Fundação SEADE, 2002.

${ }^{123}$ Waiselfisz, Athias, 2005.

${ }^{124}$ Os aspectos metodológicos da caracterização dessas regiões como pobres ou ricas estão explicados de maneira detalhada no próprio documento do IVJ. Sem abandonar a dimensão política da escolha de determinadas variáveis para caracterizar a condição vulnerável, o uso do indicador de vulnerabilidade cumpre aqui o objetivo de fazer um retrato de determinadas regiões e sublinhar a desigualdade entre regiões de São Paulo a partir de categorias que nos interessam.

125 São elas: Anhanguera, Brasilândia Campo Limpo, Campão Redondo, Cidade Tiradentes, Grajaú, Guaianazes, Iguatemi, Itaim Paulista, Jardim Ângela, Jardim, Helena, Jardim São Luiz, Marsilac, Parelheiros, Pedreira, Perus, São Rafael, Vila Curuçá, Lajeado.
} 
A redução dos homicídios em São Paulo a partir de 1999, apontada no capítulo anterior, provocou uma conseqüente redução no IVJ de uma maneira geral, uma vez que essa era uma das estatísticas consideradas no cálculo do Índice. Mas não apenas isso. Diante de uma redução generalizada da vulnerabilidade entre os jovens na cidade de São Paulo, o Índice observa a maior redução nas áreas consideradas pobres. De acordo com a análise feita na construção do indicador, o aumento da freqüência ao ensino médio entre jovens de 15 a 17 anos foi o principal responsável pela redução nos índices de vulnerabilidade. Tal dado é seguido pela redução nas taxas de mortes entre jovens de 15 a 19 anos e a diminuição da evasão escolar entre jovens de 15 a 17 anos. A taxa de fecundidade entre adolescentes parece ter uma importância menor na redução verificada.

\section{Mapa 1}

Fonte:IVJ/Fundação SEADE

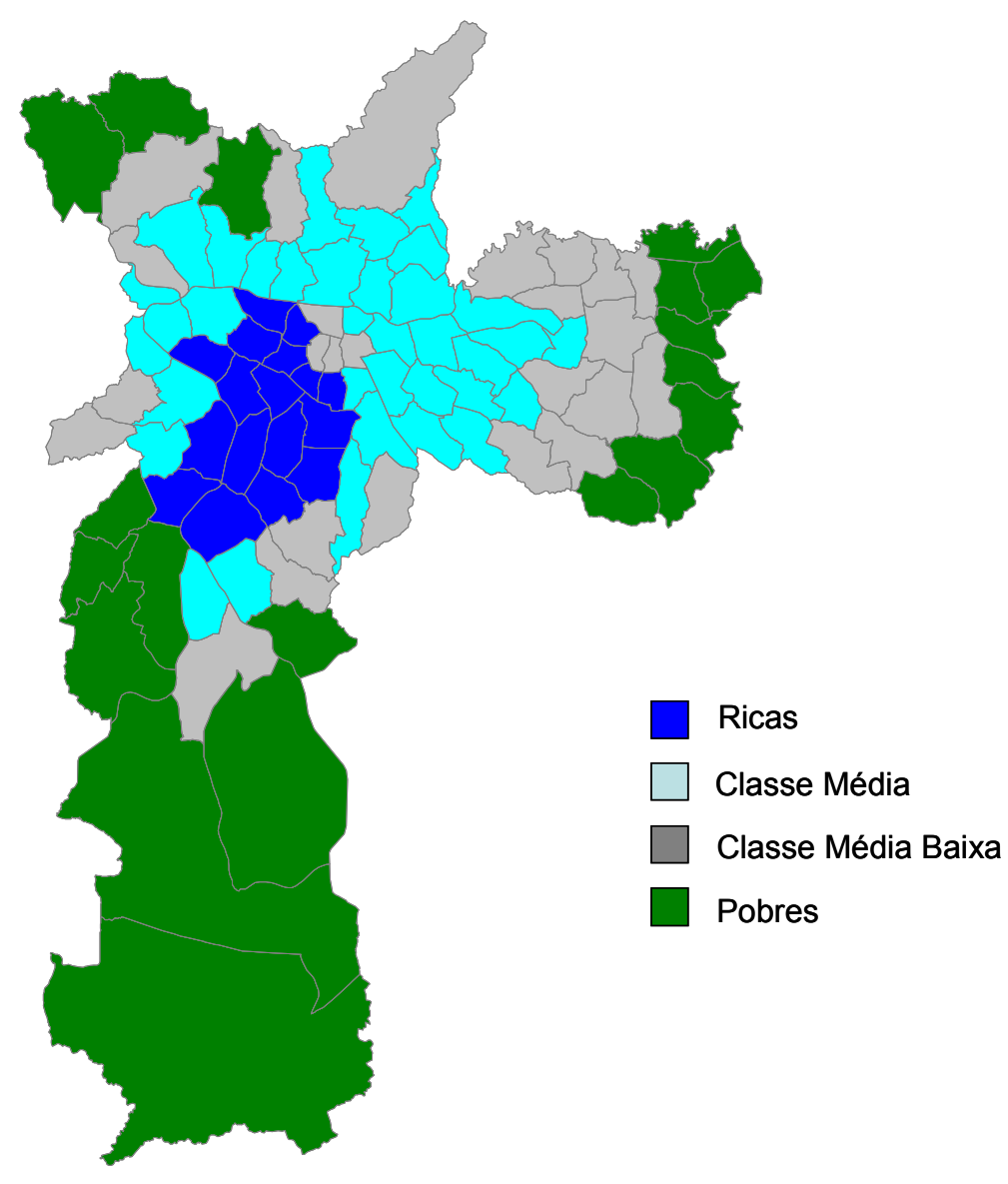


No entanto, acompanhando a redução do IVJ nas diferentes áreas desagregando os componentes temos os seguintes dados: a taxa de mortalidade por agressão entre homens de 15 a 19 anos para o município de São Paulo é de cinco pontos. Nas áreas ricas ela é zero, nas áreas de classe média três, média baixa cinco e nas áreas pobres alcança oito pontos. Observando os outros componentes do indicador (tabela 1), é possível notar que, não por acaso, é o indicador que trata de violência que retrata a maior disparidade entre as áreas ricas e pobres.

\section{Tabela 1}

Redução do IVJ por tipo de Área, segundo Componentes Município de São Paulo

2000/2005

\begin{tabular}{lccccc}
\hline Componentes & $\begin{array}{c}\text { Município } \\
\text { de SP }\end{array}$ & Rica & $\begin{array}{c}\text { Classe } \\
\text { Média }\end{array}$ & $\begin{array}{c}\text { Média } \\
\text { baixa }\end{array}$ & Pobre \\
\hline Taxa de fecundidade & 2 & 0 & 0 & 2 & 4 \\
$\begin{array}{l}\text { Taxa de mortalidade por agressões de } \\
\text { homens de } 15 \text { a } 19 \text { anos }\end{array}$ & 5 & 0 & 3 & 5 & 8 \\
$\begin{array}{l}\text { Proporção de jovens de } 15 \text { a } 17 \text { anos } \\
\text { que não freqüentam a escola }\end{array}$ & 4 & 5 & 4 & 6 & 4 \\
$\begin{array}{l}\text { Proporção de jovens de 15 a 17 anos } \\
\text { que não freqüentam o ensino médio }\end{array}$ & 8 & 6 & 6 & 10 & 8 \\
\hline Total & 19 & 11 & 13 & 23 & 24 \\
\hline
\end{tabular}

Fonte: Fundação Seade/ IV] 2007

Sobre tais diferenças o IVJ observa que, a despeito da redução generalizada, os riscos ainda permanecem mais elevados para os jovens moradores das regiões mais pobres. Logo, se São Paulo celebra a redução de homicídios no Estado, não podemos deixar de assinalar que há uma manutenção do padrão espacial da mortalidade. Em outras palavras, esse tipo de violência segue vitimizando primordialmente as periferias da cidade que parecem não se beneficiar da mesma forma das políticas públicas disponíveis para combatê-la.

As taxas de mortalidade por agressão para essa faixa em 1999/2001 eram para a área rica 56,7 e para a área pobre 303,0. Em 2005 esses números eram respectivamente 57,1 e 184,4.

Os mapas 1 e 2 mostram como as manchas que indicam a incidência de homicídios estão menos concentradas na cidade como um todo, enfatizando sua presença na Zona Sul. Mas o que as manchas deixam claro também é que a concentração territorial permanece. 
A falta de dados mais precisos é ainda problemática num outro sentido. Ainda que seja possível acompanhar por meio da evolução das taxas de homicídios a queda de mortes no Jardim Ângela, não é possível saber de que maneira ela se distribui pelo distrito. Nesse sentido, ela pode reproduzir a desigualdade observada entre as regiões pobres e ricas da cidade no interior do próprio distrito. Isto é, algumas regiões do Jardim Ângela podem ainda estar sofrendo com os mesmo padrões de violência anteriores, sem que tal fato seja vislumbrado pelos números.

A incapacidade de um diagnóstico preciso acerca das causas da redução dos homicídios em São Paulo contribui para que seja impossível isolar variáveis e, assim, fazer um mapeamento mais preciso do próprio distrito.

A heterogeneidade na manifestação de fenômenos sociais num território aparentemente homogêneo, do ponto de vista da sua caracterização sócio-demográfica, foi apontada numa pesquisa recente desenvolvida também pelo Centro de Estudos da Metrópole (CEM). No caso do estudo realizado pelo CEM, além de assinalar a variedade daquilo que é comumente classificado como "periferia”, a pesquisa foi capaz de revelar "situações de pobreza” variadas no interior de um mesmo território. Para dimensionar essas muitas versões da pobreza, o estudo considerou as características dos grupos sociais, combinando variáveis associadas à renda, escolaridade, taxa de desemprego, infra-estrutura urbana, presença de negros e pardos, entre outras. A partir dos dados desagregados, foi possível fazer uma discrição detalhada da distribuição de tais grupos sociais e de suas condições de vida ${ }^{126}$.

Eleger o território como referência, teve ainda uma outra conseqüência: o estudo também aponta elementos que podem ser determinantes na reprodução da pobreza, tais como padrões de vizinhança, acesso a equipamentos públicos, etc. e como eles podem impactar de maneira distinta, grupos que vivem em situações que, a princípio, seriam classificadas da mesma forma.

${ }^{126}$ Marques, Torres, 2005: 59. 


\section{Mapas 2 e 3}

Fonte:IVJ/Fundação SEADE
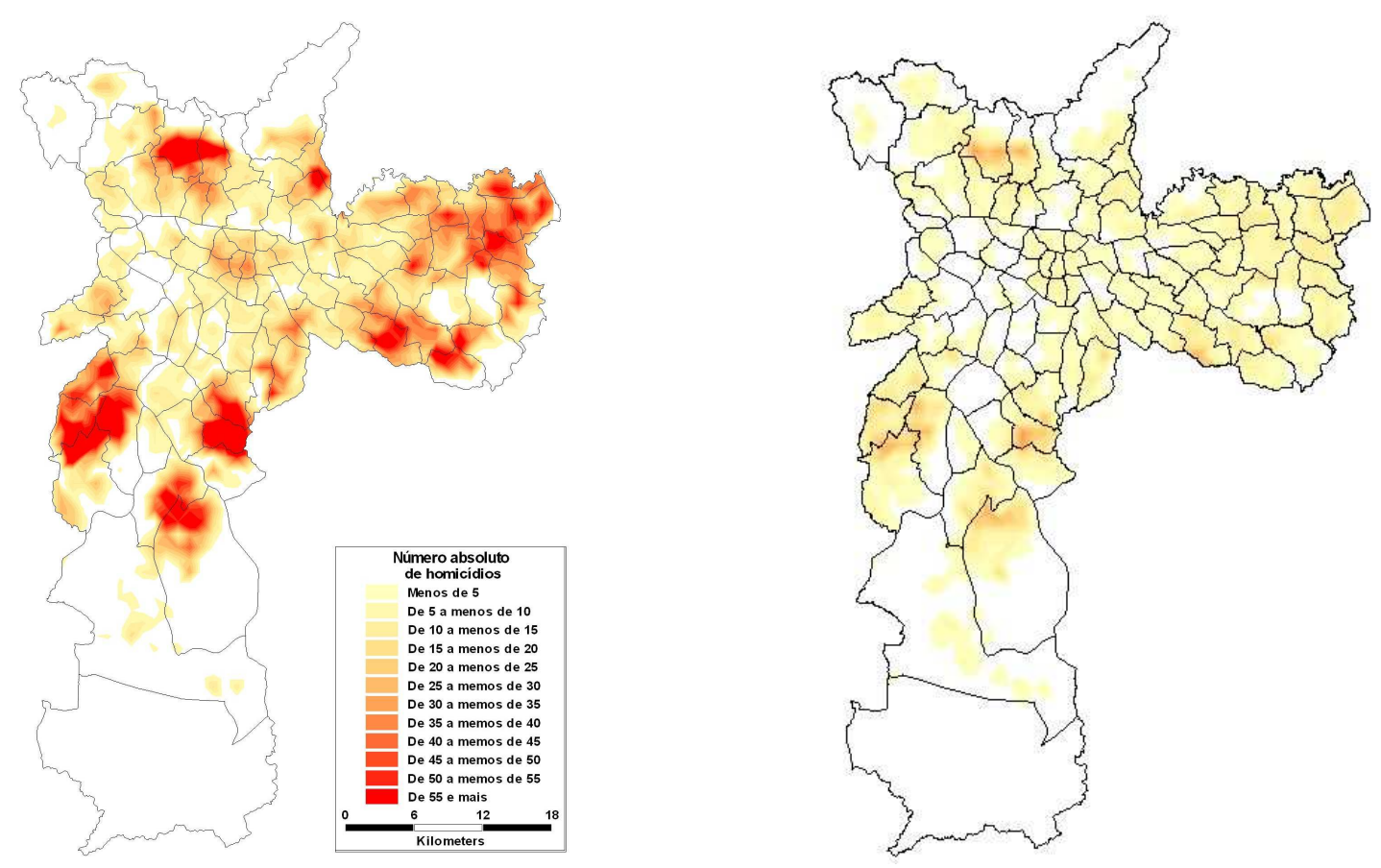

\section{II, Fazendo história na violência}

A despeito da redução observada pela versão mais recente do IVJ, podemos dizer que ambos, o “Mapa da Vulnerabilidade” o “Índice de Vulnerabilidade Juvenil” retratam o Jardim Ângela como um distrito marcado por privações de caráter social, econômico e cultural associadas a grandes doses de violência, sobretudo de crimes contra a vida.

0 distrito tem hoje $37,4 \mathrm{~km} 2$, onde habitam quase 300 mil pessoas. A área tem uma alta taxa de crescimento populacional (a população do distrito cresceu 32\% entre 1991 e 1999, ao passo que, no mesmo período, a população do município de São Paulo cresceu apenas 3\%) com grande concentração de crianças e jovens, como mostra o gráfico 2. 


\section{Gráfico 2}

Distribuição da População por Faixa Etária - Jardim Ângela 2006

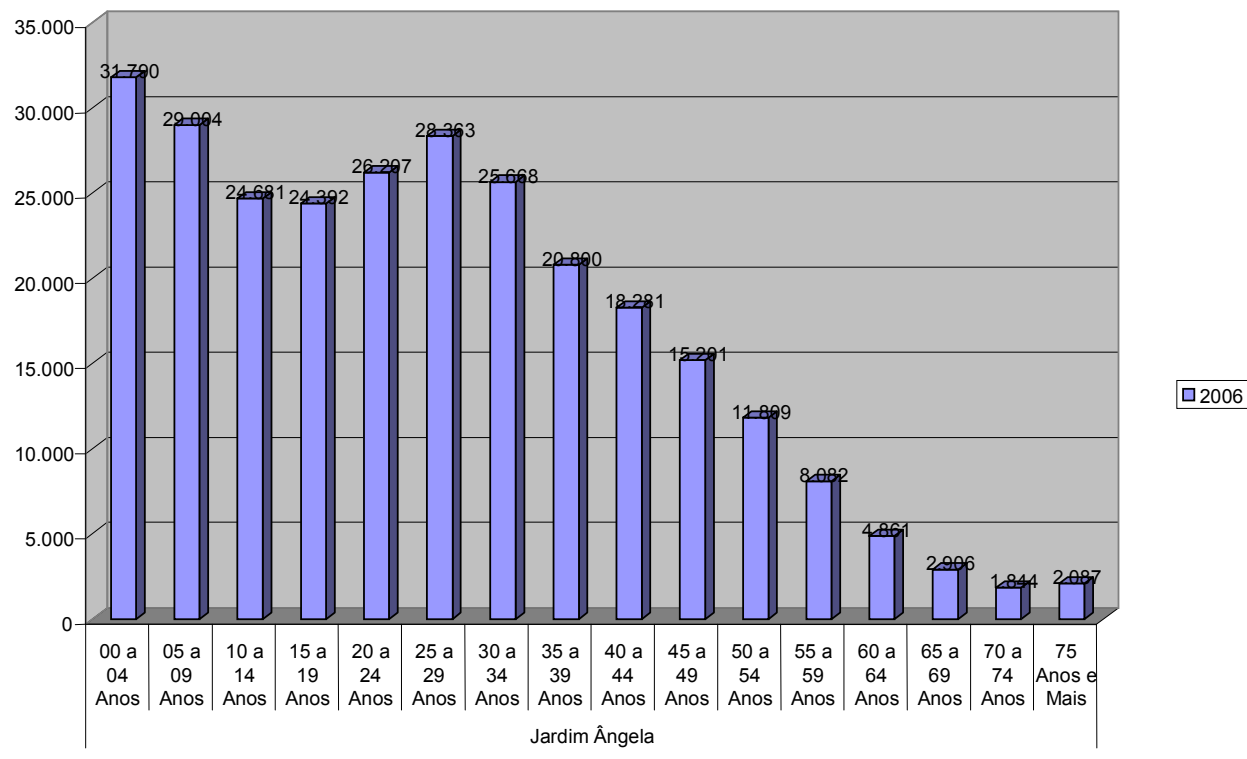

Fonte:Fundação SEADE

A maior parte da população $(22,02 \%)$ tem renda média na faixa de 3 a 5 salários mínimos, mas como mostra o gráfico 3, quase a mesma proporção de pessoas responsáveis por domicílios $(19,83 \%)$ não tem rendimento algum. As taxas de baixa escolaridade da população em geral e o alto número de adolescentes com filhos ou grávidas, ajudam a compor a perfil sóciodemográfico do distrito.

A Zona Sul de São Paulo, mas particularmente o distrito do Jardim Ângela, ficou mundialmente conhecido quando em 1995 foi diagnosticada pela Organização das Nações Unidas Nações (ONU) como uma das regiões mais violentas e perigosas do mundo. A imprensa nacional explorou à exaustão tal referência e o bairro tornou-se um símbolo privilegiado da criminalidade urbana que crescia e assustava o país. Ganhar as páginas dos jornais fez com que a violência, até então confinada à essa região periférica, encontrasse não apenas espaço na mídia, mas também chamasse a atenção de Organizações Não-governamentais e do Poder 
Público. A partir de 1999, uma série variada de ações, projetos sociais, políticas na área da prevenção à violência passaram a ser desenvolvidas na região. Na época, a taxa de homicídio local era de 111,52 para cada 100.000 habitantes ${ }^{127}$. Esse número não se destacava apenas em comparação com outros distritos do município; no mesmo ano a taxa de homicídios brasileira foi de 17,0 para cada 100.000, enquanto a de Cali, considerada a cidade mais violenta do mundo, era de $73,0^{128}$.

Muita coisa mudou desde então: a taxa de homicídio do Jardim Ângela para 2006, considerando a população geral é 31,9 para cada 100 mil habitantes. Para a população masculina, nesse mesmo ano, é de 58,9. Recortando a faixa etária entre 15 e 24 anos, sobre para $125,7$.

O gráfico 4 permite comparar a taxa de mortalidade por agressões ocorridas no Jardim Ângela com distritos muito semelhantes do ponto de vista sócio-econômico e mostra como, mesmo dentro desse grupo, a região ainda destaca-se como uma das mais violentas.

\section{Gráfico 1 Homicídios por Distritos de São Paulo} Fonte: Fundação SEADE

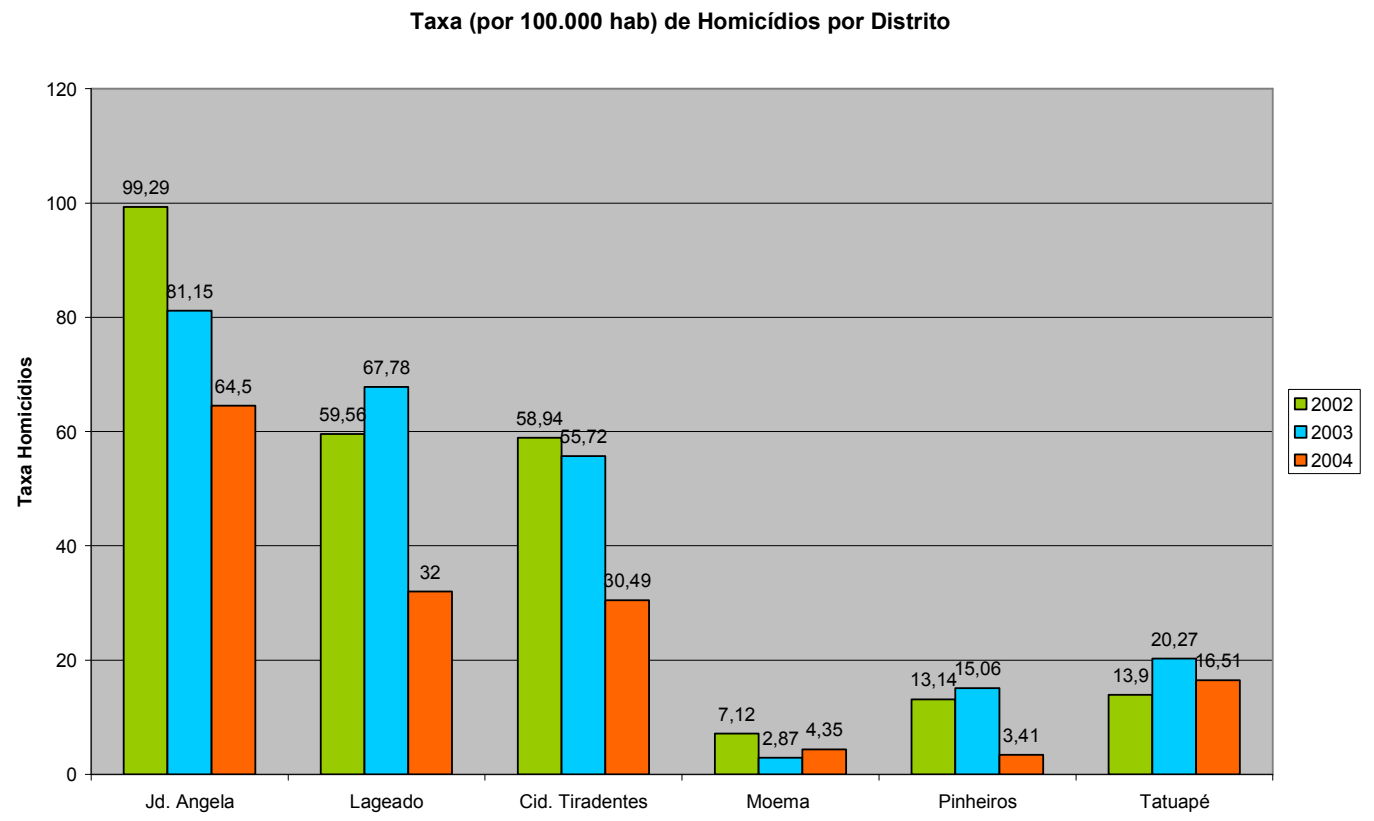

\footnotetext{
${ }^{127}$ Programa de Aperfeiçoamento das Informações de Mortalidade da Prefeitura Municipal de São Paulo (PRO-AIM).

${ }^{128}$ Kahn, Zanetic, 2002.
} 
O Jardim Ângela faz parte do padrão de urbanização que data dos anos 1940, chamado de “centro-periferia”. Segundo Caldeira ${ }^{129}$, ele é caracterizado 1. pela dispersão e conseqüente redução da densidade demográfica; 2. distância física das classes sociais no espaço; 3.aquisição da casa própria como regra seja para ricos ou pobres e, por fim, completa o padrão, 4. a circulação da população dividida entre ônibus para os pobres e carro para as classe mais ricas.

As pesquisas do Centro de Estudos da Metrópole ${ }^{130}$ atualizaram esse padrão, apontando que a situação da segregação de pequena escala em São Paulo faz com que grupos populacionais de menor renda e escolaridade não sejam encontrados nas regiões da cidade habitadas pelos grupos mais bem posicionados (sendo a favela de Paraisópolis uma exceção). Assim como Caldeira, os estudos apontam um movimento de expansão dos condomínios fechados em áreas antes periféricas, sem que isso tenha alterado o padrão da cidade. Nas palavras de Marques “' [...] a estrutura urbana em São Paulo é grosseiramente radial e concêntrica, relativamente heterogênea nas periferias, mas quase inteiramente exclusiva nas áreas ricas - o chamado setor sudoeste"131.

Do ponto de vista urbanístico, além de enfrentar a segregação imposta aos bairros da periferia em São Paulo como um todo, o Jardim Ângela é também uma região cujo território é, quase na sua totalidade, uma "área de proteção aos mananciais", ou seja, localiza-se numa região sujeita a regulamentação relativa ao uso e ocupação do solo, que se refere à taxas de ocupação, restrições às atividades desenvolvidas no local com potencial poluidor, além do manejo da vegetação. Tal regulamentação não foi capaz de impedir a ocupação territorial da área, mas acabou potencializando seu caráter irregular. Com efeito, o distrito pode ser qualificado por uma urbanização desequilibrada socialmente, caracterizada pela segregação territorial. Nos termos urbanísticos, é descrito como uma "ocupação espacial intensa", marcada pela "informalidade ${ }^{132 "}$.

Ocupação pouco ordenada ${ }^{133}$ parece ser uma boa ilustração para caracterizar as casas de alvenaria e os barracos que se misturam, intercalados algumas vezes por terrenos vazios. As

1292000 .

130 Idem.

${ }^{131}$ O Estado de São Paulo, 21.05.2006.

${ }^{132}$ LABHAB, 2003.

133 Em diversos textos urbanísticos sobre a região, encontrei a expressão "ocupação desordenada". Prefiro, contudo, caracterizar a ocupação como "pouco ordenada", uma vez que de fato há uma ocupação irregular do território. Mas mesmo essa irregularidade hoje é orientada por uma série de padrões compartilhados e toda as pessoas com quem conversei sabiam indicar com precisão quais era as áreas legais e ilegais do espaço, sem que isso se constituísse, contudo, como um impeditivo à construção . Há uma extensa bibliografia desde a década de 1980 que discute padrões de ocupação em terrenos ilegais (Maricato, 1996, 2001; Rolnik, 1997, 1998). 
casas podem estar distribuídas por terrenos não necessariamente legais, mas claramente identificados como tal. Sabe-se, por exemplo, que ao construir ou sublocar uma casa num terreno que "é da prefeitura", o futuro proprietário não vai pagar pela água.

Além da caracterização de uma paisagem vulnerável, uma marca das periferias de São Paulo, as considerações no campo do urbanismo interessam a essa reflexão também numa perspectivas mais pragmática. A disputa pelo espaço e os padrões de vizinhança que resultam desse tipo de ocupação, fazem parte da origem de uma parte relevante dos conflitos nessas áreas. Não por acaso o tema da "regulação fundiária" é hoje uma política que está também no campo da prevenção da violência ${ }^{134}$.

A remoção da população de favelas ou de casas construídas em áreas de proteção é comumente tema de conflitos entre moradores, movimentos sociais e o Poder Público. Mas, além dos conflitos dessa natureza, a transferência, por exemplo, de moradores de "barracos" para conjuntos habitacionais do tipo "Singapura", tem outros efeitos e significados além daqueles envolvidos numa política de habitação. Morar num apartamento e não mais numa casa, impõe novos padrões de vizinhança e convivência que, em alguns casos, acabam se constituindo como uma fonte de conflitos.

Nos últimos dois anos o Jardim Ângela vem recebendo novamente a atenção da imprensa, desta vez como exemplo de sucesso na redução da violência. As análises de especialistas em diversas áreas apontam a combinação de políticas e investimentos sociais, a ação do Estado e das ONGs somadas à mobilização comunitária como a essência da estratégia de sucesso. 0 gráfico 1 mostra a evolução do número de homicídios no distrito nos últimos anos e podemos observar que de fato houve uma redução significativa de mortes. Contudo, o gráfico 2 permite a comparação com outros distritos da periferia de São Paulo e revela que ainda estamos falando de um número elevado de homicídios e que o distrito segue sendo um dos mais violentos de São Paulo, ficando atrás apenas do Grajaú.

\section{Gráfico 1}

${ }^{134}$ O "Caso de Bogotá", por exemplo, hoje um clássico das políticas de prevenção, tem na sua lista de intervenções as políticas de regulação fundiária. 


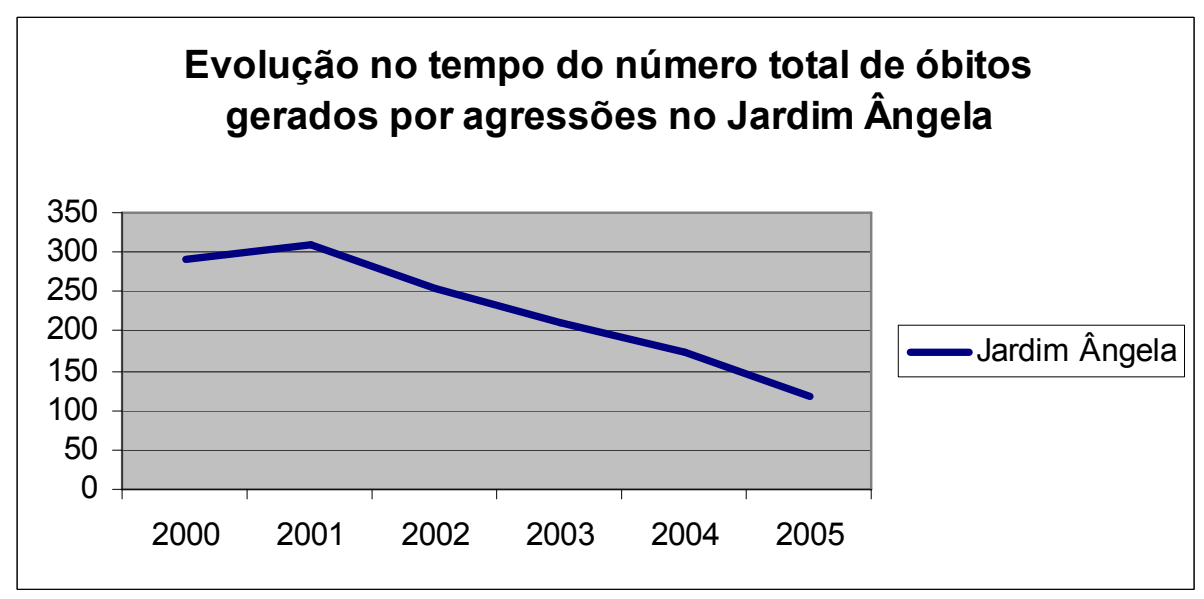

\section{Gráfico 2}

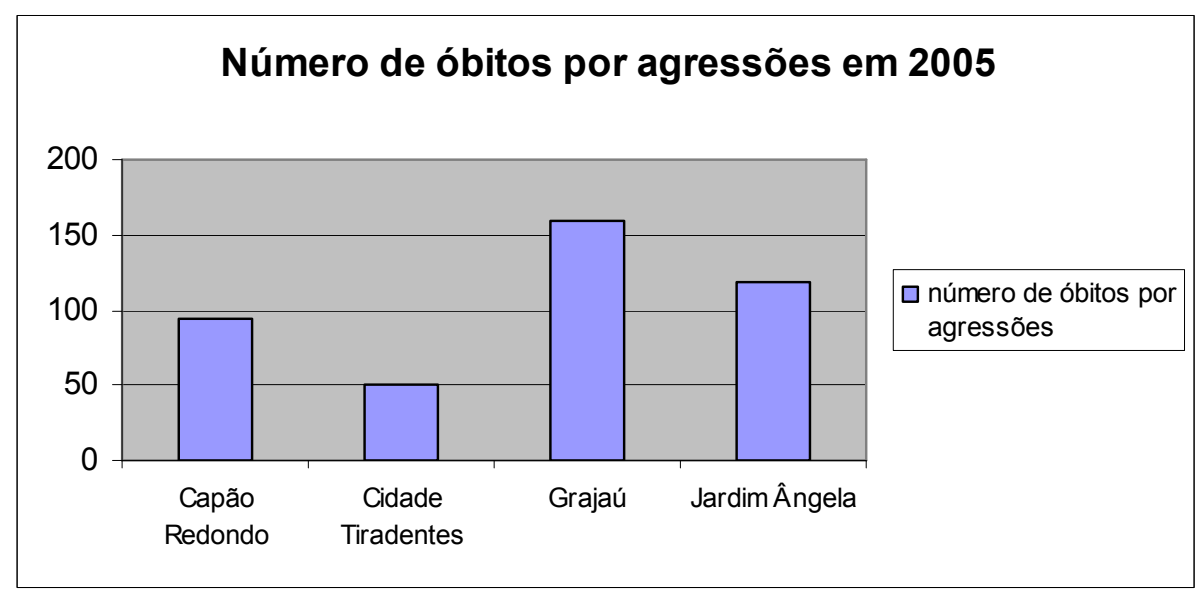

Além da pergunta óbvia sobre as causas que levaram o bairro ao posto de região mais violenta da cidade, o elevado número de mortes coloca uma série de outros questionamentos: De que maneira os homicídios foram incorporados à vida da região? Qual seu impacto na sociabilidade local?

Hoje o Jardim Ângela é conhecido como o distrito que "venceu a violência". Nesse processo, o bairro viu uma parte importante da sua história ser construída - do ponto de vista simbólico e concreto - ligada ao tema da violência e da criminalidade. Há uma correlação clara entre a atenção da mídia, o investimento do Estado e das ONGs na região e os níveis de violência praticados. Como elemento de estigmatização de um bairro e de seus moradores, na 
qualidade de obstáculo a ser transposto ou na forma de conquista, a violência tornou-se um passaporte para a visibilidade dessa periferia tão distante do centro.

O "Fórum em Defesa da Vida" é um espaço de articulação de organizações da sociedade civil locais ou que realizam trabalhos na região. Criado em 1996 e liderado originalmente pelo Padre Jaime Crowe, da paróquia Santos Mártires; um irlandês que chegou ao Brasil em 1969 e desde 1986 mora no Jardim Ângela. O Fórum tinha como objetivo original promover a “Caminhada em Defesa da Vida", realizada pela primeira vez também em 1996, no dia de finados. A caminhada pretendia lembrar as vítimas da violência na região, mas era também, uma estratégia para chamar a atenção da mídia e da sociedade em geral para o altíssimo número de mortes no Jardim Ângela.

Atualmente esse espaço de articulação comunitária reúne mais de 200 entidades, entre organizações não governamentais que trabalham com temáticas diversas, tais como urbanismo, prevenção à violência, juventude, além de associações de moradores, representantes da Polícia Militar, políticos locais, entre outros participantes. As reuniões acontecem uma vez por mês e são um espaço onde são debatidos os problemas do bairro, as propostas das organizações e as estratégias de mobilização dos grupos.

A criação do Fórum, bem como sua história se misturam de maneira quase que indistinta com o processo de visibilização da violência no distrito do Jardim Ângela. A concepção do Fórum é lida como uma resposta da comunidade à violência sofrida pelos moradores, mas também ao título de bairro mais violento do mundo. Ao mesmo tempo, no entanto, sua consolidação e o avanço das suas atividades aumentavam na medida em que o distrito do Jardim Ângela ganhava a atenção das organizações governamentais, do Poder Público e da mídia, por conta das altas taxas de homicídios na região.

Nesse sentido, ao longo de todos esses anos, o Fórum transformou-se em muito mais do que um espaço de mobilização e articulação comunitária. Essa é sem dúvida uma dimensão extremamente importante da suas atividades: é um ambiente inédito onde lideranças comunitárias podem, por exemplo, denunciar abusos praticados por policiais que atuam na região para a própria Polícia Militar. Mas, mais do que isso, o Fórum é uma arena política importante onde são legitimadas ou não seus participantes, os projetos a serem desenvolvidos na região, onde parceiros são reconhecidos como tal, e onde há uma constante disputa de espaço político e simbólico.

O Fórum pode ser visto como uma espécie de filtro entre "os de dentro" e "os de fora", mantendo um equilíbrio tenso entre os "desejos da comunidade", dos quais ele (ou as 
organizações que o compõem) seria um representante legítimo, e as atividades da ONGs “de fora".

A queda dos homicídios no Jardim Ângela é responsável pela redução das taxas de São Paulo como um todo e no caso do distrito o dilema relativo ao diagnóstico se reproduz: especialistas das mais diversas áreas apontam combinação entre a atuação do Poder Público, projetos desenvolvidos por ONGs e a mobilização comunitária local como responsável. Ao longo dos últimos anos, escutei explicações que agregavam mais atores (como o Ministério Público, ou a atuação da Polícia especificamente). Na disputa travada pelos diversos atores políticos envolvidos nesse processo, nesse caso, o Fórum também reclama a responsabilidade direta pela queda da violência na região.

O exemplo do Fórum em Defesa da Vida, mais do que a descrição de uma manifestação comunitária no distrito, tem o objetivo de mostrar que, além da sua dimensão mais evidente o elevado número de mortes -, a violência foi capaz de acionar outros tipos de dinâmica na região como a constituição de um ator político local importante.

Mesmo após ter "vencido a violência", o Jardim Ângela ainda é extremamente fragilizado por ela, e aqui, novamente no plano concreto (como vimos, as taxas ainda são muito altas) e no plano simbólico. Logo, atentar para o modo como diferentes atores sociais travam um diálogo com a violência é um dos caminhos para compreender como ela foi incorporada à vida da região.

\section{III, Um grande Campo de Futebol}

Seguindo a M'boi, passando a Base Comunitária e virando a direita depois da padaria ${ }^{135}$ chegamos no Parque Novo Santo Amaro (PNSA). O aglomerado de "barracos" não deixa espaço para dúvidas quanto à paisagem; estamos num lugar que chamamos de favela.

O Parque Novo Santo Amaro é mais um dos bairros da Zona Sul de São Paulo. Próximo à divisa com o município de Itapecerica da Serra, está localizado entre o Jardim Nakamura e o Parque Santo Antônio. O bairro faz parte do distrito do Jardim Ângela e tem hoje, de acordo com os dados da Prefeitura, aproximadamente 21.00 habitantes.

Seguindo os padrões da região a área é resultado da “[...] expansão sul-sudoeste da metrópole paulista, conservando características rurais em um primeiro momento, para depois ganhar a condição de aglomerado urbano periférico e desestruturado ${ }^{136 "}$.

${ }^{135}$ Foram essas as instruções que recebi na minha primeira visita ao local que descrevo a seguir. 
A área do bairro é também manancial da Represa Guarapiranga, com características do terreno que provocam deslizamentos constantes ocasionados pelas chuvas, além do lixo e esgoto permanentemente acumulado nas encostas.

É conhecido pelos moradores do local e dos bairros vizinhos como um dos "pedaços" mais violentos da Zona Sul. Não são os dados que mostram isso, uma vez que os homicídios são registrados de acordo com o distrito administrativos, nesse caso o Jd Ângela, ou de acordo com os distritos policiais. Mas a fama de bairro violento é uma espécie de senso comum, reiterado pelas mortes contabilizadas pelos próprios moradores. É sabido na região que é o PNSA é um dos locais onde mais se mata e morre em toda Zona Sul.

A paisagem é simples, porém densa. Lembra um vale baixo, composto por favelas que rodeiam um centro, o grande campo de futebol; uma referência espacial e social do bairro. $\mathrm{Na}$ beira do campo fica a sede da Associação de moradores e do outro lado da rua, a escola estadual que atende a região. 0 vestiário na outra ponta do campo e um pequeno trecho de arquibancadas improvisadas ajudam a desenhar o contorno do campo.

Exatamente em frente, do outro lado da rua, há uma praça minúscula, com uma única árvore e uma pequena mesa de xadrez e alguns bancos. Do outro lado da praça, um bar, com uma mesa velha de sinuca. Do lado desse, mais um bar, cinco metros mais adiante, logo ao lado da associação de moradores, mais um bar.

Nos finais de semana o pequeno trecho da rua compreendido entre o campo e a escola é fechado por iniciativa dos próprios moradores. E assim, de maneira também improvisada, eventuais atividades de lazer acontecem na escola nos finais de semana.

"Essa noite mataram um garoto na porta da minha casa", me disse "seu" Paulo, nos nossos primeiros cinco minutos de conversa, na minha primeira visita ao PNSA. O senhor sabe por que? "Não, não sei, mas é sempre a mesma coisa. Ouvi os tiros, mas não podia sair pra ver o que era, mas no dia seguinte saí na rua e tava lá o corpo do menino". O Sr. conhecia? “Conhecia assim, de morar aqui, mas não conhecia não”.

O que Seu João queria dizer é que conhecia o menino, já que no bairro todo mundo se conhece, mas não sabia o motivo da sua morte, nem o tipo de atividade na qual ele estava envolvido.

Nesse dia, depois de andar uma pouco pelo bairro, fomos tomar uma cerveja num dos bares em volta da praça. No bar estávamos eu, Marcelo, e mais um amigo, seu irmão, outros

${ }^{136}$ Ross, Villela: 2003. 
homens, moradores locais e mais ninguém. Não havia outra mulher (elas estavam na rua, do lado de fora), não havia mais nenhum jovem. Pensei nos números. 0 que estava faltando para que uma situação exatamente como aquela que vivíamos virasse um briga e terminasse numa morte?

A partir desse dia, minhas visitas passaram a ser constantes ao PNSA e, além da pesquisa propriamente dita, comecei a desenvolver outras atividades no local: uma biblioteca comunitária, reuniões com a associação de moradores, um curta sobre o time de futebol local para registrar a memória do time.

O fato de ter um irmão médico, e na época fazer sua residência num hospital público da Zona Sul, me converteu rapidamente num canal imediato entre o hospital e a comunidade. Meu irmão viu, atendeu ou encaminhou diversos casos de amigos, parentes e conhecidos de Marcelo com doenças que variavam na gravidade.

Essas atividades eram, ao mesmo tempo, um causa e consequiência da minha aproximação com aquela comunidade e com a família de Marcelo em particular.

Boa parte da população do bairro chegou em São Paulo na década de 70, muitos migrantes vindo de Minas, quando, nas palavras de quase 100\% dos meus entrevistados, “isso aqui era só mato". Essa descrição da paisagem antiga era recorrente mesmo entre aqueles que não tinham idade para terem vivido na época do mato, como o próprio Marcelo. Toda vez que escutava isso, olhava em volta e me dava conta de que para os meus padrões, havia ainda uma grade quantidade de mato.

A vida naquela época me foi descrita sempre como mais fácil, mais simples, mais bonita. E,

aos poucos, as entrevistas foram me mostrando que muitas daquelas pessoas não chegaram em São Paulo na condição de pobreza na qual se encontravam nos dias atuais.

A trajetória de Marcelo, na condição de jovem, homem, morador da Zona Sul, retrata em parte a história que é descrita pela periferização e empobrecimento do bairro, assim como mostra o entrelaçamento da violência no seu cotidiano. A história de sua família descreve essa vida que vai deixando de ser fácil, simples e bonita, para ser a vida do jeito que ela é nos dias de hoje.

Uma parte grande da família de Marcelo mora ou no bairro ou nas redondezas. 0 primeiro a chegar foi seu avô, nos anos 70, quando, de acordo com Joana, mãe de Marcelo, “aqui era só mato". Seu avó comprou o terreno onde hoje é casa da sua mãe. Seu pai conseguiu logo cedo 
um emprego na construção civil onde trabalhou por muitos anos, até ser mandado embora e nunca mais conseguir um novo emprego.

A perda do emprego do pai é um divisor de águas para a família. Até então, Joana ficava em casa tomando conta dos filhos. Depois disso, foi ela que, trabalhando como empregada doméstica, passou a sustentar a casa. Marcelo tem duas irmãs e um irmão. "Eu não tinha tempo de cuidar dos meus filhos porque ficava cuidando dos filhos da minha patroa". Joana me conta, dizendo também que o marido, já desempregado, passava o dia todo no bar.

Quando Marcelo tinha 16 anos, seu pai morreu num hospital público, depois de ficar 8 horas sem atendimento, enquanto esperava no pronto socorro.

Marcelo é hoje uma liderança comunitária no bairro onde mora e sua biografia contribui em parte para isso: a despeito da perda precoce do pai e das dificuldades vividas pela família, ainda muito jovem acumulou uma série de conquistas, entre elas um emprego e o ingresso na faculdade. Nenhuma delas está relacionada a atividades ilícitas e, por isso, ele é percebido na sua comunidade como alguém que "deu certo”; um "exemplo a ser seguido".

Com veremos, no entanto, não é possível separar por completo sua vida da violência que impera na vida de seu bairro. Nas conversas com Marcelo ela se apresenta na forma mais óbvia: o medo. Acompanhando seu dia-a-dia, seus problemas, aspirações e dilemas, percebemos, no entanto, que a violência também se faz presente de uma maneira mais sutil, mas igualmente relevante: ela é uma espécie de filtro através do qual a vida como um todo é submetida e decifrada.

\section{Jogo de futebol e a ameaça de morte}

Em 2006 eu estava ajudando a organizar um pequeno torneio de futebol no campo do bairro. O objetivo do jogo, além da diversão em si, era promover a construção da biblioteca comunitária na associação de moradores local. Haveria um time "da comunidade" (obviamente favorito na competição), um time de amigos meus e um time da organização não-governamental na qual eu trabalhava na época.

A partida, no entanto, nunca aconteceu. Na noite anterior recebi um telefona dizendo que o jogo de futebol, marcado para a manhã seguinte, teria que ser cancelado. Era uma sextafeira e na tarde desse mesmo dia um menino tinha sido morto no campo. 0 matador, além de cometer o crime, havia deixado um aviso: Marcelo seria o próximo. Sem saber o motivo da ameaça, Marcelo teve que sair do bairro naquela mesma noite, deixando para trás a mulher, 
filho, assim como o resto da sua família. Ficou hospedado durante uma semana na casa de um outro amigo, longe do bairro onde morava, até conseguir alugar uma casa nova, para onde se mudou com a mulher e o filho. A ameaça persistiu na forma de um juramento de morte. Marcelo não tinha perspectivas de voltar a morar tão cedo no seu antigo bairro.

Esse episódio permitiu que eu me aproximasse de outras dimensões da violência até então pouco claras. Mais do que o ato de matar em si, uma ameaça e suas conseqüências mostraram-se como guias interpretativos férteis, mobilizando diversas esferas das redes de sociabilidade local.

Passada a urgência posterior à ameaça de morte feita a Marcelo e a mudança de sua família do bairro, este decidiu investigar porque havia sido jurado de morte. Segundo ele, o “matador" não poderia simplesmente matá-lo, tinha que ter um motivo, uma boa explicação, e, mais do que isso, tinha que circulá-la na comunidade. Nas palavras de Marcelo "Não pode matar por matar".

Conversando com outros moradores, Marcelo descobriu que a ameaça foi justificada pelo fato de que, supostamente, corria um boato de que Marcelo estaria levando uma Base Comunitária da Polícia Militar para o bairro, o que obviamente atrapalharia a vida do matador, foragido da polícia. Sendo assim, esse teria uma razão para matá-lo.

Essa história, contudo, não era verdadeira, Marcelo não estava levando uma Base da PM para o bairro e nem tinha como fazê-lo. A alocação das bases comunitárias está a critério do Comando da Própria Polícia Militar. Marcelo não havia feito nenhum movimento nessa direção. Como, então, explicar a história?

Marcelo e seu algoz cresceram juntos, freqüentaram a mesma escola, e, segundo Marcelo, brincavam lado a lado, jogavam futebol no mesmo campo (onde o jovem foi assassinado na véspera da partida).

"Ele almoçava na minha casa, às vezes dormia na minha casa, conhece minha mãe, meus irmãos".

A semelhança na trajetória dos dois, no entanto, se encerra por aí. Marcelo, ao terminar a escola, participou de um curso promovido pela Polícia Militar no bairro e desde então se enveredou no universo dos projetos sociais, arrumou um emprego e entrou na faculdade. Ricardo, segundo Marcelo, "até tinha um emprego, mas no final de semana botava uma arma na cintura e ia matar quem ele achava que tinha que matar. Aos poucos, foi ficando mais entocado (na favela) 
porque tinha que fugir da polícia, largou o emprego, se juntou com os meninos do tráfico $e$ agora fica aí, só matando as pessoas, é só isso que ele faz".

Podemos pensar que é a presença de Marcelo e não da Base Comunitária o que coloca em risco a existência de Ricardo. Ambos têm trajetórias semelhantes com desfechos distintos. Marcelo é uma liderança comunitária, compartilha suas conquistas com a comunidade: leva pessoas de fora para o bairro, promove atividades e é constantemente procurado por jovens que querem sair do crime. Ao contrário de Ricardo, que vive entocado, Marcelo circula, não só na favela, mas fora dela. Nesse sentido, a existência de Marcelo como alguém que passou pelas mesmas dificuldades impostas pela vida na periferia, mas que ainda assim "deu certo", deslegitima, em certa medida, as escolhas de Ricardo.

$\mathrm{Na}$ terceira conversa com Marcelo sobre o caso, soube que a história tinha origens mais antigas e não se resumia ao episódio da ameaça.

"Eu vi o tio do Ricardo atirar no meu tio. Eu vi e nunca pude fazer nada".

Marcelo me contou que quando era pequeno, tinha um tio que, porque "era fraco das idéias" acabou envolvido com o crime. Numa determinada ocasião, há muitos anos atrás, o tio de Ricardo, atirou no tio de Marcelo na sua frente. Esse não morreu (morreu depois, de tiro também), mas a família nunca pôde fazer nada a respeito do episódio.

"Passei muito tempo engolindo essa história, sem poder dizer nada. Ele ia no mercadinho do meu tio, passava na frente da casa da minha mãe e cumprimentava a gente, e ninguém podia falar nada ou fazer nada. Agora pra mim chega, não agüento mais. Você sabe o que é ver a mesmo coisa se repetir sempre, sempre, sempre? Quantas pessoas já morreram na mão desses caras? Quantas pessoas vão morrer ainda?"

Sua maneira de contar a história traz muitos elementos relevantes. Do ponto de vista pessoal, essa parece ser uma briga antiga com a sua família, que, como não compartilha a lógica de matar não pretendia tomar uma atitude em relação à violência sofrida pelo tio. Sabiam do fato, mas não podiam tirar satisfações, vingar o tio, ou mesmo denunciar tudo para a polícia. De acordo com Marcelo, era preciso viver como se nada tivesse acontecido. 
Não seria a ameaça a Marcelo uma atualização dessa história? Sabendo que a família de Marcelo não faria nada, como não havia feito no primeiro episódio, Ricardo jurou Marcelo de morte como uma forma de afastá-lo do bairro.

Nessa nova versão da história, no entanto, as coisas parecem não estar caminhando como previsto. Marcelo iniciou nossa última conversa, dizendo que "as coisas estavam andando". Ele havia conversando com um promotor, e estava denunciando Ricardo, assim como outros criminosos da região, para a polícia. Achei extremamente arriscado; ele não estaria se expondo? Segundo ele, não:

"a polícia está trabalhando direito e, inclusive, numa das batidas, acabou matando dois deles".

Matando? Ao ouvir isso, fiquei surpresa e chocada. Minha primeira reação foi the dizer que os policiais não podem fazer isso.

"Você vai ficar chocada com o que eu vou te falar, mas a única solução é matar todos eles. A polícia tem que vir e matar todos eles. Não tem outro jeito, vai fazer o que? Vai prender? 0 tio deles foi preso, cumpriu um terço da pena, ficou oito anos preso e depois? Saiu e em uma semana matou seis pessoas."

Pergunto se isso resolveria de fato o problema. Afinal, sabemos, eu e ele, que a origem do problema não está nesses meninos. Você não acha que se eles morrerem outros vão aparecer? Tento provocar algum tipo de reflexão que o demova da idéia de que a morte é uma solução.

“Mas Paula, você acha que adianta prender e soltar, você acha que adianta deixar ele dentro da prisão comandando quem vai morrer?".

Não tenho resposta. Sei que ele está correto no seu diagnóstico. Prendê-los apenas não resolveria, pelo menos não esse caso específico.

"Eles têm que acabar e, ao mesmo tempo, tem que ter investimento social na região para que outros moleques não queiram seguir o mesmo caminho"

Ouço sua vontade de justiça (ou será de vingança?) até o fim. A conversa tem uma conclusão silenciosa. Acho que esse é o primeiro momento em que, de verdade, compartilhamos o 
mesmo sentimento. Tenho a impressão de que estamos ambos pensando que o mundo não tem mesmo jeito.

A solução colocada em curso por Marcelo é, sem dúvida, mais uma estratégia privada de resolução de um problema que, em tese, deveria acionar instituições públicas. A seqüência de acontecimentos - o tiro no tio, a ameaça de morte, o exílio do bairro, a denúncia para policia e a morte dos supostos criminosos - torna ainda mais nebulosos os limites entre bom e mau, certo e errado, crime e lei.

Em que medida Marcelo se diferencia dos matadores? Em muitas, claro. 0 fato de que ele seria incapaz de matar alguém, talvez seja o traço mais distintivo. No entanto, numa determinada situação, tolera que a polícia mate. Nesse sentido, Marcelo, parece partilhar o desprezo pela justiça formal e, assim como eles, parece confiar mais na idéia de fazer “justiça com as próprias mãos”, ainda que essas mãos não sejam suas.

E em que medida Marcelo se diferencia do seu próprio algoz? Sob uma determinada perspectiva estamos falando de duas situações completamente diferentes. No caso de Ricardo, trata-se de um matador, com uma série de crimes nas costas, disposto a cometer mais um. No caso de Marcelo, ele não cometeu crime algum. Ao contrário, seguiu os procedimentos necessários: procurou um promotor, denunciou os criminosos à polícia e colaborando com toda a informação que podia, colocou a própria vida em risco.

Mas o fato de que Marcelo vê nas mortes praticadas pela polícia nesse caso como uma solução (mesmo que descrita como extrema e resultante de um quadro sem muitas alternativas) mostra como duas narrativas, aparentemente tão antagônicas, também podem ser interpretadas numa mesma chave. Os paralelos entre as histórias indicam um tipo de sociabilidade compartilhada, segundo a qual a morte não só é tolerada, mas é um desfecho possível e legítimo.

\section{História do tio}

Como grande parte da família de Marcelo mora no bairro, a casa de Joana, sua mãe, é sempre cheia. Além da família que reside lá (junto com a mãe, na época moravam Marcelo, sua mulher e filho, o irmão, a mulher e o 10 filho, a irmã e um filho, uma outra irmã e mais um amigo da família), a casa é sempre cheia de visitas ou hóspedes temporários.

Conheci muitos desses parentes em festas na casa de Joana ou em outros evento no bairro. Um dos tios, irmão do seu pai, é o chefe de uma família com três filhos, moradores do bairro 
vizinho, também na Zona Sul. Nunca havíamos nos encontrado, ou, pelo menos eu não me lembrava de tê-lo visto. Foi por telefone que fiquei sabendo da existência do tio e do problema com o qual ele havia se envolvido.

De acordo com o que me contou Marcelo, sua irmã foi visitar seu tio levando o sobrinho, filho de Marcelo e mais uma criança. Já no bairro do tio, o grupo foi abordado por dois jovens que de longe gritaram “vocês são do Parque Santo Amaro, não são?” enquanto corriam na direção dos três, ao que tudo indicava, para agredi-los. Correram "pelo meio do mato para fugir dos meninos", em direção à casa do tio de onde só puderam sair tarde da noite.

No dia seguinte ao episódio da perseguição, o tio recebeu uma ameaça de morte pelo mesmo grupo. Diante da intimidação, foi imediatamente procurar Marcelo.

Soube da história quando o tio já estava "foragido" com toda sua família no bairro de Marcelo. A conseqüência imediata é que ele teve que alugar uma casa nova e como não tinha dinheiro para isso, precisou pedir emprestado.

Ouvindo o relato do acontecido eu não conseguia encontrar sentido na agressão, tampouco (ou muito menos) na ameaça. Não havia um conflito, não havia em todo o enredo um elemento que indicasse uma desavença ou qualquer outro estopim que justificasse uma ameaça de morte.

Manifestei minha incapacidade de compreender a história, sobretudo os motivos que haviam provocado o ataque original. Marcelo não soube me explicar nada além daquilo que estava narrando. De todo modo, essa parecia ser uma preocupação apenas da minha parte.

Marcelo fez um boletim de ocorrência de ameaça e agressão. Seu gesto foi interpretado como uma atitude de imensa coragem. Com a denúncia feita, a polícia foi ao local e prendeu um dos jovens acusados e o manteve preso por um dia e meio. Tal iniciativa por parte do delegado me foi descrita por Marcelo quase que como "um favor", já que dentro da lei não havia outra coisa que pudesse ser feita. Segundo ele, ao fazer isso, o delegado pretendia dar um susto nos jovens.

A explicação da polícia que me foi reproduzida por Marcelo convergia com aquela que ele havia contado: os jovens agressores estavam querendo se impor como organização criminosa local e ameaçar e atacar as pessoas era sua estratégia. A ameaça nesse caso cumpria duas funções: credenciar os jovens como crime organizado com poder na região e, ao mesmo tempo, se apropriar dos eventuais bens que a família, diante da ameaça, deixaria para trás. 
Como havia me envolvido pessoalmente com a história, nas semanas que seguiram, sempre perguntava a Marcelo "Como vai seu tio?" A resposta era sempre a mesma: “vai bem”.

Nunca mais tive noticias sobre a denúncia, sobre uma eventual investigação que pudesse ter sido conduzida pela polícia, ou mesmo sobre os agressores. Uma vez o tio de Marcelo acomodado na nova casa, as crianças matriculadas na escola do novo bairro, a família (incluindo Marcelo) parece ter abandonado o episódio e retomado a vida cotidiana.

A história envolvendo o tio de Marcelo chama a atenção em vários sentidos que não apenas aqueles imediatamente realçados pela dose de violência envolvida no episódio. Em primeiro lugar, surpreende o caráter aleatório dos acontecimentos. Se sua irmã não tivesse ido visitar o tio os alvos seriam outros? Ou, de maneira inversa: se esse não fosse o pretexto para ameaçar o tio, os jovens criminosos em ascensão teriam arrumado outro? Tal aleatoriedade é especialmente desproporcional quando considerada a gravidade das ameaças feitas e extensão das conseqüências práticas. 0 tio teve que pedir dinheiro emprestado, a família inteira foi obrigada a deixar para trás um bairro onde morava há anos, Marcelo se arriscou ao fazer o boletim de ocorrência, as crianças mudaram de escola no meio do ano letivo. Tudo isso e mais outras conseqüências que de fora não sou capaz de avaliar, de maneira absolutamente inesperada e abrupta.

Finalmente, se estar sujeito a uma ameaça de morte de maneira tão repentina é capaz de chocar, é igualmente impressionante como todo o episódio foi absorvido e processado pelas vítimas, transformando-se numa história que ficou para trás.

Ambas as histórias, envolvendo Marcelo e seu tio, aconteceram com cerca de um ano de diferença. A princípio não estabeleci nenhum tipo de ligação entre as duas. Afinal o contexto, os agentes e os alvos das ameaças eram diferentes. Foi a pergunta de meu irmão, ao ouvir a história do tio de Marcelo, que chamou minha atenção: “mas o que ele faz pra estar sempre metido numa confusão?" Nada, ele não faz nada, foi minha reação imediata.

O que eu quis dizer com minha resposta foi que Marcelo não ia procurar essas "confusões" ele não está envolvido com o crime, não tem dívidas, domina o idioma das ameaças e por isso toma os cuidados necessários. Na minha interpretação, elas é que o procuravam.

Aos poucos relembrei outras histórias contadas por ele, episódios que aconteceram antes de nos conhecermos e que envolviam ameaças a sua vida ou integridade física como, por exemplo, os "enquadros" da polícia, e particularmente a vez em que sua esposa, com medo do que poderia acontecer caso ele fosse levado na viatura (ele me disse que tinha certeza de que os policiais o matariam longe dali), insistia para que os policiais a levassem junto. 
As duas histórias eram, assim, graves, mas não excepcionais; os eventos eram novidade apenas para mim. Na vida de Marcelo ocupavam um lugar limiar entre o cotidiano e a exceção.

E o caráter corriqueiro não deve ser atribuído à descrição etnográfica. Ele é acentuado pela maneira como os acontecimentos foram enfrentados.

A ameaça da morte com todas as suas conseqüências me parecia tão chocante quanto a facilidade (talvez rapidez seja o termo mais apropriado) com que os episódios foram superados e a vida normal retomada. Meu assombro desproporcional às reações por parte de Marcelo e de sua família é, nesse sentido, um sinal evidente de que há estratégias variadas entre pessoas que convivem com tipos diferentes de violência. Essas estratégias, por sua vez, não estabelecem uma correspondência rigorosa com risco vivido efetivamente. 0 cultivo cuidadoso do medo se mostrou mais relevante na criação desses parâmetros, quem sabe equivocados.

Considerar esse como mais um episódio da vida e "tocar pra frente" pode parecer, a princípio, uma boa estratégia de sobrevivência. Mas naturalizar a violência dessa maneira, ou tomá-la apenas como mais um dado que compõem seu universo, é questionável no que se refere à sua eficácia, sobretudo no longo prazo, uma vez que a violência já deu provas da flexibilidade dos seus limites.

Processos de assimilação podem ser também transformadores. Mas nesse caso, não estão em jogo apenas as possibilidades de mudança envolvidas em tais processos, mas, principalmente, qual seria o sentido dessa eventual transformação.

Ao referir-se à brutal violência colonial praticada contra os índios colombianos, Michel Taussig atribui à morte, ou ao "espaço da morte" um papel valioso na intercessão entre relações. Para o autor, "O espaço da morte é importante na criação do significado e da consciência, sobretudo em sociedades onde a tortura é endêmica e onde a cultura do terror floresce ${ }^{137, "}$.

No caso da manutenção da hegemonia colonial, o terror além de um estado fisiológico, seria também um estado social capaz de funcionar como um mediador.

Contudo, o autor consegue ver no "espaço da morte" também um ambiente com potencial transformador. 0 medo cumpriria o papel de propulsor de um aumento da autoconsciência, provocando a perda do autoconformiso diante da autoridade ${ }^{138}$.

\footnotetext{
${ }^{137}$ Taussig , 1993: 26.

${ }^{138}$ Idem: 29.
} 
Refletindo sobre o terror imposto pelas ameaças no PNSA ou acerca da possibilidade de morrer como nos dois casos relatados, o potencial transformador desse "espaço da morte", tal qual apontado pelo antropólogo australiano, parece ofuscado. Em que medida, ao incorporar e assumir que a violência "faz parte da vida" as vítimas estão rompendo com a ditadura da violência? Qual é o processo de auto-consciência em curso?

O grau de sujeição imposto pela violência deixa pouco espaço para reflexões dessa natureza. E a repetição dos episódios, com enredos muito semelhantes, reforça seu caráter inabalável. Soma-se a isso o fato de que, como veremos a seguir, os mecanismos para enfrentá-la não estão disponíveis. Aos poucos vai se desenhando uma tarefa impossível.

\section{A fumaça do bom direito ${ }^{139} \mathrm{X}$ o perigo da liberdade}

Ao registrar o Boletim de Ocorrência da ameaça e agressão feitas ao seu tio, Marcelo teve uma atitude pouco usual diante de uma situação como essa. A denúncia ${ }^{140}$ como veremos, não é uma prática comum.

O impasse é aparentemente contraditório uma vez que, se como essa vem sendo descrita, a violência é tão próxima e familiar, se as histórias relatadas compõem o cotidiano local num ritmo regular, não seria evidente que a polícia ou a justiça fossem acessadas com freqüência? E ainda, não seria esperado que os protagonistas de tal violência tivessem sua identidade conhecida pela comunidade? Grande parte dos matadores de fato é. Assim como são os traficantes e autores de outros tipos de crime envolvendo conflitos do cotidiano.

A idéia de um crime não esclarecido não é comum no interior da comunidade. Em grande parte das vezes o enredo é conhecido, os motivos são conhecidos, assim como o autor e as vítimas. Numa história de conflito violento, pelo menos um desses elementos é público. Durante todo o período em que realizei a pesquisa, entre todos os crimes ou ameaças das quais tive notícia, apenas um foi mais "nebuloso" e a princípio sem explicação. Em 2006, na época da Copa do Mundo, quando revirava um lixo, próximo ao campo de futebol, um mendigo encontrou um par de pernas. A polícia foi avisada, mas, num primeiro momento, ninguém parecia saber a quem pertenciam aquelas pernas, tampouco em que contexto elas

\footnotetext{
139 "Fumus boni iuris" é a expressão em latim usada para indicar a presunção de legalidade por parte do juiz quando diante de uma acusação e a conseqüente possibilidade e garantia de um direito.

${ }^{140}$ Do ponto de vista técnico a denúncia é a petição que inaugura a ação penal pública, assinada pelo promotor de justiça. O relato do fato criminoso à autoridade policial é denominado "notitia criminis".
} 
foram parar no lixo. Apenas muitos meses depois descobriram que a pernas eram do marido de uma moradora do bairro, que estava desaparecido há algum tempo. As causas, contudo, tanto do sumiço quanto da mutilação, não são conhecidas até hoje.

No caso dos matadores profissionais, estes são conhecidos não apenas pela comunidade, mas, em muitos casos também pela polícia. No livro-reportagem "Homem X" ${ }^{141}$, Bruno Paes Manso desvenda a vida desses personagens, homens que matam como uma atividade profissional remunerada, resolvendo desavenças ou cobrando dívidas de terceiros que os contratam para esse tipo de serviço. Alguns dos matadores apresentados pelo autor têm em sua biografia algo entre 10 e 20 mortes. As entrevistas realizadas por Bruno explicam a relação desses crimes com a trajetória pessoal de cada criminoso, as lógicas que cercam profissão, os riscos envolvidos, bem como as justificativas - mesmo de ordem moral - que os matadores constroem para elencar as motivações por trás dos assassinatos. 0 autor, que é jornalista, publicou uma matéria posteriormente ${ }^{142}$ na qual mapeava os locais de atividade dos matadores distribuídos nos bairros de São Paulo, o número estimado de mortes atribuídas a cada um deles, e, em alguns casos, a reportagem trazia até a foto dos assassinos. Em outras palavras, estamos falando de criminosos conhecidos cuja responsabilidade nas mortes apontadas é sabida e reconhecida, muitas vezes até mesmo pela polícia.

No próprio DHPP, os investigadores conhecem muitos dos homicidas - seu nome, biografia no crime e até seu rosto em alguns casos - mas não conseguem prendê-los por motivos diversos.

A trajetória de um dos matadores do PNSA, relatada de maneira breve por Marcelo, é exemplar nesse sentido. De acordo com ele, esse homem, atualmente um matador da região, que além dos assassinatos pratica outros tipos de crime tais como extorsão e ameaças generalizadas, não teve sempre essa vida.

“Ele trabalhava na Globo (Rede Globo) fazendo alguma coisa que eu não me lembro, mas tinha emprego e tudo. Uma época, não sei muito bem como começou, ele começou a sair pelo bairro, matando quem ele achava que devia. Aos poucos ele largou o emprego na Globo e agora só mata e rouba as pessoas".

Ouvindo o relato, e até mesmo por conta do modo sintético e didático como me foi contado, ficava claro que aquela não era uma história conhecida apenas por Marcelo e que tampouco estava sendo relatada por ele pela primeira vez. Essa era mais uma das histórias do bairro e o

\footnotetext{
${ }^{141}$ Paes Manso, 2005a.

${ }^{142}$ Paes Manso, O Estado de São Paulo, 2005b.
} 
tal matador, assim como sua trajetória, eram conhecidos pela população local. A pergunta que fiz a seguir era ao mesmo tempo óbvia, mas para mim, extremamente intrigante. Mas se vocês sabem de tudo isso, por que ninguém nunca denunciou esse cara para polícia?

“Porque a polícia não consegue prender ele. Porque ele fica entocado na favela, não sai, a polícia não sabe nem que cara ele tem. Isso acontece o tempo todo. E ninguém vai ter coragem de denunciar porque sabe que a polícia não vai prender e depois ele fica solto e vem cobrar a denúncia".

A dinâmica das ameaças, descrita em outros momentos desse trabalho, é um elemento fundamental para compreender a lógica que rege as relações entre pessoas ou entre grupos. Um determinante das estratégias de sobrevivência que dita limites daquilo que é permitido ou não, um indicador preciso das fronteiras do respeito e do medo, ela é também um elemento importante na definição da forma de se relacionar com a justiça. Ou, dizendo de outra forma, a prevalência da lógica das ameaças no desfecho das histórias é um indicador de relevo sobre como os espaços formais e legítimos para a resolução de conflitos não são conhecidos para serem acessados, ou não são reconhecidos como tal, ou são conhecidos, mas abandonados em situações como essas diante da sua pouca capacidade de solucionar os problemas.

A ausência de denúncias não é exclusiva à situação envolvendo matadores. A prática de não denunciar criminosos conhecidos, ou crimes sabidos, se reproduz em outros níveis e com outros tipos de crimes. Ameaças, agressões, tentativas de homicídios, além dos próprios assassinatos, tampouco são denunciados para a polícia.

Essa prática ou essa não-prática se dá, sobretudo, porque as vítimas ou testemunhas em potencial, claro, têm medo. Mas esse medo precisa ser compreendido de uma maneira ampla. Não se trata apenas de um medo imediato, que sozinho faria sentido. Ou do receio de uma retaliação. Ao pronunciar o perigo de uma represália, não denunciar está explicitando a certeza de uma incompatibilidade e um descompasso dos aparatos previstos pela lei e pela justiça com a realidade.

De fato, quando consideradas as instituições responsáveis, parece haver um abismo entre as histórias relatadas nesse trabalho e a legislação prevista para lidar com elas. A incapacidade de fazer justiça e, sobretudo, a incapacidade de proteger por meio da justiça, faz com que “Justiça” seja uma idéia remota e distante. 
De maneira sucinta, podemos dizer que o Código Penal brasileiro prevê três modalidades de punição para um crime: multa, restrição de direitos e a privação da liberdade. A natureza do crime, sua qualificação e os antecedentes do autor são elementos que vão determinar, o tamanho da pena a ser fixada pelo juiz, no caso da comprovação da culpa.

Tomando o caso específico da prisão, de acordo com o sistema brasileiro, ela tem duas naturezas distintas. A prisão pode constituir uma pena, no caso de um crime que já foi processado e julgado e seu autor foi considerado culpado, sem possibilidade de recursos. Nesse caso, a prisão tem caráter essencialmente punitivo ${ }^{143}$ e só pode ocorrer, portanto, quando há julgamento, condenação e a conseqüente necessidade de punição.

Mas a prisão pode ter também a natureza de uma medida processual cautelar (são as espécies de prisão provisória), que visa garantir o resultado útil do processo e ocorre durante o inquérito policial ou no curso do processo criminal. Ou seja, mesmo antes da fixação da autoria e culpabilidade de uma determinada conduta ter sido comprovada, um réu pode ter sua prisão decretada pelo juiz.

O Código de Processo Penal brasileiro, editado durante o Estado Novo, prevê cinco tipos de prisões provisórias: preventiva, flagrante, temporária, decorrente da pronúncia ou da sentença condenatória recorrível.

A prisão preventiva é garantida pela existência de requisitos previstos em Lei ${ }^{144}$, que autorizam a execução de uma medida cautelar excepcional. Nessa versão a prisão não remete à idéia de punição, sendo apenas uma medida cautelar preventiva.

A natureza ou a gravidade do crime, em abstrato, não devem interferir no decreto da prisão preventiva por parte do juiz. Além de ser necessária a existência de indícios de autoria para manutenção ou o decreto da prisão preventiva, a lei prevê ainda que, para a sua autorização é necessário concorrer um dos seguintes requisitos: garantia da ordem pública, da ordem econômica, conveniência da instrução criminal ou garantia da aplicação da lei penal. As duas primeiras dizem respeito à possibilidade do acusado praticar novos delitos e, nesse caso, a demora na condução do processo poderia representar um "perigo ou ameaça social".

O requisito da conveniência instrução criminal traduz a preocupação em garantir que eventuais testemunhas ou as provas envolvidas no processo não sejam prejudicadas ou intimidadas, caso o réu esteja em liberdade até o final do processo.

143 Ainda que não seja objeto desse trabalho, vale a pena sublinhar que há, entre correntes da criminologia, um debate acerca da natureza da pena - retributiva, ou ressocializadora.

${ }^{144}$ Art. 312 do Código de Processo Penal. 
Finalmente, a prisão preventiva que é decretada para garantir a aplicação da lei penal visa evitar a fuga do acusado e seu não cumprimento da pena, caso ele seja condenado, se, por exemplo, ele não tem um emprego ou residência fixa.

Importa notar que a prisão preventiva não debate a culpabilidade do acusado, conceito que inclui ou o dolo ou a culpa, como dizem os advogados, mas apenas os requisitos acima mencionados. Um acusado que fica preso preventivamente, pode chegar ao final do processo e ser considerado inocente e solto, ou pode ainda, caso seja considerado culpado, receber outro tipo de pena que não seja a privação de liberdade.

Essa lógica da prisão preventiva, que exige a comprovação de indícios de autoria e comprovação do risco decorrente da liberdade (ou da não decretação da prisão) do acusado deve ser aplicada a toda espécie de prisão provisória ou processual, em razão da influência que o sistema constitucional garantista exerce sobre a legislação que havia sido editada anteriormente, como o velho Código de Processo Penal, em vigor desde 1941. Por tal razão, hoje é consenso que a prisão provisória só pode ocorrer como medida cautelar. Mas mesmo que hoje diversos tribunais reconheçam esse fato, diversos juízes ainda consideram a natureza do crime em abstrato ao decretar uma prisão no curso do processo. Além disso, muitas vezes, a prisão provisória é decretada como uma forma de antecipação da pena, não importando que o réu ainda não tenha sido definitivamente julgado.

Um olhar mais atento sobre os tipos de prisão e os princípios que cada uma evoca são particularmente interessantes ao debate antropológico. Sobretudo porque trazem dimensões relevantes à discussão acerca dos direitos e da própria idéia de punição ${ }^{145}$. Para as reflexões desse trabalho, a prisão preventiva interessa particularmente na medida em que revela os impasses instituídos nessa combinação entre as formalidades da justiça quando confrontados com uma arquitetura social da vulnerabilidade.

A restrição à prisão preventiva deve ser lida como uma conquista democrática. É o princípio da "presunção da inocência" ou o princípio constitucional da não-culpabilidade, previsto no artigo 5 da Constituição Federal que garante "que ninguém será considerado culpado até o trânsito em julgado da sentença penal condenatória". Em outras palavras, a culpa do acusado só é reconhecida com a conclusão do processo de maneira definitiva irrevogável.

Responder a um processo em liberdade é, nesse sentido, uma conquista da Lei e uma aposta num modelo de sociedade onde a culpa, se não uma exceção, é menos comum do que a

145 Ao investigar a Justiça da Infância e Juventude, mostro na minha dissertação de mestrado (Miraglia, 2001), por exemplo, como, a despeito das disposições previstas na Lei, as idéias de "justiça" e "punição" são também construídas em arenas alternativas à legislação. 
inocência. Transparece no princípio a leitura da privação da liberdade como algo grave, uma violação do indivíduo. Cercar a possibilidade de prisão de requisitos pode ser interpretado como uma estratégia na garantia das liberdades e uma tentativa de aproximar ao máximo a pena da culpabilidade, evitando, assim, iniqüidades por parte da Justiça.

Mas se a justiça se apresenta como empreendimento vazio de garantias, como no caso das periferias da cidade, todo esse aparato perde seu potencial, impondo uma inversão. E a não decretação da prisão provisória de um acusado ao invés de uma garantia de liberdade, pode se converter em mais uma ferramenta de coação para as vítimas de violência.

$\mathrm{Na}$ há novidade em recorrer à privação de liberdade como estratégia de proteção. 0 crescimento da violência em São Paulo veio acompanhado pari passu pela demanda social por punição como solução para a crise na segurança pública. O Estado de São Paulo foi eficaz na sua resposta e é possível dizer que nos últimos anos o encarceramento foi a política pública privilegiada do Estado para enfrentar a violência.

O gráfico 11 mostra o crescimento intimidante da taxa de encarceramento e São Paulo, cuja população carcerária já responde por quase $50 \%$ do contingente do país.

\section{Gráfico 11}

$N^{\circ}$ Presos no Estado de São Paulo em Regime Fechado fonte: Depen

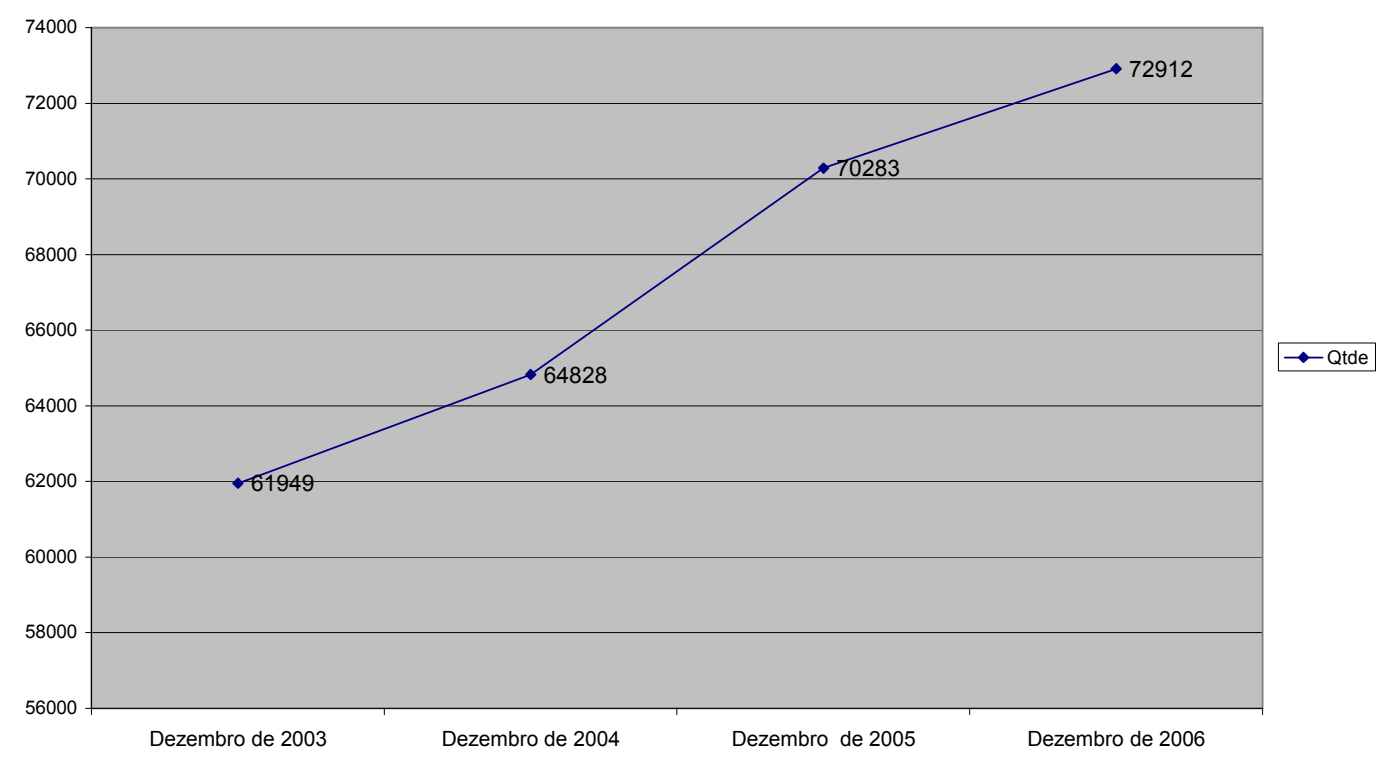


Não se trata aqui de cobiçar mais prisões provisórias ou de uma percepção ingênua de que prender acusados seria a solução. 0 objetivo é expor a encruzilhada: ao mesmo tempo em que o aparato estatal parece armado e disposto a punir, ele não se mostra, na mesma proporção, capaz de proteger.

Se, por um lado, reconhecemos que as políticas repressivas e os atores públicos nesse campo selecionam suas vítimas de modo privilegiado entre essa parcela da população, por outro, não poder acessar aparatos tais como a polícia, as denúncias ou a prisão daqueles que cometem crimes de fato - manter-se longe desse universo repressivo, ou de seus recursos - também vitimiza essa população.

O resultado é que a denúncia de criminosos por parte da população é intimidada porque a Justiça não é capaz de estabelecer uma rede de garantias.

De forma perversa, a prisão de acusados como medida que garantiria a integridade ou mesmo a vida das vítimas e testemunhas acaba ocupando nesse esquema o lugar que deveria ser das políticas de prevenção e enfrentamento da violência.

A sociedade foi eficaz na criação de verdadeiros campos sociais herméticos e impermeáveis, incapazes de tocar ou serem tocados pela justiça ${ }^{146}$.

\section{Gravidez pela mão}

"Aquele ali é o Roberto, ele tem mais de oito filhos espalhados pelo bairro, cada um com uma mulher diferente".

Foi assim que, durante um churrasco na laje da casa de um dos jogadores do time de futebol local, depois de uma partida, minhas duas acompanhantes na festa, esposa e namorada de jogadores do time, descreveram um dos homens ali presentes. Minutos depois o jovem alto, negro, com roupas estilosas estava na nossa frente. Ao ser apresentada a ele estendi minha mão com naturalidade e, imediatamente, escutei gritos altíssimos de ambas, misturados com risadas, dizendo "Não! Não encosta que esse aí você engravida só de pegar na mão".

\footnotetext{
${ }^{146}$ Não há espaço para essas reflexões no trabalho, mas também é interessante notar que, por outro lado, as dificuldades na investigação, resultantes do cenário descrito acima, acabam por justificar, por parte da polícia, métodos que violam os direitos dos acusados. A armadilha é completa.
} 
Hesitei por segundos e concluí o aperto de mão para que Roberto desaparecesse nos próximos minutos, e me deixasse novamente a sós com as duas, que continuavam achando graça naquilo tudo.

Soube posteriormente que as mães dos filhos de Roberto, ao contrário do que eu poderia imaginar, gostavam todas muito dele. Algumas, inclusive, diziam que se pudessem teriam mais filhos com ele. Quando indagadas por quê, minhas acompanhantes disseram que mesmo sem ter certeza, tinham suspeitas sobre suas habilidades no campo afetivo e sexual.

Além do meu constrangimento momentâneo, a piada comigo e Roberto tinha outros significados. De minha parte, foi a primeira vez em que me senti verdadeiramente amiga "das mulheres". Minha entrada no Parque Novo Santo Amaro foi por meio do universo masculino e, até então, era lá que eu havia permanecido. Essa plataforma de sociabilidade não era aleatória, eu convivia em espaços freqüentados quase que exclusivamente por homens ou espaços de autonomia; o bar, os jogos de futebol, a casa de outras pessoas. As mulheres participavam de eventos sociais e visitavam, claro. Mas "aparecer" na casa do outro sem avisar, como eu fazia às vezes, era mais comum em se tratando dos homens.

A circulação das mulheres pelos espaços do bairro, as diferenças entre mulheres casadas e as solteiras, o trabalho, assim como o tipo de trabalho, por exemplo, não eram tópicos de interesse imediato da pesquisa, mas eram temas também fundamentais em se tratando da sociabilidade local e faziam parte da órbita do universo investigado.

Ao mesmo tempo em que a brincadeira condensava várias temáticas, pela primeira vez estávamos falando de um assunto essencialmente feminino, a gravidez. Havíamos evitado o tema até então, ainda que eu fosse uma espécie de exceção absoluta num mundo onde praticamente todas as mulheres tinham filhos. Esse foi um tipo de gancho para que elas pudessem saber um pouco mais da minha vida: entre outras coisas se eu era casada ou tinha filhos.

$\mathrm{Na}$ casa de Marcelo todos tinham filhos. Ele mesmo foi pai quando tinha 17 anos. Sua mulher engravidou quando tinha 16 e, de acordo com as palavras da própria "o Marcelo foi me tirar da casa da minha mãe e eu nunca mais voltei". A manutenção de seu casamento até hoje e ter apenas um filho são diferenciais na vida de Marcelo e do casal, sobretudo na comparação com outros jovens da comunidade. Ser pai de apenas um filho é interpretado positivamente pelo próprio Marcelo que, mas de uma vez, me disse que não quer ter mais filhos, ou que não pode ter mais filhos porque quer "dar o melhor que eu puder para o Felipe". 
A irmã de Marcelo, solteira, também é mãe de um filho. E o irmão de Marcelo, mais novo que ele, teve durante o tempo em que freqüentai mais assiduamente o Parque Novo Santo Amaro, dois filhos. 0 nascimento do primeiro filho foi o que motivou seu casamento com a esposa de quem já se separou e reatou algumas vezes.

Se chama a atenção a quantidade de pessoas vivendo sob um mesmo teto, também chama atenção o quão pouco essa questão é problematizada. 0 espaço privado parece ser pouco valorizado, assim como a noção de propriedade, pelo menos dos espaços da casa que são, necessariamente, compartilhados. Sobretudo quando comparados a outros padrões.

Freqüentei a casa de Marcelo durante todos esses anos sem nunca ter perguntado ou mesmo conseguido imaginar como a família toda se dividia num espaço tão exíguo.

A população da casa ainda é flutuante. Houve épocas em que toda família morava na casa e ainda abrigava um amigo que habitou lá tempo suficiente para deixar de ser classificado como hóspede e ganhar status de morador. 0 irmão depois do nascimento do primeiro filho viveu um tempo com a sogra, para, alguns meses depois, voltar a se estabelecer na casa da mãe.

Não problematizar o espaço que é compulsoriamente compartilhado não ofusca, todavia, o desejo da casa própria. Recentemente, no minúsculo quintal de Joana, o irmão de Marcelo deu início à construção da sua casa. Do ponto de vista físico e quiçá prático, pouca coisa vai mudar uma vez a construção da casa concluída. As casas são coladas e, até onde eu pude compreender, a planta não previa, entre outras coisas, a construção de um banheiro. 0 da casa original continuaria a ser dividido entre os moradores. Assim como os espaços comuns como o próprio quintal, o tanque de lavar roupa e a mesa que ficava do lado de fora da casa a única capaz de abrigar todos para uma refeição conjunta.

Mas ter uma casa sua - mesmo que o sentido de propriedade e privacidade precisem ser relativizados - e deixar a família nuclear é uma aspiração permanente. Faz parte de um conjunto de indicadores de que a vida, mais do que atingir a maturidade, está no caminho certo.

\section{Quem está disputando o que?}

Felipe, filho de Marcelo, tem hoje sete anos e pode ser considerado uma criança privilegiada. Não foram poucas às vezes em que soube das brigas de Marcelo com a professora da escola de seu filho por conta da ausência das aulas ou da sua pouca qualidade. Isso se repetiu com o médico do posto de saúde quando, por exemplo, um diagnóstico equivocado de meningite fez 
com que Marcelo e sua mulher saíssem correndo do posto para enfrentar a fila do pronto socorro de um hospital público por horas, até descobrir que, na verdade, Felipe tinha apenas uma gripe.

Quando não está na escola, Felipe gasta quase todo seu tempo na rua, brincando. Sua mãe procura vigia-lo de longe, e sabe sempre, na medida do possível, onde ele está, com quem está e o que está fazendo. Foi brincando na rua que Felipe ficou amigo de André, uma criança um pouco mais velha que ele, com quem compartilhava seu tempo livre.

Nunca tinha notado André até o dia em que dei um presente para Felipe e semanas depois vi André, mais velho que ele, mas também ainda uma criança, brincando com o presente. $\mathrm{Na}$ hora quis saber quem era aquela criança, se era alguém da família de Marcelo que eu não tinha conhecido ou não estava reconhecendo.

“Ele é largado" me contaram Marcelo e sua mulher. Como assim largado?

André é órfão, seu pai morrera "há muito tempo" e a mãe, depois disso, o abandonou. Ninguém tinha mais detalhes da história, mas era fato que o menino passava os dias na rua, brincando com as outras crianças, dormindo eventualmente na casa de Marcelo. Quando isso não acontecia, já de noite, voltava para "casa”, que era razoavelmente longe dali, onde era cuidado por um homem que, segundo Marcelo e sua esposa, tinha ligação com o crime. Parecia ser de conhecimento de todos que esse homem havia informalmente adotado 0 menino.

André estava fora da escola há muitos anos e, de acordo com Marcelo, eles tiveram notícia de que ele estava cometendo pequenos delitos.

Em janeiro de 2007, quando estive no bairro para uma feijoada de aniversário da mulher de Marcelo, soube que eles, a família, haviam decidido adotar André. Na verdade, diante dos pequenos furtos cometidos pelo jovem, Marcelo resolveu intervir, antevendo uma carreira no crime.

A casa, que já acomodava um número excessivo de pessoas, passou a abrigar também André. 0 acordo entre Marcelo e André era de que o menino seria matriculado na escola, poderia morar com a família, ainda que nas palavras de Marcelo, ele não tivesse muito para oferecer a ele. Como contrapartida, André teria que freqüentar a escola, se dedicar aos estudos, teria que se comportar e teria horário de voltar para casa. Segundo o próprio Marcelo, era "uma chance" que ele estava dando ao jovem. 
Eu nunca soube a idade exata do garoto, mas nessa época, quase dois anos haviam se passado desde quando eu o havia visto pela primeira vez e André não era mais uma criança, mas quase um adolescente.

O entra e sai de pessoas e o fato de que quando eu estava lá ficávamos pouco na casa, propriamente (diversas vezes nos visitávamos nos bancos da praça em frente), contribuíram para que eu nunca tivesse me questionado se André estava de fato morando com eles.

Cerca de quatro meses depois numa nova visita à casa de Marcelo, perguntei como estavam as coisas e ele me disse que o menino já não morava mais com eles.

Uma sucessão de acontecimentos fez com que Marcelo e sua família decidissem encerrar a nova adoção informal do garoto. O sumiço inexplicado de dinheiro deixado junto a uma muda de roupa foi o que detonou a desconfiança de toda família. Ainda nessa ocasião, Marcelo tomou partido de André e decretou o assunto por encerrado, ainda que o dinheiro nunca tivesse sido encontrado.

Algum tempo depois, uma das escolas do bairro foi assaltada. Os assaltantes não levaram nada de muito valor, apenas muitos rolos de fios que estavam lá para serem usados na manutenção do espaço. Pessoas da comunidade disseram ter visto André no grupo de meninos que praticou o assalto.

Finalmente, em maio do mesmo ano, na semana que antecedeu a visita em que descobri que André já não morava mais com a família de Marcelo, o jovem apareceu em casa com um celular. Quando questionado sobre como havia conseguido o aparelho, respondeu que havia ganhado o aparelho, mas não conseguiu explicar de quem nem como. Na mesma semana o celular tocou e a mulher de Marcelo atendeu. Do outro lado falava supostamente o dono do aparelho, dizendo que seu celular havia sido roubado. Marcelo conversou com André que negou o roubo, mas também não se dispôs a dar muitas explicações adicionais. Ambos estavam já desgastados pelos sucessivos episódios e o "crime" havia se tornado um assunto concreto pela primeira vez.

As boas intenções de Marcelo e de sua família não foram suficientes. O ambiente de desconfiança havia se consolidado como um obstáculo a qualquer laço que pudesse ser criado e depois de uma conversa com André, Marcelo disse que ele não poderia mais morar com eles.

Em seu livro recente, Luiz Eduardo Soares, em parceria com o Rapper MV BIll e o empresário Celso Atayde ${ }^{147}$ procura, recompondo as etapas de formação e transformação identitária,

${ }^{147} 2005$. O livro é um projeto coletivo, mas os ensaios que formam o conjunto são de autoria individual. Os artigos citados a seguir são de autoria exclusiva da Luiz Eduardo Soares. 
recuperar aquilo que chama de processo de "invizibilização" das crianças e jovens envolvidos com o tráfico de drogas e outras formas de crime organizado. 0 argumento de Soares parte do suposto de que "indiferença gera invisibilidade" e que, portanto, o engajamento desses jovens com o crime seria uma das possibilidades de romper essa condição ${ }^{148}$.

Chamando também a atenção para a multiplicidade do fenômeno da violência, o autor elege o crime organizado, envolvendo o tráfico de armas e drogas, como pano de fundo para suas reflexões. Refaz a trajetória desses jovens por meio de uma pesquisa de campo nacional que, no entanto, privilegia o caso carioca. A constituição da invisibilidade desses meninos resultaria da associação entre preconceito e indiferença com as quais os jovens pobres, moradores das favelas, em sua maioria negros, seriam tratados pela sociedade. Com efeito, estaríamos projetando e construindo uma só imagem a respeito desses jovens - violentos e ameaçadores, sempre algozes, mas nunca vítimas. Eles, por sua vez, responderiam a essa construção num movimento duplo que tenta romper a invisibilidade de muitas maneiras, mas, ao mesmo tempo, incorporar esse legado identitário ao seu comportamento, concretizando aquilo que o autor identifica como uma "profecia que se autocumpre"149.

O envolvimento com o crime seria, então, uma associação entre duas dinâmicas. Por um lado, estamos falando de uma tentativa de romper essa invisibilidade, incorporando padrões coletivos de comportamento e fazendo parte de um grupo armado organizado; o que enfatizaria o sentimento de pertencimento e, portanto de reconhecimento. Por outro lado, há também uma dimensão mais individual do fenômeno, envolvendo situações de privação, marginalização social, desejos relacionados a padrões inalcançáveis de consumo, medo e busca por respeito.

Não é possível, claro, ignorar o contexto onde tais relações são travadas. 0 autor faz um apanhado de certas determinantes a fim de reconstruí-lo. Entre elas estão a adolescência e as dificuldades e incertezas que cercam essa etapa da vida, a geografia da cidade carioca, além dos "laços prováveis", nas suas palavras, entre pobreza, menor escolaridade, menor acesso a oportunidades de trabalho, alcoolismo, violência intrafamiliar ${ }^{150}$. Esse conjunto de condições estabelece um ciclo onde os resultados possíveis da combinação entre tais elementos gerariam dificuldades maiores no interior da família, uma tendência a abandonar a escola e a conseqüente redução das chances no mercado de trabalho. Soares procura, portanto,

\footnotetext{
${ }^{148}$ Idem: 215.

149 Ibidem: 209.

150 Ibidem: 209.
} 
desenhar um caminho cujo ponto final pode ser (ou não), o envolvimento com a criminalidade ${ }^{151}$.

Com efeito, podemos dizer que o engajamento num grupo do crime organizado seria, sobretudo, uma resposta a essas determinantes. Ele é, no entanto, uma reposta pró-ativa. Isto é, se, como vimos, esses jovens são indiscutivelmente vítimizados por condições sócioeconômicas adversas, eles são também protagonistas dessa parábola e estão respondendo de maneira violenta a ela.

O trajeto reconstruído por Soares projeta a questão da identidade para o centro do debate. Como sabemos, as relações são arenas privilegiadas na negociação de identidades e, portanto, estamos falando essencialmente de um processo social e histórico. Nesse processo de constante negociação fica claro que e porque as identidades não são únicas, exclusivas, tampouco constantes. Identidades são construções e, nesse sentido, são elaboradas a partir de uma perspectiva e repertório individuais, mas exigem uma interação com "o outro". Ou seja, tal construção só se realiza por completo na medida em que é reconhecida pelo outro, ou por muitos outros.

Soares associa identidade ao pertencimento, enfatizando seu potencial produtor de semelhança e aproximação. “Quem é algo, é sempre algo para os outros; e quem é algo para outros, relaciona-se com eles e participa, com eles, de alguma experiência gregária. Eis aí o grupo, no meio da cena, justamente quando esperávamos o indivíduo em seu momento de

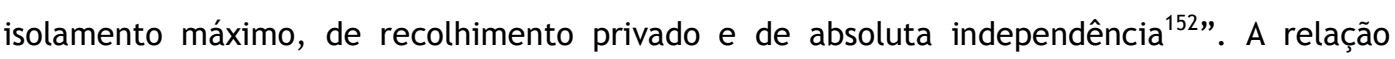
entre essas duas qualidades, assume um papel de elemento potencializador na formação de grupos e, assim como na pesquisa de Dowdney ${ }^{153}$, parece um caminho interpretativo para compreender a formação de grupos jovens armados, e o ethos que os cerca.

A bibliografia que trata do engajamento do jovem na criminalidade sob a ótica do respeito é bastante extensa e faz referência, sobretudo, ao cenário carioca, onde o crime organizado, de maneira concentrada o tráfico de drogas, vem aliciando e vitimizando jovens aparentemente de maneira irrestrita.

Alba Zaluar ${ }^{154}$, pioneira nos estudos nesse campo e precursora também nas interpretações sobre a dimensão simbólica na história de vida desses jovens, mostra como a imagem e o

\footnotetext{
${ }^{151}$ Ao mesmo tempo em que aponta esses elementos, o autor também problematiza a "criminalização da pobreza", e os estigmas que ela pode produzir. Ressalta, contudo, que não é possível negar tal associação por completo.

${ }^{152}$ Soares, 2005: 207.

1532005.

154 Zaluar, 1998.
} 
papel social do bandido e membro das quadrilhas atuantes nos morros cariocas se constroem muito mais vinculados a valores como o fascínio e o status advindo da posse de armas de fogo, a posição de destaque e de poder que essa condição os coloca na rede de relações sociais locais, bem como o próprio orgulho masculino que se configura nesse processo, do que pelo status de vítima de uma condição socioeconômica específica. "Atraídos por essa identidade masculina, os jovens, nem sempre os mais destituídos, incorporam-se aos grupos criminosos em que ficam à mercê das rigorosas regras que proíbem a traição e a evasão de quaisquer recursos, por mínimos que sejam ${ }^{155}$ ". Em outras palavras, ao reconstruir a rede que envolve os diversos níveis de hierarquia do "mundo do crime" do morro separando "os laranjas, dos cabeças, dos vapores", a autora mostra como a imagem do crime e do poder que se constroem nesse contexto, são atributos de status num universo particular. Além do poder concreto de controlar uma área do morro e enriquecer as custa do tráfico, há o poder simbólico que carregar uma arma, matar e ser respeitado proporcionam.

“Entre os rapazes ou meninos, o principal motivo de orgulho advém do fato de que fazem parte da quadrilha, portam armas, participam das iniciativas ousadas de roubos e assaltos, adquirem fama por isso e podem, um dia, caso mostrem 'disposição para matar', ascender na hierarquia do crime ${ }^{156 "}$.

Mais importante, no entanto é que, como bem aponta a antropóloga, "se juntar a uma quadrilha” não pode ser entendido como uma conseqüência das determinações da pobreza e da exclusão social, já que da mesma maneira que alguns jovens fazem essa opção, muitos outros escolhem o funk, o pagode, o futebol ou qualquer outro tipo de referencial de grupo. Mais de uma vez o envolvimento dos jovens com a criminalidade foi colocado nos termos de uma competição: a sociedade, a família, o governo e as políticas devem disputar (e preferencialmente ganhar) o jovem com o tráfico ou com o crime organizado de modo geral. Secretários de governo em diferentes níveis, alguns pesquisadores e, mais recentemente, o Ministro Especial de Direitos Humanos, Paulo Vanucchi, ao apresentar novos programas sociais $^{157}$, já afirmaram que é nesse campo de batalha que temos que "disputar com o tráfico menino a menino".

Até então a trajetória de André era um pouco mais ambivalente do que o envolvimento com uma quadrilha, mas sua história nos ensina que se a idéia de disputa ganha algum sentido, ela deve ser entendida de maneira muito mais ampla. As arenas de embate são muitas e mais

${ }^{155}$ Zaluar, idem: 294.

${ }^{156}$ Ibidem: 295.

${ }^{157}$ O Globo, 20.3.2006. 
variadas do que aquelas contidas na oposição vida no crime $x$ vida "pelo certo". André não freqüentou a escola ou freqüentou muito pouco, sua história familiar se resume a uma trajetória de desamparo, sua ligação mais próxima, o homem com quem ele morava antes e depois da adoção por parte de Marcelo - algo que poderia ser visto como um laço familiar - é uma pessoa envolvida com o crime. A tentativa de acolhimento numa família é duplamente frustrada: de um lado, André não consegue cumprir o combinado e volta a se envolver com pequenos delitos; de outro, a família que o adota não tem estrutura e ferramentas para lidar com a situação e opta por mandá-lo embora. A simples idéia de impor regras em troca do acolhimento familiar e a promessa de um futuro melhor não foram capazes de fazer um contrapeso na balança.

Nesse sentido, fica claro que não há como competir com nada nem com ninguém se o próprio jovem está completamente desarmado para disputar sua vida, suas aspirações e seus desejos. Luiz Eduardo Soares já alertava que os alvos dessa disputa deveriam ser o "coração e a cabeça dos jovens ${ }^{158}$ ".

Arjun Appadurai, identifica na "capacidade de aspirar"159 um aliado fundamental ao desenvolvimento. No ensaio "The capacity to aspire: culture and the terms of recognition" seu argumento concentra-se na relevância da cultura não apenas para o desenvolvimento, mas também para a redução da pobreza ${ }^{160}$.

Para Appadurai, a capacidade de aspirar é uma instância específica da cultura e, com efeito, compartilha com ela sua natureza social. Desse modo, o antropólogo indiano ressalta como as aspirações são socialmente determinadas.

Mas, de acordo com o autor, a cultura referencia o passado, evocando, por exemplo, as idéia de hábito, tradição, herança e costume. 0 desenvolvimento, ao contrário, tem seus princípios elaborados no futuro, ou pelo menos na idéia de futuro. Os termos para pensar em desenvolvimento ou mesmo caracterizá-lo, são planos, esperanças, objetivos, alvos.

Minha pesquisa anterior, com internos da FEBEM, mostra como o crime ocupa um lugar intercambiável na trajetória de vida dos jovens cumprindo a medida de internação. Traduzido num discurso que ora valoriza a atividade criminosa e todos os benefícios e riscos reais e imaginários associados a ela, ora valoriza um futuro longe do "veneno". Além de uma evidente identidade em eterna construção, a alternância entre esses papéis ou entre a

${ }^{158}$ Op.Cit: 241.

${ }^{159}$ A expressão original em inglês é "capacity to aspire" (Appadurai, 2004: 64).

160 2004. Appadurai não deixa de apontar a complexidade da categoria "cultura" para antropologia e suas muitas definições na história da disciplina. O autor, no entanto, elege uma dimensão da cultura "a sua orientação para o futuro" como pretexto para sua reflexão neste ensaio. 
disposição para delinqüir pensada para além dos temos do bem e do mau ou do certo e do errado, constrói para esse jovem um lugar onde ele é capaz de fazer escolhas. Claro, diante de um repertório limitado.

Uma das conclusões do trabalho sobre a Fundação e o universo do jovem em conflito com a lei é que "a Febem falha na sua proposta educacional. 0 grande equívoco é imaginar que a experiência de internação tenha que ensinar que o 'crime não compensa' quando, na verdade, ela poderia ensinar que talvez existam outras alternativas que compensem mais que o crime ${ }^{161 "}$.

Na época em que trabalhávamos na mesma ONG, Marcelo e eu, por acaso, acabamos fazendo um pequeno filme caseiro que trazia, entre outras coisas, entrevistas com jovens da Zona Sul. Nosso roteiro era extremamente simples: perguntávamos a esses jovens quais eram sues medos.

Medo de não ser feliz, medo de não arrumar um emprego, medo de não entrar na faculdade, medo de repetir a história dos pais, foram as respostas mais comuns. Em nenhum momento “medo da violência”, em qualquer formato, apareceu. É como se os medos estabelecessem um diálogo complementar com as aspirações.

Pensado num contexto de privação de natureza diversa, "aspirar" ganha um significado ainda mais poderoso. Creditar ao jovem a capacidade de aspirar e fazer escolhas, mesmo que diante desses cenários adversos, é acreditar que ele pode fazer outras escolhas além do crime. Já sufocar a “capacidade de aspirar” é uma sentença que limita tais possibilidades.

\section{Suicídio induzido}

No final da pesquisa, numa conversa com uma liderança comunitária da Zona Leste, ela comentava do aumento de casos de "suicídio induzido". Minha interlocutora, que trabalha num projeto de intervenção cujo foco são jovens em "situação de risco", conta que tem ouvido histórias cada vez mais freqüentes dessa nova modalidade de assassinato. 0 crime organizado, em geral o tráfico de drogas, ao invés de simplesmente matar seus desafetos ou seus devedores, estaria dando a eles uma opção.

${ }^{161}$ Miraglia, 2001:123. 
Nesse novo quadro, a morte como desfecho segue inevitável, mas a vítima teria opções: ela pode se matar e com isso morreria apenas com um tiro. Ou, se ela não quiser, eles se ocupariam da morte, mas fariam isso de uma maneira mais atroz e cruel, mutilando o corpo, decapitando a vítima, espalhando os pedaços, o que - no mínimo - dificultaria o reconhecimento do cadáver e provocaria mais sofrimento aos familiares. Em outras palavras, não seria uma morte digna. A primeira opção, no entanto, resolve o conflito da mesma maneira, já que a vítima é morta, mas não cria problemas com a polícia e para aquele que matou (já que a morte, nessas condições, não se configura como homicídio).

Se tomada na sua dimensão pragmática, a estratégia faz sentido. Resume a idéia de manobra tática. Porém, como deixar de fora a dimensão moral da reflexão?

Induzir um suicídio retrata a sofisticação da violência, assim como a criatividade incessante das suas práticas, fazendo com que seja inevitável a pergunta sobre quais seriam os limite para a crueldade.

Vimos, desde o início do trabalho, que não é possível explicar todos os homicídios responsabilizando o crime organizado. Ao mesmo tempo, seria ingênuo negligenciar seu papel por completo. Sabemos que o tráfico de armas e de drogas existe e se concentra nas periferias da cidade de São Paulo.

Partindo desse contexto, a tônica das relações que envolvem o crime organizado - tais como medo, ameaça, imediatismo e vingança - parecem ter transbordado as relações diretamente ligadas a ele para imprimir novos padrões de sociabilidade local. De acordo com esses novos padrões, há uma privatização da resolução dos conflitos e da morte, que ainda choca, mas é aceita e faz sentido, sendo, muitas vezes o único modo aparentemente capaz de resolver o problema, seja ele qual for.

Com efeito, podemos tomar o crime organizado ou semi-organizado como flexibilizador de regras, como uma nova gramática de violência que acaba suplantando os limites da sua atuação, para tornar-se o padrão das relações cotidianas. Teríamos, portanto, um híbrido: uma sociabilidade em construção, um meio termo que combina esses dois modelos do "certo" e do "errado", do crime e da lei, materializado na clareira deixada pela ausência das garantias da justiça.

Assim como a violência se desdobra em versões e graus variados, ela também pode ser percebida e tolerada de maneiras diversas. Nesse sentido, aprender a conviver com a violência significa, antes de mais nada, reconhecê-la na sua multiplicidade, mas também 
incorporá-la em alguma medida, o que implica ser capaz de dialogar com ela, proteger-se e responder a ela. 


\section{Capítulo 3}

\section{Redes, Juventude e Criminalidade}

“É bem Febem, não é?”

Foi assim que Francisco qualificou, rindo, o presente que acabava de me dar: uma escultura em papel azul e branco, que ele mesmo havia feito, com pequenos origamis que, encaixados uns nos outros, formavam a figura de um pato. A referência era irônica, mas precisa. A peça é exatamente o tipo de "artesanato" que jovens aprendem a fazer nos chamados cursos profissionalizantes oferecidos aos internos da Febem.

Essa era a segunda vez que nos encontrávamos. Conheci Francisco por intermédio de Marcelo, numa tarde em que conversávamos na praça. Ambos, entretanto, não se definiriam como amigos. São conhecidos, vizinhos, se encontram nos eventos locais. Mas como o fazem há muito tempo, já que assim como Marcelo, Francisco, que tem 24 anos, morou toda a sua vida no Parque Novo Santo Amaro. Há, portanto, certa intimidade entre os dois.

No nosso primeiro encontro a conversa girou em torno de dois tópicos. A razão das minhas visitas constantes - o eterno tema com qualquer interlocutor local -, e meu gosto literário. Nessa época eu estava combinando a entrega da doação de livros para a biblioteca comunitária. Minha reunião com Seu João, presidente da Associação de Moradores, para definir a data e o armazenamento dos livros enquanto as estantes não ficavam prontas, acabou pautando minha conversa com Francisco, que presenciou todo o diálogo e ainda se ofereceu para ajudar.

O jovem era um grande leitor, gostava especialmente de Clarice Lispector. Na minha próxima visita, em retribuição ao pato de papel, levei para ele um exemplar de "Abril Despedaçado" de Ismail Kadaré.

Assim como Marcelo, Francisco também mora perto do campo de futebol. Mas sua casa fica do lado oposto, vizinha à Associação de Moradores e do bar do Wilson, numa das extremidades do que deveria ser o gramado. Seus pais já não são mais casados e ele mora com o pai e um dos irmãos. Segundo o próprio, ele tem vários irmãos espalhados pelo bairro.

Nos encontramos diversas vezes desde então. Em todas elas Francisco estava extremamente arrumado. Suas roupas eram impecáveis, o cabelo com gel, a moto brilhando. Tudo isso contrastava com o cenário ao redor. Suas baladas eram sempre fora do bairro. Ele me contava 
sobre os lugares no "centro" que freqüentava: geralmente bares na Vila Olímpia ou em Moema. Francisco achava graça no fato de que eu não conhecia nenhum dos lugares que ele freqüentava. Assim como ele não era o morador da periferia que eu havia imaginado, eu provavelmente também não era a moradora do "centro" que esperava encontrar.

A despeito da sua referência à Febem, Francisco nunca esteve internado, ou preso, ou teve qualquer envolvimento direto com o crime. Na verdade, logo quando nos conhecemos, ele me foi descrito como um "resistente". Isso porque sua família inteira estava no crime, mas ele não. Seu pai é um criminoso local (informação que eu soube por outras pessoas já que nós nunca conversamos sobre o tema). Alguns dos seus irmãos, frutos dos relacionamentos de seu pai com outras mulheres que não sua mãe, também estão envolvidos com o crime. Mas ele não: tem um emprego fora do bairro. Trabalha numa empresa de seguros, segundo suas próprias palavras, "no setor administrativo".

Deixando de lado seu gosto pelas baladas mauricinhas, Francisco reproduz um padrão comum de sociabilidade: vive perto do crime - no seu caso "perto" é radicalizado, uma vez que trata-se da família com quem mora até hoje - mas não tem nenhum envolvimento profissional ou formal com ele.

Essa oscilação entre proximidade e distância com o crime pode ter muitas versões e gradações. Como a história aparentemente contraditória que me foi contada do jovem, que nunca cheguei a conhecer, que financiou os cinco anos do seu curso de Direito, numa universidade particular com dinheiro de roubo de carga. Ao final do curso, ele estava enfrentando dificuldades para se desligar do crime organizado e entrar no mercado de trabalho legal, onde tinha a esperança de exercer sua profissão. Ou o caso de um conhecido, também morador da Zona Sul, que encontrei por acaso, justamente quando ele voltava orgulhoso da matrícula no curso de Ciências Sociais na PUC-SP (Pontifícia Universidade Católica de São Paulo). Conversávamos sobre as perspectivas do curso e das possibilidades de bolsa, quando ele me contou que para a matrícula, que na época girava em torno de $\mathrm{R} \$ 700,00$, como não tinha esse dinheiro, foi pedir ao pessoal do "movimento". Ele estava se referindo ao pessoal do tráfico de drogas que fez questão de pagar a matrícula (dinheiro que, claro, ele teria que devolver) e ainda "desceu para praia em Santos" a fim de comemorar com ele o ingresso na universidade.

Paradoxalmente, ao mesmo tempo em que não resta dúvida sobre quem é do crime e quem não é, não é possível ignorar que se estamos falando de dois universos, estamos falando também de pessoas que se conhecem, co-habitam espaços, convivem, cresceram juntas, e eventualmente são amigas até hoje. Com efeito, se os limites entre os de dentro do crime e os de fora são 
evidentes, as fronteiras entre o legal e o ilegal não parecem ter a mesma precisão, criando um terreno nebuloso.

Como mostra o capítulo anterior, esses padrões de sociabilidade, "a lei do crime", podem transbordar os limites de atuação do crime organizado de muitas maneiras. Aqui interessa mostrar como esse campo onde a proximidade e distância do crime estão em constante oscilação, faz com que jovens moradores de áreas pobres ou periféricas, em geral - a partir de um modelo genérico e estigmatizante de criminoso: jovem, pobre, não-branco- sejam vistos como criminosos em potencial. Francisco, por exemplo, mora um bairro pobre, extremamente violento, é pobre, não branco, convive com o crime no interior da sua casa. Em suma, reúne todos os pré-requisitos, mas trabalha na seguradora.

Diante do crescimento dos indicadores de violência urbana, o envolvimento dos jovens com a criminalidade tem ocupado um lugar central no debate sobre violência urbana não apenas no Brasil, mas em países com graus diversos de desenvolvimento econômico e social ${ }^{162}$. Em geral, tais estudos partem do suposto de que há uma ligação entre a juventude envolvida com a criminalidade, sobretudo a violência à qual estão submetidos, e sua condição de vulnerabilidade social. Seu acesso prejudicado às estruturas de oportunidades nos campos da educação, saúde, educação, trabalho, cultura e lazer acabam por comprometer seus processos de integração social. Os resultados desses processos mal conformados são variados, mas entre eles está a sujeição de uma parte desses jovens a um cotidiano com altas doses de violência.

Esse capítulo pretende, por meio de dados quantitativos, reconstruir o percurso social do envolvimento do jovem com o universo da criminalidade, assim como a incorporação da violência e da própria criminalidade como padrão e referência nas suas relações sociais. Para tanto, usa dados referentes ao universo dos jovens cumprindo medidas sócio-educativas e que, portanto, foram julgados e culpados pela Justiça pela prática de um ato infracional ${ }^{163}$. Parte de um

${ }^{162}$ Adorno, Lima, Bordini, 1999;Cardia, 1998; Gregori, 1997; Zaluar, 1994c; Feffermann, 2006; Assis, 1999, entre outros. Entre os exemplos internacionais, pode citar Rodgers (2003), que, a partir de etnografias comparativas, analisa as transformações das gangues juvenis na Nicarágua, e de que maneira a atuação de tais grupos refletem as mudanças nos padrões de violência local ao longo dos anos. Dowdney (2005) apresenta um estudo comparativo global sobre o envolvimento de crianças e jovens com a violência armada organizada. Finalmente, Barker (2005), parte de um estudo comparativo entre Brasil, EUA, Uganda, Nigéria e Caribe, para revelar como referências de um determinado modelo de masculinidade são determinantes fundamentais para que, nesses países, as principais causas de morte para jovens do sexo masculino sejam os homicídios, os acidentes de carro e HIV/AIDS.

${ }^{163}$ Segundo o artigo 103 do ECA, ato infracional é a conduta tipificada como crime ou contravenção penal quando cometida por jovens com menos de 18 anos. Substituir "crime" "por ato infracional" é importante em muitos níveis, mas, sobretudo, por que ao invés da pena, o ato prevê uma medida sócioeducativa, mas apropriada, também de acordo com o ECA, ao processo de reeducação e reinserção social do jovem. Do ponto de vista da conduta, ambos descrevem a mesma coisa. Na minha dissertação (Miraglia, 2001), mostro como o termo "ato infracional" fica restrito ao universo da justiça. Para os internos estamos sempre falando de crimes. 
levantamento mais geral - um mapeamento nacional sobre a situação de internação - para fazer um retrato mais detalhado sobre o perfil de jovens cumprindo medidas em meio aberto.

Os dados possibilitam uma reflexão sobre alguns condicionantes contextuais ligados ao envolvimento dos jovens com a criminalidade, trazendo elementos capazes de iluminar a construção de um caminho que proporciona essa aproximação com a violência, além das bases materiais, sociais e políticas para a produção e reprodução da violência.

\section{Um Raio X da infração}

Se é possível afirmar que há uma associação corrente entre juventude e criminalidade seja no plano simbólico, seja no plano concreto, esse é um universo demasiado grande e variado quando considerado o repertório de contextos onde essas duas categorias podem se encontrar.

A participação dos jovens na criminalidade urbana é objeto controverso onde estão constantemente em disputa os lugares de vítima e de autor. $\mathrm{O}$ quanto isso de fato corresponde à realidade revelada pelos dados, contudo, não está claro. Mas ser fiel àquilo que chamamos de realidade tampouco é simples. A equação confronta as estatísticas criminais com a brutalidade dos crimes que se tornam conhecidos do grande público. Soma-se a isso a sensação de insegurança que é por si só um duplo da realidade já que, como vimos, os riscos não são democráticos na maneira pela qual se distribuem entre o conjunto dos cidadãos.

O episódio no Rio de Janeiro, em fevereiro de 2007, no qual um garoto de cinco anos foi arrastado alguns quilômetros por um carro dirigido por um grupo de homens que acabava de assaltar a família da criança, resultando na sua morte, tornou-se um marco recente da dramaticidade do quadro de violência urbana no país.

A repercussão do crime de uma maneira geral - incluindo a indignação das autoridades e da população, além da sua associação com o grau intolerável de violência urbana - esteve concentrada, quase que exclusivamente, no debate relativo à redução da maioridade penal. 0 Governador do Estado do Rio de Janeiro, Sergio Cabral, numa de suas primeiras declarações após o crime, disse que era necessário rever a legislação ${ }^{164}$, medida que não está na esfera de atuação do Governo Estadual. O crime também foi o detonador da retomada da discussão no Congresso e no Senado que culminou com a aprovação, em primeira instância, por parte do Senado Federal da redução da idade penal para 16 anos.

${ }^{164}$ Folha de São Paulo, 13.02.2007. 
No entanto, entre os quatro acusados, apenas um era menor de 18 anos. Mesmo assim, qualquer outra possível abordagem relacionada ao evento ficou ofuscada diante do tema da impunidade e do envolvimento dos "menores" com a criminalidade.

A percepção de que o Estatuto da Criança e do Adolescente é uma lei branda, inadequada e um verdadeiro instrumento a serviço da impunidade, explica em parte essa percepção da realidade, bem como a seletividade na escolha dos culpados. Mas essa é uma leitura equivocada, uma vez que, tecnicamente, o ECA tem sim uma dimensão punitiva e do ponto de vista legal pode, em alguns casos, impor mais constrangimentos e ser mais severo do que o próprio Código Penal ${ }^{165}$. Além disso, as condições das unidades de internação e a violência - física e simbólica - a qual os jovens estão submetidos no seu interior não permitem outra percepção a não ser a de que são verdadeiros infernos.

Mas, a despeito da sua maturidade, (o ECA tem hoje 17 anos), a legislação ainda é alvo de debates polêmicos, sujeita a ataques e tentativas de alterações. Trata-se, porém, de uma legislação extremamente desgastada, sem nunca ter sido aplicada na sua plenitude.

Nessa reflexão é preciso considerar que, ao longo dos anos, enquanto se desenhava essa verdadeira batalha por culpados - a lei, os jovens, a sociedade - os internos, assim como as próprias unidades de internação, converteram-se em grandes símbolos da criminalidade urbana.

O Estatuto da Criança e do Adolescente prevê sete possibilidades de medidas sócio-educativas.

De acordo com o Art. 112. "Verificada a prática de ato infracional, a autoridade competente poderá aplicar ao adolescente as seguintes medidas":

\section{I - advertência; \\ II - obrigação de reparar o dano; \\ III - prestação de serviços à comunidade; \\ IV - liberdade assistida; \\ $V$ - inserção em regime de semi-liberdade;}

\footnotetext{
${ }^{165}$ Para uma análise da dimensão punitiva do ECA, cf. Miraglia, Sposato (2007). O rigor e as distorções do Estatuto podem ser percebidos nos seguintes exemplos: a regra de liberação do adolescente apreendido mediante a presença da família, o que seria equivalente ao relaxamento da prisão para o adulto, não acorre; o tratamento dispensando pela Justiça caso o adolescente tenha cometido um ato infracional leve ou grave é praticamente o mesmo. Na Justiça da infância e da juventude, não se reconhece o princípio da presunção da inocência. Enquanto um adulto pode responder em liberdade, o adolescente, que é inimputável, permanece preso. Um adulto pode ter seu habeas corpus julgado a tempo, já o adolescente cumpre a medida integralmente sem nenhuma manifestação da instância superior. Finalmente, enquanto o adulto pode apelar em liberdade da sentença condenatória, o adolescente já está preso, de antemão, é considerado

culpado.
} 
$\mathrm{VI}$ - internação em estabelecimento educacional;

VII - qualquer uma das previstas no art. 101, I a VI.

Ainda segundo o Estatuto, a medida determinada ao adolescente deve observar uma correspondência entre a gravidade da infração e a medida aplicada, e levar em conta sua capacidade de cumpri-la.

A internação só se justifica quando "tratar-se de ato infracional cometido mediante grave ameaça ou violência a pessoa; por reiteração no cometimento de outras infrações graves; por descumprimento reiterado e injustificável da medida anteriormente imposta." O Estatuto ainda é claro quando diz que a internação jamais deve ser aplicada quando houver uma medida mais adequada. A adequação da medida carrega grandes doses de subjetividade combinadas e deve ser considerada em conjunto com as limitações do ponto de vista da execução. Além da compreensão do juiz sobre o caso, há também a qualidade e disponibilidade dos programas para receber o jovem infrator que, combinados, acabam também sendo determinantes na escolha da medida a ser aplicada pelo juiz. Essa observação do ECA procura enfatizar o caráter excepcional da medida de internação prevendo que ela deve ser sempre substituída por outra que possa cumprir seu papel sócio-educativo sem privar o jovem de liberdade, uma vez que o artigo 121 do ECA determina que "a internação constitui medida privativa da liberdade, sujeita aos princípios de brevidade, excepcionalidade e respeito à condição peculiar de pessoa em desenvolvimento".

Para diferenciá-la da pena, prevista no Código Penal, a medida quando aplicada, não tem prazo de duração, devendo ser reavaliada a cada seis meses. Ainda de acordo com o ECA a internação não poderá nunca exceder o período de três anos, sendo que aos 21 anos o jovem recebe a liberação compulsória. A liberação todavia, compreende um processo de transição: o adolescente ao ser liberado, passa automaticamente a cumprir uma medida de semi-liberdade ou de liberdade assistida.

Sem entrar no amplo debate acerca do lugar da especificidade que o $\mathrm{ECA}^{166}$ cria e reserva aos menores de 18 anos, essa brevíssima revisão do Estatuo no que diz respeito ao ato infracional, pretende apenas salientar os aspectos de gravidade e excepcionalidade da medida de internação. Esse é um pano de fundo fundamental para interpretarmos os dados relativos aos jovens internados e pode, assim, contribuir para uma compreensão mais apurada do universo dos crimes considerados graves, cometidos por jovens com menos de 18 anos no Brasil.

Dados do relatório da pesquisa realizada pelo IPEA ${ }^{167}$, a pedido do Ministério da Justiça, retratam um universo de internados de aproximadamente 10 mil adolescentes em todo Brasil. Esse número

\footnotetext{
${ }^{166}$ Para esse debate ver, entre outros, Marques, 1999; Sposato, 2006; Miraglia, 2001.

${ }^{167}$ IPEA, 2002.
} 
é pouco significativo quando considerada a população do país compreendia na faixa etária entre 12 e 21 anos (idades mínima e máxima para internação), cerca de 33 milhões.

Ainda de acordo com o relatório, 90 \% desse total são do sexo masculino, a maior parte, $76 \%$, com idades entre 16 e 18 anos, sendo $60 \%$ negros ${ }^{168}$. Na época em que cometeram o delito, metade dos jovens (51\%) não freqüentava a escola, nem trabalhava (49\%). Viviam com a família (81\%). Quase 50\% dos jovens não havia concluído o ensino fundamental. 85,6\% afirmaram serem usuários de drogas: maconha em $67,1 \%$ dos casos, a cocaína ou o crack em $31,3 \%$, e o álcool em $32,4 \%$.

Sobre os atos infracionais cometidos que resultaram na internação, a pesquisa traz a seguinte distribuição: os homicídios correspondem a $18,6 \%$ dos casos, $29,5 \%$ foram internados por roubo $14,8 \%$ por furto e $8,7 \%$ em função do tráfico de drogas.

Em São Paulo, a Fundação CASA (Centro de Atendimento Sócio-Educativo ao Adolescente) ${ }^{169}$, realizou uma pesquisa em 2006, a partir da qual traçou um perfil de seus internos. A Fundação tinha, em maio de 2007, 21.595 jovens cumprindo medidas sócio-educativas. Desse total, 4.592 estavam na época internados ${ }^{170}$. São Paulo concentra, portanto, quase que a metade dos casos de internação do país.

O perfil foi elaborado a partir de 1.190 entrevistas, realizadas com jovens sorteados aleatoriamente. Do total dos entrevistados, $96 \%$ eram do sexo masculino, o que para além da aleatoriedade da amostra, reflete a proporção de jovens do sexo feminino que estão cumprindo medida de internação. Hoje, em São Paulo, pouco mais de 3\% do total de internos da Fundação CASA são meninas ${ }^{171}$.

Os dados selecionados aqui descrevem um breve perfil social dos jovens, além da sua relação com o universo infracional. A idade média dos internos é 16,7 anos, sendo que $22 \%$ do total têm

\footnotetext{
${ }^{168}$ A classificação "negros" é do próprio IPEA que utiliza, inclusive, o termo "raça negra". Não há no relatório uma explicação metodológica sobre a classificação de cor.

${ }^{169}$ A Antiga FEBEM (Fundação Estadual para o Bem estar do Menor) ganhou novo nome em janeiro de 2007 e, segundo o Governo do Estado de São Paulo, também um novo projeto pedagógico cujas linhas gerais prevêem a descentralização administrativa, a extinção de grandes unidades como o Complexo do Tatuapé e a construção de novas unidades, menores, nos municípios do interior paulista, procurando garantir que os internos estejam perto de suas famílias durante o cumprimento da medida de internação, como recomenda o ECA.

${ }^{170}$ Além da internação, na ocasião da pesquisa 116 jovens estavam em atendimento inicial, 1.353, internados provisoriamente, 524 cumprindo Semi-Liberdade, 12.972 em Liberdade Assistida (LA) e 2.916 cumprindo a medida de Prestação de Serviços à Comunidade (PSC).

${ }^{171}$ Fonte: Ilanud. Dado com base em novembro de 2006. A pouca relevância numérica das jovens internas produz, dentre muitas conseqüências, um interesse reduzido sobre as jovens infratoras. Não há informação disponível sobre seu perfil, tampouco sobre as condições nas quais estão cumprindo as medidas sócio-educativas. Assim como no sistema prisional, o fato de que não são um problema real para o Estado, quando comparadas ao universo de presos ou internos do sexo masculino, contribui para a invisibilidade de seus problemas.
} 
16 anos, 37\% 17 anos e 25\% 18 ou mais. De acordo com a auto-classificação sócio-econômica, 28\% declararam viver "numa casa de classe média", 31\% "numa casa de classe média baixa" e, 33\% "numa casa pobre" 172 .

No que diz respeito aos atos infracionais cometidos, quase $53 \%$ do total de internações resultaram de roubo qualificado; $14,4 \%$ dos jovens receberam a medida em função do tráfico de drogas, $8,7 \%$ foram culpados por homicídios, $1,2 \%$ porte de armas, e $22,9 \%$ representam a somatória de "outros crimes". Um dado relevante nesse cenário é que $29 \%$ do total da população internada é reincidente. Isso significa que quase um terço dos jovens cumprindo medida de internação já havia passado pelo sistema, cumprindo alguma medida sócio-educativa.

Quando perguntados sobre a presença de armas na sua casa, 22\% dos jovens responderam positivamente. Desse universo, $78 \%$ referiam-se a revólveres e em $80 \%$ dos casos as armas pertenciam ao próprio entrevistado, seguido de longe pelo irmão, (8\%) e pelo pai, em $3 \%$ dos casos.

No que se refere ao jovem, a não ser pelos dados relativos ao sexo e à idade, as duas pesquisas fazem perguntas diferentes sobre o universo de internados. Os dados do IPEA mostram um número alto de jovens negros, sendo que quase a metade desse universo avaliado não trabalhava nem estudava na época em que cometeu o crime. Chama a atenção nos dados da Fundação CASA os quase $60 \%$ de jovens que não se declararam como pobres, mas de classe média ou de classe média baixa. A informação contraria a percepção de pesquisadores e mesmo do senso comum de que são os jovens pobres os principais "clientes" do sistema de justiça juvenil ${ }^{173}$.

Em relação ao mundo da infração, as drogas parecem ter uma presença de destaque na vida dos entrevistados. As armas de fogo aparecem num número mais discreto, mas ainda assim significativo; sobretudo se levado em conta que em $80 \%$ dos casos o jovem era o proprietário da arma.

Ainda que haja uma distância temporal entre a realização das pesquisas, destacam-se as diferenças entre a distribuição dos atos infracionais. Enquanto os dados para o Brasil retratam um número grande de homicídios cometidos (quase 30\%), em São Paulo, esses crimes que tanto tem assustado a sociedade, os aparentes motores do debate sobre a redução da maioridade penal, respondem por apenas $8,7 \%$ dos jovens internados.

Hipóteses sobre esses crimes serão discutidas mais adiante, mas de imediato esses números levantam algumas questões. Em primeiro lugar, sugerem que a Justiça da Infância em São Paulo

\footnotetext{
${ }^{172}$ Essas são formas de classificação propostas pela própria pesquisa e não pelos entrevistados.

${ }^{173}$ Essa informação será discutida novamente num outro item desse mesmo capítulo.
} 
vem aplicando a medida de internação para crimes contra o patrimônio. Se isso parece inadequado se consideramos o que indica o ECA, a aplicação da medida está em perfeita sintonia com o imaginário a respeito da violência urbana e a necessidade de proteger a sociedade dos jovens. Mas, além disso, os números estabelecem uma espécie de dilema: os jovens fora de São Paulo cometem mais homicídios, ou a justiça não é capaz de chegar nos homicídios cometidos por esses jovens? Na medida em que estamos diante de jovens pobres matando outros jovens pobres, essa é uma hipótese que deve ser considerada e que, ao invés de criminalizar esse grupo, retrataria uma dupla vitimização dessa parcela da população.

De todo modo, o que os dados revelam até aqui é que o engajamento da "juventude pobre" da forma genaralizadora como é tratada, precisa ser posta em xeque, dado que, como veremos mais adiante nesse capítulo, há um universo muito maior de jovens vivendo nos centros urbanos, em contextos também de vulnerabilidade e que não estão envolvidos com a criminalidade.

Essa não é uma questão nova tampouco os dados nos permitem circunscrever esse universo com precisão. Mas eles subsidiam uma reflexão importante sobre os elementos, contextos e possivelmente os processos envolvidos no engajamento do jovem com a criminalidade ou os caminhos de uma sociabilidade que se constrói numa relação de proximidade com o crime.

\section{Causas e consequiências}

Lançada em 1999, a pesquisa 0 adolescente na criminalidade urbana em São Paulo ${ }^{174}$, buscava já num contexto de aumento das estatísticas criminais em São Paulo e de intensificação do debate acerca das causas associadas a esse aumento - dimensionar o envolvimento dos adolescentes nesse movimento, considerando na análise o período de 1993 a 1996, para comparar os resultados com uma pesquisa semelhante, realizada pela Fundação SEADE, utilizando os dados de 1988 a $1991^{175}$.

A investigação teve como ponto de partida três eixos de interesse: as ocorrências policiais praticadas por adolescentes na cidade de São Paulo, a identificação de um perfil social do adolescente autor de ato infracional e, por fim, um exame das medidas judiciais aplicadas, sendo

174 Adorno, Lima, Bordini, 1999.

${ }^{175} \mathrm{O}$ relatório final da pesquisa traz ainda uma síntese bastante completa sobre nichos explicativos na literatura que tratam do tema da adolescência e criminalidade, identificando quatro tendências: i Estudos que busca desconstruir o mito da periculosidade que estaria, naturalmente, associada à adolescência, ii. $\mathrm{O}$ acompanhamento sistemático da evolução da delinqüência praticada por esse grupo, iii. Estudos que abordam as causas do envolvimento dos jovens com o universo infracional e, iv. Abordagens que tratam das políticas públicas de controle social para essa parcela da população. 
esse último eixo, segundo os próprios autores, a "essência da investigação", que permitiu a compreensão “[...] do modo como o Estado tem operacionalizado suas diretrizes de controle repressivo da ordem social e ao mesmo tempo como tem procurado oferecer proteção, assistência e amparo à infância e à adolescência, em especial àqueles envolvidos com a criminalidade violenta ${ }^{176 "}$.

O resultado geral da pesquisa indica que há uma correspondência entre os padrões de envolvimento de jovens com a criminalidade e da população em geral - ou seja, estes não são nem mais nem menos violentos quando comparados ao total da população. 0 comportamento juvenil, ao longo dos anos estudados, apenas acompanhou o crescimento da criminalidade na cidade.

O que os autores observam, porém, é que as transformações nos tipos de crime praticados, sobretudo àquelas ligadas ao tráfico de drogas, promovem mudanças também no tipo de crime praticado pelos jovens. Essa seria uma explicação possível para o aumento mais proeminente nos crimes juvenis de natureza violenta.

Dimensionar com precisão a participação dos jovens naquilo que é classificado como "criminalidade urbana" é importante, ainda mais porque o movimento que cristaliza no imaginário social sua responsabilidade quase que exclusiva pela violência urbana é o mesmo responsável por ofuscar sua condição de vítima.

Mas, para além da sua conclusão geral, o "perfil social" desenhado pelo trabalho contribui com aquilo que estamos chamando de construção de uma "sociabilidade no crime". Partindo de variáveis como sexo, cor, idade, naturalidade, escolaridade e ocupação nos dois períodos destacados, e também comparando com o total da população, a pesquisa observa: i. Participação diferencial dos distintos grupos sociais na composição da delinqüência juvenil urbana; e ii. Clivagens econômicas e sociais expressam presença de adolescentes procedentes de distintas classes sociais no mundo do crime ${ }^{177}$.

Mostra ainda uma maior concentração do grupo de infratores no grupo etário de 16 a 17 anos e uma continuidade das características desse perfil entre os dois períodos. As diferenças apontadas se restringem à redução, no segundo período, do percentual de adolescente ativos no mercado de trabalho e ao aumento dos adolescentes estudantes.

O destaque do tópico, contudo, está na afirmação de que não é possível encontrar nas variáveis gênero, etnia, idade, escolaridade ou atividade ocupacional, qualquer indicativo de que elas

\footnotetext{
${ }^{176}$ Adorno, Lima, Bordini, op.cit: 63.

${ }^{177}$ Idem: 38.
} 
seriam determinantes de relevo na configuração de um suposto potencial para o envolvimento com a criminalidade.

Por parte da justiça ${ }^{178}$ e, como vimos, também por parte da formulação de políticas públicas, a leitura de que há um elo desse combinado de fatores e suas consequiências potenciais no que tange à delinqüência é mais evidente. Mas para análise do conjunto de informações que podem ser agrupadas sob o título de "causas da violência", a escolha de uma ou algumas variável como trilha explicativa se mostrou pouco interessante.

É antigo o interesse da Economia pela criminologia ou pela dimensão social das práticas criminais. Freakonomics $^{179}$, trabalho dos norte-americanos Steven Levitt, economista, e Stephen Dubner, jornalista, talvez tenha sido o estudo nesse caso que ganhou maior notoriedade nos tempos recentes. Dentre um conjunto de ensaios polêmicos sobre temas variados, os autores estabelecem uma ligação entre a legalização do aborto nos Estados Unidos durante os anos 70 e a queda da criminalidade no país nas duas décadas posteriores. A hipótese por trás do estudo é que crianças nascidas de uma gravidez indesejada têm maiores chances de se tornarem adolescentes conflituosos, com maior potencial de envolvimento com a criminalidade; isso quando comparadas a crianças nascidas de uma gravidez desejada. A legalização do aborto teria, portanto, evitado nos anos seguinte o nascimento de gerações de filhos indesejados, reduzindo assim, o número de adolescentes delinqüentes.

O livro se consagrou como um best-seller mundial e, ainda que hoje uma rápida consulta no Google possa indicar uma série de artigos que apontam erros metodológicos ou questionam a qualidade dos dados utilizados, colocando em suspeita a validade da hipótese ${ }^{180}$, o livro - mesmo para aqueles que não o leram - foi capaz de consolidar um certo senso comum sobre a relação entre a gravidez indesejada dos pobres e a criminalidade violenta.

O atual Governador do Rio de Janeiro, Sérgio Cabral, em declarações recentes e posteriormente contextualizadas, afirmou que as altas taxas de natalidade das favelas cariocas são, nas suas próprias palavras, “uma fábrica de produzir marginal”. Citando o livro de Levitt, o Governador defendeu que o aborto como política pública tem potencial para reduzir a violência ${ }^{181}$.

O que Sergio Cabral não considerou, entretanto, é que como mostram os números da última PNAD, as taxas de natalidade das regiões metropolitanas estão caindo. No Caso do Rio de Janeiro, a taxa era de 19,4 (para cada 1.000 habitantes) em 1993 e 14,9 em 2004 ${ }^{182}$. Ainda, não

\footnotetext{
178 Adorno, 1994; Miraglia, 2005.

${ }^{179} 2005$.

${ }^{180}$ Cf., por exemplo, Foote e Goetz (2005) uma das críticas pioneiras ao estudo.

${ }^{181}$ Folha de São Paulo, 25.10.2007.

${ }^{182}$ Fundação CIDE, 2006.
} 
há tanta diferença entre as taxas de natalidade de áreas ricas do Rio e as áreas pobres: o número médio de filhos de mães moradoras de favelas cariocas é de 2,6 enquanto no restante da cidade a média é de $1,7^{183}$.

$\mathrm{Na}$ época da declaração e da polêmica que a sucedeu, as taxas de natalidade do Brasil foram comparadas pela própria mídia que mostrou, com base nos dados do IBGE de 2000, que a taxa de fecundidade do Maranhão era de 3,2 filhos por mulher sendo essa uma região com indicadores baixíssimos de violência. Ao contrário do Rio de Janeiro que é uma cidade que apresenta uma taxa de fecundidade mais baixa - 2,1 -, mas lidera o ranking de mortes causadas por homicídios $^{184}$.

No Brasil, alguns estudos têm se debruçado sobre aspectos sociais específicos na tentativa de avaliar seu impacto sobre a criminalidade violenta, às vezes com inspiração bastante parecida ao livro mencionado acima. Esse é o caso da pesquisa desenvolvida pelo economista Gabriel Hartung, da FGV do Rio, cujo trabalho sugere que o controle de natalidade é um instrumento fundamental no combate à criminalidade no Brasil. Utilizando dados de São Paulo, o economista contrapõe fatores como proporção de filhos nascidos de mães adolescentes, nascidos de famílias monoparentais e a taxa de fecundidade a crescimento econômico, desigualdade e presença da polícia, para afirmar que o primeiro conjunto de fatores traria determinantes relevantes da criminalidade vinte anos depois ${ }^{185}$. No entanto, a despeito da pretendida objetividade dos modelos econômicos, tais estudos têm se mostrado insuficientemente conclusivos, sem conseguir provar uma relação causal entre as variáveis selecionadas. No caso do estudo de Hartung, alguns dos questionamentos tratavam da dificuldade em definir o que seria uma gravidez indesejada, na medida em que não é possível assumir que a taxa de natalidade entre jovens e adolescentes pode ser considerada imediatamente indesejada. Além disso, foi apontada também a intensa migração intermunicipal durante o período estudado o que impediria afirmar que os nascidos de mães jovens no município pesquisado seriam os criminosos nesse mesmo município ${ }^{186}$.

Posteriormente, num artigo no Jornal Folha de São Paulo, o economista reafirmou seu argumento, deixando claro que nãos se tratava de uma defesa da legalização do aborto ${ }^{187}$.

\footnotetext{
${ }^{183}$ Martine, Corrêa, 2007.

${ }^{184}$ Idem.

185 A pesquisa foi lançada com ampla divulgação para a mídia em meados de setembro 2007, ressuscitando o debate sobre o tema. Autor e seu orientador anunciaram que o trabalho estava "em fase de conclusão". Além da polêmica na imprensa, a divulgação parcial dos dados provocou um intenso debate entre a comunidade acadêmica. Entretanto, a versão integral do estudo não está disponível.

${ }^{186} \mathrm{O}$ estudo, assim como o tema, foi intensamente debatido na lista de discussões "População e Pobreza", criada pela diretoria da Associação Brasileira de Estudos Populacionais (ABEP). O conteúdo integral das discussões e das críticas pode ser acessado na página: $<$ http://br.groups.yahoo.com/group/PopPobrezaABEP $>$.

${ }^{187}$ Folha de São Paulo, 27.10.2007.
} 
Ainda que a forte associação entre variáveis não seja suficiente para estabelecer uma relação de causalidade entre elas, seria igualmente equivocado afirmar que não há nenhuma relação de causalidade entre famílias numerosas, contextos de privação, ausência de um dos pais, e todos os outros elementos evocados pelo cenário descrito por Cabral com as taxas de criminalidade. Essas são, claro, dimensões importantes do problema. Mas selecionar apenas uma dentre todas não tem se mostrado um caminho possível ou mesmo frutífero para a compreensão do problema.

O alarde causado cada vez que uma investigação dessa natureza é anunciada, ou o conforto do Governador para fazer declarações públicas nesse sentido, precisam ser considerados. Por um lado deixam claro que hipóteses como essa reverberam num imaginário coletivo acerca das relações existentes entre pobreza e criminalidade. Por outro, do ponto de vista técnico, apenas reforçam as dificuldades tradicionalmente encontradas para peneirar as causas da violência.

Na série de "Textos para Discussão" produzidos pelo IPEA (Instituo de Pesquisas Aplicadas), há uma pesquisa recente que elege o tema da educação para analisar os números da violência no Brasil. O autor vê na educação formal um "escudo conta o homicídio ${ }^{188 ” . ~ P a r t i n d o ~ d a ~ a l e g a d a ~}$ ausência de estudos que explorem, de uma perspectiva quantitativa, a relação entre crime violento e educação, o estudo propõe uma análise das relações entre nível de instrução formal e as chances de ser vítima de homicídio. Para tanto a pesquisa faz uso das informações do SIM (Sistema de Informações sobre Mortalidade) do Ministério da Saúde e da PNAD, comparando as taxas de homicídio por idade para níveis distintos de instrução formal. 0 período considerado é de 1999 a 2004.

As primeiras conclusões do estudo reforçam uma conclusão que já é consenso a respeito do tema: as vítimas são majoritariamente do sexo masculino; negros têm mais chance de serem vitmizados por homicídios do que brancos; e os "jovens" (nesse caso entre 16 e 36 anos!) formam o grupo de risco.

O autor faz coro com as interpretações correntes e enfatiza o aspecto relacional das situações que podem resultar num homicídio:

"Imaginamos aqui que qualquer descrição adequada do processo que leva a um homicídio envolve várias relações. Uma descrição simples inclui no mínimo duas: o grau de vulnerabilidade da vítima e a propensão de ela estar em situações ou ambientes nos quais o conflito letal é provável. Uma viúva idosa, por exemplo, dificilmente estará em ambientes ou situações de possível conflito letal, mas é altamente vulnerável, o que possivelmente explica o aumento na taxa de morte por homicídio de mulheres com idades acima de 50 anos, visível no gráfico 3 adiante (subseção 4.1, p. 20). Já um jovem de sexo masculino talvez não seja tão vulnerável, mas está com freqüência em situações de risco, que podem variar de brigas de bar até o engajamento em uma carreira criminal,

${ }^{188}$ Dillon Soares, 2007. 
onde o conflito é possível. O relevante é que uma descrição adequada do processo de vitimização por homicídio envolve duas ou mais equações diferentes." ${ }^{\prime 189}$

Em primeiro lugar é importante notar que a noção de vulnerabilidade ganha outro significado que não o de "vulnerabilidade social", utilizada nos capítulos anteriores. Aqui ela assume um sentido mais genérico, mais próximo do seu significado etimológico, segundo o qual um jovem teria mais condições de se proteger do que uma viúva idosa.

Mas nas situações descritas na citação acima são somados a essa vulnerabilidade - que compreende na leitura do economista idade, sexo e estado civil - outros determinantes, tais como os hábitos e o próprio ambiente.

O avanço agregado pela pesquisa seria a possibilidade de afirmar que a escolaridade é capaz de reduzir o risco de morte por homicídio. Acompanhando o número de jovens mortos e as taxas de escolaridade, o autor conclui que jovens com 1 a 3 anos de escolaridade têm mais chance de morrer vítimas de homicídios do que aqueles que terminaram pelo menos o primeiro ciclo do fundamental. Apresentam chances ainda maiores quando comparados aos que têm entre o $\begin{array}{llllll}\text { fundamental completo } & \mathrm{e} & \mathrm{O} & \text { médio } & \text { completo. }\end{array}$

As evidências numéricas encontradas são explicadas por meio dos seguintes argumentos:

"[...] mesmo que uma criança de baixo status socioeconômico freqüentando uma escola com professores mal pagos e mal formados não esteja aprendendo português ou matemática a contento, ela está aprendendo um modo de socialização que eventualmente poderá salvar-lhe a vida. E mais: é possível que, ao ensinar esta criança a como lidar com o conflito de modo não letal, a escola esteja também salvando a vida de terceiros. A conclusão inexorável é que a política educacional deve fazer tudo ao seu alcance para manter a criança na escola, mesmo que a aprendizagem de conteúdos acadêmicos seja aquém do desejado. Nesse sentido, políticas de progressão continuada devem ser incentivadas ao máximo, uma vez que há uma relação conhecida entre ser reprovado e evadir do processo educacional. Não se trata apenas de aprender a ler e escrever: é questão de vida e morte." ${ }^{190}$

O autor, no entanto, parece não conhecer a extensa produção recente sobre violência escolar ${ }^{191}$ que retrata um ambiente - sobretudo nas áreas de maior vulnerabilidade social coincidentemente aquelas com altas taxas de homicídios - marcado por relações de violência entre alunos e professores, professores e alunos, pais e professores e, em muitos casos, com a presença ostensiva do tráfico de drogas. As agressões físicas, verbais e psicológicas, incluem ainda altas

\footnotetext{
${ }^{189}$ Idem: 12.

${ }^{190}$ Ibidem: 29.

${ }^{191}$ Abramoway, Rua, 2002; Abramoway, Castro, 2006b; Tavares dos Santos, 2002.
} 
doses de preconceito. Esse último, de acordo com a pesquisa realizada em cinco capitais brasileiras - Belém, Salvador, São Paulo, Porto Alegre e Brasília - entre os anos de 2003 e 2005, manifesto de diversas maneiras, desde o tratamento dispensado pelos professores que é diferente para alunos negros e brancos, o desempenho escolar desigual entre alunos brancos e negros, até os inúmeros apelidos associados à cor de pele ou tipo de cabalo, comuns no ambiente escolar $^{192}$.

Nesse sentido, as conclusões do estudo parecem dialogar muito mais com o apoio ou não a uma determinada política de educação do que com seu real impacto nos índices de violência. A relação de causalidade entre os dois fenômenos é cercada de cautela pelo próprio autor e a conclusão da pesquisa não deixa claro se a renda não seria ainda mais determinante do que a escolaridade.

Um exercício rápido, considerando a geografia dos crimes em São Paulo, por exemplo, já sugere intuitivamente uma ponderação sobre os riscos de um indivíduo que concluiu apenas o ensino médio, mas é morador de Alto de Pinheiros, e um universitário, como é o caso de Marcelo, morador do Jardim Ângela.

Não há dúvida de que além de uma relação objetiva entre causa e conseqüência, há uma dimensão política e até mesmo ideológica em torno das causas da violência, mas o caráter inconclusivo do estudo e a sobreposições de variáveis para sustentar a hipótese são úteis na medida em que explicitam a dificuldade em isolar, mesmo por meio de modelos matemáticos, uma única variável para explicar a redução ou o aumento de um determinado tipo de violência.

A afirmação da violência como um fenômeno multicausal, mais do que uma reivindicação já desgastada ou vaga, é um ponto de partida essencial.

\section{Um cotidiano de violência}

A dificuldade em isolar um ou outro elemento e classificá-lo como determinante, numa relação imediata de causa e efeito, não impede a análise de trajetórias ou processos onde uma sociabilidade é construída num diálogo constante, em muitos níveis - individual, comunitário e estrutural - com a ilegalidade.

Afinal, como bem aponta Luiz Eduardo Soares, "a carreira no crime é uma parceria entre a disposição de alguém para transgredir as normas da sociedade e a disposição da sociedade para

${ }^{192}$ Abramoway, Castro, 2006b. 
não permitir que essa pessoa desista”193. Ainda que não seja possível atribuir com precisão o peso que "a sociedade" e o indivíduo têm nessa equação, os termos em quem essa parceria é conjugada podem dar pistas interessantes sobre essa sociabilidade em construção.

Os dados apresentados a seguir fazem parte de uma pesquisa realizada em 2007, pelo llanud em quatro municípios de São Paulo, incluindo cinco programas de execução de medidas sócioeducativas em meio aberto - Liberdade Assistida e Prestação de Serviços a Comunidade.

A pesquisa em tais programas é parte de um projeto mais amplo, realizado em parceria com a Fundação Telefônica, que os apoiou durante 2006 e 2007, por meio do Fundo dos Direitos da Criança e do Adolescente. No total foram entrevistados 481 jovens em cumprimento de medida. 0 objetivo primordial da pesquisa era conhecer o adolescente e não avaliar os programas ${ }^{194}$.

A “Prestação de Serviços à Comunidade" (PSC) está prevista no artigo Art. 117 do ECA, segundo o qual a medida consiste “[...] na realização de tarefas gratuitas de interesse geral, por período não excedente a seis meses, junto a entidades assistenciais, hospitais, escolas e outros estabelecimentos congêneres, bem como em programas comunitários ou governamentais".

Há uma limitação prevista na própria lei que determina uma jornada máxima de trabalho de 8 horas semanais para o adolescente. A medida deve ser cumprida preferencialmente aos sábados, domingos ou feriados, para não prejudicar a suposta rotina escolar ou a jornada normal de trabalho do jovem.

Em tese, a atribuição das tarefas, ou seja, a caracterização dos serviços a serem prestados como estratégia de socioeducação, deveria ecoar minimamente as aptidões do adolescente, seu lugar de residência, e até mesmo o ato infracional cometido. Cabe ao juiz essa averiguação e indicação.

Mas na prática, na maioria dos casos, a PSC é cumprida em outros termos. Em primeiro lugar, dá margem a altas doses de discricionariedade por parte do juiz. Esse poderia ser um dado positivo, uma vez que permitiria, como prevê o ECA, a modelagem da medida à luz das necessidades de cada jovem. Mas como é considerada uma "medida leve", tem a sua dimensão punitiva exacerbada para que a didática da repreensão fique clara e não reste dúvida, para o jovem, de que ele está sendo acima de tudo punido pela infração cometida. Com efeito, a prestação de serviços, ou essa "lição", é traduzida, na maioria dos casos, na realização de tarefas braçais

\footnotetext{
${ }^{193}$ Soares, 2005: 218 in Soares, Bill, Athayde, 2005.

${ }^{194} \mathrm{~A}$ coordenação da pesquisa ficou a cargo de Karyna Sposato. Os programas contemplados ficavam nas cidades de Guarujá, Campinas e Jandira. O conteúdo integral da pesquisa, que compreende não apenas um perfil dos jovens, mas também sua percepção do programa, pode ser encontrada na publicação "Media Legal" (título provisório).
} 
como pintar muros ou limpar banheiros. Em muitas ocasiões, o jovem inclusive cumpre a medida na própria escola que freqüenta na condição de estudante. Não é preciso um grande esforço para observar o privilégio da punição em detrimento do caráter pedagógico da medida ${ }^{195}$.

A Liberdade Assistida é um meio do caminho entre uma medida leve e a internação. A privação da liberdade é o grande termômetro (além, é claro, de objeto de disputa entre juízes, promotores e defensores) indicativo seja da gravidade do ato, seja da leitura que o juiz faz do potencial de recuperação do jovem. Dado que o próprio ECA determina que deve haver uma correspondência entre a gravidade do ato infracional cometido e a medida aplicada, o princípio que fundamenta a aplicação de uma LA é que o jovem não cometeu um ato infracional tão grave que the valha uma internação, mas que sua liberdade deve ser assistida, auxiliada.

Seu qualificativo "assistida" explicita que o jovem não tem condições, naquele momento, de administrar a sua própria liberdade e que, portanto, deve ser "acompanhado" até que possa exercer sua autonomia plena, novamente.

Entre os atores envolvidos com o cumprimento de medidas (juízes, promotores e defensores, psicólogos, técnicos, entre outros) a LA é percebida como a medida com maior potencial sócioeducativo, uma vez que o acompanhamento do jovem associado ao cumprimento em meio aberto permitiria ao adolescente, idealmente, freqüentar a escola regularmente, conviver com a sua família e comunidade, sem romper laços sociais como faz a internação.

Mas assim como a PSC, o cumprimento é variado e os Programas que recebem os adolescentes são irregulares no que diz respeito à sua estrutura, ao tipo de atendimento que oferecem (cursos e capacitações) e mesmo em relação à qualificação dos técnicos que fazem o acompanhamento ${ }^{196}$.

A série de gráficos a seguir apresenta parte dos resultados da pesquisa.

\footnotetext{
${ }^{195}$ Está em fase de conclusão no Ilanud o Mapeamento Nacional das Medidas sócio-educativas em Meio Aberto pesquisa desenvolvida em parceria com a Subsecretaria de Promoção dos Direitos da Criança e Adolescente, da Secretaria Especial de Direitos Humanos da Presidência da República. Os resultados preliminares mostram um panorama nacional bastante variado no que se refere à atuação do judiciário $\mathrm{e}$ as modalidades de cumprimento das medidas em meio aberto.

${ }^{196}$ Aqui vale registrar a desproporcionalidade das responsabilidades que o ECA prevê para os técnicos. De acordo com o artigo 119, "Incumbe ao orientador, com o apoio e a supervisão da autoridade competente, a realização dos seguintes encargos, entre outros: I - promover socialmente o adolescente e sua família, fornecendo-lhes orientação e inserindo-os, se necessário, em programa oficial ou comunitário de auxílio e assistência social; II - Supervisionar a freqüência e o aproveitamento escolar do adolescente, promovendo, inclusive, sua matrícula; III - Diligenciar no sentido da profissionalização do adolescente e de sua inserção no mercado trabalho; IV- Apresentar relatório do caso". Em outras palavras, cabe ao orientador proporcionar, geralmente nos seis meses em que a medida é aplicada, toda a vida que o adolescente não teve até então. Vale ainda notar que atualmente em São Paulo está em curso o processo de municipalização das medidas em meio aberto o que, idealmente, deve transformar positivamente esse panorama.
} 
Gráfico 1

Entrevistados segundo sexo

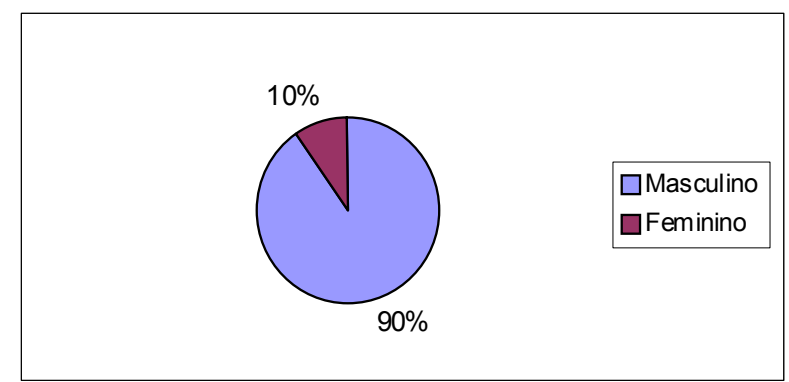

Gráfico 2

Entrevistados segundo idade

Em relação à sua cor você se declara
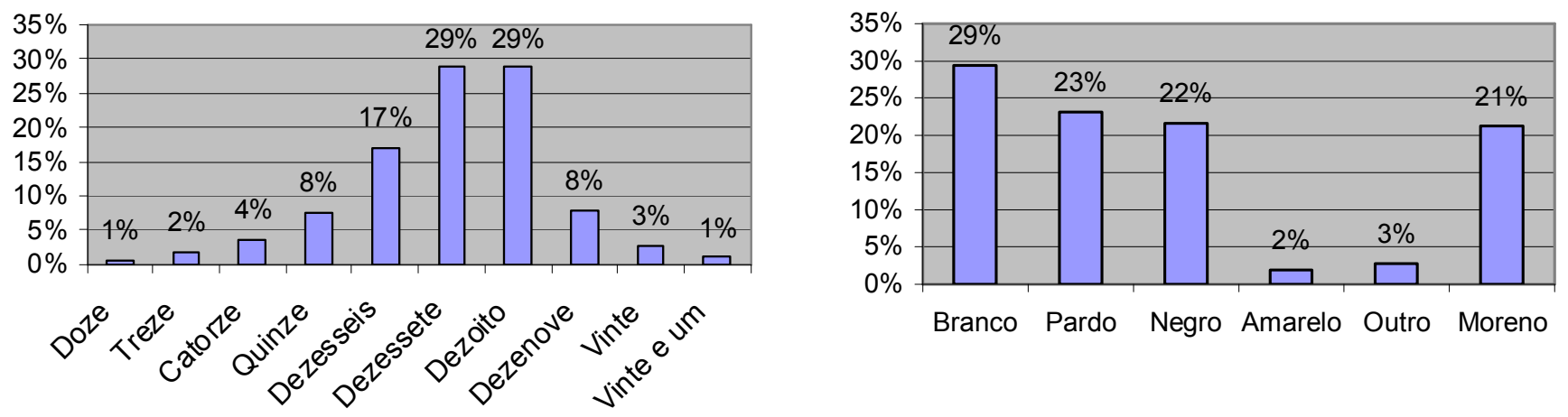

Os gráficos 1, 2 e 3 descrevem um universo similar àquele dos jovens cumprindo medida de internação, ou ao universo de jovens infratores - objeto da pesquisa de Adorno ${ }^{197}$ - , assim como àquele que já no início do trabalho havíamos descrito como as vítimas primordiais da criminalidade violenta: é predominantemente masculino, formado por jovens com idades concentradas entre 16 e 18 anos. Há ainda uma concentração de jovens que se declaram nãobrancos (pardos, negros ou morenos totalizam 66\% das respostas).

Aqui vale notar que diante do número tradicionalmente inexpressivo de jovens do sexo feminino cumprindo medidas sócio-educativas, os $10 \%$ (pouco mais de 48 jovens) encontrados pela pesquisa ganham importância.

${ }^{197}$ Adorno, Lima, Bordini, 1999. 
Gráfico 4

Mora ou morou em abrigo

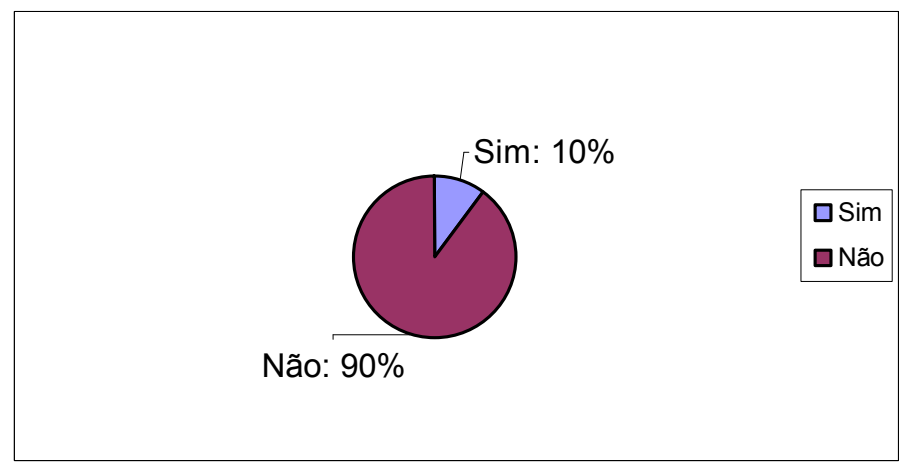

\section{Gráfico 5}

Quantas pessoas habitam a mesma casa?

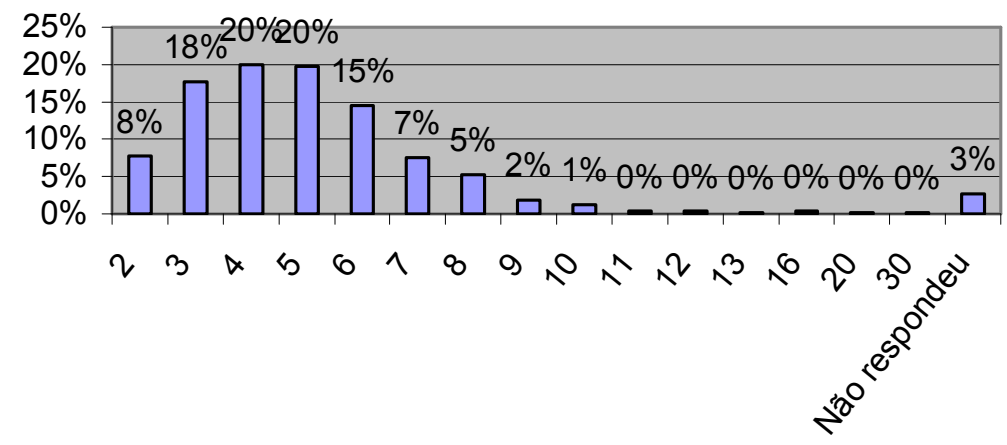

\section{Gráfico 6}

Quem mora com você?

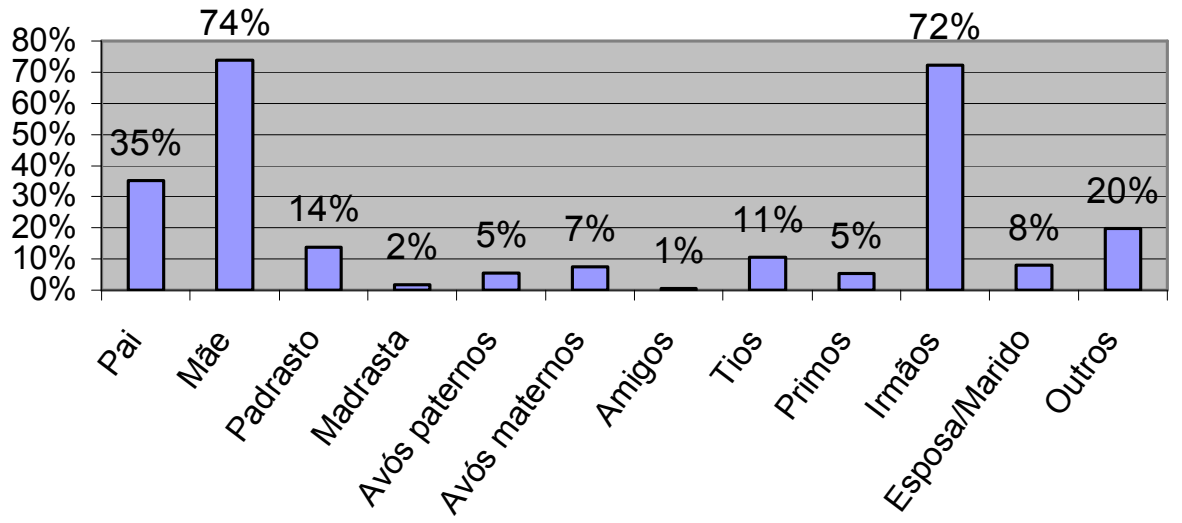

O conjunto formado pelos gráficos 4,5 e 6 diz respeito aos padrões de moradia dos jovens. A maioria significativa dos entrevistados nunca morou em abrigo e habita atualmente nas respectivas casas, com a família. Não é possível, a partir desses dados, inferir o número de jovens que mora 
exclusivamente com as mães (sem o pai), mas o número de jovens morando com a mãe (74\%) elou com os irmãos (72\%) é mais do que o dobro das respostas que apontaram os pais (35\%). Esses dados dialogam com os recentes indicadores sociais do IBGE que apontam um aumento de $76 \%$ no número de mulheres chefes de família.

Sobre famílias com laços de parentesco residentes em domicílios particulares, os números que tratam da relação entre o sexo da pessoa de referência da família e a presença de cônjuge são bastante significativos: quando o homem é a pessoa de referência em 94,4\% dos casos ele vive com o cônjuge. Quando as mulheres são as pessoas responsáveis esse número cai para 20,7 \% ${ }^{198}$.

A média da renda familiar mensal declarada dos entrevistados concentra-se na faixa de 01 a 03 salários mínimos. Em outras palavras, seja do ponto de vista da renda, seja da perspectiva dos arranjos familiares, estamos falando de um contexto de baixa renda.

\section{Gráfico 7}

Onde presenciou cenas de violência?

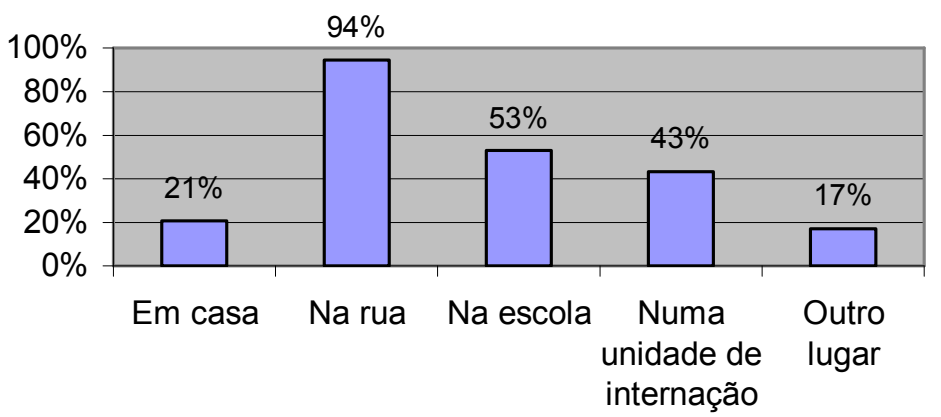

\section{Gráfico 8}

Que tipo de violência presenciou?

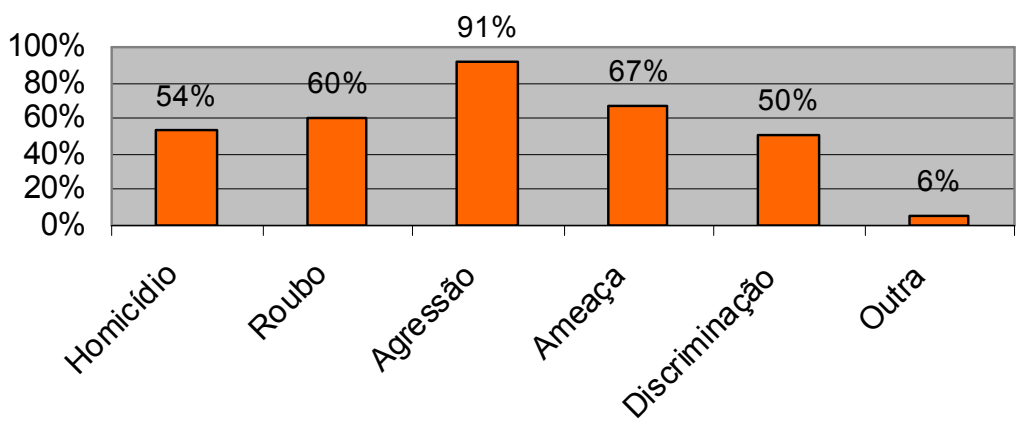

\footnotetext{
${ }^{198}$ IBGE, 2004. Mesmo não sendo objeto desse estudo, vale notar que os indicadores mostram, ainda, as estratégias de reprodução das famílias monoparentais, particularmente as femininas.
} 


\section{Gráfico 9}

Onde sofreu a violência?

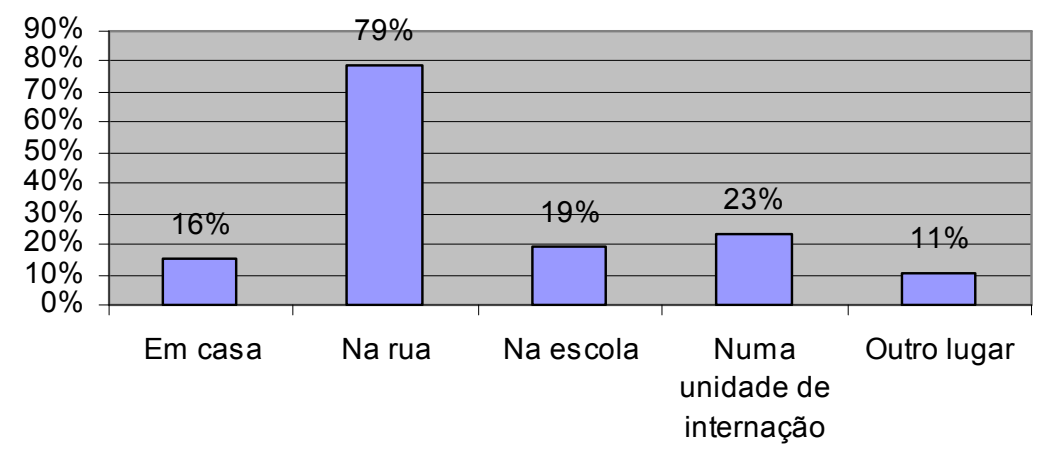

\section{Gráfico 10}

Que tipo de violência sofreu?

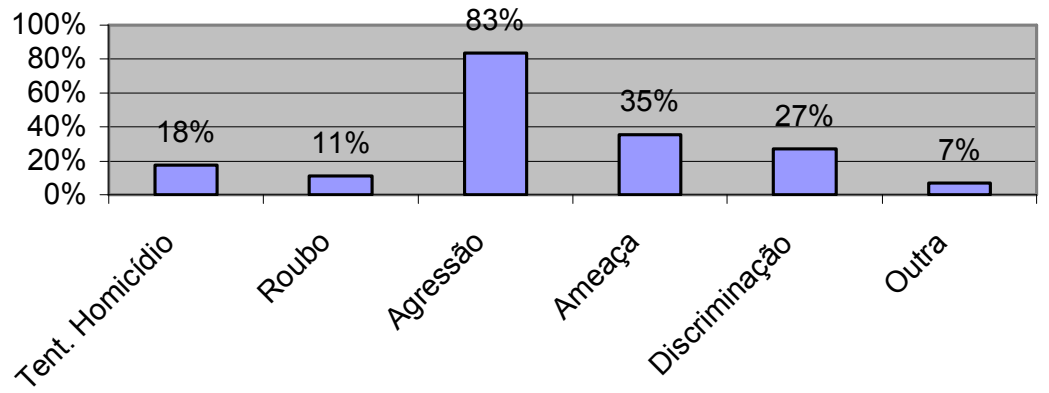

A série formada pelos gráficos 7, 8, 9 e 10 traz as primeiras informações sobre o adolescente e sua relação com a violência e o universo infracional. Aqui é preciso registrar que os entrevistados puderam escolher mais de uma alternativa e por isso a somatória das respostas ultrapassa os $100 \%$.

Partindo da informação de que a totalidade dos entrevistados afirma ter presenciado ou vivido situações de violência, os dados nos dão mais detalhes sobre os contextos e o tipo de violência presenciada ou sofrida.

A rua, local mais citado em ambos os casos, se apresenta como o grande palco para práticas dessa natureza. Ainda assim, a escola e a própria casa são também contextos relevantes. A escola se destaca, sendo citada em $56 \%$ das repostas relativas à violência presenciadas. Os dados dão pistas sobre um circuito que caracteriza os espaços de convivência de jovens nessa faixa-etária, casa rua - escola - permeado por modalidades variadas de violência. Soma-se a isso a violência praticada no interior das unidades de internação. Como veremos mais adiante, boa parte dos entrevistados já esteve internado como resultado de um ato infracional cometido anteriormente. 
Chama a atenção o número extremamente alto $(54 \%)$ de jovens que presenciaram pelo menos um homicídio na sua vida.

Os dados não permitem uma análise precisa sobre o tipo de crime praticado contra essa população, mas sugerem que os crimes patrimoniais têm uma importância secundária e que adolescentes nesse universo estão mais sujeitos à serem vitimizados pela violência interpessoal.

De todo modo, é possível dizer que a violência, nas suas diversas modalidades, integra o cotidiano desses jovens. Não é um fenômeno que lhes é estranho, mas ao contrário, parece ser demasiadamente familiar.

\section{Gráfico 11}

Já utilizou algum tipo de droga legal ou ilegal

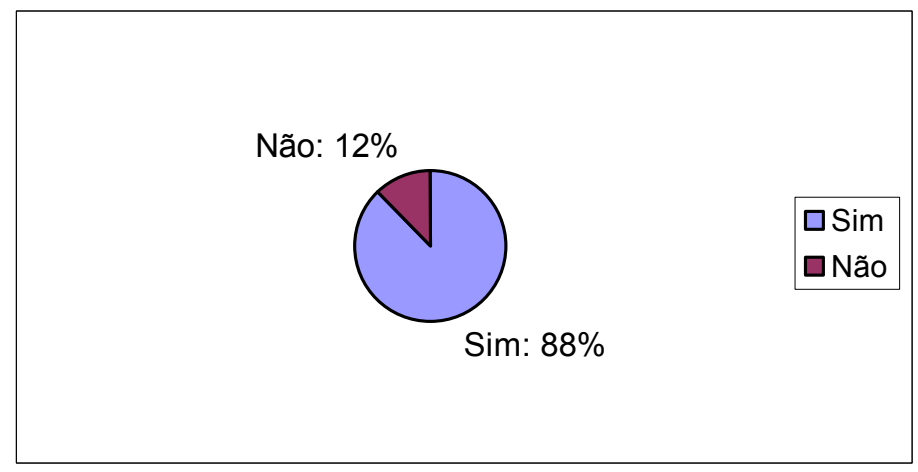


Gráfico12

Quais drogas já utilizou?

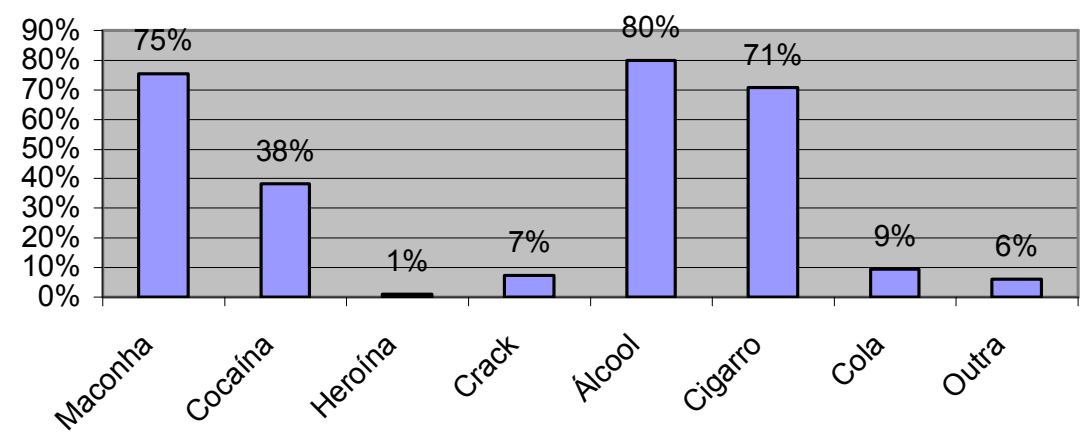

\section{Gráfico 13}

Você utiliza atualmente algum tipo de droga legal ou ilegal

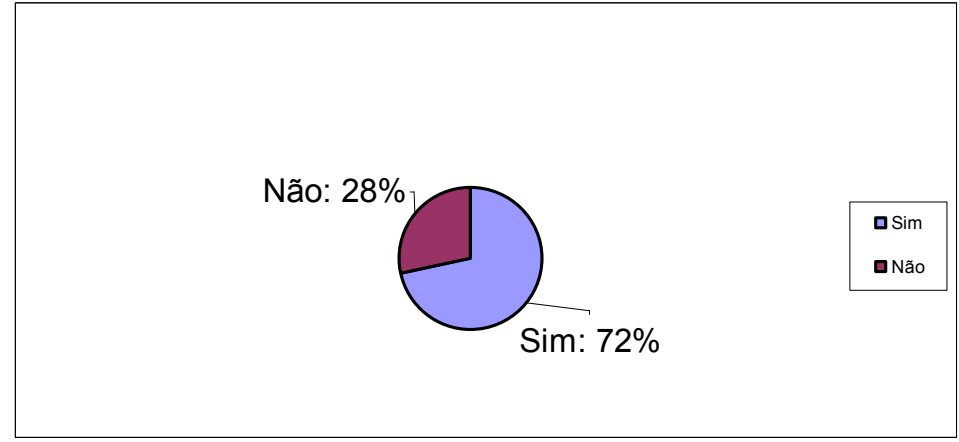

\section{Gráfico 14}

Quais drogas utiliza atualmente?

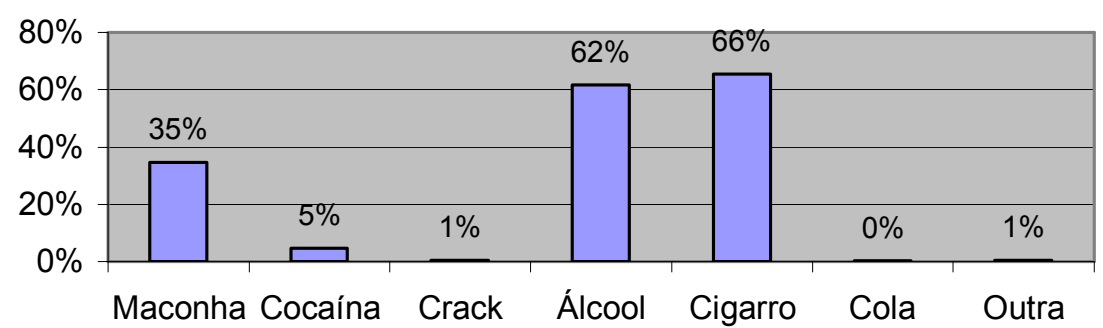




\section{Gráfico 15}

Alguém da sua família utiliza algum tipo de droga legal ou ilegal?

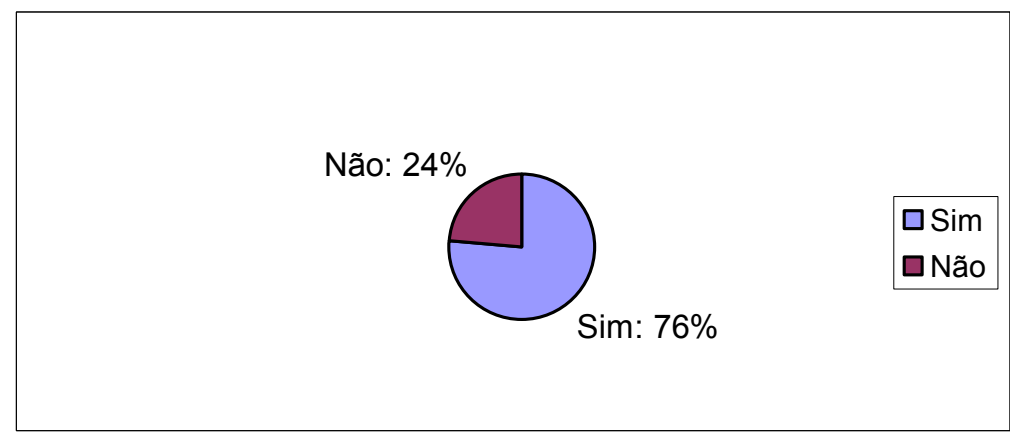

Gráfico 16

Qual tipo de droga seu parente utiliza?

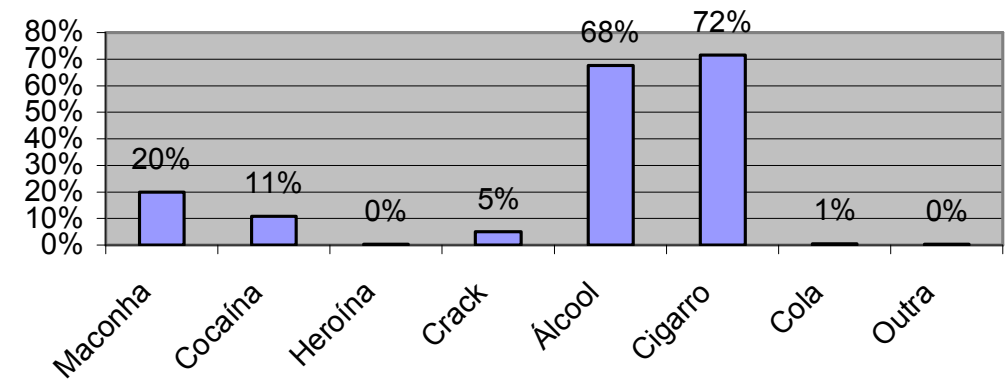

As informações contidas nos gráficos 11 a 16 dizem respeito ao consumo de drogas dos entrevistados e seus parentes. Nesse caso, novamente mais de uma alternativa podia ser assinalada como reposta.

Quase $90 \%$ dos jovens afirmam ter feito uso de drogas legais ou ilegais. A associação entre as drogas licitas e ilícitas nas perguntas impede a separação das respostas, mas vale lembrar que os entrevistados têm todos menos de 18 anos e que, portanto, de acordo com a lei, o consumo de álcool e mesmo de cigarro nesse caso é ilegal. Além do mais, acima de 70\% dos entrevistados ainda usa drogas. O álcool e o cigarro concentram o maior número de usuários, mas há um número elevado de entrevistados que faz uso de maconha e da cocaína. O destaque fica por conta da redução no uso desse tipo de droga. Os dados não nos permitem saber se, de alguma maneira, tal fato está relacionado com o cumprimento da medida.

Os gráficos mostram, todavia, que as drogas não estão restritas à vida dos jovens entrevistados, mas também fazem parte do cotidiano de outros membros da sua família. No caso da família, o uso também é concentrado no álcool e no cigarro, drogas lícitas. Mas é relevante que em um 
quinto dos casos algum familiar faz uso de maconha e em pouco mais de $10 \%$ dos casos algum membro da família utiliza cocaína.

\section{Gráfico 17}

Você já teve uma arma de fogo nas mãos?

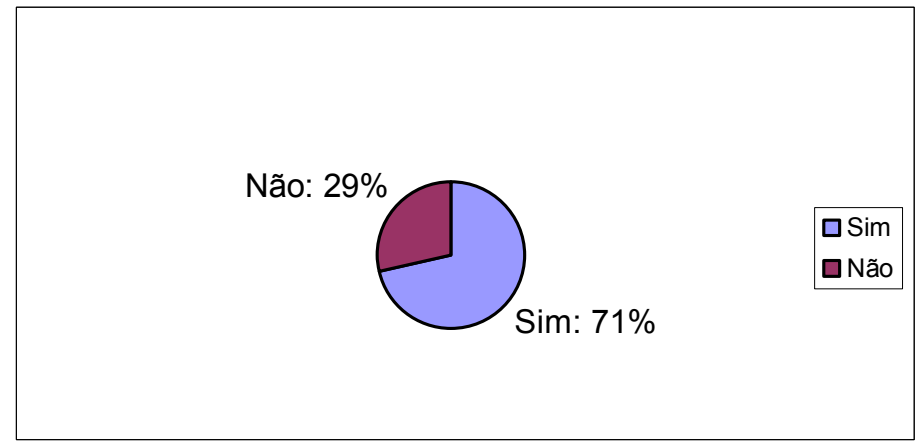

Gráfico 18

Caso você quisesse obter uma arma de fogo isso seria

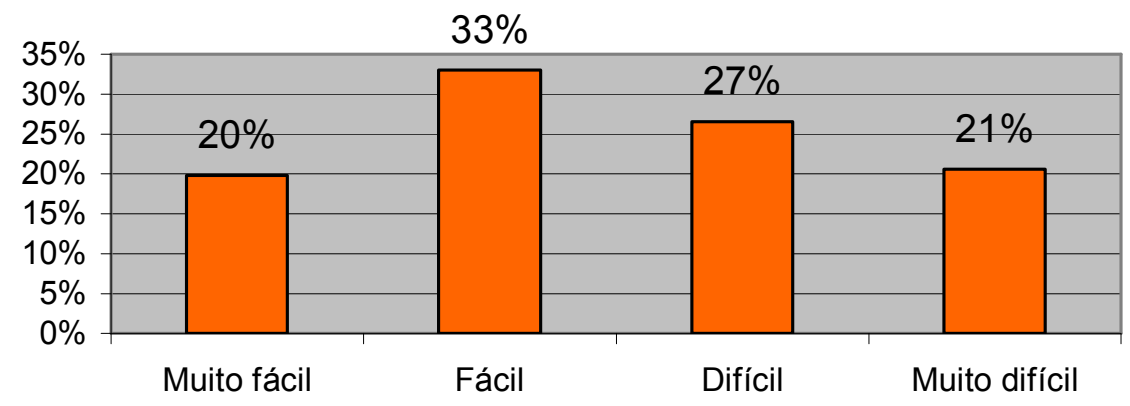

Os dados apresentados nos gráficos 17 e 18 ilustram as afirmações relativas à disseminação das armas de fogo no mercado ilegal e seu papel capital na perpetração da violência, tema tratado no capítulo 1.

A declaração de mais de $50 \%$ dos entrevistados atestando que seria "fácil" ou "muito fácil" obter uma arma, somado aos mais de $70 \%$ que afirmaram já terem tido uma arma em mãos, indica o quanto esse é um elemento quase que trivial nas suas vidas. 


\section{Gráfico 19}

Alguém da sua família já cometeu algum crime e foi condenado por isso?

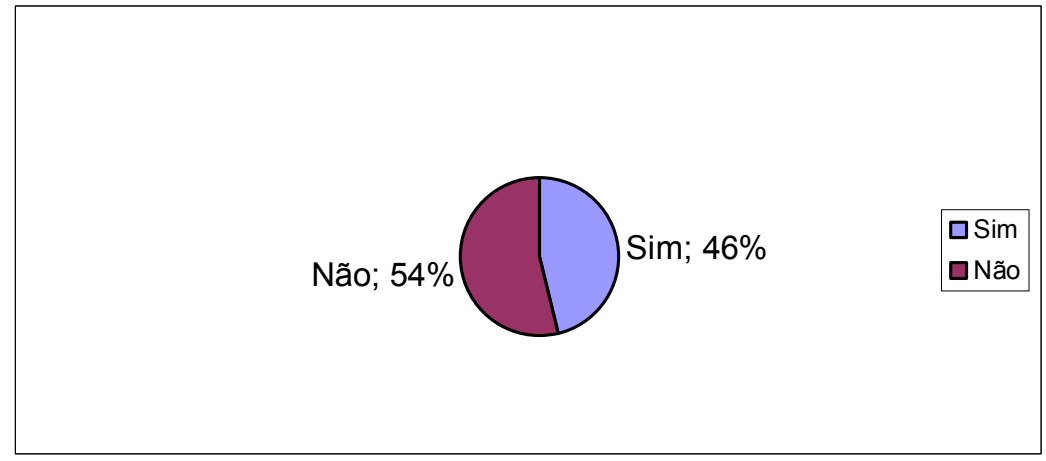

\section{Gráfico 20}

Qual o grau de parentesco?

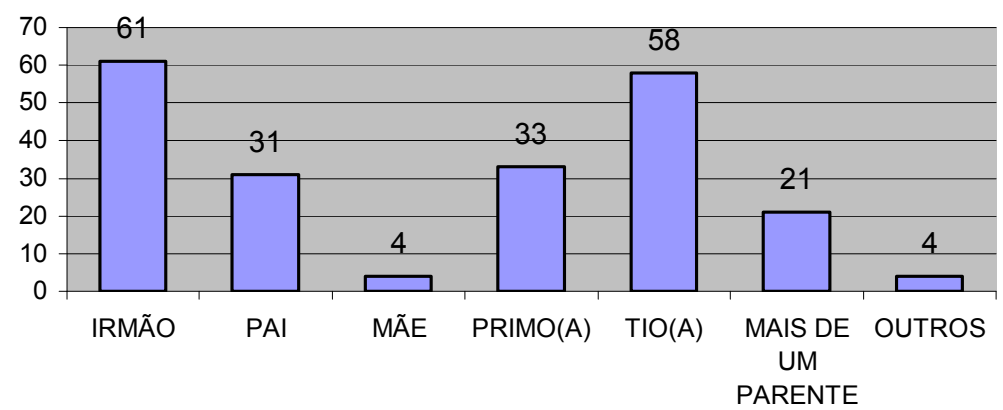

Gráfico 21

Qual foi o crime cometido?

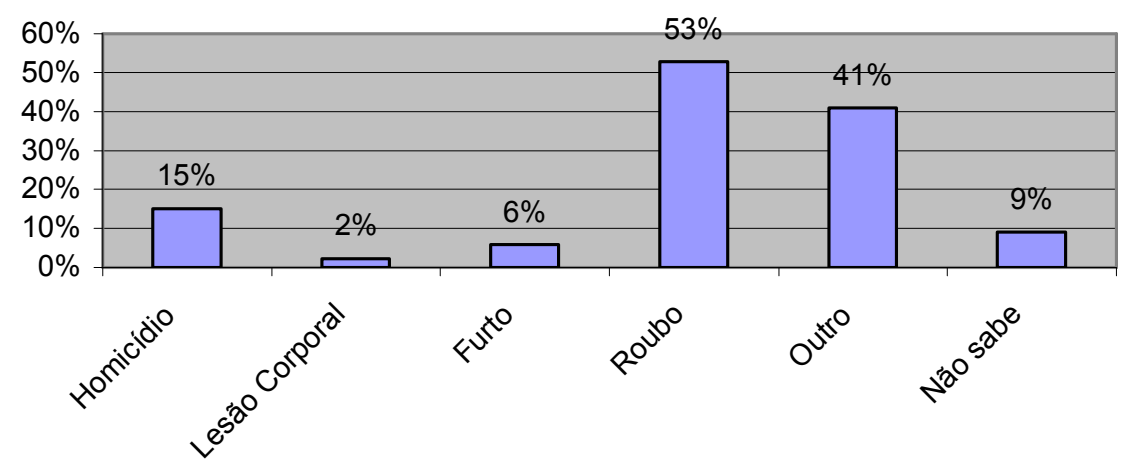


Gráfico 22

Qual o tipo de pena recebida?

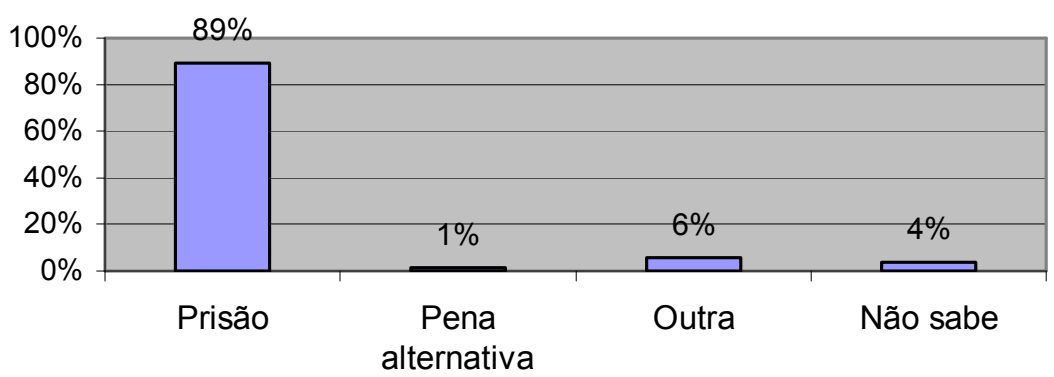

Os gráficos 19 a 22 mostram a familiaridade dos jovens, por meio de suas relações de parentesco, com a justiça criminal e o sistema prisional. Quase metade dos entrevistados (46\%) já teve um parente que cometeu um crime e foi condenado pelo sistema.

O gráfico 20 traz a distribuição das repostas positivas distribuídas em números absolutos. 21 dentre os 481 entrevistados respondeu que mais de um parente viveu essa situação. Os irmãos e os tios são os familiares mais citados, seguidos pelos primos e os pais. 0 gênero como um filtro para a prática e interpretação desse tipo de violência fica evidenciado pelos dados: são os parentes do sexo masculino que já passaram ou estão no sistema. 0 fato de que são os parentes mais velhos os envolvidos nos permite pensar numa trajetória individual no crime amparada por um biografa familiar que também integra esse universo.

A alta incidência da pena privativa de liberdade sugere que foram crimes graves, além de retratar biografias familiares onde não apenas o crime, mas o sistema de justiça, assim como o sistema prisional, fazem parte da história dos mesmos.

Podemos assumir que em se tratando de relações familiares, estamos falando de pessoas que compartilham um contexto e estão inseridas em algumas redes semelhantes. Não se trata de assumir um determinismo social, mas de pensar numa sociabilidade que é construída a partir de premissas compartilhadas. Portanto, uma sociabilidade em que criminalidade e a inserção no sistema de justiça criminal são partes do cotidiano.

\section{Gráfico 23}

Você praticou algum ato infracional anterior ao que ensejou a atual medida? 


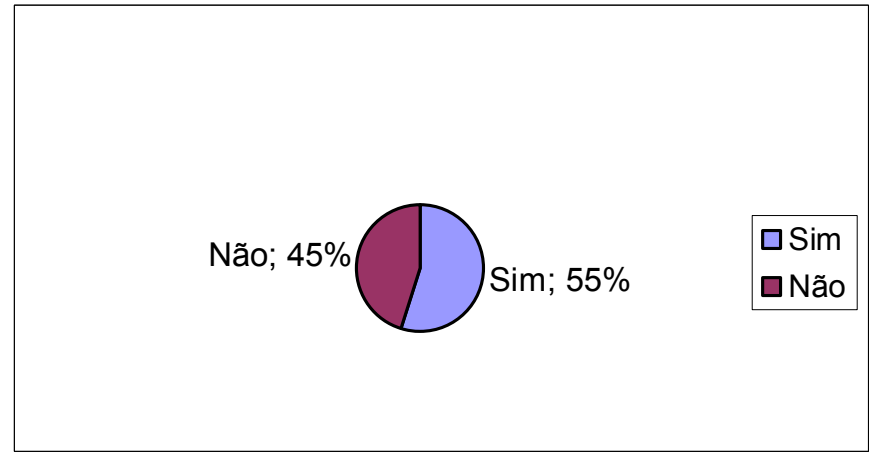


Gráfico 24

Qual foi o ato cometido

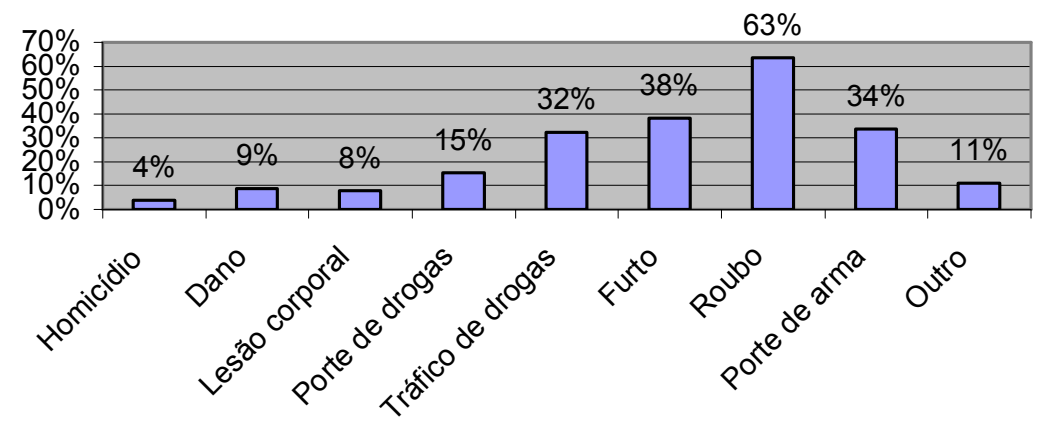

Gráfico 25

Quais medidas recebeu em razão do ato anterior ${ }^{199}$

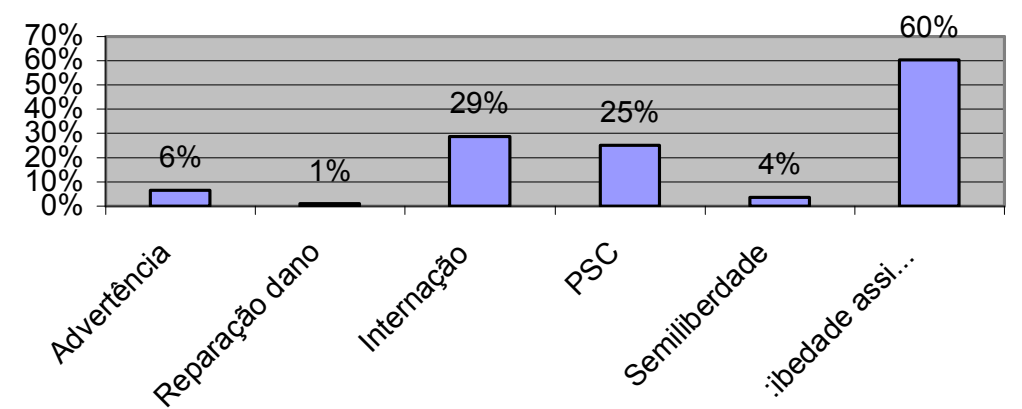

Gráfico 26

Quantos anos você tinha quando cometeu o ato anterior

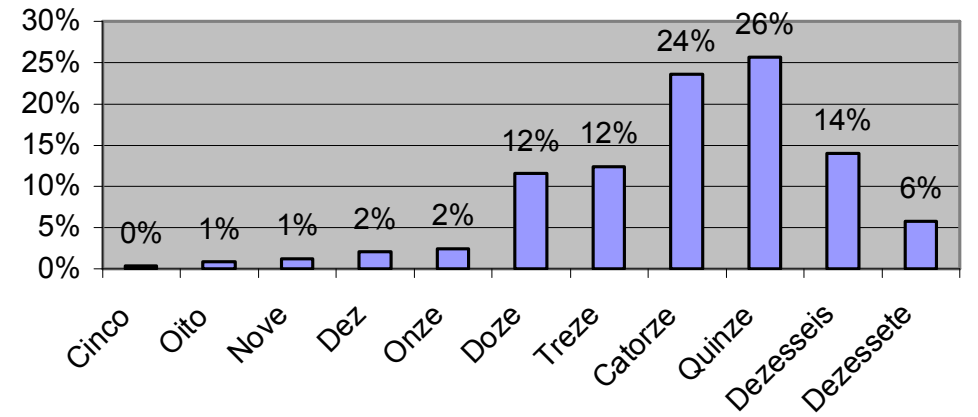

${ }^{199}$ A possibilidade de acumulação de medidas ou a progressão de uma medida para outra explicam a somatória maior do que $100 \%$ 
Gráfico 27

Qual ato infracional ensejou a medida que está cumprindo?

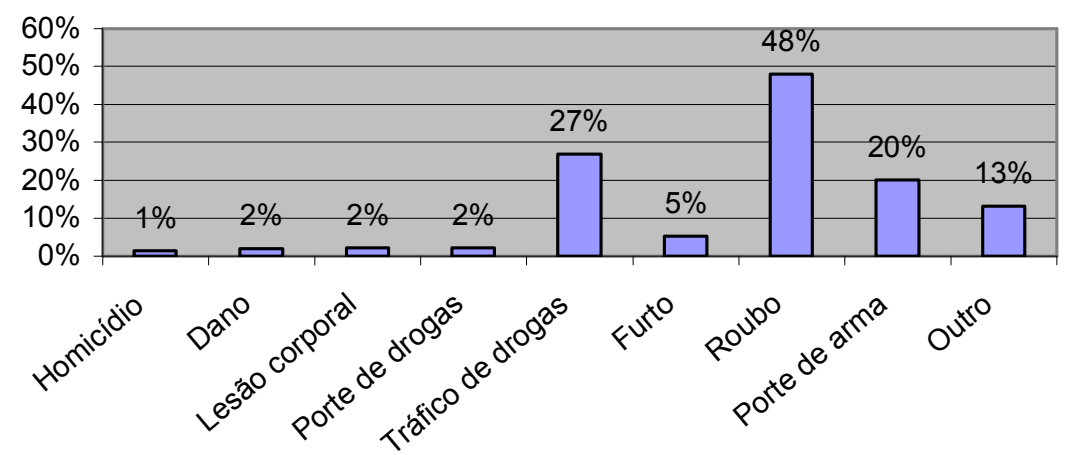

\section{Gráfico 28}

Qual a sua idade quando praticou esse ato infracional?

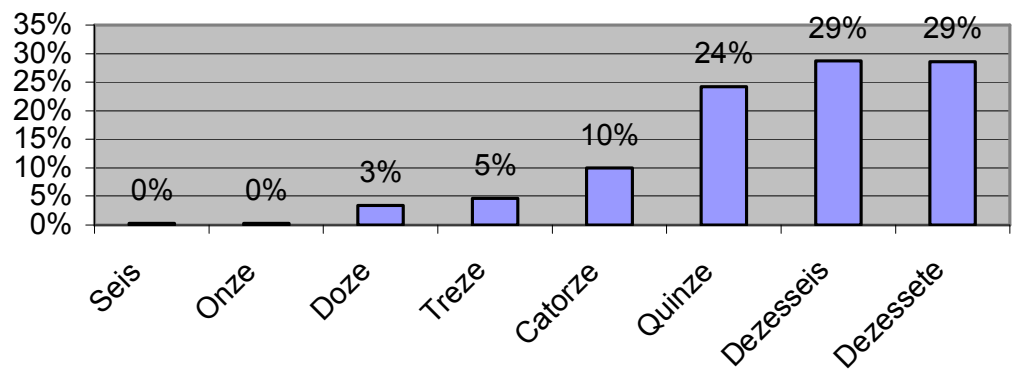

A seqüência trazida pelos gráficos 23 a 28 retrata a trajetória infracional desses adolescentes. Praticamente metade dos entrevistados é reincidente. Não temos como saber da outra metade já que a pergunta se refere aos atos infracionais pelos quais o adolescente foi julgado. É preciso, assim, assumir a possibilidade de que dentre a outra metade haja ainda aqueles que infracionaram, mas não foram julgados pela justiça.

Quase $30 \%$ já passaram pelo sistema FEBEM. Na pergunta que se refere ao ato anterior, as idades estão concentradas entre os 14 e 15 anos. Já na pergunta sobre o ato que resultou na medida atual a concentração desloca-se para os 16 e os 17 anos.

Os dados não mostram um agravamento dos crimes cometidos e desse modo, confrontam a hipótese do senso comum de que ao longo de uma "carreira no crime" os adolescentes naturalmente cometem crimes cada vez mais graves. 
Os números da reincidência evidenciam a ineficácia das medidas na sua tarefa de ressocialização. Paralelamente, a evolução das idades, a passagem pelo sistema, a sucessão de atos infracionais, mostram uma trajetória construída na delinqüência.

\section{Gráfico 29}

\section{Está matriculado?}

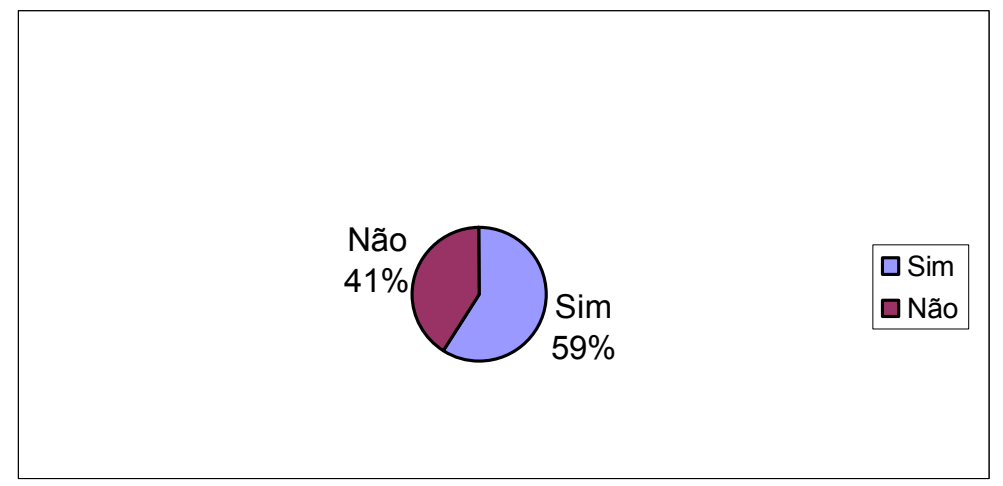

\section{Gráfico 30}

Com que frequiência vai às aulas?

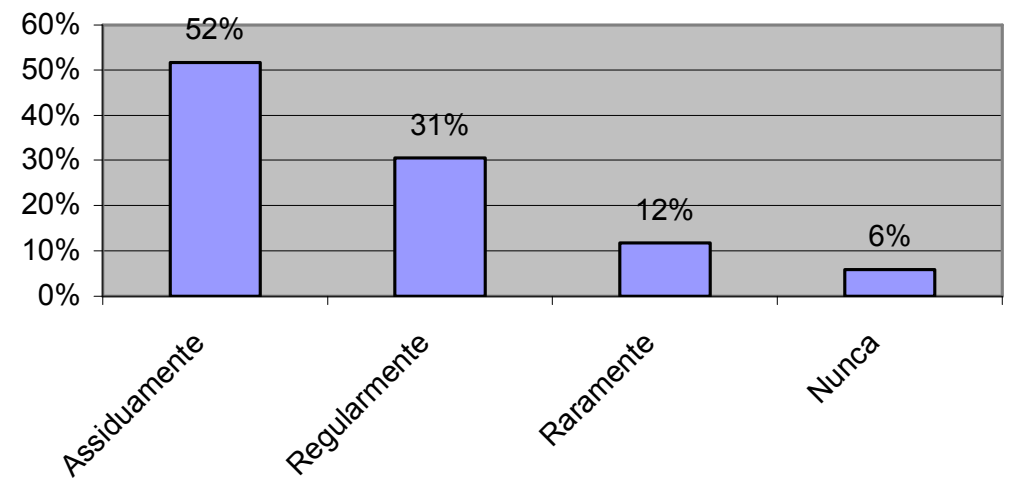

A frequiência escolar é o tema dos gráficos 29 e 30 . Pouco mais da metade dos adolescentes entrevistados (59\%) está matriculados na escola. Contudo, desse total, apenas 52\% afirmam que freqüentam a escola com assiduidade. Somados aos $41 \%$ que não estão matriculados, temos explicitado o apartamento do universo escolar na vida desses jovens. 
O dado ganha uma dimensão ainda mais grave no caso desse grupo de entrevistados em particular, uma vez que o ECA determina que o cumprimento de qualquer medida sócio-educativa deve ser acompanhada, obrigatoriamente, pelo estudo.

Essas informações dialogam com o universo das medidas em meio fechado. A pesquisa da Secretaria Especial dos Direitos Humanos, mencionada anteriormente com dados de 2002, revela que dos quase 10.000 jovens internados em todo Brasil, 51\% não freqüentavam a escola, e $90 \%$ dos internados não haviam completado o ensino fundamental, ainda que tivessem idade correspondente ao ensino médio ${ }^{200}$.

\section{Gráfico 31}

Você trabalha atualmente?

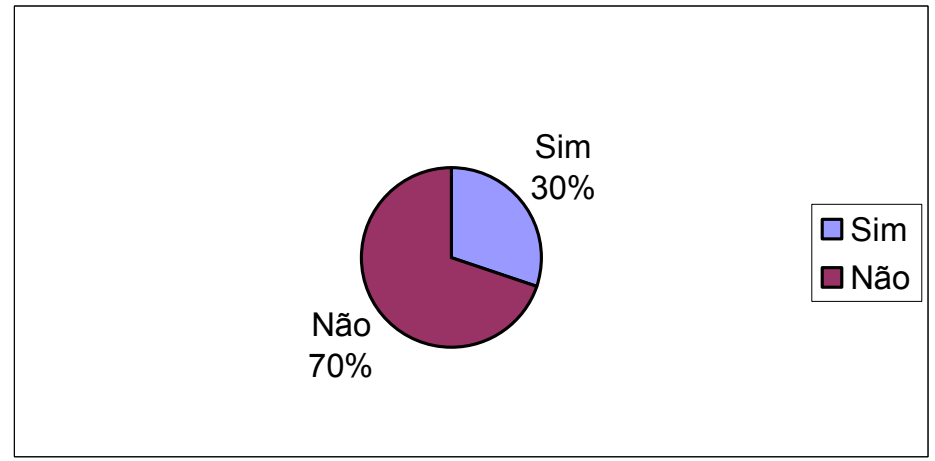

\section{Gráfico 32}

Você trabalha com carteira assinada?

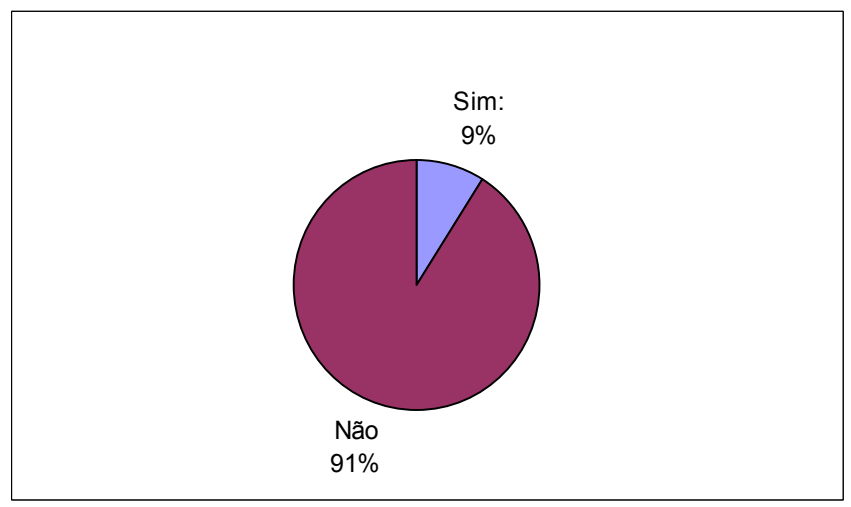

${ }^{200}$ Silva, Gueresi, 2003. 
Os gráficos 32 e 33 concluem a série de dados com informações sobre o mundo do trabalho, mostrando que apenas um terço dos jovens entrevistados estava empregado, mas quase a totalidade dos que responderam positivamente faz parte do mercado informal de trabalho ${ }^{201}$.

É preciso registrar que $81 \%$ dos entrevistados afirmaram já ter trabalhado anteriormente, sugerindo uma relação de intermitência com o trabalho, reforçada talvez pela fragilidade dos vínculos do mercado informal.

\section{Juventudes em disputa}

Nunca, em toda a história do país, tivemos um contingente populacional com tamanha predominância de jovens e crianças. Hoje, $20 \%$ da população brasileira encontra-se na faixa etária entre 15 e 24 anos; isto é, 34 milhões de jovens. Desse total, $84 \%$ (28,4 milhões) vivem nos centros urbanos, sendo que $31 \%\left(10,4\right.$ milhões) habitam as regiões metropolitanas ${ }^{202}$.

Tal crescimento fez que com que os jovens, assim como a própria juventude enquanto categoria, ganhassem visibilidade no cenário nacional. Hoje há um conjunto de políticas especificas destinadas a dialogar e a atender os problemas e desafios relativos à essa parcela da população ${ }^{203}$. Nos anos recentes, os jovens brasileiros vem aparecendo com destaque num grupo de estatísticas associadas ao desemprego, mortes, crimes, e gravidez indesejada. Com efeito, acesso ao mercado de trabalho, educação, maternidade precoce, protagonismo e participação, são alguns dentre os muitos temas fundamentais para pensar as condições nas quais vive a maioria dos jovens no Brasil, bem como tentar projetar suas perspectivas para o futuro.

De acordo com o censo demográfico do IBGE ${ }^{204}$ mais de 70\% dos jovens entre 15 a 29 anos vivem nos municípios urbanos.

\footnotetext{
${ }^{201}$ Uma etapa complementar da pesquisa Fundação Telefônica foi a pesquisa realizada pelo Instituto Fonte no mesmo período. O resultado "Estilhaços - vidas nas cidades em conflito (título provisório)". Ainda que não possa ser tomada como um dado propriamente, vale notar sobre o tema "trabalho" que em algumas entrevistas realizadas pelo Instituto Fonte, com esse mesmo grupo de jovens, as atividades desempenhadas pelos adolescentes no tráfico de drogas eram classificadas pelos mesmos como "emprego".

${ }^{202}$ Instituto Cidadania, 2004.

${ }^{203}$ Alguns exemplos são significativos nesse sentido. No primeiro ano do governo da prefeita Marta Suplicy foi criada uma Coordenadoria da Juventude, mantida pela gestão atual da prefeitura. Além disso, um dos maiores equipamentos públicos municipais de São Paulo atualmente é o Centro Cultural da Juventude na Vila Brasilândia. Em 2005, foi criado pelo Presidente Luiz Inácio Lula da Silva do Conselho Nacional da Juventude, órgão ligado diretamente à Secretaria Geral da presidência da República.

${ }^{204}$ IBGE, 2000.
} 
São Paulo capital tem uma população de 10.886.518 habitantes. Desse total, 1.415 .230 pessoas tem entre 12 e 18 anos. Ou seja, praticamente 13\% da população total do Estado está compreendida nessa faixa etária.

Ainda segundo os dados do IBGE, São Paulo ocupa o $1^{\circ}$ lugar no ranking de população jovem do país seguido por Rio de Janeiro, Salvador, Fortaleza e Brasília.

Os dados do Estado de São Paulo também são significativos: de acordo com a Fundação SEADE, do total de 38.718.301 habitantes, 6.470.803 têm até 9 anos de idade. Uma população de 3.282.053 localiza-se na faixa etária compreendida entre 10 e 14 anos: 3.529.856, entre 15 e 19 e 3.669 .383 entre 20 e 24 anos. Em outras palavras, 44\% da população do Estado têm até 24 anos.

Mas mesmo que seja possível recortar esse grupo populacional tendo como referência a faixaetária, a juventude, assim como a infância, são tradicionalmente tratadas, sobretudo pelas Ciências Humanas, como construções culturais; como variações sociais ao longo do tempo. Há uma extensa produção bibliográfica que faz uma revisão do conceito na história, deixando claro que a fase da vida caracterizada pela juventude, nos moldes em que conhecemos hoje, é inaugurada na sociedade ocidental moderna ${ }^{205}$.

O clássico trabalho de Philippe Ariès, História social da criança e da família ${ }^{206}$, uma referência para as reflexões nesse campo, mostra as variações históricas e sociais do fenômeno que o autor chama de "sentimento de infância" e da própria juventude enquanto categoria. Ao refazer o percurso de ambas as noções desde a Idade Média, o historiador Francês elege a escola e a família como elementos que delimitaram o mundo infantil em contraposição ao adulto.

Ariès relata que a partir do século XVIII, o ciclo escolar passa a ser diferenciado por um sistema duplo de ensino, o liceu e a escola, sendo o primeiro exclusivo aos burgueses ${ }^{207}$. Esse período estendido da escola era o que circunscrevia a juventude como passagem para a vida adulta e dava margem, portanto, a duas percepções da infância: uma que salta direto para a vida adulta e outra que tem esse período explicitado no prolongamento de seus anos escolares.

Outra referência clássica, Michel Foucault, identifica o processo de inscrição do social no corpo por meio da disciplina, da moral e da higiene, e também como forma de preparação para a vida adulta $^{208}$. O filósofo francês aponta as transformações da infância já no final do século XVIII, implicando mudanças nas relações físicas, espaciais e estruturais no projeto social daquilo que era

\footnotetext{
${ }^{205}$ É preciso citar aqui o trabalho de Cardoso e Sampaio (1995). Além de um compêndio de referências bibliográficas sobre "juventude" e seus sub-temas, as autoras fazem uma revisão importante do conceito nas Ciências Sociais ao longo do tempo.

${ }_{206}$ Áries, 2003.

${ }^{207}$ Idem: 193.

${ }^{208}$ Foucault, 1979.
} 
entendido como família, para incorporar o lugar social do filho e da própria infância nessa nova configuração.

Trabalhos mais recentes, com alguns que serão discutidos aqui, aludem a essas referências, atualizando o debate sem deixar de incorporar a subjetividade enquanto dado constituinte da categoria.

Com efeito, as definições atuais de juventude encontradas na literatura resultam de uma sobreposição de abordagens, informadas pela demografia, psicologia, antropologia entre outras, capazes de compreender e retratar as transformações sociais, psicológicas e físicas que caracterizam esse período ${ }^{209}$. Juventude seria assim um processo social mais do que uma categoria etária.

Alguns marcadores como escola, mercado de trabalho e maternidade ajudam a criar referências que delimitem esse período no interior de um ciclo de vida. Nesse sentido, a juventude também é um período de demarcação das diferenças de gênero. Vimos, por exemplo, como a vulnerabilidade social se expressa de modo diferente nos jovens do sexo masculino e nas meninas, opondo homicídios a maternidade precoce.

A transformação dos termos e dos tempos em que se dão esses processos, ou seja, a antecipação ou retardamento de entrada no mercado de trabalho ou da maternidade, por exemplo, podem reduzir ou prolongar o período caracterizado como juventude.

A UNESCO propõe, ainda, uma distinção entre juventude e adolescência, expressões que normalmente são usadas de forma indistinta. Juventude teria um sentido coletivo e dinâmico, contemplando os aspectos mais sociais. A adolescência, por sua vez, estaria atrelada aos processos biológicos e transformações fisiológicas e por isso, seria uma categoria mais apropriada para falar do indivíduo e de sua cronologia pessoal ${ }^{210}$.

Mas sejam as referências biológica ou sociais, coletivas ou individuais, o fato é que hoje essa é uma categoria elástica. Não por acaso as idéias de processo, provisório e transitório, estão associadas à ela. A classificação etária também espelha essa flexibilidade: na bibliografia citada nesse trabalho já foram classificados como jovens aqueles entre 15 e 24, entre 15 e 29, e entre 15 e 36. Temos ainda uma legislação para quem os adolescentes são os indivíduos entre 12 e 18 anos. O resultado é que podemos apenas falar em "juventudes", sempre no plural.

Tal pluralidade não permite tampouco que falemos numa juventude genérica. Góticos, Punks, estudantes universitários, grafiteiros, playboys, entre infinitos outros, formam grupos juvenis

\footnotetext{
${ }^{209}$ Abramovay, Castro: 2006a.

${ }^{210}$ Waiselfisz: 2004b.
} 
particulares, com identidades juvenis fragmentadas, produto de contextos e interações culturais específicas $^{211}$.

As pesquisas desenvolvidas e coordenadas por José Guilherme Magnani e o grupo de pesquisadores do NAU (Núcleo de Antropologia Urbana) procuram mapear tais grupos, suas redes de sociabilidade e práticas de lazer na cidade, particularmente em São Paulo ${ }^{212}$. Tais abordagens abrem mão do debate em torno da juventude na sua condição de categoria sociológica, para tomá-la como um dado empírico que orienta o recorte das pesquisas em questão.

Revisitando a bibliografia sobre o tema, Maganani opõe os termos "tribos urbanas" e "culturais juvenis". 0 autor propõe um terceiro caminho que chama de "circuito de jovens"; categoria que privilegia sua inserção no contexto urbano, articulando, assim, as dimensões de comportamento e espaço. O resultado é um inventário sobre tais circuitos: straight edges, Pichadores, Freqüentadores de Forró Universitário, entre outros. Por meio das categorias "relações de aproximação" e "evitação" as diversas pesquisas descrevem como vivem esses grupos, e de que maneira os jovens se relacionam entre si e com a cidade.

Nas palavras do autor, "Cada um desses arranjos corresponde a uma forma específica de se expor, estabelecer laços, marcar diferenças, fazer escolhas, colocar-se, enfim, na paisagem urbana diante dos outros e em relação a eles ${ }^{213}$ ".

Além de um retrato da diversidade daquilo que pode ser classificado como "cultura juvenil", o que tais estudos sugerem é que há maneiras possíveis de viver a experiência da juventude, e que os limites dessa experiência são pautados pelos processos de interação com a cidade, com seus pares, com os espaços públicos e privados.

Mas voltemos à referência de Ariès uma vez mais. Nos interessa contemplar as possibilidades de variação da categoria no interior de uma mesma sociedade, num mesmo período histórico, assim como os elementos e processos associados a essa variação.

No conjunto das "juventudes" que co-existem, é preciso reconhecer, diante do dado de que as vítimas preferenciais da violência são jovens, pobres, negros e pardos, moradores das periferias dos centros urbanos, que hoje há uma forma particular de viver a juventude: morar num bairro de periferia onde a violência, além de uma forma de comunicação, configura um conjunto de padrões de sociabilidade.

\footnotetext{
211 Abramo, 1994.

212 Magnani, 2005.

${ }^{213}$ Magnani, idem: 203.
} 
Estamos falando de um tipo de experiência juvenil associada ao que comumente chamamos de exclusão social que, como vimos a partir dos dados apresentados, tem no seu repertório o acesso a arma de fogo, o consumo de drogas lícitas e ilícitas, familiaridade - seja por meio da experiência pessoal ou de alguém próximo - com a delinqüência, distância do mercado de trabalho, sobretudo o formal, além das privações de ordem econômica.

Obviamente seria equivocado e ingênuo assumir que a experiência de juventude desses meninos está restrita ao universo pintado pelos dados. Não lhes foi perguntado, por exemplo, nada sobre suas práticas de lazer ou gostos culturais; o que certamente retrataria uma existência mais plural.

Mas, em primeiro lugar, a violência é um tema capaz de acessar muitos outros, e, nesse sentido, pode ser um bom ponto de partida para procurar marcadores sociais de uma determinada sociabilidade juvenil. Em segundo, a maneira pela qual os jovens ingressam no universo adulto é um elemento fundamental e determinante do seu futuro. E o panorama construído pelos dados mostra processos sucessivos de exclusão que reduzem a diversidade de escolhas possíveis e, em muitos casos, implicam até a própria brevidade da vida desse jovem.

Retomando a categoria de Magnani, assim como os punks, os jovens evangélicos, os cybermanos, o que esse "circuito de jovens" (que ironicamente circulam muito pouco além da própria periferia) que morrem e que se envolvem no crime está expressando sobre a nossa sociedade?

Do ponto de vista das relações sociais, Alba Zaluar ${ }^{214}$ identifica a entrada no tráfico de drogas como um marco do ingresso dos jovens no crime organizado. A autora, pioneira nas incursões etnográficas ao universo da violência nas favelas cariocas e suas ligações com a criminalidade urbana, tem no conjunto dos seus estudos, um mapa fundamental para compreender as dinâmicas engendradas por tais processos.

É possível, a partir do conjunto obra de Zaluar ${ }^{215}$, abstrair um modelo de relações sociais complexas que congrega padrões de masculinidade, acesso irrestrito a armas de fogo, as relações entre jovens de ambos os sexos e novos símbolos de status nesse universo particular. Esse modelo subsidia a construção das imagens do crime e do poder.

Enquanto suporte onde são travadas relações, esse modelo também está sujeito a transformações constantes em função das mudanças no mercado da droga, da atuação da polícia, que pode ser mais ou menos violenta de tempos em tempos, e das próprias práticas criminosas ${ }^{216}$.

\footnotetext{
$2141994 \mathrm{c}$.

215 1994a, 1994b, 1994c, 1998.

${ }^{216}$ Alvito, 1999.
} 
De maneira paralela ao universo descrito por Zaluar, estamos também falando de jovens vivendo em regiões pobres, envolvidos com algum tipo de criminalidade, e em certos casos praticando ou sendo vítimas de mortes violentas. Há uma série de elementos comuns nos cenários descritos: o fácil acesso à arma de fogo, um ambiente de privações, a situação de risco e a fronteira frágil entre o certo e o errado, o lícito e o ilícito. Os elementos explicativos comuns também podem ser muitos: a ação coletiva, a necessidade de pertencimento, ou a delimitação de lugares sociais a partir de oposições. 0 objeto de disputa, nesse caso, são bens, prestígio, ou algum outro tipo de benefício real ou simbólico.

Luiz Eduardo Soares opta por enfatizar o papel da arma de fogo. Para o antropólogo, ela é um elemento particular que conecta as práticas desses jovens à violência. “Um dia, um traficante dá a um desses meninos uma arma. Quando um desses meninos nos parar na esquina, apontando-nos essa arma, estará provocando em cada um de nós um sentimento - um sentimento de medo, que é negativo, mas é um sentimento. Ao fazê-lo, saltará da sombra em que desaparecera e se tornará

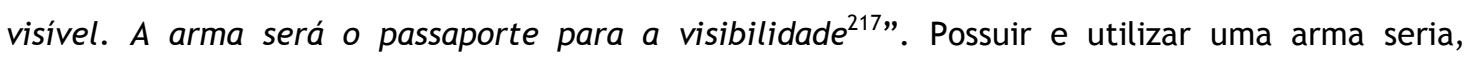
portanto, uma forma de ganhar um novo lugar, um meio para romper a invisibilidade. Esses jovens adquirem o status de "sujeito" quanto nos ameaçam. Essa conquista, que é resultado também de um cenário de medo e violência, se dá por meio da produção de doses ainda maiores de medo e violência.

O ciclo fica ainda mais complexo (e perverso) quando consideramos que as principais vítimas desse cenário são os próprios jovens. 0 que estaria sendo reivindicado nesse caso?

O termo "epidemia", importado da Saúde Pública, é usado de forma corrente, mesmo fora desse campo epistêmico, para falar da violência. Originalmente, trata-se um termo técnico ou mais uma forma de identificar causas de lesões ou de mortalidade ${ }^{218}$. Mas hoje já foi apropriado como referência sociológica, sugerindo que há uma dimensão contagiante na violência.

A idéia de que seria possível "pegar violência", tal como se pega uma doença ou ser contagiado por ela, é perigosa ao passo em que dá margem a uma interpretação cravada por um enfoque do determinismo social. Por outro lado vimos que o envolvimento com a criminalidade é capaz de mobilizar e associar uma série de fatores tal como regras de sociabilidade e conduta, mobilidade ou a ausência de mobilidade, a relação com a cidade, a etiqueta das ameaças, as diferenças em relação à polícia, redes, formas de comunicação, impunidade, entre tantos outros. Com efeito, é preciso considerar a articulação de condicionantes estruturais, comunitários nessa conformação de

\footnotetext{
${ }^{217}$ Soares, 2005: 215. in Soares, Bill, Athayde, 2005.

${ }^{218}$ Para uma abordagem sobre os homicídios no Brasil sob a perspectiva da Saúde Pública, Cf. Peres, 2006.
} 
um contexto de maior risco em se tratando da possibilidade de envolvimento com o crime, de adotar práticas violentas (e de ser preso e/ou morrer) aos quais os jovens estão expostos.

A violência não é um tema exclusivo dos jovens. Mas assumindo que a juventude é um período que favorece a formação de redes em geral, incluindo redes de ilegalidades, ela (violência) torna-se um tema fundamental quando limita o trânsito dos indivíduos e faz com que construir um caminho alternativo ao do universo infracional não seja uma tarefa simples.

No livro intitulado "Traçando caminhos numa sociedade menos violenta: a vida de jovens infratores e seus irmãos não infratores ${ }^{219}$ ", Simone Assis, investiga e compara trajetórias de jovens que cometeram atos infracionais graves e seus irmãos ou primos que, submetidos a contextos muito semelhantes, não enveredam por uma carreira no crime. Trabalhando com os conceitos de "risco" e "resiliência", a autora procura "[...] identificar os fatores de risco que levam um jovem a ser infrator e os fatores protetores que agiriam sobre um outro jovem, que vive no mesmo ambiente familiar e comunitário, conduzindo-o a não optar por caminhos infracionais ${ }^{220 " . ~} 0$ universo investigado são jovens, do sexo masculino, internados em instituições onde cumpriam medida de internação em função do ato infracional cometido, no Rio de Janeiro e em Recife. Além dos jovens internos, foram entrevistados também seus irmãos e primos.

A análise das condições de vida dos entrevistados revela um panorama de vulnerabilidade e exposição aos chamados fatores de risco: situação de pobreza, desestruturação familiar, preponderando famílias onde havia a presença exclusiva das mães, o envolvimento de outros parentes com o universo do crime, baixo nível de escolaridade são alguns deles.

A relação de causalidade, todavia, é abandonada de imediato pela autora já que os irmãos e primos estiveram sujeitos a esses mesmos riscos e mesmo assim tiveram destinos diferentes.

Se por um lado, "a violência está impregnada nas suas vidas e parece funcionar como princípio ordenador de suas comunidades ${ }^{221}$ ", Assis vê espaço para diferenças apontadas no plano concreto que se resumem às escolhas seja das companhias, do uso ou não de drogas e também no que diz respeito aos seus planos para o futuro. Para a autora, trata-se menos de como a biografia familiar ou comunitária - é capaz de determinar a vida de cada um desses jovens, mas como a percepção individual que cada um tem da sua própria história é mais importante e relevante como elemento que orienta uma determinada postura em relação à vida.

${ }^{219}$ Assis, 1999.

${ }^{220}$ Assis, idem: 21.

${ }^{221}$ Assis, ibidem: 69. 
Além de um panorama empírico amplo e interessante, a pesquisa de Assis contribui para o debate sobre o envolvimento dos jovens com a criminalidade, articulando condicionantes estruturais à dimensão individual.

Nunca perguntei a Francisco o porquê das suas escolhas. Antes de mais nada porque não foi ele quem me contou do envolvimento de sua família com o crime. Mas, além disso, essa me pareceu sempre uma pergunta desconfortável, sobretudo porque provavelmente fazia sentido apenas para $\operatorname{mim}$.

Em larga medida, não se envolver com o crime já revela uma maneira de enxergar a vida no crime. Mas nossas conversas sobre outros temas também me deram pistas interessantes sobre seu modo de entender o mundo, suas prioridades e até mesmo suas escolhas. E nesse conjunto, obviamente, o crime emergia como temática, ainda que travestido de outros assuntos. Falar do destino de amigos desempregados era uma maneira de abordar o encontro entre as dificuldades impostas aos jovens moradores da periferia com a disposição de cada um para fazer sua “correia”, ou seja, para dar um jeito, achar um caminho para a própria vida. Para Francisco esse era um equilíbrio delicado. Não podia culpar os amigos pelo infortúnio, mas via em si mesmo alguém que, diante das mesmas dificuldades, conseguiu superá-las, indicando que outros poderiam fazer o mesmo.

Fazendo uma breve incursão à esfera das escolhas individuas como propõe Assis, é possível olhar para Francisco como alguém que estabelece relações de alteridade constantes com seu bairro, com seu universo social, com sua rede de conhecidos e até com a sua família. Ele foi sem dúvida o sujeito que mais procurou estabelecer uma relação simétrica comigo. Via de regra, nossos diálogos apoiavam-se nas poucas intersecções entre os nossos universos. Ao contrário dos outros moradores do PNSA, era raro conversarmos sobre algo ou alguém do bairro. Ele queria sempre saber da minha vida e me contar da sua; fora dali.

Nesse contexto, eu arriscaria que a ambição é um tema fundamental. Francisco tem ambições em muitos campos e elas se traduzem de diversas maneiras: mais visivelmente nas suas roupas, na sua moto nova, mas também nos programas que ele faz e deseja fazer, nos lugares que freqüenta, e até no tipo de namorada que almeja ter: "A gente tem que estar com alguém que empurre a gente pra frente e não que fique segurando a gente ou puxando para baixo", me disse Francisco quando me contava que havia terminado o namoro. A explicação para o fim do relacionamento estava concentrada no fato de que sua namorada há muito tempo tinha desistido de procurar emprego, ficava o dia todo em casa, sem fazer nada, não tinha o que conversar com ele, não tinha "vontade de fazer nada diferente".

Francisco, ao contrário, queria fazer tudo diferente. 


\section{Violências possíveis}

Felipe Estrada ${ }^{222}$ usa um argumento interessante para questionar o aumento da criminalidade juvenil na Europa e em especial na Suécia. Partindo do crescimento sensível das taxas de condenação de jovens nos anos 1980, o autor mostra como não foram os jovens que passaram a cometer mais crimes, mas a justiça que, desde então, vem sendo aplicada com mais vigor e de maneira mais punitiva em relação a esse grupo.

Cruzando pesquisas de vitimização, dados de internação hospitalar e estatísticas de homicídios, o sociólogo sueco mostra como seria preciso ter acesso a séries históricas por períodos mais longos do que as disponíveis para verificar se a criminalidade juvenil de fato aumentou ou se os dados apenas refletem uma mudança na percepção por parte da Justiça e da opinião pública que está mais atenta e sensível à essa modalidade de violência ${ }^{223}$.

Ainda segundo o autor, a oscilação da presença do tema na mídia entre os anos de 1950 e 1994 (período delimitado pela seleção de sua pesquisa) é um sensor do modo pelo qual a juventude é percebida e representada pela sociedade e, portanto, também pela mídia: uma trajetória que vai de criança problemática com uma família desestruturada, passando, posteriormente, pelo jovem educado, frio emocionalmente e imprevisível, para se consolidar na atualidade como um superpredador do qual a sociedade deve se proteger ${ }^{224}$.

O autor conclui chamando a atenção para a dimensão também ideológica que os discursos sobre o aumento do crime, assim como o aumento da criminalidade juvenil podem ter, sobretudo quando confrontados com as mudanças sociais e econômicas em curso nas sociedades ocidentais desde o início do Século XXI ${ }^{225}$.

0 argumento de Estrada nos interessa porque deixa claro como qualquer reflexão sobre o envolvimento do jovem com a criminalidade implica uma reflexão, na mesma medida, sobre o controle social da juventude.

${ }^{222}$ Estrada, 2001.

${ }^{223} \mathrm{O}$ autor sugere que análises sobre as tendências criminais em geral não devem se basear exclusivamente em estatísticas criminais, mas deve fazer uso de indicadores alternativos.

${ }^{224}$ No Brasil o Centro de Estudos de Segurança e Cidadania da Universidade Candido Mendes (CESEC) realizou recentemente uma pesquisa acerca da cobertura jornalística para a "criminalidade urbana". A pesquisa não se propôs a analisar o conteúdo do discurso da mídia sobre a violência no país e seu conseqüente impacto no público leitor, mas sim indicar as tendências da cobertura de nove jornais - Folha de São Paulo, O Estado de São Paulo, Agora São Paulo, O Globo, Jornal do Brasil, O Dia, Estado de Minas, Diário da Tarde e Hoje em Dia - quando o tema era violência e segurança pública. As conclusões dão pistas interessantes sobre como a seleção editorial feita pela mídia expressa suas opções de tratamento para o tema. Mas não apenas isso, ainda que esse não tenha sido o objetivo central do estudo, deixam claro a magnitude do objeto.

${ }^{225}$ Idem: 653 . 
A "violência criminal juvenil" é, na verdade, um objeto indefinido. Sua classificação é feita $a$ posteriori e acompanha as variações da própria categoria juventude. No Brasil, por exemplo, essa indefinição é encerrada por uma legislação específica, que distingue os atos cometidos por indivíduos com menos de 18 anos dos crimes, classificando-os como "atos infracionais" ${ }^{226 " . ~ M a s ~ e l a ~}$ pode ter outras conotações em países com uma legislação distinta.

Mas, para além de sua classificação jurídica, de que outras formas a violência juvenil é caracterizada?

A mudança das dinâmicas no ambiente escolar é um exemplo interessante para explorar a subjetividade na delimitação do que pode ser classificado como violência criminal juvenil. Violência nas escolas não é um tema propriamente novo. A novidade, como mostram pesquisas recentes desenvolvidas no Brasil, são as mudanças no tipo de violência que vem sendo praticada no interior dos estabelecimentos de ensino: presença de armas brancas e de fogo, ameaça e agressões recíprocas entre alunos e professores, roubos, violência sexual entre alunos e depredação do espaço institucional são alguns exemplos ${ }^{227}$. Podemos dizer, portanto, que a escola deixou de ser um espaço essencialmente protegido, para se tornar um lugar mais permeável aos padrões de violência da comunidade onde está inserida. Diante dessa mudança nos padrões, o conjunto de conflitos, mesmo aqueles que seriam próprios do ambiente escolar, deixa de ser um problema disciplinar para se converter em mais uma questão de segurança pública. Se por um lado, há de fato um agravamento do tipo de violência que é praticada pelos alunos, professores e pela comunidade escolar como um todo, por outro, esse mesmo agravamento acaba comprometendo uma leitura mais precisa do limite entre o que seriam crimes (ou os atos infracionais, no caso brasileiro) e, portanto um assunto para a polícia e para a justiça, e o que seriam conflitos para serem administrados no interior e pela própria comunidade escolar. A exacerbação da violência provoca, entre muitos outros efeitos, a perda dessa nuance capaz de fazer a leitura particularizada que tais eventos demandam. A combinação entre as muitas agressões, a perda de autoridade por parte dos professores e o medo reduz não apenas capacidade de resolução dos conflitos independente do seu grau de gravidade, mas mina a crença de que é possível resolvê-los.

Mas é preciso salientar que os processos que atrapalham a percepção não são construídos no vazio. Eles são alimentados diariamente por episódios violentos, capazes de reificar as construções sociais sobre o crime e o criminoso. Como já foi explorado em capítulos anteriores, o medo e a sensação de insegurança são elementos poderosos nessa equação.

\footnotetext{
${ }^{226}$ Para uma revisão sobre o ECA num debate jurídico sob a perspectiva do "Direito Penal Juvenil", ver Sposato, 2006.

${ }^{227}$ Abramovay, Rua, 2002.
} 
A violência vivida e a violência percebida, associadas às expectativas que ambas criam em relação a comportamentos possíveis, dificulta a separação desses discursos. Identificar um equilíbrio nesses processos, sem desprezar, nenhuma dimensão, é uma tarefa cercada de tensões.

Os dados mostram que o envolvimento dos jovens com a criminalidade não é preponderante quando considerado o conjunto total da população. Paralelamente, segundo os dados da Fundação CASA, os crimes contra o patrimônio correspondem a mais de $50 \%$ do universo da internação, quadro que se repete no universo do meio aberto que a pesquisa do llanud retrata. Os dados nacionais mostram um envolvimento um pouco maior dos jovens com menos de 18 anos com os homicídios cometidos.

Ao mesmo tempo, como viemos afirmando ao longo de todo esse trabalho, e como mostram os estudos na área, são os jovens, entre 15 e 24 anos as maiores vítimas de homicídios no Brasil.

Soma-se a isso o fato de que a gravidade e o horror associados (e veiculados) aos crimes cometidos por jovens vêm aumentando. Esse poderia ser a tendência, já identificada por Adorno ${ }^{228}$, segundo a qual a criminalidade juvenil acompanha as transformações dos padrões de violência em geral. Mas, além de acompanhar, sabemos, por meio dos processos assinalados anteriormente, que elas também contribuem para que estes sejam alterados.

Os impasses sobre a alternância entre os papéis de vítima e de algoz já foi apontado pela literatura ${ }^{229}$, mas perece ainda ser um tópico relevante para o debate. No caso das crianças, sua condição de vítima é mais evidente e menos controversa.

No relatório final do Estudo Global para as Nações Unidas sobre a violência contra a criança, realizado por Pinheiro ${ }^{230}$, são apontadas as formas mais tradicionais de vitimização violenta de crianças ao redor do mundo: homicídios, mutilação genital, abuso e violência sexual, bullying, trabalho infantil, trabalho forçado ou escravo, são algumas das modalidades encontradas pela pesquisa. Ainda que o estudo inclua no seu recorte "criança", jovens com menos de 18 anos, o que se sobrepõe aos limites da categoria juventude, o relatório final não se refere em momento algum à violência praticada pelas crianças (nesse caso jovens com menos de 18 anos), preferindo retratar a violência institucional, seja da polícia, das instituições de internação, a violência sofrida na escola ou na comunidade e ainda a violência no interior da família.

Essa cisão está refletida, inclusive, na delimitação dos campos de atuação das políticas públicas. Os jovens em conflito com a lei são objeto de interesse e de intervenção das políticas de

\footnotetext{
${ }^{228}$ Adorno, Lima, Bordini, 1999.

${ }^{229}$ Idem; Gregori, 2000.

${ }^{230}$ Pinheiro, 2005.
} 
promoção dos direitos da criança e do adolescente. Já os crimes praticados e, numa escala menor de interesse, sofridos pelos jovens com mais de 18 anos passam a ser, automaticamente, alvo das ações, mesmo que de prevenção, no campo da segurança pública. Mas será que há de fato uma separação tão evidente entre esses dois universos? Será que estamos falando de grupos distintos de jovens?

A sobreposição das categorias etárias - adolescentes entre 12 e 18 anos e jovens entre 15 e 24/29 cria alguns problemas de ordem metodologia e interpretativa. Em primeiro lugar, os dados não nos permitem avaliar a proporcionalidade das mortes ao longo das idades. Temos pistas dispersas: segundo o DHPP os autores e vítimas estão concentrados entre 18 e 24 . Mas essa é só uma parte da análise e refere-se à realidade da Zona Sul de São Paulo.

Os dados da Fundação Seade nos informam a idade da vítima, mas não do autor dos homicídios. Muitos dos crimes, como vimos, pressupõem relações prévias de convivência entre autor e vítima. Mas isso não é suficiente. Há um vácuo de informação importante que faz com que saibamos muito pouco sobre o perfil dos autores desses crimes.

Os dados da Fundação CASA tampouco sugerem que sejam os menores de 18 anos os maiores responsáveis pelos homicídios. Mas os mesmos dados mostram que há um contingente expressivo de internos que não se classifica como pobre, mas como classe média ou média baixa. A subjetividade de tais categorias e o fato de que os dados são produzidos pela própria Fundação, impõem cautela às considerações que serão feitas a partir daqui.

Se de acordo com Estrada a ação da justiça pode influenciar a percepção da dimensão da criminalidade juvenil (no caso retratado pelo autor ela é supervalorizada), é preciso assumir que o mesmo pode acontecer no sentido inverso.

Em outras palavras, estamos falando de jovens pobres matando outros jovens pobres, em contextos onde a Justiça se mostra incapaz de alcançar. Essa hipótese não parte da premissa de que é preciso criminalizar ainda mais os jovens, mas, ao contrário, assume que eles podem estar sendo duplamente vitimizados.

O fato é que não sabemos e sem poder fazer uso dos dados, o debate acaba restrito à sua dimensão política e principiológica, como é comum nessa área.

As encruzilhadas dos direitos humanos e da própria militância quando o assunto é a vitimização não é um dilema novo para as pesquisas acadêmicas. Num outro contexto, Gregori revela a complexidade e ambigüidade que o lugar de vítima pode conjugar ${ }^{231}$.

${ }^{231} 1993$. 
Ainda assim, vale a pena perguntar quais são os tipos de crimes tolerados pela nossa sociedade e de que modo isso influencia não apenas a construção social do criminoso, mas também da vítima.

O processo de criminalização das classes mais pobres já foi amplamente diagnosticado pela literatura brasileira ${ }^{232}$. Podemos incluir nesse processo o recorte etário e pensar na não-vitmização como um processo simultâneo de criminalização.

O tipo de crime cometido é um indicativo precioso nesse sentido. Cometer um ato infracional não faz de alguém um homicida em potencial. Mas separar os grupos dessa forma é separar contextos, como se não houvesse nenhum ponto de contato.

Ainda que "juventudes" e "adolescências" tenham demandas específicas em muitos campos, é preciso pensar num panorama contíguo quando o tema é a violência praticada contra e pelos jovens.

Se não há uma leitura unívoca do que é juventude, há um consenso na literatura e mesmo na maneira como a sociedade enxerga os jovens quanto ao status diferenciado. Tal situação se verifica porque eles são tidos como pessoas em desenvolvimento e porque, como no caso brasileiro, estão sujeitos à uma legislação especial que, privilegia a reeducação em detrimento da punição exclusivamente.

Em se tratando, particularmente da aproximação dos jovens com a violência, como nota Frankling Zimring $^{233}$, esse lugar excepcional no interior da sociedade tem implicações práticas além da proteção legal: faz com que, ou deveria fazer, acreditemos no seu potencial de desenvolvimento e transformação. Nesse sentido, a ligação dos adolescentes ou jovens com o crime não é vista como algo consolidado, mas pode ser lida como um dado de transitoriedade, junto com tantos outros que caracterizam essa etapa da vida.

O que estamos assistindo, contudo, é que muitos desses sujeitos não sobrevivem o suficiente para ultrapassar essa fase ou, sua reincidência no crime, e o retardamento da entrada na vida adulta, não lhes dá as condições necessárias para superar essa etapa de juvenil que, nesse caso, é caracterizada pela associação com o universo infracional.

Nesse processo complexo, o jovem oscila entre a responsabilização absoluta e destituição completa de culpa. No segundo caso, as condições sociais, a ausência da escola, a família desestruturada - mas nunca o próprio jovem - são responsabilizadas. Tal situação é injusta com

\footnotetext{
${ }^{232}$ Zaluar, 1999.

${ }^{233} 1998$.
} 
todos os outros jovens, a grande maioria afinal, que está submetida às mesmas condições e não se envolvem com a criminalidade.

Por outro lado, a leitura que privilegia a responsabilização não considera, em primeiro lugar, os números de jovens mortos, dignos de um genocídio. Além disso, não parece ser capaz de compreender como essa relação, ainda que expressa pontualmente no crime cometido, em muitos casos, tem um lastro num cenário montado de maneira processual, ao longo da vida desses jovens, nas suas relações familiares, nas interações com os muitos círculos sociais e, claro, nas suas condições de vida.

No caso de Francisco, a despeito de sua proximidade com o crime, ele foi capaz de buscar e criar circuitos alternativos de convívio e interação social dentro e fora do bairro. 0 emprego e o lazer longe da periferia, mesclados com a convivência com amigos antigos do bairro the proporcionaram a própria possibilidade de transitar entre esses dois universos.

A expressão "redes de proteção social”234 é usada para nomear o conjunto de serviços disponíveis para minimizar ou aplacar a situação de risco de populações vulneráveis (jovens, mulheres, crianças, idosos). Mas ela nos serve também como um mote de reflexão num outro sentido. É possível pensar como a difusão da violência e seu caráter impregnado no cotidiano, potencializam a conformação de redes de ilegalidade da quais, mesmo aqueles jovens cujo engajamento seja relativo, parecem ter dificuldade de sair ou mesmo de estabelecer redes alternativas.

Assumindo o diálogo entre essas redes, o próximo capítulo procura explorar de que maneira a violência está sendo incorporada ao nosso cotidiano e quais as mudanças impostas às dinâmicas culturais de uma sociedade que aparentemente está disposta a conviver com ela.

\footnotetext{
${ }^{234}$ De acordo com Política Nacional de Assistência Social, "a proteção social deve garantir as seguintes seguranças: segurança de sobrevivência (de rendimento e de autonomia); de acolhida; de convívio ou vivência familiar" (2004: 29). A execução dessa política deve ser descentralizada e praticada pela "rede de proteção social". Essa rede seria formada pelas entidades prestadoras de assistência social nos níveis federal, estadual e municipal, por organizações não governamentais e comunitárias, a escola, a família e a própria comunidade.
} 


\title{
Capítulo 4
}

\section{Sociedade e Estado - as dimensões coletivas e individuais da violência}

\author{
"O verdadeiro problema não é estudar como a vida humana \\ se submete às regras - ela simplesmente não se submete -, \\ o verdadeiro problema é saber como as regras se adaptam à vida"
}

(B. Malinowski em Crime e Costume na Sociedade Selvagem, 2003)

O distrito do Jardim Ângela é atendido por duas delegacias da Polícia Civil: o $47^{\circ}$ Distrito Policial, no bairro vizinho do Capão Redondo e o $100^{\circ}$ Distrito Policial, no Jardim Herculano, também na fronteira do Ângela. Ambas dividem os atendimentos da região que não tem nenhuma delegacia localizada no próprio bairro.

Além das delegacias, ao longo da estrada do M'Boi Mirim e suas adjacências estão localizadas mais duas bases comunitárias da Polícia Militar. As duas não se mostram distanciadas do Parque Novo Santo Amaro, sendo que uma delas localiza-se na própria M'boi, a menos de 1 $\mathrm{km}$ da rua que dá acesso ao bairro.

No entanto, durante os três anos e meio em que freqüentei o PNSA e até os dias de hoje, nunca vi uma ronda da Polícia Militar no local, ainda que esta seja uma das suas atividades e atribuições. Tampouco, a despeito do número elevado de assassinatos registrados na região, encontrei uma equipe de investigação da Polícia Civil.

Se meus desencontros não podem ser tomados como referências absolutas de relevância numérica ${ }^{235}$, meus encontros, esses sim, bem como as histórias que escutei sobre outros encontros com a polícia, são um bom ponto de partida para compreender como as instituições de uma maneira mais ampla estão costuradas à violência referida ao longo desse trabalho, e

\footnotetext{
235 Ainda que tudo indique o contrário, até mesmo a fala dos moradores, como não morei no Parque Novo Santo Amaro, tenho que assumir a possibilidade de que ambas as polícias tenham estado lá inúmeras vezes, coincidentemente sempre na minha ausência.
} 
como o sentimento de justiça local, aquilo que Clifford Geertz definiu como fazer justiça em contexto ${ }^{236}$, encarna as contradições e ambigüidades dessas relações.

Era um sábado e eu havia marcado uma reunião na Associação de Moradores com o intuito de organizarmos nos próximos meses uma atividade comunitária em conjunto. Essa era a primeira vez que meu irmão me acompanhava na visita. Na sua qualidade de médico, eu havia pedido para que ele fosse à reunião a fim de conversar com alguns moradores que já haviam se queixado de problemas de saúde e estavam com dificuldades em relação ao posto de saúde da região.

Como de costume virei à direita na padaria e logo estava na primeira ladeira de acesso ao bairro. Dessa vez, entretanto, minha viagem foi mais curta: já na esquina seguinte nos deparamos com oito viaturas da Polícia Militar, sendo uma delas um camburão.

A cena era assustadora. Os policiais estavam dentro dos carros, mas mantinham suas armas penduradas para fora das janelas, apontando aleatoriamente enquanto gritavam ameaçando as pessoas que moravam ou circulavam no local naquela hora. Entre uma abundância e variedade que iam de revólveres a metralhadoras, eu não era capaz de identificar com precisão cada uma das armas.

Fiquei imobilizada pelo medo e sem saber o que fazer. Se seguir em frente era impossível, simplesmente dar ré também me parecia uma saída extremamente arriscada. E se fôssemos mal interpretados pelos policiais? Afinal, eu não tinha a menor idéia do que eles estavam fazendo lá.

Ficamos parados dentro do carro por alguns minutos. Finalmente sinalizei para um policial, indicando minha pretensão de sair dali. Aos poucos recuei para o começo da ladeira. Já longe dos carros de polícia, eu podia vê-los avançando para o interior do bairro.

Telefonei para as pessoas que me esperavam para a reunião. Todos sabiam o que estava acontecendo e me pediram para voltar para avenida e esperar. Cerca de 20 minutos depois um conhecido foi me buscar e nos acompanhou ao longo da descida.

\footnotetext{
${ }^{236} \mathrm{O}$ antropólogo norte-americano define o sentimento de justiça a partir de uma "sensibilidade jurídica" que contemplaria as bases culturais do direito (Geertz, 1998[2000]): 261).
} 
Eu esperava um caminho deserto, mas, ao contrário, os moradores estavam todos parados nas portas das suas casas. 0 grande número de pessoas nas ruas contrastava, contudo, com o silêncio reinante.

Ao longo do trajeto nosso acompanhante deus detalhes da operação: o objetivo da investida era prender um traficante local. 0 procurado, um menino de 16 anos, estava jogando bola no campo quando foi surpreendido e preso pela polícia.

Não presenciei esse encontro. Quando finalmente cheguei à Associação, ao lado do campo, o adolescente acusado já havia sido levado pela polícia.

A cena, no entanto, continuava montada: cerca de 15 policiais estavam e continuaram lá por mais uma hora, com as armas em mãos. Quando perguntei aos moradores a razão dessa atitude, esses me disseram que eles estavam lá para garantir que nenhum tipo de represália acontecesse. Enquanto isso, na beira do campo, um grupo de mulheres, (que mais tarde vim a saber eram a mãe e as irmãs do jovem que acabara de ser preso) choravam.

A aglomeração se dissolvia aos poucos e finalmente entramos na Associação para a reunião. Quando saí, os policias já não estavam mais lá.

A reunião foi longa, durou quase três horas. Minha impressão e, acima de tudo, minha sensação era de que estávamos todos, de alguma maneira, impressionados com a cena. Mas entramos sem dizer uma palavra a respeito do ocorrido nem meu irmão, nem eu, tampouco os participantes, e nenhum comentário foi feito durante toda a reunião.

Eu estava com medo, mas não sabia muito bem de que. Da polícia em primeiro lugar, sem dúvida. Mas também porque não sabia se algo aconteceria depois; alguma espécie de retaliação, por exemplo.

Mas o medo parecia ser privilégio meu (e do meu irmão, mas isso eu só descobri na volta, quando conversávamos no carro). Os moradores - é claro - não ignoravam o que acontecera. A reunião começou tímida e mesmo Seu João que sempre foi muito disposto a liderar as conversas e era quem, afinal, havia convocado o encontro, parecia não saber muito bem por onde começar ou como transpor o que havia acontecido do lado de fora. Mas no lugar do medo, a dificuldade parecia estar recheada muito mais de constrangimento, de vergonha da cena ocorrida envolvendo policiais e um criminoso na comunidade.

Entre os dias 12 e 15 de maio de 2006, São Paulo rendeu-se definitivamente ao pânico provocado pelos ataques da facção do crime organizado Primeiro Comando da Capital, o PCC, vivendo uma seqüência de eventos que se tornaria um marco na escalada da violência urbana 
em São Paulo. Durante esse breve período, 82 unidades prisionais paulistas foram palco de rebeliões simultâneas. Ao mesmo tempo, do lado de fora dos presídios, as forças de segurança do Estado de São Paulo sofriam sucessivos ataques com proporções inéditas. O conjunto de ações foi coordenado pelo Primeiro Comando da Capital, que estaria dessa maneira retaliando a decisão do Governo do Estado de São Paulo de isolar as lideranças do movimento por meio da transferência de seus integrantes. Entre os presos transferidos estava Marcos Willians Herba Camacho, o Marcola, apontado como líder do grupo, o qual transferido para o RDD (Regime Disciplinar Diferenciado) no presídio de segurança máxima de Presidente Bernardes, no interior do Estado de São Paulo.

Os ataques resultaram na morte de 23 policiais militares, sete policiais civis, três guardas municipais, oito agentes penitenciários e mais quatro civis. Nos presídios e CDPs (Centros de Detenção Provisória) outros nove detentos morreram durante as rebeliões.

Além das mortes, bases da polícia e da Guarda Municipal foram atacadas repetidamente na capital e no interior. Ônibus foram depredados e queimados em várias partes da cidade - só em São Paulo, quase 50 ônibus no total, segundo dados da SPTrans ${ }^{237}$.

Além da dispersão do medo e da violência pela cidade que ficou imediatamente deserta, os ataques resultaram, entre outras coisas, numa violenta ofensiva por parte da Polícia Militar, concentrada nas periferias de São Paulo, onde integrantes da facção criminosa e os envolvidos com os ataques eram procurados. 0 resultado imediato foi a transformação desses locais em verdadeiros campos de perseguição e batalha, submetendo o conjunto da população local a dias de terror, sobretudo de madrugada e à noite, quando saiam e voltavam do trabalho.

Exatamente uma semana depois dos ataques as represálias somavam um total de 109 mortes de acordo com os números divulgados pela imprensa ${ }^{238}$. As vítimas foram classificadas pela polícia como "suspeitos". O então secretário da Segurança Pública do Estado, Saulo de Castro Abreu Filho, ordenou o recolhimento dos laudos das mortes ocorridas em confrontos com a polícia. Os nomes das vítimas não foram divulgados e a investigação correu em sigilo. A justificativa para tais procedimentos, que violavam a lei e levantavam suspeitas sobre a legalidade das ações da polícia, era que qualquer medida no sentido contrário atrapalharia as investigações sobre o eventual envolvimento das vítimas com o PCC. Não há até hoje um laudo conclusivo sobre as mortes. Em outras palavras, não se sabe se algum dos mortos pela polícia tinha, em primeiro lugar, algum tipo de vínculo com a facção criminosa, tampouco se

\footnotetext{
${ }^{237}$ Empresa responsável pelo transporte público municipal de São Paulo.

${ }^{238}$ Valor Econômico, 24.5.2006. editorial
} 
as vítimas efetivamente reagiram à abordagem policial, se houve confronto, e se os policiais não poderiam ter detido essas pessoas ao invés de matá-las.

Foi nessa época e nesse contexto, no qual a maioria absoluta dos jovens moradores da periferia converteu-se em suspeitos, que Marcelo, junto com outro amigo, foram também abordados, intimidados e agredidos por dois policiais.

O que começou como um "enquadro" tradicional foi se agravando no decorrer da abordagem. Segundo Marcelo, os policiais estavam sem seus nomes na farda, procedimento que se popularizou durante o período das represálias, já que impossibilitava a identificação dos mesmos. Esse foi originalmente o tema da desavença entre eles. Ao ser abordado e receber a ordem de ficar de costas para a parede, Marcelo perguntou ao policial qual era o seu nome, já que não estava encontrando na farda. 0 policial respondeu que ele não precisava saber o nome dele, bastava obedecer. 0 diálogo tenso começava.

“- Devo te chamar de Seu polícia então?” respondeu Marcelo. A essa frase se sucederam agressões verbais contra Marcelo e seu amigo.

“ - Sou universitário, não sou bandido. E você seu polícia, estudou até que série?”. A revista continuou, mas agora de modo a agredir fisicamente ambos.

“ - Eu trabalho, ganho meu salário, e você, quanto você ganha Seu polícia?”. Marcelo chegou até mesmo a dizer ao policial o valor do seu salário.

Marcelo estava claramente se redefinindo para os policiais.

Andar com documento e preferencialmente com a carteira de trabalho é uma das estratégias conhecidas por jovens os quais vivendo na periferia, têm que se proteger dos "enquadros" da polícia. "Pé de breque de polícia" é a expressão que define o sujeito que tem os atributos para ser parado pela polícia para uma revista. O leque de qualidades que compõem um pé de breque é variado: cor da pele, tipo de roupa, presença de tatuagem, touca (gorro) ou boné, são alguns deles. Mas como já escutei dos próprios policiais, hoje em dia não dá mais para saber "só pela roupa" quem são os suspeitos e todos merecem, assim, uma abordagem.

Nesse contexto, um atestado de "trabalhador" é também, se não sobretudo, uma declaração de que "não estou no crime". Mas com suas afirmações (ou provocações), Marcelo estava fazendo mais do que atestar que não era criminoso: estava dizendo ao policial que dominava o léxico institucional; sabia que eles deveriam ter os nomes nas fardas e não os apresentavam intencionalmente. Estava afirmando mais: não era apenas um morador da periferia, era 
universitário e ganhava um salário melhor do que os próprios policiais e não se intimidava diante das suas ameaças.

Alguns dias depois, Marcelo encontrou um dos policiais, dessa vez sem a farda, numa padaria próxima à sua casa. $O$ encontro foi breve. Ambos se entreolharam sem trocar nenhuma palavra. Mas foi o suficiente para que Marcelo tomasse a decisão de denunciar o ocorrido. A presença tão próxima do policial fez com que Marcelo temesse que a agressão pudesse acontecer novamente, dessa vez de forma ainda mais grave.

Marcelo me ligou para contar o que havia se passado e pensarmos juntos qual seria a melhor saída a tomar. Entrei em contato com um advogado de uma ONG que presta assistência judiciária gratuita e, ainda na mesma semana, Marcelo e o advogado dirigiram-se à delegacia para fazer a denúncia contra os dois policiais. A próxima providência de Marcelo foi ir até o batalhão relatar o que ocorrera ao comandante e avisar que havia registrado uma queixa. Do meu lado, insistia que ele tivesse cuidado e achava que o episódio estava ganhando proporções muito grandes e, portanto, trazia riscos à sua própria segurança. Mas aos poucos pude entender que esse era precisamente seu objetivo: deixar o episódio o mais público possível. Na sua opinião, se havia alguma maneira de se proteger de outras agressões por parte dos policiais, essa era a melhor e talvez a única forma de agir.

O caso não teve mais nenhum desdobramento; Marcelo jamais foi abordado novamente por esses mesmos policiais, nem a queixa suscitou uma investigação.

Ainda que o tema da violência institucional tenha aparecido até agora de maneira marginal nesse trabalho, trata-se de um assunto fundamental para refletir sobre a violência no Brasil. A centralidade do assunto está expressa, por exemplo, no fato de que a atuação da polícia e a violência policial se constituíram como campo de estudo específico e pioneiro em se tratando de pesquisas sobre a violência no país ${ }^{239}$.

O interesse acadêmico ou investigativo deve ser compreendido de maneira a considerar que as forças policiais e sua atuação legal e ilegal foram durante muito tempo e são em larga medida até os dias de hoje, focos produtores de violência no Brasil. Mesmo com a transição democrática, o Estado brasileiro se manteve na condição de um dos grandes violadores de direitos, sendo seu braço policial uma das expressões mais acabadas desse traço ${ }^{240}$.

\footnotetext{
${ }^{239}$ Cf. Zaluar (1999) onde a autora mapeia criticamente as distintas abordagens nacionais no campo de pesquisa sobre criminalidade e violência no Brasil, por meio de uma extensa e completa revisão da produção brasileira entre 1970 e 1995.

${ }^{240}$ São muitos os exemplos da história democrática recente brasileira que ganharam status de emblemas das violações e abusos perpetrados pela polícia: o massacre do Carandiru em 1992, o massacre da Candelária em 1993, as referidas revanches dos ataques do PCC, e, mais recentemente a ação da polícia
} 
Mas além da corrupção e da brutalidade que caracterizam as forças policiais, Luiz Eduardo Soares ${ }^{241}$ resume as deficiências da polícia brasileira chamando a atenção para a combinação entre um desempenho ineficiente no que diz respeito a atuação de prevenção ou repressão qualificada, sua pouca capacidade investigativa e uma inaptidão em conquistar a confiança da população.

Do ponto de vista da gestão da atividade das corporações, Soares ressalta ainda que essas não trabalham com planejamento ou avaliação das suas atividades, são essencialmente reativas, operando num universo institucional fragmentado com pouca ou quase nenhuma articulação.

Além disso, as polícias não estão sujeitas ao controle externo de maneira rigorosa ${ }^{242}$, dificultando a apuração e punição das ilegalidades praticadas por membros da corporação. Um exemplo contundente nesse sentido é o fato de que até 1996, os casos de homicídios praticados por policiais militares eram julgados não na justiça comum, mas pelo respectivo Tribunal de Justiça Militar estadual. Foi apenas com a aprovação da lei 9.299, em 1996, que foi modificado o que previa originalmente o Código Penal Militar, determinando que os crimes praticados por um policial militar, quando dolosos, contra a vida e cometidos contra um civil, seriam da competência da Justiça Comum ${ }^{243}$. Hoje os homicídios dolosos são julgados na justiça comum, mas crimes de outra natureza ainda são julgados num tribunal militar.

A baixa qualificação dos policiais acaba de comprometer a qualidade do trabalho. Por fim, para além da pouca valorização ou reconhecimento do profissional, a situação é ainda mais agravada em função dos baixos salários recebidos.

È preciso notar, entretanto, que nos últimos anos houve avanços em relações à atuação das polícias em direção a um modelo mais condizente com o Estado democrático de direito.

Se não podemos ainda falar de uma polícia que respeita, garante e promove direitos de maneira plena e igualitária, também não é possível falar em "Polícia” de forma genérica. A heterogeneidade no interior e entre as corporações, as distinções entre a Polícia Civil e

no Morro do Alemão, em junho de 2007, no Rio de Janeiro, cujo saldo foi de 19 mortos. O relatório encomendado pela Secretaria Especial de Direitos Humanos da Presidência da República traz fortes indícios de que muitas das mortes podem ser classificadas como execução sumária, dado o número médio elevado de disparo por vítima, os locais dos disparos e o modo como foram feitos (pelas costas e próximas das vítimas).

${ }^{241} 2006: 100$.

${ }^{242}$ A criação e implementação das Ouvidorias de Polícia no país é um processo recente que vem se desenvolvendo lentamente. Hoje, contam com ouvidorias de polícia os estados de São Paulo, Pará, Minas Gerais, Rio de Janeiro, Bahia, Goiás, Mato Grosso, Pernambuco, Rio Grande do Norte, Ceará, Rio Grande do Sul, Santa Catarina, Espírito Santo e Paraná.

${ }^{243}$ Há um grande debate acerca da inconstitucionalidade da mudança. Os que estão de acordo com ela afirmam que não foi a lei que mudou, mas a natureza do delito. Isso é, o delito descrito pela nova lei deixou de ser militar para ser entendido como comum. 
Militar e mesmo as diferenças que definem a atividade policial entre os estados faz com que, em primeiro lugar, possamos observar transformações em curso no interior da polícia e, em segundo, que os policiais e as polícias são muito distintas entre si.

Assim como os cenários deflagrados pela "violência urbana" podem variar de cidade para cidade em função do tipo de crime cometido e da própria geografia da criminalidade, a atuação policial também. Sem tratar agora do tema da violação de direitos ou da corrupção, as doses de violência e letalidade que caracterizam as ações das corporações podem ser tomadas como bons indicativos nesse sentido. $03^{\circ}$ Relatório sobre Direitos Humanos no Brasil $^{244}$, produzido pelo Núcleo de Estudos da Violência da Universidade de São Paulo, lançado em 2007, registra que entre 2002 e 2005, 3.009 pessoas foram mortas por policiais em São Paulo e 3.970 no Rio de Janeiro. Comparando o número de mortos pela polícia no Rio de Janeiro e em São Paulo, algumas diferenças fundamentais ficam claras. Em 2006, a polícia carioca matou 1.063 civis. Esse número significou que para cada policial morto, 41 civis foram assassinados. Em São Paulo, também em 2006, ano em que as mortes provocadas pela polícia aumentaram em função dos ataques do PCC, essa proporção era de 1 policial para cada 14 civis. No caso do Rio, as mortes provocadas pela polícia correspondem a $14 \%$ do total de vítimas de violência letal intencional. Os índices internacionalmente tolerados ficam entre $1 \%$ e 3\%. Os números elevados não são capazes de explicar o complexo emaranhado institucional que, como vimos, carrega há muito tempo problemas estruturais, mas são suficientes para sugerir, de maneira contundente, que há abusos nas ações das forças policiais, e que estes têm resultado na morte indevida de civis. A comparação entre números das duas cidades ilustra as diferenças entre as práticas policiais nas duas localidades ${ }^{245}$.

\footnotetext{
${ }^{244}$ Mesquita Neto, Alves, 2007.

${ }^{245}$ As mortes provocadas por policias em São Paulo foram alvo de um debate acalorado por meio dos jornais entre Paulo Mesquita Neto (Folha de São Paulo, 7.02.2007) e Tulio Khan (Folha de São Paulo, 14.02.2007). Mesquita Neto, cientista político, apresentado no artigo como coordenador da área de Monitoramento dos Direitos Humanos do Núcleo de Estudos da Violência da USP, reivindicava mais transparência na Segurança Pública em São Paulo, apontando a pouca credibilidade dos registros das mortes causadas por policiais. Segundo o pesquisador, os números de 2006, divulgados pela Secretaria de Segurança Pública, não incluíam as mortes registradas como "resistência seguida de morte", ocorridas quando os policiais estavam em folga, tampouco o número de pessoas mortas por policiais, em serviço e em folga, em casos registrados como "homicídio doloso" ou "homicídio culposo". Essa falha no registro teria resultado numa distorção dos dados de 2006.

Khan, também cientista político, coordenador de Análise de Planejamento da Secretaria da Segurança Pública do Estado de São Paulo, alega em sua resposta que a letalidade da ação policial em São Paulo aumentou em 2006 em função do cenário detonado pelos ataques do PCC e que a imprensa selecionou, sem nenhuma orientação da Secretaria, os dados divulgados, privilegiando as ocorrências de resistência seguida de morte em serviço.

Para além da denúncia, a disputa conceitual e institucional em torno das estatísticas criminais reforça a importância e a já apontada fragilidade da informação nesse campo e mostra também como, no quadro das mortes em São Paulo, a letalidade da atividade policial ocupa um papel essencial.
} 
De todo modo, como está amplamente documentado pela literatura nacional ${ }^{246}$, historicamente e até os dias atuais, a polícia no Brasil é responsável por abusos de poder, graves violações de direito, corrupção, altas doses de violência. Esse quadro torna-se ainda mais complexo uma vez que tais práticas estão associadas à impunidade difundida dos policiais.

A preferência da polícia pelas vítimas selecionadas entre a população de baixa renda é mais um traço da distribuição desigual da justiça e da violência no país, ajudando a compor, o fluxo ininterrupto de violências e violações ao qual essa população está sujeita.

Com efeito, além da ilegalidade das ações e da própria vitimização violenta de uma parte da população brasileira, do ponto de vista da gestão, ter uma parcela da polícia que é violenta e corrompida é mais um elemento que soma-se ao já grande conjunto de desafios concretos da Segurança Pública no Brasil.

Para Tereza Caldeira, o fato de que "a questão social continua sendo uma questão de polícia ${ }^{247 ",}$, convertendo as classes mais pobres em alvos preferenciais dos abusos, provoca nessa parcela da população desconfiança em relação à justiça e medo da polícia.

Caldeira aponta também os paradoxos que se estabelecem quando as relações entre a polícia e essa população são travadas nesses termos. Nas palavras da antropóloga, "a persistência da violência policial e seu crescimento recente foi possível pelo menos em parte por causa do apoio popular. Paradoxalmente, mesmo as camadas trabalhadoras, que são as principais vítimas dessa violência, apóiam algumas de suas formas ${ }^{248, "}$.

Mas não se trata apenas de aprovar ou tolerar as práticas policiais. Como observam ScheperHuges e Bourgois ${ }^{249}$, em alguns casos a violência interpessoal mimetiza a repressão praticada pelo Estado, podendo ser operada em doses maciças e com excesso de crueldade. Como vimos por meio de alguns exemplos trazidos nesse trabalho, o autoritarismo, a sumariedade e, em muitos casos, também a crueldade, podem ser apontados como características da violência regularmente praticada.

Cria-se assim um padrão segundo o qual, não se está mais falando apenas em medo ou temor da polícia, mas também num conjunto de expectativas que se estabelece pautado nesse tipo de atuação. Vimos, por exemplo, o pouco crédito dado por Marcelo as possíveis soluções

\footnotetext{
${ }^{246}$ Caldeira, 2000; Bretas, Poncioni, 1999; Cardia, 1997; Kant de Lima, 1989, 1995; Lemgruber, Musumeci, Cano, 2003; Mesquita Neto, 1999; Pinheiro, 1982; Soares, 2000.

247 2000: 136.

${ }^{248}$ Idem: 136.

249 2004:19.
} 
legais para seu algoz e como para ele eram legítimas as mortes praticadas pela polícia quando se tratavam de criminosos.

O fato é que a polícia, na condição de braço do Estado responsável pela segurança, por meio ou mesmo além das suas práticas cotidianas, ajuda a construir uma determinada idéia de segurança e justiça - englobando tudo o que está associado à elas - como instituições a serviço da repressão ou da contenção, da vitimização dos pobres, mas jamais como um direito, sua condição original.

As raízes dessa distorção são muitas. É claro que o modo como a segurança vem sendo tratada enquanto tema e praticada como política tem uma relação de causa e efeito com a maneira pela qual é lida. Mas os limites estabelecidos a partir da definição de quem está querendo proteger quem e do que acabam também se tornando referências importantes.

Num artigo elaborado a partir da pesquisa realizada pelo Núcleo de Estudos da Violência da Universidade de São Paulo, "Construção das Políticas de Segurança Pública e o Sentido da Punição, São Paulo (1822-2000)", Marcos Alvarez, Fernando Salla e Luiz Antonio de Souza ${ }^{250}$, enfocam o tema da segurança pública em busca dos elementos que fundamentam as práticas das instituições de justiça criminal no país, durante o referido período, e suas implicações para o Estado de Direito democrático brasileiro.

A reflexão proposta toma como ponto de partida a produção acadêmica sobre o assunto, combinada com o tratamento que o tema da segurança recebeu enquanto objeto de formulação de políticas públicas. São consideradas as peculiaridades das políticas de segurança no que se refere aos processos decisórios associados a elas e à sua implementação, considerando os diversos arranjos institucionais ao longo da história brasileira.

O descompasso apontado pelos autores entre os processos de modernização política, econômica e social, e a concretização das garantias legais e os direitos civis, permite que observemos a "persistência das graves violações de direitos humanos no país, pensada como elemento constitutivo da nossa formação política e da reprodução de uma sociedade profundamente hierarquizada ${ }^{251}$.", responsável pela fragilidade democrática e a consolidação parcial da cidadania no Brasil.

É interessante a maneira como os autores assinalam a importância dos direitos humanos nessa reflexão. Ao mesmo tempo em que são um tema quase que onipresente na produção acadêmica que trata do tema da segurança pública desde o início dos anos 1980, os direitos

\footnotetext{
2502004.

${ }^{251}$ Alvarez, Salla e Souza, idem: 13.
} 
humanos são também a referência para as avaliações do impacto das políticas nessa área adotadas desde esse período ${ }^{252}$.

Com isso em mente e diante das graves violações desse conjunto de direitos praticadas a despeito da retomada democrática no país, é preciso assumir que a não garantia dos direitos humanos ou as suas violações constantes são dados constituintes da própria história dos direitos no Brasil, com consequiências imediatas para a seleção dos termos nos quais as políticas de segurança foram formuladas e implementadas no país.

Ainda no churrasco do time de futebol relatado no capítulo 2, quando descobri que era possível engravidar pela mão, fui interrogada por um outro grupo de pessoas sobre qual era a razão da minha presença constante no bairro. "Sou amiga do Marcelo e venho visitá-lo de vez em quando" foi minha resposta. "Ela está construindo uma biblioteca no bairro" acrescentou Francisco, que estava ao meu lado, aparentemente querendo dar mais legitimidade à minha presença no local. "Mas a gente te vê sempre aqui, você trabalha com o que?" A conversa (ou o interrogatório) continuava. "Trabalho com pesquisa e também trabalho com políticas na área da segurança pública", respondi.

Seguiu-se um silêncio. Eu não sabia como continuar a conversa e meus interlocutores, aparentemente, também não. 0 silêncio que persistia, somado ao visível constrangimento de Francisco, me deram a exata dimensão da minha infeliz escolha de palavras. "Ela é gente boa" Francisco sentenciou, puxando-me pelo braço e levando-me para outra roda de pessoas. O episódio, para além de uma conversa atrapalhada, foi capaz de explicitar de que maneira a segurança é entendida pelos moradores do bairro uma vez que ela se conforma como uma realidade distante e é constantemente praticada contra eles. Não pude saber o que exatamente se passou pela cabeça das pessoas com quem conversava, mas falando com Francisco mais tarde e procurando entender o silêncio e o fim abrupto da conversa, ele me disse: "do jeito que você falou, parece que você trabalha com a polícia ou está aqui para achar bandidos".

No meu entendimento, nada do que eu havia dito carregava esse tipo de sentido. Mas, além de agregar (mais) um divisor em nossos universos, o episódio evidenciou que a segurança, ainda que seja um direito fundamental, não é "coisa para os pobres". Meus interlocutores daquele momento aprenderam por experiências próprias ou de terceiros que esse não era um tema para eles.

${ }^{252}$ Ibidem: 7. 
Luis Eduardo Soares foi pioneiro no diagnóstico a respeito dos impasses enfrentados pela Segurança Pública no Brasil. Ao rever sua trajetória como Subsecretario na Secretaria de Segurança Pública do Rio de Janeiro ${ }^{253}$, o antropólogo e cientista político que foi Secretário Nacional de Segurança Pública em 2003 e atualmente é Secretário Municipal de Valorização da Vida e prevenção da violência, em Nova Iguaçu, no Rio de Janeiro, fez uma revisão sobre os entraves ao avanço das políticas nessa área, revelando uma complexidade assentada em muitas camadas: institucionais, políticas e culturais. A curta, mas intensa trajetória de Luiz Eduardo Soares e sua equipe no governo do Rio de Janeiro explicitou que os desafios estão colocados para a dimensão técnica e executiva das políticas de segurança, do mesmo modo em que se encontram também ao campo conceitual. Não por acaso, Sergio Adorno empresta do antropólogo Victor Turner a expressão “drama social” para definir, de maneira inspirada, a experiência de Soares, ressaltando a sua multiplicidade ${ }^{254}$.

Ainda que, como vimos, no Brasil o crescimento mais dramático da criminalidade urbana seja um fenômeno datado do início dos anos 80 , foi só no princípio da década de 90 que o tema da segurança pública ganhou contornos mais definidos.

Nesse cenário, Soares identifica entre as esquerdas brasileiras uma dificuldade em dissociar segurança de repressão, fazendo deste um tema naturalmente "conservador", que remete quase que de maneira imediata aos modelos ainda relativamente frescos da ditadura militar. Logo, esse continuava sendo considerado um assunto da "direita", o que fez com que, conseqüentemente, segundo o autor, a esquerda nunca apresentasse um debate amadurecido ou um plano mais objetivo concernente à segurança no Brasil.

Paralelamente, a criminalidade urbana foi entendida durante muito tempo como mais um dos problemas de ordem estrutural do país ${ }^{255}$. Em outras palavras, para vencer a violência nos grandes centros urbanos seria preciso corrigir as distorções e desigualdades sociais do país: acabar com a fome, garantir o acesso à educação e à saúde, etc. Assim, acabar com a

${ }^{253}$ Soares, 2000.

${ }^{254}$ Adorno, 2002b.

${ }^{255}$ Alba Zaluar (1999), argumenta que os estudos que privilegiaram a perspectiva estrutural - traduzida, por exemplo, em idéias como estrutura social desigual, luta de classes, exclusão social - para debater os temas referidos, tornaram-se predominante nos anos 70. Como explica a autora, neste caminho analítico "a violência estrutural passa a ser distinguida das outras manifestações de violência: a institucional, a doméstica, a interpessoal" (idem: 35). Zaluar chama a atenção para o fato de que nesta leitura a violência torna-se sinônimo de desigualdade, exploração, dominação, exclusão, segregação e outros elementos associados à pobreza ou a formas de descriminação pela cor e de gênero. Sob essa ótica, não estariam disponíveis ferramentas que permitissem a análise de expressões sociais de violência caracterizadas pelo uso em excesso ou descontrolado da força física e dos meios de controle social. 
violência no país era entendido necessariamente como um projeto de longo prazo, que dependeria quase de uma revolução social ${ }^{256}$.

Num texto mais recente ${ }^{257}$, o autor sustenta inclusive que a distinção entre tais níveis de intervenção não é relevante já que ambos são importantes, necessários e contribuem para prevenir a criminalidade. E, com efeito, não devem ser tomados como modelos a serem escolhidos com exclusividade.

A coincidência entre o crescimento da criminalidade com o período de redemocratização do país fez deste um quadro ainda mais complexo. A sucessão de governos democráticos, a difusão do tema entre acadêmicos que se especializaram no assunto e a sociedade civil que lentamente se organizou nos últimos 10 anos, acabaram por construir conjuntamente uma nova concepção de segurança pública no país. Mas esse é ainda um debate recente e frágil ${ }^{258}$. Também por essas razões, a segurança não foi nunca, até muito recentemente, discutida como um conceito ou um instrumento político a serviço da igualdade social ou da democracia.

O paradigma penal clássico segundo o qual a intimidação proveniente da possibilidade de punição seria a essência da idéia de segurança, inspira até hoje as práticas e interpretações nesse campo, dificultando a dissociação tão fundamental entre segurança e repressão.

Segurança como um "assunto de polícia” é uma representação que perdurou por muitos anos e hoje, lentamente, passa por uma transformação quando observamos a ampliação da arena de atores envolvidos com o tema e com a formulação de políticas nessa área. Para além de objeto da atuação policial, segurança é hoje um tema que vagarosamente vai encontrando e estabelecendo interfaces com outras áreas tais como educação, saúde e mesmo planejamento urbano.

Atualmente, a abordagem exclusivamente macro da segurança co-existe com a valorização das ações locais, privilegiando seu potencial preventivo. Mas da mesma maneira como o debate conceitual, esse é um processo que se consolida lentamente e o Brasil ainda tem poucas experiências bem sucedidas inspiradas por esse novo paradigma ${ }^{259}$.

\footnotetext{
${ }^{256}$ Cf. Soares, 2000.

257 Soares, 2006.

${ }^{258}$ Um histórico minucioso desse processo e dos marcos legais que o acompanharam, assim como o mapeamento desses atores, pode ser encontrado em Muniz e Zacchi, 2005.

${ }^{259}$ Seguindo uma tendência mundial, a partir de 2001 os municípios no Brasil passaram gradualmente a assumir um papel de maior protagonismo no panorama da segurança local. As experiências locais têm como partido fundamental a ênfase no caráter preventivo da segurança. O município paulista de Diadema vem desde 2001 desenvolvendo uma série de ações, sintetizadas nos dois planos municipais de segurança, que contribuíram de maneira determinante para a redução dos homicídios na região. As ações são de natureza variada e compreendem, entre outras coisas, a campanha pelo desarmamento da população, a valorização da Guarda Municipal, a instalação de núcleos de mediação de conflito em áreas vulneráveis do município e o controle da venda de bebida alcoólica a partir das $23 \mathrm{~h}$. Os municípios de Recife, de
} 
A ausência de um projeto alternativo relativo à segurança contribui para a dificuldade de formulá-la (a segurança) em outros termos; seja para os formuladores das políticas, seja para os beneficiárioslusuários dessas políticas; seja para o próprio debate público ou o senso comum.

Parte desse descompasso explica-se pela inclusão tardia do tema da Segurança Pública e da própria política de Segurança Pública no que se refere a seu aparato funcional e estrutural no debate sobre a democratização do país. O advento da "Constituição Cidadã", de 1988, foi capaz de detonar um processo de mudanças substantivas em muitos campos das políticas públicas, sobretudo aquelas voltadas as áreas sociais e de promoção de direitos. 0 mesmo, no entanto, não ocorreu no campo da Segurança. Tudo isso se explica, ao menos em grande parte, porque as instituições e o aparato disponível - as forças policiais, as responsabilidades de cada ente federado, o sistema de justiça criminal, entre outras - passaram por reformulações ou mudanças mínimas, incapazes de promover as transformações necessárias ${ }^{260}$.

Não obstante, para além da sua dimensão prática, quais seriam as barreiras para que, no campo conceitual, a segurança seja formulada como um direito?

Ao longo dos capítulos anteriores vimos como a violência, além de se manifestar de formas diversas e afetar grupos - mulheres, crianças e jovens - de maneiras distintas, é também capaz de acentuar disparidades. 0 grau e o modo como a segurança é praticada também explicita e acentua disparidades.

Entender como a segurança se constitui enquanto tema, é praticada como política, assim como ela é distribuída socialmente, é parte da tarefa compreendida no diagnóstico de processos de construção de uma sociabilidade violenta.

As políticas de segurança são claramente uma maneira de responder à violência e à criminalidade. Ao mesmo tempo, são capazes de retratar a maneira pela qual a violência é percebida e absorvida pela sociedade em seus diversos segmentos.

Olinda e de Camaragibe, no Estado de Pernambuco integram o projeto de "Novos Consórcios Públicos para Governança Metropolitana e Prevenção à Violência Urbana" em curso atualmente, cujo objetivo é desenvolver planos locais e compartilhados de prevenção. Finalmente, vale ainda citar o exemplo do Programa "Fortaleza da Paz", também um programa de políticas locais de segurança, lideradas pela Prefeitura de Fortaleza, cuja previsão de lançamento é fevereiro de 2009.

Para uma discussão mais detalhada sobre o papel dos municípios na segurança pública, Cf. Miraglia, 2006; Mesquita Neto, 2006; Caruso e Ricardo, 2007.

${ }^{260}$ Muniz e Zacchi, op. cit. 


\section{I.As sombras entre o legal e ilegal}

O descrédito das instituições de segurança, combinado com a sua real incapacidade para lidar com o problema da criminalidade urbana ao longo dos quase últimos 30 anos, são ilustrados pela já referida pouca confiabilidade depositada na polícia pela população, assim como é expresso pelas altas taxas de criminalidade urbana que parecem impossíveis de serem contornadas. Uma de suas conseqüências é a promoção de práticas alternativas de manutenção da ordem.

Essa, no entanto, não é uma equação simples ou imediata. Como veremos a seguir, as modalidades paralelas de contenção ou de imposição da ordem, combinam de maneira complexa e enviesada o que está disponível para cada classe social, anunciando os limites da capacidade e mesmo da vontade do Estado, além de expor as encruzilhadas do aparato democrático quando submetido a um território nebuloso, onde os espaços do legal e do ilegal não necessariamente encontram-se em oposição.

O exercício privado da vigilância e da segurança não é novidade e pode ser encontrado em diferentes versões ao longo da história da humanidade. Sua oposição ao caráter público desses serviços, todavia, vem ganhando novos significados em função dos cenários ditados pela criminalidade urbana atual e da própria resposta do Estado diante dessa realidade.

Um retrato da paisagem de São Paulo já deixa notar novos adereços adquiridos nos anos recentes: as guaritas e os seguranças de ternos, sentados de baixo de um guarda sol, onde se vê o nome de uma empresa de segurança privada. Esses são elementos quase que obrigatórios das fachadas dos edifícios nos bairros ricos e de classe média de São Paulo - os enclaves fortificados ${ }^{261}$. Completam a paisagem os carros blindados, as casas e edifício murados, os carros guiados por seguranças que seguem outros veículos a título de proteção. De acordo com dados do último relatório do UN-Habitat (programa de assentamentos urbanos das Nações Unidas) pelo menos 25.000 residências particulares, na cidade de São Paulo, são monitoradas por câmeras de vigilância. O mesmo relatório aponta que depois dos ataques do PCC, houve um aumento de $33 \%$ nas vendas de vidros blindados para automóveis ${ }^{262}$.

No Brasil a segurança privada tem sua origem ainda no Governo Militar ${ }^{263}$. Mas acompanhando o crescimento da criminalidade no país, esse é um mercado que está em franca expansão. $\mathrm{Na}$

\footnotetext{
${ }^{261}$ Caldeira, 2000.

${ }^{262}$ UN-Habitat, 2007: 14.

${ }^{263}$ Caldeira, op. cit.
} 
sua forma empresarial, trata-se de um fenômeno mundial e assim como o crescimento da violência, está associado aos processos de urbanização das grandes cidades.

No Brasil chama a atenção de maneira particular o crescimento de tais serviços. 0 estudo de Leonarda Musumeci mostra, a partir dos dados da PNAD, que entre 1985 e 1995, o número de profissionais ocupados na atividade de vigilância e guarda cresceu $112 \%{ }^{264}$. Dados de 2006 revelam que o mercado da segurança privada como um todo movimentou a cifra de U\$ 49 bilhões de dólares, o que representa $10 \%$ do Produto Interno Bruto do País ${ }^{265}$.

Na sua dissertação de mestrado defendida no Departamento de Ciência Política da USP, sobre a regulação das empresas de segurança (aspecto pouco tratado pela literatura brasileira sobre o assunto), André Zanetic argumenta que a expansão do mercado no Brasil poderia ser explicado por três fatores: “i. O crescimento da criminalidade (sobretudo a especialização do crime); ii. A percepção da violência e o aumento da insegurança; e iii. As mudanças na utilização do espaço urbano e circulação da população nas grandes cidades ${ }^{266}$."

Hoje, as empresas de Segurança Privada, desde que regulamentadas, estão autorizadas a desempenhar atividades em sete campos distintos: vigilância, segurança Orgânica (empresas que fazem a sua própria segurança), segurança patrimonial, segurança pessoal, curso de formação, escolta armada e transporte de valores ${ }^{267}$. Com efeito, "segurança privada" é um nome genérico para definir um conjunto extenso de atividades e serviços, legais ou não. Para o senso comum, significa qualquer tipo de segurança ou de vigilância que não é provida pelo Estado.

Essa confusão ou a pouca clareza entre a diferença e os limites entre a segurança estatal e a privada se explica, entre outros motivos, porque tais serviços reproduzem muitas das práticas do Estado sem que tenham necessariamente esse direito. São assimilados pela sociedade como se fossem forças policiais estatais, o que parece bastante paradoxal. Afinal, se somos uma sociedade que em tese não se submete à lei, dado que seria atestado pelos índices de criminalidade, por que nos submeteríamos tão facilmente à vigias não legítimos? Como aponta Musumeci, as armas, as fardas, o direito adquirido para revistar, vigiar e até mesmo deter, são elementos que contribuem para tal indiscriminação.

Os limites de atuação dos funcionários é matéria controversa. Dois episódios recentes ilustram sua fragilidade. No dia 28 de fevereiro de 2007, em Moema, um bairro de classe média alta

\footnotetext{
${ }^{264}$ Musumeci, 1998.

${ }^{265} \mathrm{UN}-\mathrm{Habitat}$, op.cit.

${ }^{266}$ Zanetic, 2005: 34.

${ }^{267}$ Zanetic, 2005:10.
} 
em São Paulo, o segurança particular de um bingo foi ao banco, que por acaso ficava em frente ao bingo onde trabalhava. Nesse mesmo momento o banco foi assaltado e o segurança decidiu atirar no ladrão com sua própria arma (a qual ele está autorizado e habilitado a utilizar na condição de segurança do bingo exclusivamente). Seus colegas de trabalho, vendo o que acontecia no banco em frente, também atiraram contra os bandidos que responderam também com mais tiros. Um bangue-bangue estava armado sem a presença da polícia, que só chegou ao local quando os assaltantes já haviam fugido e uma menina, que esperava no ponto de ônibus próximo, encontrava-se ferida ${ }^{268}$.

Mais recentemente, no mês de outubro de 2007, em Londrina, um jovem que voltava de um jogo de futebol foi detido pelos vigias de uma empresa particular de segurança, responsável pela vigilância de uma clínica, quando pichava a parede do estabelecimento. 0 jovem foi encontrado morto alguns dias depois e os seguranças, que em princípio confessaram o crime, foram acusados de tê-lo torturado e matado.

Um aspecto grave que caracteriza esses serviços é que eles não estão submetidos aos mesmos mecanismos de controle que as forças policiais estatais ${ }^{269}$. Se, como vimos, o próprio controle da atuação da polícia é delicado e cercado de dificuldades, nesse caso o quadro é ainda mais sério.

Para Angelina Peralva ${ }^{270}$, a privatização profissional da segurança se beneficiou diretamente da ineficiência das instituições originalmente responsáveis por esses serviços, encontrando aí um terreno fértil para crescer. Mas para a autora, o fenômeno é composto e essa seria apenas uma das suas faces. A outra estaria traduzida nos "fenômenos de justiça ilegal" em curso no interior da sociedade civil.

Recorrendo à etnografia de Tereza Caldeira, Peralva sublinha a interface que tais serviços estabelecem com a ilegalidade, na medida em que recrutam ex-justiceiros e mesmo policiais na ativa como funcionários. Esse é um dado mencionado de maneira recorrente quando as empresas de segurança privada estão em debate ${ }^{271}$.

A literatura brasileira aponta como a grande chave explicativa para a emergência e crescimento da segurança privada no Brasil a combinação entre a incapacidade do Estado em prover e garantir a segurança, as estratégias das classes mais ricas para se proteger e se

\footnotetext{
${ }^{268} \mathrm{Na}$ época, ainda havia a suspeita de que o Bingo tinha entre seus funcionários contratados policiais militares e guardas civis.

${ }^{269}$ Musumeci, op. cit.

${ }^{270}$ Peralva, 2000.

${ }^{271}$ Cf. também Caldeira, 2000; Soares, 2006.
} 
possível evitar os pobres, somada ao fim do monopólio da violência por parte do Estado ${ }^{272}$. No entanto, ao estudar a regulação das empresas de segurança, André Zanetic expõe a tensão entre os modelos interpretativos, questionando tal abordagem. 0 autor não concorda com a tese do fim do monopólio da violência ou da fragilidade institucional brasileira. Para ele estaríamos diante de um processo de aumento das formas de controle social de maneira geral e a difusão e capilaridade dos serviços de vigilância seria apenas um dos efeitos desse aumento.

Para sustentar seu argumento, Zanetic mostra como o maior contingente de segurança privada está alocado no universo corporativo e não na proteção do cidadão. 0 crescimento do mercado se deu em função do aumento da demanda das empresas por esse tipo de serviço. Ou seja, estaríamos nos referindo a uma tendência de mercado, menos do que a uma rachadura política e institucional. São os bens materiais ou os negócios e não a cidadania, que estariam abdicando da segurança do Estado para reivindicar a segurança particular.

0 argumento é reforçado pelo fato de que inclusive em países com democracias consolidadas onde a soberania do Estado é a princípio inquestionável, tais como o Canadá ou a França, esse são serviços bastante difundidos ${ }^{273}$.

É, porém, o próprio autor quem vai, posteriormente no mesmo trabalho, apontar uma a uma as fragilidades desse universo: as dificuldades de regulamentação, a existência de empresas clandestinas e as questões técnicas relacionadas ao processo de regularização das atividades dessas empresas. 0 autor reconhece que as limitações no campo da fiscalização impedem, por exemplo, um conhecimento mais minucioso do mercado, dificultando o controle das atividades e evitando o uso indevido das armas de fogo, o emprego de policiais, ou mesmo a garantia de treinamento adequado dos profissionais em atividade. Nesse sentido, podemos dizer que emerge da própria indústria a sua fragilidade ou seu potencial para estar à margem da lei.

O fato é que a capacidade de fiscalização do governo não acompanhou o crescimento desse ramo de atuação e o que deveria ser controlado com rigor é na verdade um espaço nebuloso onde proliferam ilegalidades. Os problemas acentuam-se já que são conhecidos no Brasil os desafios de "fiscalização" em muitos outros campos.

\footnotetext{
${ }^{272}$ Caldeira, op. cit. ; Kowarick, 2002; Peralva, op.cit. .

${ }^{273}$ Segundo o autor, nos Estados Unidos, os guardas particulares são três vezes mais numerosos que os policiais no país e no Canadá são mais que o dobro (Zanetic, 2005: 17).
} 
Temos como resultado a dispersão da legitimidade e do poder de coerção, numa rede onde estão entrelaçados o lícito e o ilícito. A melhor ilustração é que policiais, cujos salários são baixos, tem aí seu segundo emprego ${ }^{274}$.

Zanetic tem uma visão otimista, acredita que a segurança privada pode ser efetivamente regulamentada e fiscalizada e que tem potencial para, como já vem fazendo, cumprir um papel complementar à segurança pública, contribuindo para "funções específicas ${ }^{275}$.

Contudo, numa sociedade desigual como a brasileira, o que tal medida significaria exatamente? Tomando como exemplos os serviços públicos que co-existem na forma de serviços privados como a saúde e a educação, e a disparidade na maneira pela qual eles são usufruídos pela população em termos de qualidade e acesso, fica a impressão de que o mesmo poderia acontecer em se tratando da proteção. Nesse caso, sua privatização somar-se-ia ao conjunto de elementos que já foi capaz de empurrar e represar parte da criminalidade urbana nas periferias da cidade.

É claro que a preocupação com a segurança ultrapassa os muros dos condomínios fechados das elites e ecoa também nas classes mais pobres. Tereza Caldeira ${ }^{276}$ já havia notado que as classes mais pobres também têm seus próprios recursos de proteção - trancas, grades ou alarmes e até mesmo condomínios fechados podem ser encontrados em bairros pobres.

Faz sentido que numa cidade como São Paulo a preocupação com a segurança transborde qualquer barreira de classe social. Seria ingênuo imaginar que os pobres não teriam suas estratégias de proteção e segurança, sobretudo quando eles são as vítimas privilegiadas da criminalidade violenta, além de serem, em larga medida, os mais desamparados dos serviços de proteção providos pelo Estado.

Mas ainda assim, é preciso dar proporção a ambos os fenômenos. Aqui novamente a geografia da criminalidade em São Paulo nos oferece pistas interessantes. Como vimos, os crimes contra a vida, os homicídios, com raras exceções, estão majoritariamente concentrados nas áreas periféricas da cidade. No entanto, essa distribuição dos crimes não encontra correspondência ou proporcionalidade na distribuição dos aparatos de segurança particular.

Além disso, a privatização da segurança na sua forma empresarial não pode ser lida como um fenômeno isolado. Deve ser pensada em conjunto com outras estratégias como, por exemplo, o crescente número de carros blindados, as ruas fechadas, os muros cada vez mais altos, o

\footnotetext{
274 Soares, 2006.

${ }^{275}$ Zanetic, idem: 104.

${ }^{276}$ Calderia, 2000.
} 
esvaziamento dos espaços públicos e de convivência. Temos um conjunto de estratégias privadas de solução para um problema que é público.

Não se trata de apontar a boa subversão do monopólio e a má, mas apenas de dar proporções aos fenômenos como uma estratégia para compreender de que maneira tais práticas contribuem para que a violência misture-se de maneira quase que imperceptível ao cotidiano.

Em se tratando da segurança privada, sua variedade, tamanho e ilegalidade compõem uma equação que questiona de modo eloqüente o modo pelo qual a gestão da segurança está dividida no Brasil. Se por um lado o desenvolvimento desse ramo de atividades não pode ser visto exclusivamente como resultado do aumento da criminalidade no país, por outro, a ilegalidade associada e reproduzida pelas suas atividades permite que seu crescimento possa ser percebido também como uma das causas da difusão da violência e do crime no Brasil. A privatização da segurança, nos termos em que foi apontada aqui, seria mais um componente enredado nos fluxos da violência cotidiana.

Também evocando essa interseção entre o lícito e o ilícito, no Rio de Janeiro um fenômeno recente ganhou status de novo ator no já complexo cenário que envolve a criminalidade urbana naquela cidade.

Definidas como um poder extra-oficial que vem se instalando entre as comunidades de baixa renda no Rio de Janeiro, as Milícias configuram-se como grupos paramilitares híbridos, formados por combinações diversas entre policiais, na ativa ou aposentados (reformados), e outros integrantes de órgãos de segurança, tais como corpo de bombeiros, agentes penitenciários, membros das Forças Armadas e até profissionais de empresas de segurança privada.

As Milícias, entendidas como um fenômeno recente, identificado sobretudo no Rio de Janeiro, vêm se impondo como um poder paralelo, mantenedoras da ordem, dedicadas ao combate ao tráfico nas comunidades onde atuam. Mas seu repertório de atuação não está restrito à esfera da segurança e da ordem comunitária, ele inclui a cobrança de taxa de segurança dos moradores, o controle de outras atividades e serviços prestados mesmo ilegalmente na comunidade, tais como o transporte alternativo (as vans, por exemplo), o "net-cat" (nome dado aos "gatos" para distribuição de TV a cabo ilegal) e o comércio de bujões de gás ${ }^{277}$.

Como consequiência temos arranjos até então impensáveis, tal como grupos de traficantes rivais fazendo acordo com o intuito de proteger a atividade do tráfico da chegada das

${ }^{277}$ Misse, 2007:16. 
milícias $^{278}$. Isso sem esquecer de casos em que o Poder Público se apóia na atuação de uma milícia para garantir a pacificação de um determinado território.

Para Oliveira e Zaverucha ${ }^{279}$, do ponto de vista institucional, as milícias não devem ser pensadas por oposição às polícias, mas em conjunto com elas: “Uma força informal (milícia), composta por agentes do Estado, auxilia uma formal (polícia), e vice-versa. As duas instituições se reforçam e se complementam". Esse imbricamento de poderes legais e ilegais revela em primeiro lugar, a incapacidade do Estado em garantir a ordem, a proteção e, por outro, e talvez mais grave, sua conivência com essa ilegalidade.

Outros trabalhos já mostraram formas de poder local. Em São Paulo, Tiaraju D'andrea ${ }^{280}$ relata como na favela de Paraisópolis um líder comunitário e comerciante local se responsabilizava pela segurança da favela, impedindo que o tráfico de drogas se instalasse ali.

Marcos Alvito ${ }^{281}$, ao relatar as transformações nos tipos de punição e padrões de práticas da violência na favela de Acari no Rio de Janeiro, traça um quadro claro de como os chefes do tráfico local, Tonicão, Parazão, e, posteriormente “ $X$ ” sempre impuseram regras, cada um a sua maneira e estilo, traduzidos, inclusive, pelo modo de punir e matar: picando os corpos, queimando as vítimas em pneus, ou "jogando no saco". A despeito das diferenças, como relata o autor, todos sempre administraram a violência no local.

Mas a peculiaridade nesse caso é que estamos falando de grupos organizados, compostos também por membros das forças de segurança do Estado, com práticas ilegais e extremamente arbitrárias e que tem ingerências em outras esferas da vida social local que não apenas as relacionadas propriamente à segurança.

As Milícias podem ser vistas num primeiro momento como a solução para o enfrentamento do tráfico em áreas tradicionalmente ocupadas, ou como uma forma de reduzir a violência e pacificar uma região onde o Estado não foi capaz de fazê-lo. Mas são, na verdade, a substituição de um poder paralelo por outro, também tirano, num campo social já fragilizado como são as comunidades oprimidas pelo tráfico de drogas.

Como se trata de um fenômeno recente, esse é um objeto ainda pouco investigado pela academia, mas indiscutivelmente reconhecido pelas comunidades dominadas e pela sociedade civil organizada, sobretudo carioca, que trabalha com a temática da segurança pública. Com

\footnotetext{
${ }^{278}$ Idem.

${ }^{279} 2007$.

${ }^{280}$ D'andrea, 2006.

281 Alvito, 1999.
} 
efeito, podemos dizer que as Milícias estão se configurando como um modelo temerário e igualmente perigoso, trazendo consigo um rearranjo inédito de uma combinação antiga, onde o Estado se mistura ao crime, criando mais uma sombra que esmorece as fronteiras entre o legal e o ilegal.

Mas esse amálgama entre o público e o privado não é um fenômeno local e tampouco um privilégio brasileiro. Saltando do Rio de Janeiro para contextos transnacionais, veremos que o tema da segurança na condição de serviço, bem como sua administração, merecem também considerações mais amplas.

Em Corporate Warriors ${ }^{282}$, Paul W. Singer apresenta o resultado de uma extensa pesquisa sobre um tema até então não investigado de maneira sistemática: as Firmas Militares privadas - Privatized Military Firms (PMFs).

Assumindo versões diversas, as PMFs estão espalhadas ao redor do mundo. Sendo sua contratação uma prática difundida, não apenas entre Estado fracos ou países remotos, mas também entre Estados fortes, com aparente governabilidade sobre seus conflitos e plena capacidade para resolvê-los com recursos nacionais, tais como os Estados Unidos ou determinados países europeus.

Por um lado, talvez tal fato se explique pela diversidade de atividades para as quais as PMFs podem ser contratadas: se for preciso elas fornecem o exército, isto é, o contingente humano necessário para uma guerra, ou as armas e outros equipamentos tais como helicópteros, aviões, etc. Elas ainda podem treinar exércitos nacionais, desenhar planos de ataque ou elaborar logísticas para exércitos já treinados. As PMFs podem ainda trabalhar na reconstrução de países destruídos por uma guerra; uma atividade reconhecidamente lucrativa. A natureza do trabalho depende da demanda do cliente.

Reside nessa relação mercantil um dos argumentos fundamentais do livro. Estamos falando de um serviço, como muitos outros (saúde e educação poderiam ser exemplos), prestado por uma indústria, que gera lucros imensos.

Diante desse cenário e com esse tipo de forças militares, seria preciso rever o que está em jogo numa guerra. A escolha de um "lado", por exemplo, torna-se bastante relativa ou até mesmo insignificante na medida em que estamos falando da contratação de serviços.

\footnotetext{
${ }^{282}$ Singer, 2003. Hoje já há uma literatura considerável sobre o assunto. Alguns exemplos são os recémlançados: Blackwater: The Rise of the World's Most Powerful Mercenary Army (Scahill, Jeremy, 2007) e Corporate Soldiers and International Security: The Rise of Private Military Companies (Kinsey, Christop, 2007). Singer, além de ser o precursor dos estudos nesse área, foi o primeiro também a fazer uma pesquisa em profundidade sobre $\mathrm{o}$ assunto.
} 
Refazendo a história recente das PMFs, Singer aponta como elas foram fundamentais na resolução de grandes guerras e conflitos contemporâneos na África, América Central e Leste Europeu. Esses eram conflitos entre Estados, ou intra-estados que foram resolvidos com recursos nacionais ou, no máximo, com apoio de outros países, no caso de guerras civis. 0 autor deixa claro que ao longo da história da humanidade, esse tipo de prática, ainda que em outro formato, sempre existiu. O Império Romano, a Guerra dos 100 anos, a Guerra dos 30 anos, são alguns dos exemplos citados. A própria figura do mercenário é tratada pelo autor que faz alguns paralelos possíveis com as motivações privadas para a guerra nos dias atuais.

Singer, aponta, contudo, diferenças fundamentais entre mercenários e a indústria no mundo globalizado, seja no que se refere ao seu impacto, seja na estrutura de corporação voltada unicamente para o lucro ou a diferença entre o caráter individual e o corporativo que distingue as duas atividades.

Sem ignorar tendências mundiais de privatização em campos diversos, Singer mostra como há um paralelo entre o processo de privatização das forças militares e a concorrência de determinados eventos históricos. Bons exemplos são o fim da Guerra Fria, ou as conseqüências da fraca liderança das Nações Unidas no cenário internacional em momentos importantes. Faz ainda um relato minucioso do funcionamento das PMFs, dos tipos de operações possíveis, descrevendo desse modo o próprio mercado existente e a demanda crescente por esse tipo de serviço.

Ainda que a referência no caso dos exércitos privados seja o cenário global e os conflitos militares tenham uma natureza distinta da criminalidade urbana, alguns paralelos são possíveis e proveitosos para pensar as questões abordadas nessa tese: assim como no caso das indústrias de segurança privada, há uma diversidade grande na prestação de serviços e nos perfis das PMFs ao redor do mundo; da mesma maneira, há um vasto terreno frágil das delimitações entre o legal e ilegal que cercam suas atividades.

Entre as Milícias, as empresas de segurança privada e as PMF's temos um gradiente que vai do local ao global, retratando de espaços alternativos de controle social que, quando combinados com um descrédito e incapacidade do Estado, são capazes de criar modelos híbridos onde as esferas do legal e do ilegal não se encontram mais em oposição, mas parecem se complementar num ciclo de reprodução de ilegalidades.

A comparação permite colocar lado a lado democracias com níveis de eficácia distintos do ponto de vista da garantia dos direitos, ao mesmo tempo em que proporciona uma reflexão acerca do controle e da ordem social, em se tratando de modalidades diferentes de conflitos. 
Se em todos os casos encontramos "brechas" para atuação da segurança privada, para a existência de PMFs, ou mesmo para formação de Milícias, temos que questionar a capacidade do Estado em administrar sozinho os seus conflitos. O problema, contudo, parece ser menos 0 fato de que o controle social é exercido por outros agentes que não os estatais, mas a forma como tal modalidade de serviços vem sendo realizada de modo a valorizar a esfera privada de (falsas) soluções.

Podemos dizer, portanto, que não apenas a violência por si só deve ser tratada como um produto e produtor das desigualdades. A administração da segurança com finalidades distintas, como pudemos acompanhar, também impõe mudanças nas formas de organização social que acentuam ainda mais essa desigualdade.

\section{Violência e instituições}

Durante todo o trabalho viemos reunindo elementos que ao mesmo tempo em que evidenciam as dimensões contextuais ou circunstanciais da violência, são capazes de indicar uma eventual origem estrutural do fenômeno. Como resultado dessa tensão identificamos um cotidiano que é vítima dessa violência, mas, que ao longo do tempo, também aprendeu a absorvê-la.

Nesse processo temos, entre outros efeitos, a multiplicação de atores capazes de participar de maneira ativa, com instrumentos de coerção, nessa arena das conflitualidades.

Indagando de que modo a organização da sociedade sob a forma de "Estados" e seu monopólio da força física estão relacionados com a "civilização", Norbert Elias ${ }^{283}$ argumenta que "a estabilidade peculiar do aparato de autocontrole mental que emerge como traço decisivo, embutido nos hábitos de todo ser humano 'civilizado', mantém a relação mais estreita possível com a monopolização da força física e a crescente estabilidade dos órgãos centrais da sociedade ${ }^{284 "}$. O padrão altamente regulado de autocontrole advindo daí, seria, para o autor, uma espécie de "segunda natureza" dos indivíduos.

A definição Weberiana clássica determina que aquilo que define o Estado Moderno é o fato de que este é detentor do monopólio do uso legítimo da violência física. Concretizar tal tarefa por meio da coação física é o meio específico que caracteriza o Estado. Segundo Max Weber, praticar o monopólio da violência através da coerção garante que o conjunto de indivíduos abra mão da liberdade, não espontaneamente, mas como efeito da coerção. Apenas dessa

\footnotetext{
${ }^{283} 1939[1993]$.

${ }^{284}$ Idem: 197.
} 
maneira, todos estariam sujeitos à mesma justiça e normas ${ }^{285}$. Nesse sentido, o Estado tem não só o monopólio legítimo do uso da violência, mas também o poder e o dever de proteger seus cidadãos.

O monopólio da violência por parte do Estado é, portanto, uma das bases do contrato social, na medida em que o Estado sintetiza a possibilidade de controlar o comportamento transgressor com a pratica da punição.

Nesse mesmo sentido, o próprio Elias também vê no monopólio da força a condição capaz de criar espaços sociais pacificados, que não estão sujeitos à violência ${ }^{286}$.

Cotejando as tradições kantianas e weberianas no debate acerca da constituição do Estado Moderno, Sergio Adorno mostra como se estabeleceu a identidade entre Estado, poder e lei. 0 autor reconhece o "[...] esforço kantiano de demonstrar que o oposto da violência - em particular daquela que envolve a imposição da vontade de uns sobre outros em um contexto pré-estatal - não é a ausência de violência, porém o direito ${ }^{287}$ ". Ao fazer isso problematiza os limites da atuação do Estado quando ela pressupõe o uso da violência.

Um dos aspectos importantes na formulação weberiana reside na reconhecida legitimidade da força empreendida por parte do Estado. Soma-se a isso o fato de que ela é limitada. A combinação entre esses dois dados faz com que a legitimidade do uso da força na sociedade moderna esteja fundamentada na sua correspondência com a lei.

Esse é um debate clássico das Ciências Sociais, contemplado por uma ampla bibliografia. Nessa tese, no entanto, não nos interessa avaliar o quanto a soberania do Estado, nos moldes weberianos e na condição de pressuposto capaz de pacificar uma sociedade, está sendo minada pelas transformações sociais implicadas nos múltiplos fenômenos como a globalização, o avanço do consumismo, o enfraquecimento dos laços sociais, etc. A preocupação desse trabalho trata de apreender como as distorções desse modelo, a partir de práticas relacionadas a temas fundamentais ao modelo original, tais como repressão e contenção, vêm sendo perpetradas. Seja do próprio Estado, por meio da justiça criminal, seja pela privatização da segurança, seja pela privatização da resolução de conflitos. Em todos esses contextos, tais transfigurações têm se mostrado capazes de produzir novos referenciais e novas práticas sobre a idéia de controle, punição e pacificação social.

\footnotetext{
${ }^{285}$ Weber, 1983.

${ }^{286}$ Elias, idem: 198.

${ }^{287}$ Adorno, 2002b: 8.
} 
Ao longo do último século, as sempre complexas relações entre cidadãos, Estados, assim como a própria idéia de paz e segurança ganharam novas configurações. O Estado ainda mantém o status de ator principal na garantia da paz, mas a segurança dos Estados não pode mais ser compreendida como a garantia da segurança de seus cidadãos. Tal fato fica claro tanto porque estamos falando em níveis distintos de segurança e manutenção da paz, como porque em muitos casos, como vimos no exemplo brasileiro, o próprio Estado atua como um dos violadores da segurança dos cidadãos. Além do mais, muitas vezes o próprio Estado compete com a administração privada da segurança - de maneira organizada (no caso das empresas ou das milícias, ou do crime organizado) ou informal (no caso da justiça feita pelas próprias mãos por parte de indivíduos).

Mas se há um consenso de que o Estado perdeu, pelo menos relativamente, o monopólio da prática da violência, sabemos que o fim do monopólio não implica o fim da própria violência ou da força coercitiva. Ao contrário, nesse contexto é preciso pensar de que maneira e por meio de quais mecanismos ela é redistribuída entre os diversos atores sociais.

A gestão privada da segurança e da punição configura-se como mais uma arena onde estão manifestas "formas não estatais de governabilidade social ${ }^{288 "}$. Há uma relação que se dá em muitos níveis entre a desqualificação do Estado e da sua exclusividade e as interações de tipo violento entre os atores sociais.

Para Caldeira, o Brasil viveu o "monopólio progressivo do uso da força pelo Estado", mas os abusos praticados pelas forças policias que sempre fizeram uso da violência e se importavam pouco com o respeito à cidadania enfraqueceram a capacidade e a legitimidade das instituições públicas para que essas atuem como mediadoras dos conflito. Afinal, elas mesmas fazem parte do ciclo de vingança ilegal e privada e, "ao entrarem num ciclo da vingança em vez de agirem contra ela, as instituições da ordem apenas contribuem para o aumento da violência e para sua própria deslegitimação ${ }^{289}$."

Nesse sentido, o Estado brasileiro não estaria habilitado a ser o mediador legítimo do elevado número de conflitos do tipo que encontramos no Parque Novo Santo Amaro. Os homicídios que, como vimos podem ser classificados como "violência comunitária", "violência interpessoal", ou ainda "violência institucional" quando são praticados de maneira ilegítima por agentes do Estado, seriam, portanto, resultado dessa dupla distorção: a privatização das resoluções de conflito e um Estado inabilitado e sem legitimidade para mediar conflitos nos limites da legalidade.

\footnotetext{
${ }^{288}$ Moser, 2004.

${ }^{289}$ Caldeira, 2000: 136.
} 
Segundo Lima, "os conflitos sociais engendrados na realidade brasileira são resolvidos à base de níveis elevados de violência, em que o processo civilizatório não formou instituições públicas capazes de garantir o monopólio legítimo da violência e a pacificação social, nos termos de Weber e Elias" 290 . Em seu trabalho sobre o lugar dos homicídios na criminalidade urbana, Lima faz uma longa revisão de uma bibliografia multidisciplinar - produzida por sociólogos, urbanistas, antropólogos - elaborando uma análise que combina resultantes históricas, "disjunções democráticas"291 e padrões de exclusão urbana (agregando indicadores de emprego, educação, moradia, renda, etc.). Ainda segundo o autor, algumas análises mostram como nas sociedades onde há uma fragilidade do Estado no que se refere ao monopólio da violência, há por oposição, um fortalecimento de laços locais o que por sua vez diminuiria a "pressão social para o controle das emoções e da violência física, resultando em baixos sentimentos de culpa quanto ao uso aberto da violência nos conflitos”292. Seria esse o caso dos bairros pobres de São Paulo, com altas taxas de homicídio, onde segundo o autor: “'[...] a exacerbação dos localismos... pode estar ajudando a criar condições para o retrocesso da civilidade" 293 .

Há uma série de autores que escolhe esse caminho interpretativo e enxerga a resolução violenta de conflitos com uma desqualificação das instituições normativas, um efeito de uma cidadania que não se realiza, de um modelo democrático cercado de falhas, desigualdades e privilégios.

Para Gilberto Velho, o contexto brasileiro, "trata-se claramente, de uma situação em que a cidadania não se impôs como valor nem implementou mecanismos democráticos que possibilitassem o desenvolvimento de um sistema sóciopolítico minimamente satisfatório para a maior parte da população do país ${ }^{294 ”}$. Em outras palavras, não temos cidadãos interagindo em igualdade num espaço regulamentado por leis às quais todos estão sujeitos de maneira igualitária.

José Vicente Tavares dos Santos também vê um processo de crise nessas instituições. Para o autor, a "violência difusa" nas sociedades contemporâneas, que pode se manifestar como violência ecológica, exclusão social, violência entre gêneros, racismos ou violência na escola, expressa um processo de dilaceramento da cidadania ${ }^{295}$. Para Tavares dos Santos ${ }^{296}$, nesse

290 2002: 82.

${ }^{291}$ Caldeira, Holston: 1999.

${ }^{292}$ Lima, op. cit.: 89, apud Zaluar: 1998.

${ }^{293}$ Lima, idem.

${ }^{294}$ Velho, 2000:15.

295 1999, 2004.

2961999. 
contexto, a violência poderia ser entendida como a própria forma de sociabilidade; uma verdadeira norma social que ganha status de mecanismo de controle. Além do mais, faz com que a interação social passe a ser marcada por estilos violentos de sociabilidade, "invertendo as expectativas do processo civilizatório ${ }^{297 "}$.

Tereza Cadeira descreve a experiência política brasileira a partir do caráter disjuntivo da sua democracia. Para a autora, no Brasil há democracia política e os direitos sociais estão razoavelmente assegurados, mas os direitos civis, assim como a cidadania, ainda são frágeis e nem sempre reconhecidos ${ }^{298}$.

Paulo Sérgio Pinheiro faz coro com a leitura de Caldeira e também enxerga no Brasil uma democracia sem cidadania. 0 autor chega a reconhecer a continuidade autoritária no país, expressa, sobretudo, na forma de atuação das instituições de administração da justiça ${ }^{299}$.

Angelina Peralva ressalta que a experiência democrática é caracterizada essencialmente pela capacidade dos indivíduos de se considerarem iguais uns aos outros ${ }^{300}$. A lei trataria de preencher as lacunas deixadas pela desigualdade. Mas seria esse um projeto viável num contexto de desigualdades sociais tal como o brasileiro?

A violência no grau em que é vivida hoje no Brasil, da maneira como vem sendo descrita nessa tese, testa os limites do discurso democrático. Em se tratando de conflitos, diante da realidade das interações entre os diversos atores sociais ou os grupos, percebemos que estas pressupõem um suporte democrático - um aparato que seja capaz de conter as paixões e os impulsos, mas também lembrar a existência da regra - que nem sempre está disponível ou pode ser acessada.

Do ponto de vista estrutural estão sendo criados contextos onde se perde a clareza dos limites da regra. Essa é a mensagem proferida pelo Estado quando um policial comete um abuso ao exercer seu trabalho impunemente ou emprega-se numa empresa de segurança privada. Ou ainda quando o Estado mata 109 "suspeitos" como ocorreu nas retaliações ao PCC, ou tolera a existência e até faz parte da composição das milícias armadas.

Mas é preciso notar que essa também é a mensagem reproduzida quando um número alarmante de jovens são mortos por outros jovens nas periferias da cidade. Não se trata de equiparar os conteúdos, mas de apontar que se a violência é também uma forma de comunicação, ao circular dessa maneira, com tamanha contundência (manifesta nas mortes e

${ }^{297}$ Tavares dos Santos, 2004: 3 .

298 2000: 343.

${ }^{299}$ Pinheiro, 2001.

2000:19. 
violações de direitos) e versatilidade (num gradiente que se estende da sua forma de violência policial até a violência comunitária), ela se mostra capaz de criar e consolidar uma linguagem, bem como conformar padrões de interação social.

Diante desse contexto, quais são as transformações provocadas pela violência ao ser absorvida pelo cotidiano? A cada novo fluxo ela encontra pessoas mais resistentes ou mais tolerantes? Mais hábeis para lidar com ela a partir da sua experiência pregressa ou mais incapazes de reconhecê-la como tal?

Como vimos desde o primeiro capítulo, as causas associadas ao fenômeno da violência urbana, particularmente às mortes traduzidas pelas taxas crescentes de homicídios durante duas décadas, são sempre pensadas num coletivo de determinantes. Mas, ainda assim, é possível identificar camadas, tanto no plano individual como coletivo, onde a violência se inscreve.

É possível, por exemplo, diferenciar as causas estruturais e os fatores de risco capazes de detonar episódios desse tipo tais como armas e o álcool. Para Caroline Moser ${ }^{301}$ esses são dois nichos explicativos distintos. Enquanto os fatores de risco são situacionais, as causas estruturais estão relacionadas à relações desiguais de poder ${ }^{302}$. Ambos servem como pano de fundo para a experiência pessoal da violência. Essas realidades individuais, contudo, se manifestam, num contexto mais amplo onde também estão em jogo e em tensão estruturas de poder nos campos econômicos e sociais.

Com efeito, temos três conceitos inter-relacionados: estrutura, identidade e agência. A noção de identidade está vinculada de maneira muito próxima à idéia de "agência humana individual". A autora vê na expressão um argumento que reconhece indivíduos como atores sociais que se deparam com modos alternativos de formularem seus objetivos ainda que seus recursos sejam restritos" ${ }^{303}$. Mas se o risco, assim como os cálculos e as escolhas fazem parte da experiência democrática, essa fórmula precisa ser revista quando o repertório de possibilidades é reduzido e as consequiências desses riscos e escolhas não são as mesmas para todos.

A fluidez com que a violência transita já foi apontada anteriormente como uma das suas características fundamentais. $O$ resultado desse continuum de violência entre os espaços - físicos e simbólicos - é que acabamos por aprender e nos acostumar com ela. Talvez resida aí uma das suas maiores perversões. Aprende-se nas próprias instituições socializadoras: escola, família, no sistema de justiça criminal, no mundo do trabalho e na vida comunitária. Esses que são

3012004 .

302 Idem: 8 .

${ }^{303}$ Ibidem: 8 (tradução minha). 
originalmente espaços de socialização, de constituição de identidades, tornam-se também espaços para aprender a conviver com a violência. A intercomunicação entre os tipos de violência acaba por criar uma rede de medo e de insegurança.

Lembremos que na época em que estava ameaçado de morte e exilado da região, Marcelo aprovava a prática policial de matar os criminosos no seu bairro. Lembremos também que antes e depois desse período ele, assim como os bandidos mortos, também foi vítima de abusos da polícia. Entretanto, essas parecem ser situações formuladas em arenas sociais diferentes - Marcelo não interpreta a morte ilegal dos criminosos locais como uma versão da agressão praticada contra ele e seu amigo pelos policiais. Não se vê como vítima da subversão de direitos dessa mesma natureza. Ou, se enxerga assim, sua afirmação de que "esse é o único jeito" retrata sua resignação na descrição de um cenário que aparentemente não carrega muitas alternativas além dessa.

Durante todo o trabalho viemos tentando apreender esse processo de construção de uma sociabilidade que incorpora a violência como dado. Mas além de identificar processos múltiplos de exclusão (aqui num sentido genérico), fazer o caminho inverso parece um exercício interessante. Olhando para as repostas dadas ao problema evidenciam-se duas arenas de interação com a violência: arena social $x$ arena penal.

Antes de avançarmos no argumento, vale a pena reagruparmos elementos dispersos ao longo desse trabalho para caracterizar um contexto mais preciso. São muitos os elementos e as formas como eles se arranjam: mercado ilegal de armas de fogo, jovens com parentes no sistema prisional, violações da polícia, privatização da resolução de conflitos, as etiquetas das ameaças, os matadores profissionais, o medo da justiça, as barreiras estruturais como o desemprego, a baixa e má escolaridade, as drogas. Mesmo que não seja possível ou proveitoso falar em uma causa, fica evidente que esse é um processo e que, mais do que isso, é um processo de natureza essencialmente social, com problemas dessa ordem.

Mas ainda que o desenho do problema seja evidente, a resposta é deslocada; não encaixa. Nossa sociedade parece ter elegido a arena penal para responder à violência urbana. A violência é tratada exclusivamente como crime, passando por um processo de desfiguração do seu sentido social.

As taxas de encarceramento cada vez mais altas nos Estado Unidos inspiraram a oposição sugerida por Wacquant ${ }^{304}$ entre o Estado-providência ao Estado penal. 0 autor revela como o

${ }^{304} 2001$. 
abatimento do primeiro permitiu e cultivou a expansão do segundo, aumentando o controle do Estado sobre o corpo social.

Em se tratando da violência expressa pela criminalidade as práticas do Estado podem ser bons guias interpretativos para pensar a oposição entre social e penal, mas não são suficientes. Vimos como ela não está apenas na vida daqueles que estão no crime, não é praticada exclusivamente por criminosos e o mais importante, impõe limitações de ordem social de maneira difusa. Ao mesmo tempo, consolida um léxico que questiona o discurso democrático ao mesmo tempo em que revela como ele não está disponível.

Retomemos a discussão do início do capítulo quando o silêncio de meus interlocutores no churrasco na nossa conversa sobre minha profissão explicitou o distanciamento ou mesmo o medo que eles têm da idéia de segurança. Esses são sentimentos que ganham ainda mais sentido quando considerada a seletividade das respostas que vêm sendo formuladas para tratar dos problemas associados à segurança pública. Ao eleger a arena penal como pano de fundo, estamos imediatamente selecionando os beneficiários e também as vítimas das políticas de segurança.

Refaçamos o percurso descrito desde o início desta tese. Estamos falando de pobres matando pobres, de um Estado que quando atua como violador de direitos elege os pobres como vítima preferencial. Sendo essa parcela da população a maior vítima, ela deveria ser, naturalmente, prioridade das políticas de segurança - pensadas aqui como um direito que garante a proteção de cada cidadão contra a violência. Mas, ao contrário, na sua fórmula repressiva, a política de segurança incide quase que exclusivamente sobre os mesmos pobres. 0 que sobrou para eles? Num sentido holístico, portanto, a violência não apenas impõe a morte a esses jovens, como vitimiza de múltiplas formas toda a órbita social ao seu redor, aprisionando-os num ciclo alimentado por mais punição, pela ausência de amparo e pela redução da autonomia.

Com efeito, ainda que histórias de exceções sempre possam ser encontradas, de um jeito ou de outro - pela violação de direitos, pela punição proveniente do aparato estatal ou pela vitimização entre pares - a violência acaba por confinar e sentenciar o destino dessa população.

E as custas desse conjunto de escolhas, é criado nosso sentimento de justiça. 


\section{Fim de partida, começo de jogo: Filhos da Terra Futebol Clube}

Em 2006 o São Paulo fazia uma ótima campanha na Copa Libertadores da América e, animada com o desempenho do meu time, apostei uma caixa de cervejas com Pedrão, morador do Parque Novo Santo Amaro, que venceríamos o Internacional na final e levaríamos o campeonato.

Pedrão é corinthiano, mas o Corinthians já havia sido desclassificado há tempos nas primeiras fases da Libertadores e torcer contra o São Paulo parecia ser a regra na final não apenas para ele, mas para todos os corinthianos. Para a alegria de Pedrão e minha tristeza, o São Paulo surpreendentemente perdeu o primeiro jogo, comprometendo a vitória na partida final.

Paguei a caixa de cervejas num churrasco onde estava sendo comemorada mais uma vitória do "Filhos da Terra Futebol Clube"; um dos times de futebol do bairro, o time em que Marcelo joga como goleiro desde 1997.

A generosidade de Pedrão diante da minha derrota foi a suspensão do "bico seco". Eu perdera a aposta, mas não seria punida com a proibição de beber a cerveja empenhada na disputa. Assim, pudemos todos comemorar a vitória do time enquanto eu ouvia as provocações a respeito do desempenho do São Paulo.

O futebol foi um tema constante nas relações estabelecidas com meus sujeitos de pesquisa. Eu fazia parte de uma minoria são-paulina e esse era sempre motivo de discussão ou provocações. Mas mais do que isso, o futebol entre eles era permanentemente um tema. Sua importância era evidenciada de muitas maneiras. Nas conversas apaixonadas sobre times rivais, na reunião de amigos para assistir as partidas juntos no bar, na maneira como o bairro se transfigurou na época da Copa do Mundo de 2006, virando uma paisagem verde e amarela.

No cemitério São Luiz, localizado entre os distritos do Capão Redondo e do Jardim Ângela, o maior da Zona Sul e um dos maiores da América Latina ${ }^{305}$ duas coisas chamam a atenção: a pouca idade dos mortos lá enterrados e o fato de que muitas das covas além do nome, data

\footnotetext{
${ }^{305}$ É nesse cemitério que acontece o maior número de sepultamentos gratuitos da cidade. Estima-se que $80 \%$ dos seus 150.000 sepultados tiveram mortes violentas. Desse total, dois terços seriam homens, com idades variando entre 13 e 25 anos. O cemitério é por si só um universo rico em símbolos que retratam a violência na região. Uma caminhada pelo cemitério São Luiz revela uma divisão entre as "covas dos ricos" e as "covas dos pobres", nas palavras nativas. As primeiras abrigam caixões enterrados. Já as segundas são covas rasas, onde o corpo é enterrado diretamente. Segundo alguns relatos, quando chove muito, e há deslizamento de terra, alguns dos corpos enterrados nas covas dos pobres ficam aparentes. Verdade ou não, esse é um dado que compõe a mitologia local.
} 
de nascimento e morte e eventualmente uma foto, trazerem a insígnia do time de futebol do falecido.

“A Macaca" era o apelido do Grêmio; o primeiro time de futebol do Parque Novo Santo Amaro. Fundada no início dos anos 70, a equipe reunia os primeiros moradores do bairro, a maioria imigrantes, recém-chegados em São Paulo. Os jogos da “Macaca” eram realizados num outro campo do bairro, menor, num tempo em que a paisagem em volta, diferente do que é hoje, ainda tinha muito mato e poucas casas.

Nessa época, o campo atual era um brejo e foi apenas em 1978, fruto da mobilização comunitária, que o bairro ganhou o campo que tem hoje. Nas palavras de Mundinho, jogador desde os tempos da Macaca, "a gente lutou muito pra ter esse campo".

Acompanhando o crescimento da região, o número de equipes também aumentou, e hoje o Parque Novo Santo Amaro tem mais de dez times de futebol, sendo três deles descendentes diretos da "Macaca": o “América", fundado em 1981; o “Cheira Cola”, de 1986 e o mais jovem, fundado em 1992, "Filhos da Terra Futebol Clube".

Seus jogadores alegam que dentre todas as equipes da vizinhança, o FTFC é o time mais querido do bairro. A avaliação, claro, não é desinteressada e não é possível saber o quanto esse atestado de popularidade corresponde à realidade. Talvez os jogadores do "América" tenham a mesma opinião a respeito de seu próprio time. Mas o fato é que a história dos times de futebol no bairro, e particularmente a trajetória do Filhos da Terra Futebol Clube, se misturam com a história do Parque Novo Santo Amaro. A centralidade física que o campo de futebol tem na geografia do bairro é reproduzida na importância que o time e as partidas têm na vida dos moradores em geral, e não apenas para os jogadores das equipes.

Ninha, centroavante e primo de Marcelo, jogava no FTFC desde os 15 anos. Depois disso foi jogar no “América”, até ser convidado por Marcelo a voltar. Quando retornou ao time, Ninha já era um homem casado. Ele conheceu sua mulher enquanto ainda jogava no "América". Torcer enquanto Ninha jogava foi uma das etapas do namoro dos dois. Talvez isso explique o fato de que mesmo com a volta de seu marido ao FTFC, ela não consiga deixar de ser uma torcedora fanática do "América"; o que é motivo de piada entre os outros jogadores.

Quando entrevistados, ambos recorrem ao time para me contar como se conheceram. Ao mesmo tempo, ao comentar sobre o time, Ninha lembra sempre de como deu início ao relacionamento com sua mulher. 
Como o próprio Ninha define, "O campo é o centro de tudo, é a única diversão que tem aqui no bairro". Logo, conhecer e pensar a sociabilidade local é uma tarefa impossível sem atravessar o campo - seja fisicamente, seja no plano das idéias ${ }^{306}$.

Assim como no caso de Ninha e Marcelo, muitos filhos de ex-jogadores, irmãos e primos compõem a equipe que acaba sendo, portanto, também um reduto de histórias de vidas dessas pessoas e das suas famílias. $\mathrm{O}$ caso de Neca, zagueiro e atual presidente do time e da comissão técnica é exemplar nesse sentido. Seu irmão, Pampa, também é zagueiro do "Filhos". Foi jogar inspirado por seu irmão mais velho; a mãe dos dois é a roupeira do time e sua neta, filha de Neca, não perde uma partida.

O irmão de Uca - Betinho - um dos fundadores do time, também jogava no "Filhos da Terra", mas parou desde que "virou crente". A família dos dois é conhecida por estar sempre presente nos jogos. Cosme e Caio também são irmãos que jogam juntos no time.

Desde menino André Rosa era um torcedor fanático do FTFC. Antes de ter idade suficiente para integrar o time, ele era o pegador de bola da equipe. Seu pai era jogador desde os tempos da "Macaca".

Em suma, o time resume três gerações do bairro; desde os primeiros moradores, até seus filhos que hoje jogam e os netos que pretendem jogar.

Mas o envolvimento da comunidade com o time ultrapassa as relações familiares. Wilson, o dono do bar que fica na beira do campo, criou vínculos com as pessoas e com o próprio bairro por meio da relação estabelecida entre o espaço do bar e o do próprio time. Hoje, já é uma tradição: ele recebe a equipe depois dos jogos. É no seu bar que os jogadores vão comemorar as vitórias ou lamentar as derrotas. É lá também que as reuniões administrativas sobre o time acontecem.

Mas as relações do time não ultrapassam apenas os limites do campo. Em 2003, a equipe quase acabou por conta da falta de orçamento. Hoje, conta com um patrocínio de um

\footnotetext{
${ }^{306}$ As ciências sociais têm tratado a prática esportiva, particularmente o futebol, como um campo rico para pensar a sociedade brasileira. Os já clássicos ensaios de Roberto DaMatta $(1982,1994 b)$ inauguram essa trilha, propondo, a partir de uma abordagem etnográfica, uma interpretação "totalizante" do jogo de futebol, capaz de revelar aspectos socioculturais do esporte no Brasil. Luiz Henrique de Toledo (1996) trata os jogos como "situações rituais" para desvendar as dimensões simbólicas do futebol brasileiro. As categorias analíticas escolhidas pelo autor: profissionais, especialistas e torcedores, permitem que o futebol seja pensado em arenas diversas de representação.

Mais recentemente, num ensaio sobre um tradicional jogo de futebol "Pretos X Brancos", que acontece sempre no final do ano, na favela de Heliópolis, em São Paulo, Lilia Scwarcz (2007) reflete sobre a variação nas cores atribuídas aos jogadores, dentro de campo e fora dele. A antropóloga mostra uma clara correspondência entre o jogo em si, o status social que ele lembra e atualiza, a cor dos jogadores e os muitos significados sociais que esse conjunto adquire.
} 
“empresário”, dono de uma padaria no Butantã, e que não reside na região. Graças ao patrocínio, o time tem um uniforme novo e pode fazer a festa de final do campeonato, fora do bairro, onde as famílias dos jogadores se reúnem para comemorar as conquistas do ano.

Mas por que falar de futebol numa tese que até agora só tratou de violência?

Desde o início do trabalho sempre apontamos que a vida daqueles que estavam expostos a altas doses de violência, não se encerrava na violência - era mais rica e variada do que o lugar de vítima pode sugerir. No entanto, por outro lado, sabemos que sendo ela tão aguda, é difícil transpor essa dimensão e olhar para esses outros redutos de sociabilidade.

O time de futebol é uma dessas outras faces do bairro. Mas ganha uma conotação especial, porque é capaz de acessar elementos que não dizem respeito exclusivamente ao time de futebol. Conhecer sua história é também um caminho para conhecer a história do bairro e de seus moradores. É falando do time que todo mundo declara que não tem vontade de mudar do bairro. É também falando do time que cada um comenta sobre sua vida, seus desejos e expectativas.

Em Orientalismo ${ }^{307}$, Eduard Said lança uma das idéias que fundamenta os Estudos PósColoniais.

Mapeando a construção do Oriente nas obras literárias, nos discursos políticos e nos relatos de viagem europeus, o autor revela um processo de construção do outro, no seu caso o Oriente, que além de pouca correspondência com a realidade, serve como instrumento de dominação.

Seu argumento enfatiza como a representação construída acerca do "outro" contribui para a definição do "eu". No caso abordado pelo autor palestino, a representação que o Ocidente fez do Oriente foi fundamental, segundo ele, para que o próprio Ocidente se definisse como tal e pudesse, a partir das diferenciações estabelecidas, legitimar seu projeto político.

O processo de construção das representações identificado por Said nos interessa como modelo na medida em que explicita como "selecionar elementos" faz parte da tarefa de construir as imagens de si e do outro. No nosso caso, como os moradores do Parque Santo Amaro se representam e quais são as escolhas feitas para compor sua imagem e a imagem do bairro?

Ainda que a violência seja um traço distintivo da região e imponha, como vimos, uma série de constrangimentos aos seus moradores, o time de futebol e o gosto pelo esporte são os elementos escolhidos e privilegiados quando a tarefa é contar a história do bairro, valorizar as relações entre moradores e refletir sobre o futuro - no plano coletivo e individual.

${ }^{307}$ Said, 1979[2000]. 
Mas o argumento também é um bom ponto de partida reflexivo porque o enunciado que circunscreve a relação Ocidente/Oriente pressupõe complementaridade nessa relação. Tal como ocorre entre o legal e o ilegal que caracteriza as muitas formas de lidar com a criminalidade violenta. Todavia, ao reconhecer que esses são processos capazes de legitimar e cristalizar instrumentos de dominação, Said está chamando a atenção para a assimetria de poder entre as partes implicadas na interação. $E$, nesse sentido, não é possível desconsiderar a maneira como a violência, em São Paulo, vitimiza de maneira desigual o corpo social.

Ao criticar as análises de Said, o crítico literário Homi Bhabha reivindica a percepção de que a relação entre Ocidente e seus "outros" não pode ser entendida apenas como uma relação vertical de dominação/subordinação ${ }^{308}$. Segundo Bhabha, as relações entre colonizador/colonizado carregam ambivalências e, assim como no discurso colonial, o colonizador, ainda que dominante, incorpora traços do colonizado (mesmo que imaginados) e o colonizado também absorve características (mesmo que imaginadas) próprias do discurso do colonizador.

A tensão entre os modelos de Bhabha e Said é proveitosa para pensarmos de que maneira os diversos atores sociais se engajam nesse cenário de violência difusa e como, nesse universo, são elaborados os lugares de vítima e algoz.

Do ponto de vista das reflexões contidas nesse trabalho, trazer a história do time faz sentido porque, de maneira particular, ele representa uma espécie de oposto complementar à idéia de que a fragilidade dos laços sociais locais podem explicar a violência. Mais do que isso, revela também uma recusa, por parte dos moradores do PNSA, do lugar exclusivamente de vítima.

A articulação e alcance do time e das redes de sociabilidade que ele fomenta questionam esse tipo de interpretação, mostrando como - para o bem e para o mal - uma comunidade que está sujeita a grandes doses de violência e tudo aquilo que ela carrega, é capaz de absorvê-la e aprender a viver com ela. Mais ainda: traduz e cria novos significados.

Retomando o argumento de José Vicente Tavares dos Santos, o capitalismo, a globalização, o consumismo desenfreado, em diferentes níveis, cumprem papéis importantes na consolidação de uma forma de sociabilidade marcada por um processo de fragmentação e exclusão econômica e social. Para o autor, a desagregação social está nas bases das explicações sobre os altos índices de violência difusa na nossa sociedade ${ }^{309}$.

\footnotetext{
3081998.

309 Tavares dos Santos, op.cit.: 4.
} 
Aludir à obra de Norbert Elias é um pressuposto nesse debate. 0 autor alemão, respeitadas todas as diferenças, aponta de maneira clara para tais variações, considerando a estabilidade das relações, entre as sociedades com e sem o monopólio da força.

“[...] as sociedades sem um monopólio estável da força são sempre aquelas em que a divisão de funções é relativamente pequena, e relativamente curtas as cadeias de ações que ligam os indivíduos entre si. Reciprocamente, as sociedades com monopólio mais estáveis da força, que sempre começam encarnadas numa grande corte de príncipes ou reis, são aquelas em que a divisão de funções está mais ou menos avançada, nas quais as cadeias de ações que ligam os indivíduos são mais longas e maior a dependência funcional entre as pessoas. Nelas o indivíduo é protegido principalmente contra ataques súbitos, contra a irrupção de violência física em sua vida. Mas, ao mesmo tempo, é forçado a reprimir em si mesmo qualquer impulso emocional para atacar fisicamente outra pessoa [...] A moderação das emoções espontâneas, o controle dos sentimentos, a ampliação do espaço mental além do momento presente, levando em conta o passado e o futuro, o hábito de ligar os fatos em cadeias de causa e efeito - todos estes são distintos aspectos da mesma transformação de conduta, que necessariamente ocorre com a monopolização da violência física e a extensão das cadeias da ação e interdependência social. Ocorre uma mudança 'civilizatória' do comportamento."’10

Elias descreve um outro contexto, de formação e consolidação do Estado moderno, mas o longo trecho citado traz modelos inspiradores não apenas para pensar nas oposições entre um tipo e outro de sociedade, mas também nos espaços de intersecção.

A diferença essencial entre os dois modelos de sociedade está no grau de divisão de funções e na longevidade das cadeias que ligam os indivíduos uns aos outros. Em outras palavras, a coesão e interdependência social seriam resultados de um processo de transformação civilizatório, que garantiria a pacificação social.

A história do "Filhos da Terra Futebol Clube" nos permite, todavia, problematizar essa relação. É importante porque ela representa um contraponto ao argumento da desagregação social. Cria um campo alternativo onde as relações são travadas. Permite refletir sobre os mesmos problemas a partir de uma nova ótica.

O "Filhos da Terra" é sem dúvida, um elemento de associativismo no bairro. Seu João, presidente da Associação de Moradores, sempre se lamentava das dificuldades de mobilização no local. A despeito de seus inúmeros esforços - como a reforma da sede, a biblioteca comunitária, a tentativa de oferecer consultas odontológicas, a Associação de Moradores continuava não sendo um espaço freqüentado pela comunidade local. Nos seus planos estavam, por exemplo, discutir a relação com a subprefeitura, organizar as reivindicações para o posto de saúde local e outros temas essenciais ao bairro. Mas a verdade é que a Associação só era freqüentada porque era a representante da Prefeitura no Programa de distribuição de leite e oferecia um curso de alfabetização de adultos. Para além desses momentos pontuais, foi sempre muito difícil levar a comunidade para dento da Associação.

${ }^{310}$ Elias, op. cit.: 198. 
Com o time ocorria exatamente o oposto. Os testemunhos dos jogadores mostram como as relações estabelecidas por meio da equipe de futebol ultrapassam os limites do campo, envolvendo as famílias, os comerciantes e a torcida em atividades coletivas, que podem ter sua origem num evento relacionado ao time, mas que se desdobram em muitas outras relações, em momentos diversos daqueles que transcorrem efetivamente no campo de futebol.

Mas é possível ir além: o time e o campo são também pontos de apoio para repensar o passado e para projetar o futuro.

Mundinho, que chegou a jogar na "Macaca”, é torcedor do Santos e fez questão de vestir a camisa do time ao ser entrevistado; tamanha a seriedade com a qual encara o futebol. Conta que antes a região era só mato, e misturando a história da sua vida com a história do bairro, diz que as coisas melhoraram. Quando ele chegou em São Paulo, era difícil encontrar um emprego, era difícil alguém "pegá-lo” como pedreiro; atividade que ele mesmo desconsidera como profissão. Mas aos poucos as coisas foram melhorando e o mesmo, de acordo com a sua leitura, aconteceu com o bairro: “não tinha luz, não tinha água, não tinha asfalto, nem rua tinha" e agora "já tá uma grande coisa, mas ainda precisa de muita coisa".

O que ele quer para o futuro? Ver o campo gramado, e transformar tudo aquilo num clube onde as crianças possam jogar: "o Parque Novo Santo Amaro merece ter um campo". A declaração não deve ser escutada como ingênua. Ao longo de 30 anos, Mundinho acompanhou as mudanças ocorridas no bairro e conseguiu enxergar nelas algumas melhoras, sobretudo no que se refere às condições mais estruturais - de fato, como apontamos em outros momentos da tese, a periferia de São Paulo observou melhoras nas condições de vida. No Parque Novo Santo Amaro, assim como em outras regiões, isso se traduziu em mais ruas asfaltadas, no acesso praticamente irrestrito à telefonia, entre outras coisas. Nesse mesmo período Mundinho viu as crianças crescerem para virarem os jogadores atuais do "Filhos da Terra". Na sua fala fica estabelecido um paralelo entre essas dimensões e a idéia de que a melhoria no campo significaria também uma melhora do bairro e, conseqüentemente, uma melhora no padrão de vida local e na sua própria vida.

Sua frase é traduzida por outros jogadores de maneira ainda mais objetiva. Marcelo identifica a falta de espaços de lazer e o campo como a única opção nesse sentido. Neca "faria um mini-estádio para tirar as crianças da rua". O campo conjuga razão prática e razão simbólica. Seu valor está tanto naquilo que ele significa, quanto no que ele pode proporcionar. Com 
efeito, os benefícios para o campo repercutiriam positivamente na vida do bairro como um todo.

Zé Grande é um morador antigo do bairro, que tem uma carreira extensa na cena esportiva local. Ele jogou na "Macaca" e também no "América". Nunca chegou a jogar no "Filhos da Terra”. Mas seu filho, Veio, hoje é titular. Sem ter tanta certeza de que eles de fato jogam bem, "eles dizem que jogam bola, eu vejo todo mundo correndo atrás da bola", fala fazendo graça do time. Zé Grande diz que aconselha seu filho a "jogar bem e a não se meter em encrenca com ninguém". Sonha com a possibilidade de que ele seja contratado por um time maior.

Para Marcelo, sua posição de goleiro no time é entendida como um bem, uma verdadeira propriedade. Contrastando com sua juventude, ele já fez seu plano de carreira no time que inclui até o momento da "sucessão": aspira jogar mais oito anos, se aposentar, e passar a vaga para seu filho. Se define como "turrão" e por isso não pretende dar a vaga para qualquer um.

O que a história do "Filhos da Terra" e de seus jogadores nos mostra é que existe agregação. Há laços entre as pessoas, e entre as pessoas e o bairro. A despeito do inquestionável contexto de privação, agregado a altos índices de violência, os moradores do Parque Novo Santo Amaro conseguem projetar um futuro para o bairro, para eles e para seus filhos. Um futuro no próprio bairro, de onde eles não têm vontade de mudar. Como destaca Neca "a gente gosta do bairro, é uma vida que a gente construiu aqui ... a gente aprendeu a gostar do bairro, se for prá sair tem que ser prá uma coisa bem melhor". Assim como ele, outros entrevistados valorizam as relações construídas no bairro. Como era de se esperar, todos declaram almejar uma vida melhor. Mas essa vida pode ser construída no Parque Novo Santo Amaro.

Como então pensar esse grau de violência numa moldura de normalidade das relações sociais?

Michael Taussig afirma que o terror deve ser encarado como uma questão de distância. Ou melhor, trata- se de encontrar a distância correta: nem tão perto que ele se volte contra você, nem tão longe que fique imperceptível e acabe substituído por outra forma de terror ${ }^{311}$. 0 autor, contudo, ressalta nossa dificuldade em reconhecer o terror em nós mesmos, e mostra como é mais fácil enxergá-lo no outro, ou em outros lugares, preferencialmente

3111992 in 2004:269. 
distantes. "É como se a selvageria da escuridão do terror dos outros servisse para dar silhueta à nossa luz ${ }^{312 »,}$ diz Taussig.

Apoiando-se em Walter Benjamim, o antropólogo australiano alega que o "estado de emergência" não é a exceção, mas a regra. Reivindica o reconhecimento de que vivemos um estado de emergência crônico como única estratégia para que nosso esforço de revelar e esconder o terror ao mesmo tempo, não faça com que ele seja incorporado de maneira imperceptível à nossa vida cotidiana.

Acompanhando um pedaço da trajetória de Marcelo, pudemos ver como a violência entra e sai de sua vida de maneira intermitente: os constrangimentos por parte da polícia, a ameaça do matador local, seu desejo de vingança, a ameaça sofrida por seu tio, o jovem adotado e posteriormente "desadotado", que não consegue romper com a vida de infrações. 0 roteiro sugere que a violência faz parte da sua vida de maneira indissociável e que assim será até o final dela.

No entanto, ao mesmo tempo, a violência é tomada como uma situação de anormalidade. Episódios criminosos são interpretados como a exceção da regra. Vivemos um contrato que é quebrado quando episódios de violência irrompem. Mas, num cenário de criminalidade deflagrada, esse contrato parece ser quebrado tantas vezes, que somos tentados a questionar sua existência.

Essa oscilação permanente impõe a pergunta: a violência, afinal, pertence à regra ou se configura como um espaço social de exceção? Mais do que isso, quais são as conseqüências dos cenários implicados nos dois casos?

É interessante refazer o percurso percorrido pelos capítulos dessa tese e mostrar como esse trabalho procurou responder a essas perguntas explorando alguns nichos explicativos.

A partir dos dados levantados em São Paulo, e interpretando os índices definidos como violência urbana e expressos pelas altas taxas de homicídios, retratamos a difusão da violência na sua forma de criminalidade urbana. Refizemos também a trajetória histórica e social dessa categoria, mostrando como ela pode se referir a episódios envolvendo graus maiores ou menores de violência. Essa diversidade é fundamental para que ela seja percebida como "difusa": o medo e a sensação de insegurança, um seqüestro nos Jardins, um assalto no farol e um homicídio na periferia confundem-se como um só fenômeno. Reside nas suas dimensões abstratas e concretas, nas ações e representações ligadas à violência, seu potencial quase que infinito de criação e de reprodutibilidade.

${ }^{312}$ Op. cit.: 269 . 
Há, porém, nesse cenário algumas particularidades. A análise dos homicídios do DHPP, confrontada com alguns casos relatados, começa a desenhar um cotidiano que abriga a violência nas relações interpessoais, travadas nos espaços de convivência.

Descrevendo um dos bairros conhecidos como um dos mais violentos da Zonal Sul, sublinhando sua condição de vulnerabilidade social, pudemos colocar a violência em contexto. A partir de um cenário específico de privações foi possível falar de seus alvos preferenciais: jovens, homens, moradores das periferias de São Paulo.

A etiqueta que dita imediatismo nas soluções, imposta pela dinâmica das ameaças, deixa transparecer novas regras de conduta e de comportamento. Em cada interação, as relações de poder são redefinidas e renegociadas, tendo como pano de fundo a possibilidade de matar e morrer. Está indicada aí, pois, a construção de um novo tipo de sociabilidade onde a morte não só é tolerada, mas é um desfecho possível e legítimo para conflitos do cotidiano.

Ficam, assim, explícitas algumas características essenciais da violência aqui praticada: sua aleatoriedade, seu caráter corriqueiro, a maneira como episódios graves podem ser absorvidos pelas vítimas e solucionados na medida e com os recursos possíveis, para virarem uma história que ficou para trás. Episódios se repetem em número suficiente, com roteiros semelhantes - são muitos os refugiados urbanos -, para que ocupem um lugar limiar entre o cotidiano e a exceção. Nesse sentido, impõem uma reflexão sobre o caráter transformador de tais processos. A mudança na vida prática é mais óbvia. Acompanhamos, por exemplo, as conseqüências das ameaças feitas a Marcelo, a seu tio ou à mãe do jovem que foi morto pelo tráfico. Mas que tipo de transformações elas estão promovendo na forma de se relacionar com as pessoas, com a comunidade, ou com as instituições. Quais são as mudanças envolvidas, se é que elas existem?

Para tanto é preciso reconhecer que os mecanismos legítimos para enfrentar a violência nem sempre (ou quase nunca) estão disponíveis. Essa equação complexa revela um desequilíbrio entre a capacidade e disposição do aparato estatal para punir e sua incapacidade de proteger, circunscrevendo também regiões refratárias à ação da justiça. Mas, nesse caso, a impunidade não deve ser entendida como um benefício. Ao contrário, ela também vitimiza as regiões, as pessoas e distorce as representações sobre a pobreza. Não obstante, se o limite é desenhado de maneira tão explícita, as fronteiras entre a vida no crime e a vida fora dele não são tão óbvias, apresentando muitas versões ou gradações. Da mesma forma que é possível apontar quem "é do crime" e quem não é, estamos falando também de pessoas que cresceram juntas, compartilham de uma convivência e são, em alguns casos, amigas. 
O crime organizado ou semi-organizado reivindica seu lugar como flexibilizador de regras, imprimindo um novo léxico que influencia o padrão das relações cotidianas, resultando numa sociabilidade em permanente construção, apoiada num meio termo que combina modelos do "certo" e do "errado", do crime e da lei, tendo sua gravidade acentuada pela distância da justiça.

O percurso social do envolvimento do jovem com o universo da criminalidade, assim como a incorporação da violência e da própria criminalidade como padrão e referência nas suas relações sociais foi reconstruído e problematizado a partir de dados quantitativos.

Os dados trazidos possibilitaram uma reflexão sobre alguns condicionantes contextuais ligados ao envolvimento dos jovens com a criminalidade e de que maneira eles são capazes de conformar redes de ilegalidade. Envolver-se com o crime é, nesse sentido, o resultado de um processo extenso e com muitas camadas, que inclui suas condições de vida, suas relações familiares, as interações com outros círculos sociais e é claro, suas escolhas.

Com isso estamos falando também das dimensões políticas, simbólicas e até mesmo ideológicas do debate em torno das causas da violência e das bases materiais, sociais e políticas para a produção e reprodução da violência.

Essa rede de medo e insegurança é completada pela gestão alternativa de contenção ou de imposição da ordem. A fragilidade e a incapacidade do Estado, expressas nos abusos e violações praticadas, somadas à sua incapacidade de proteger contribui para que a gestão privada da segurança e da punição, nas suas múltiplas formas, ganhe proporções capazes de questionar o modelo democrático e alimentem a criação e manutenção de um espaço nebuloso, onde o legal e o ilegal se encontram e se complementam.

Desse modo, a segurança é resignificada de maneira distorcida, ganhando uma versão excludente e exclusiva, calcada na imagem da repressão, deixando um vácuo onde deveria haver direitos.

O quadro refeito pela trajetória das idéias deve ser completado com a sutileza perversa da violência que nem sempre é evidente e pela experiência verificada pela etnografia apresentada ao longo da tese.

Um bom exemplo nesse sentido é que durante os três anos em que freqüentei o Parque Novo Santo Amaro, nunca vi uma arma. Claro que elas estão lá, mas eu jamais vivi uma situação em que elas aparecessem. 
Sempre me lembro da ocasião em que fui visitar o projeto para jovens coordenado por um amigo na favela da Maré, no Rio de Janeiro. Entrei sem problemas na favela. Mas na hora de sair, já no final da tarde, não pude ir embora sozinha porque havia muita gente armada nas ruas. Tive que ser escoltada até o lado de fora. Esse é um tipo de cenário que eu nunca vivi no local em que etnografei.

Não pretendo com tal afirmação negar a existência de situações como essa em São Paulo. Mas sim, chamar atenção para o fato de que num bairro considerado como um dos mais violentos da Zona Sul, a violência não se expressa dessa maneira.

A violência também aparece de maneira difundida, mas mais dissipada, na medida em que vai sendo incorporada ao cotidiano; sem que tal afirmação implique pensar que vivamos num estado de supressão total das normas ou de qualquer regramento. Estamos falando num reoordenamento social cujas bases são relações que toleram, reconhecem e legitimam a violência. A violência deixa de ser ato de exceção.

A noção de cosmologia, tão preciosa para a antropologia, se mostrou uma categoria versátil, capaz de iluminar as formas de elaborar o mundo por parte dos sujeitos de pesquisa da etnologia indígena brasileira, bem como dos havaianos retratados por Marshall Sahlins ${ }^{313}$. Anthony Seegers ${ }^{314}$ define cosmologia como o modo por meio do qual os membros de uma determinada sociedade concebem seu universo e contemplam nessa construção suas reflexões sobre os "outros" e sobre si mesmo. A definição de Seegers é cuidadosa ao incluir nesse processo de construção as práticas do cotidiano.

A noção de cosmologia se mostra, assim, um bom suporte para olhar para a violência como uma ordem cultural $^{315}$.

Pudemos acompanhar a partir dos episódios violentos relatados e suas conseqüências como, ao ser incorporada à vida cotidiana, a violência torna-se mais um meio para entender a produção da vida social, passando a integrar nossas "formas de elaborar o mundo".

Os episódios mostram como incorporá-la e tocar a vida, a despeito das limitações é uma estratégia para sobreviver. Quais seriam, porém, as conseqüências e os riscos envolvidos nessa estratégia? Estaríamos diante de um Estado de Direito mais flexível?

Sem dúvida é preciso proteger-se; reconhecer a violência e até reagir a ela. Essas atitudes não significam, no entanto, necessariamente uma disposição para enfrentá-la. 0 modo como

\footnotetext{
3131988 .

3141981.

${ }^{315}$ Sahlins, idem.
} 
viemos lidamos com a violência revela estratégias de quem foi capaz ou compelido a naturalizá-la. Ao acomodá-la no cotidiano estamos revelando uma incapacidade de rejeitá-la por completo.

As estratégias que acionam a segurança privada, as milícias, as soluções privadas de conflitos são todos indicativos por um lado de que a violência não é um estado de exceção, mas parte do dia-a-dia. Por outro, são sinais muito contundentes de que não estamos dispostos a combater a violência ou enfrentá-la, mas estamos criando mecanismos que nos permitam viver com ela ou sobreviver a ela.

A violência não pode ser pensada em abstrato. Vale a pena contemplá-la no campo das relações sociais. Na sua condição concomitante de sintoma e causa da desigualdade ela é também um exercício social de dominação. Existe uma assimetria nas condições e consequiências da sua assimilação.

Nesse sentido, a escolha pelo não enfrentamento deve ser compreendida, na verdade, como uma escolha pela manutenção de uma certa ordem. 


\section{Bibliografia}

Abramo, H.W. (1994). Cenas juvenis: punks e darks no espetáculo urbano. São Paulo: ScrittaAnpocs.

Abramovay, Mirian; Castro, Mary (coords.) (2006a). Juventude, Juventudes: o que une e o que separa. Brasília: UNESCO.

Abramovay, Mirim; Castro, Mary (coords.) (2006b). Relações raciais na Escola: Reprodução da Desigualdade em nome da Igualdade. Brasília: UNESCO.

Abramovay, Mirian; Pinheiro, Leonardo Castro (2003). Violência e vulnerabilidade social. In: Fraerman, Alicia (ed.). 2003. Inclusión social y desarrollo: presente y futuro de la comunidad iberoamericana. Madri: Comunica.

Abramovay, Mirian (2002). Juventude, violência e Vulnerabilidade Social na América Latina: desafios para as políticas públicas. Brasília: UNESCO, BID.

Abramovay, Miriam; Rua, Maria das Graças (eds.) (2002). Violências nas Escolas. Brasília: UNESCO, Instituto Ayrton Senna, UNAIDS, Banco Mundial.

Adorno, Sérgio (2002a). Exclusão socioeconômica e violência urbana. In: Sociologias Violências, América Latina, Porto Alegre, p. 84-135, 2002.

Adorno, Sérgio (2002b). O Monopólio estatal da violência na sociedade brasileira contemporânea. In: Miceli, Sérgio (org.). 1999. O que ler na ciência social brasileira. São Paulo: Editora Sumaré, ANPOCS.

Adorno, Sérgio; Lima, Renato Sérgio de; Bordini, Eliana B. T (1999). O adolescente na criminalidade urbana em São Paulo. Brasília: Ministério da Justiça/Secretaria de Estado dos Direitos Humanos.

Adorno, Sérgio (1994). Crime, justiça penal e desigualdade jurídica. Os crimes que se contam no Tribunal do Júri. In: Revista USP, São Paulo, v. 21, p. 132-51, 1994.

Adorno, Sérgio (1993). A experiência precoce de punição. In: Martins, José de Souza (org.). 1993. O massacre dos inocentes. São Paulo: Editora Hucitec.

Adorno, Sérgio (1991). Violência urbana, justiça criminal e organização social do crime. In: Revista Crítica de Ciências Sociais, vol. 33, p. 145-156, Coimbra, 1991.

Albert, Bruce (1995). Anthropologie 'apliquée' ou 'impliquée'? In: BARÉ, J.-F. (org.). 1995. Les applications de l'Anthropologie. Paris: Harmattan.

Alvarez, Marcos; Salla, Fernado; Souza, Luiz Antonio (2004). Construção das Políticas de Segurança Pública e o Sentido da Punição, São Paulo (1822-2000). São Paulo: Núcleo de Estudos da Violência da Universidade de São Paulo.

Alvim, Maria Rosilene; Valladares, Lícia do Prado (1990). Infância e sociedade no Brasil: uma análise da literatura. In: Boletim Informativo Bibliográfico em Ciências Sociais, n. 26, São Paulo/Rio de Janeiro, ANPOCS/Vértice, 1990.

Alvito, Marcos (1999). Do corpo para ser visto ao corpo invisível. In: Revista Sexta Feira [Corpo] n. 4. São Paulo: Editora 34. 
Alvito, Marcos; Velho, Gilberto (orgs.) (1996). Cidadania e violência no Rio de Janeiro. $2^{\mathrm{a}}$ ed., Rio de Janeiro: Editora da UFRJ/FGV.

Appadurai, Arjun (2004). The capacity to aspire: culture and the terms of recognition. In: Rao, V.; Walton, M. (edits.). 2004. Culture and Public Action. California: Stanford University Press, p. 59-85.

Ariès, Philippe (2003). História da morte no Ocidente: da Idade Média aos nossos dias. Rio de Janeiro: Ediouro.

Assis, Simone (1999). Traçando Caminhos numa Sociedade Violenta. A Vida de Jovens Infratores e seus Irmãos não Infratores. Rio de Janeiro: Fiocruz.

Barker, Gary T. (2005). Dying to be Men: Youth and Masculinity and Social Exclusion (Sexuality, Culture and Health). London: Routledge

Bhabha, Homi K. (1998). O local da cultura. Belo Horizonte: Editora UFMG.

Bretas, M. L.; Poncioni, P. (1999). A cultura policial e o policial civil carioca. In: PANDOLFI, D. C. et al. (orgs.). 1999. Cidadania, justiça e violência. Rio de Janeiro: Fundação Getúlio Vargas, p. 149-163.

Briceño-leon, Roberto (ed.) (2002). Violencia, Sociedad y Justicia em America Latina. Buenos Aires: Clacso.

Buvinic M.; Morrison , A.R.; Shifter M. (1999). Violence in Latin America and the Caribbean: a framework for action. In: Morrison, AR; Orlando B. E. (eds.). 1999.Too close to home:

domestic violence in the Americas. New York: Inter-American Development Bank, p. 3-34.

Caldeira, Teresa (2004). Entrevista à Revista Sexta Feira n. 7. São Paulo: Editora 34.

Caldeira, Teresa (2000). Cidade de muros: crime, segregação e cidadania em São Paulo. São Paulo: Editora 34/Edusp.

Caldeira, Teresa; Holston, James (1999). Democracy and Violence in Brazil. In: 1999. Comparative Studies in Society and History. Cambridge University Press, p. 691-729.

Cano, Ignácio; Santos, Nilton (2001). Violência letal, renda e desigualdade no Brasil. Rio de Janeiro: 7letras.

Cardia, Nancy (1997). O medo da polícia e as graves violações dos direitos humanos. In: Tempo Social, v.9, n.1, 1997, São Paulo, p. 249-65.

Cardia, Nancy (1988). A violência urbana e os jovens. In: Pinheiro, Paulo Sergio (coord.). (Org.). 1988. São Paulo sem medo: um diagnóstico da violência urbana. $1^{\text {a }}$ ed. Rio de Janeiro: Editora Garamond Ltda.

Cardoso, Ruth; Sampaio, Helena. (orgs.) (1995). Bibliografia sobre a juventude. São Paulo: EDUSP.

Cardoso, Ruth (1988). Aventuras de antropólogos em campo ou como escapar das armadilhas do método. In: Cardoso, Ruth (org.). 1988. A aventura antropológica: teoria e pesquisa. Rio de Janeiro: Paz e Terra, p. 95-125.

Caruso, Haydee G. C. ; Ricardo, Carolina de Mattos (2007). Segurança pública: um desafio para os municípios brasileiros. In: Revista Brasileira de Segurança Pública Ano 1, Edição 1, 2007. 
Carvalho, Marceloandre; Cerqueira, Daniel; Rodrigues, Rute; Lobão, Waldir (2007). Custos das Mortes por causas Externas no Brasil. Brasília: IPEA, Texto para discussão N. 1284.

Célia, Regina; Novaes, Reyes; Tojeira Cara, Daniel; Moreira da Silva, Danilo; Carvalho Papa, Fernanda (2006). Política Nacional de Juventude: Diretrizes e perspectivas. São Paulo: Conselho Nacional de Juventude, Fundação Friedrich.

Centro de estudos de Cultura Contemporânea (CEDEC) (1996). Mapa de Risco da Violência cidade de São Paulo. Centro de estudos de Cultura Contemporânea.

Centro de Estudos da Metrópole/CEBRAP; SESC; SAS-PMS (2004). Mapa da Vulnerabilidade Social da População de São Paulo. São Paulo: Centro de Estudos da Metrópole/CEBRAP.

Cerqueira, Daniel; Carvalho, Marceloandre; Lobão, Waldir; Rodrigues, Rute (2007). Análise dos custos e conseqüências da violência no Brasil. Texto para discussão N. 1284. Brasília: IPEA.

Cerqueira, Daniel; Lobao, Waldir (2004). Determinants of crime: theoretical frameworks and empirical results. In: Dados Revista de Ciências Sociais, v. 47, n. 2, p. 233-269, Rio de Janeiro, 2004.

Cesar Alvarez, Marcos; Salla, Fernando; F. de Souza, Luiz Antonio (2004). Políticas de Segurança Pública em São Paulo: uma perspectiva histórica. In: Justiça e História, v.4, n. 8, p. 173-199, Porto Alegre, 2004.

Cohen. Albert K. (1955). Delinquent Boys, the culture of the gang. Glencoe, Illinois: The Free Press.

DaMatta, Roberto (1994a). Os discursos da violência no Brasil. In: DaMatta, Roberto. 1994. Conta de mentiroso: sete ensaios de antropologia brasileira. $2^{\mathrm{a}}$ ed., Rio de Janeiro: Editora Rocco.

DaMatta, Roberto (1994b). Antropologia do óbvio: notas em torno do significado social do futebol brasileiro. In: Revista USP. Dossiê Futebol, 22, São Paulo.

DaMatta, Roberto (1982). Esporte na sociedade: um ensaio sobre o futebol brasileiro. In:DaMatta, Roberto. 1982. Universo do futebol: esporte e sociedade brasileira. Rio de Janeiro:Pinakotheke.

D’andrea, Tiaraju (2006). Visões de Paraisópolis: Violência, mídia, representação. In: Sexta periferia. In: Revista Sexta Feira [Periferia] n. 8. São Paulo: Editora 34.

Davis, Mike (2006). Planet of Slums. London: Verso.

Departamento da Criança e do Adolescente Secretaria de Estado dos Direitos Humanos, Fundo das Nações Unidas para a Infância (1990). ECA - Estatuto da criança e do adolescente: convenção sobre os direitos da criança. Brasília: Ministério da Justiça, 2002.

Departamento de homicídios e de proteção à Pessoa (DHPP) (2005). Anuário 2002-2003. Polícia Civil do Estado de São Paulo, 2005.

Dillon Soares, Sergei Suarez (2007). Educação: um escudo contra o homicídio?. Brasília: Ipea. Texto para discussão N. 1298.

D’oliveira, Carlos Felipe Almeida (2005). Perfil epidemiológico dos Suicídios: Brasil e Regiões, 1996 a 2002. Tentativa suicídio - Brasil 2003. Disponível em: <http://portal.saude.gov.br/portal/arquivos/pdf/Suicidios.pdf> 
Dowdney, Luke (2005). Nem Guerra Nem Paz: comparações internacionais de crianças e jovens em violência armada. Rio de Janeiro: 7Letras.

Duarte, C. A. V. P.; Carlini-Cotrim, B. (2000). Álcool e violência: estudo dos processos de homicídio julgados nos Tribunais do Júri de Curitiba, PR, entre 1995 e 1998. In: Jornal Brasileiro de Dependências Químicas, v. 1, n.1, p.17-25.

Durham, Eunice (1988). A pesquisa antropológica com populações urbanas: problemas e Perspectivas. In: Cardoso, Ruth (org.). 1988. A aventura antropológica: teoria e pesquisa. Rio de Janeiro: Paz e Terra.

Durkheim, Emile (2000). Lições de Sociologia: a moral, o direito e o Estado. São Paulo: Martins Fontes.

Elias, Norbert; Scotson, John L. (2000). Os estabelecidos e os outsiders: sociologia das relações de poder a partir de uma pequena comunidade. Rio de Janeiro: Jorge Zahar Editor.

Elias, Norbert (1939[1993]). O Processo Civilizador. Rio de Janeiro: Zahar. 2 v.

Endo, Paulo César (2005). A Violência no Coração da Cidade: Um Estudo Psicanalítico sobre as violências na cidade de São Paulo. 1. ed. São Paulo: Escuta.

Estrada, Felipe. (2001). Juvenile Violence as a Social Problem. Trends, media attention and societal response. In: British Journal of Criminology, n. 41, p. 639-55, 2001.

Fausto, Boris (2001). Crime e Cotidiano: a criminalidade em São Paulo (1880-1924). 2a ed., São Paulo: Edusp.

Feffermann, Marisa (2006). Vidas Arriscadas: um estudo sobre jovens inscritos no tráfico de drogas. Petrópoles - Rio de Janeiro: Editora Vozes.

Foote, Chris; Goetz, Christopher (2005). Testing Economic Hypotheses with State-Level Data: A Comment on Donohue and Levitt (2001). Federal Reserve Bank of Boston Working Paper 0515, November 22, 2005.

Fórum Brasileiro de Segurança Pública (2007). Anuário do Fórum Brasileiro de Segurança Pública. São Paulo: Fórum Brasileiro de Segurança Pública.

Foucalt, Michel. Microfísica do poder. 1979. Rio de Janeiro: Edições Graal.

Frúgoli JR., Heitor (2005). O urbano em questão na antropologia: interfaces com a sociologia. In: Revista de Antropologia, São Paulo, v. 48, n. 1, p. 133-165, 2005.

Fundação Cide (2006). Anuário Estatístico do Estado do Rio de Janeiro/2006. Rio de Janeiro: Fundação Cide, Secretaria de Planejamento e Integração Governamental, Estado do Rio de Janeiro.

Fundação SEADE (2007). Evolução do Índice de Vulnerabilidade Juvenil 2000-2005. São Paulo: SEADE.

Fundação SEADE (2002). Índice de Vulnerabilidade Juvenil. São Paulo: SEADE.

Garibe, Roberto; Capucci, Paulo (orgs.) (2004) Gestão Local nos territórios da cidade: ciclo de atividades com as subprefeituras. São Paulo: Secretaria Municipal das subprefeituras de São Paulo, Mídia Alternativa Comunicação.

Geertz, Clifford (2001). Nova luz sobre a antropologia. Rio de Janeiro: Jorge Zahar Editor.

Geertz, Clifford (1998[2000]). Fatos e leis em uma perspectiva comparada. In: Geertz, Clifford. 1998[2000]. O saber local. $3^{\text {a }}$ ed., Petrópolis: Editoras Vozes. 
Geertz, Clifford (1989). A interpretação das culturas. Rio de Janeiro: LTC Editora.

Goldman, Márcio (2006). Como funciona a democracia: uma teoria etnográfica da política. Rio de Janeiro: 7Letras.

Goulart, Sandra; Mingardi, Guaracy (2002). Drug Tafficking in an Urban Area: the case of São Paulo. In: Globalisation and drugs criminalization. UNESCO, 2002.

Goulart, Sandra; Mingardi, Guaracy (2001). As Drogas llícitas em São Paulo: o caso da cracolândia. In: Coleção Revista ILANUD, n. 15, p. 07-49, São Paulo, 2001.

Gregori, Maria Filomena (2000). Viração: Experiências de meninos nas ruas. São Paulo: Companhia das Letras.

Gregori, Maria Filomena (1993). Cenas e Queixas - um estudo sobre relações violentas, mulheres e feminismo. São Paulo: Paz e Terra/ANPOCS.

IBGE - Instituto Brasileiro de Geografia e Estatística (2000). Censo Demográfico do IBGE 2000. IBGE.

IBGE - Instituto Brasileiro de Geografia e Estatística (2004). Síntese de Indicadores Sociais 2004. IBGE.

Instituto Cidadania (2004). Perfil da juventude brasileira. São Paulo: Instituto Cidadania.

Instituto de Pesquisa Econômica Aplicada (IPEA) (2002). Mapeamento Nacional Da Situação Do Atendimento Dos Adolescentes Em Cumprimento De Medidas Sócio-educativas. Brasília: IPEA/ Ministério da Justiça.

Instituto Sou da Paz (2005). II Plano Municipal de Diadema. Disponível em: <http://www.soudapaz.org/download/plano_diadema.pdf>.

Kahn, Túlio; Zanetic, André. O Papel dos municípios na redução dos homicídios. SSP/SP, (2006).

Kahn, Túlio; Zanetic, André (2002). Projeto de Avaliação do Espaço Criança Esperança. São Paulo: Ilanud, Instituto Sou da Paz.

Kant de Lima, Roberto (2000). Violência, criminalidade, segurança pública e justiça criminal no Brasil: uma bibliografia. In: BIB - Revista do Boletim Informativo e Bibliográfico em Ciências Sociais, n. 50, v. 2, p. 45-123, Rio de Janeiro, $2^{\mathrm{a}}$ semestre, 2000.

Kant de Lima, Roberto (1995). A polícia da cidade do Rio de Janeiro: seus dilemas e paradoxos. Rio de Janeiro: Editora Forense.

Kant de Lima, Roberto (1989). Cultura Jurídica e práticas policiais: a tradição inquisitorial. In: Revista Brasileira de Ciências Sociais, v. 4, n. 10, São Paulo, p. 65-84, 1989.

Kowarick, Lúcio (2002). Viver em Risco: sobre a vulnerabilidade no Brasil urbano. In: Novos Estudos CEBRAP, n. 63, p. 9-30, São Paulo, 2002.

LABHAB - Laboratório de Habitação e Assentamentos Humanos da FAU/USP (2003). Programa Bairro Legal - relatório final de acompanhamento (Produto P3b). São Paulo: LabHab

Lechner, Norbert (1990). Los patios Interiores de la Democracia. Subjetividad e Política. Chile: Fondo de Cultura Economica. 
Lemgruber, Julia; Musumeci, Leonarda; Cano, Ignácio (2003). Quem vigia os vigias? um estudo sobre controle externo da polícia no Brasil. Rio de Janeiro: Editora Record.

Levi, Giovanni; Schmitt, Jean-Claude (orgs.) (1996). História dos jovens. v. 1, São Paulo: Companhia das Letras.

Levitt, Steven; Dubner, Stephen (2005). Freakonomics: A Rogue Economist Explores the Hidden Side of Everything. New York: HarperCollins Publishers Inc.

Lewis, Oscar (1972). Antropología de la Pobreza: cinco famílias. México: Fondo de Cultura Economica.

Lima, Renato. 2008. Em busca de uma sociologia das estatísticas criminais brasileiras. (No Prelo).

Lima, Renato Sérgio de (2005). Contando Crimes e Criminosos em São Paulo. Uma sociologia das Estatísticas produzidas e utilizadas entre 1871 e 2000. Tese de doutorado defendida no Departamento de Sociologia da USP, São Paulo, 2005.

Lima, Renato Sérgio de (2002). Criminalidade Urbana: Conflitos Sociais e Criminalidade Urbana: uma análise dos homicídios cometidos no Município de São Paulo. São Paulo: Sicurezza.

Lins, Paulo (2001). Cidade de Deus. São Paulo: Companhia das Letras.

Machado da Silva, Luiz Antonio (2004). Sociabilidade violenta: por uma interpretação da criminalidade contemporânea no Brasil urbano. In: Sociedade e Estado. v.19 n.1, Brasília, 2004.

Magnani, José Guilherme Cantor (2006). De trajetos e trajetória: entrevista com José Guilherme Magnani. In: Revista Sexta Feira [Periferia] n. 8. São Paulo: Editora 34.

Magnani, José Guilherme Cantor (2005). Youngsters and their routes in town. In: Tempo social, v. 17, n. 2, São Paulo, 2005.

Magnani, José Guilherme Cantor (2002). De perto e de dentro: notas para uma etnografia urbana. In: Revista Brasileira de Ciências Sociais, v.17, n. 49, p. 11-29, São Paulo, 2002.

Magnani, José Guilherme; Torres, Lillian de Lucca (orgs.) (1996). Na metrópole: textos de antropologia urbana. São Paulo: EDUSP/FAPESP.

Maihara dos Santos, Carolina (2005). Urbanização de favela Parque Novo Santo Amaro. Trabalho de Conclusão de Curso. (Graduação em Arquitetura e Urbanismo) - Faculdade de Arquitetura e Urbanismo da Universidade de São Paulo. Orientador: Antônio Cláudio Moreira Lima e Moreira, 2005.

Malinowski, Bronislaw (2003). Crime e Costume na Sociedade Selvagem. Brasília: Editora da UnB.

Malinowski, Bronislaw (1984). Os Argonautas do Pacífico Ocidental. $3^{\text {a }}$ ed., São Paulo: Coleção Os Pensadores, Abril Cultural.

Marcus, George E.; FISCHER, Michael M. J. (1986). Anthropology as cultural critique: An Experimental Moment in the Human Sciences. Chicago: The University of Chicago Press.

Maricato, Ermínia (2001). Brasil, cidades: alternativas para a crise urbana. Rio de Janeiro: Vozes. 
Maricato, Ermínia (1996). Metrópole na Periferia do Capitalismo: ilegalidade, desigualdade e violência. Faculdade de Arquitetura da USP. (Mimeo)

Marques, Carolina Moreira (1999). A cidadania como metáfora: o projeto de formação $e$ organização de meninos e meninas do movimento nacional de meninos e meninas de rua. São Paulo: Dissertação de Mestrado apresentada ao Departamento de Sociologia USP.

Marques, Eduardo; Torres, Haroldo (2005). São Paulo - segregação, Pobreza e Desigualdades Sociais. São Paulo: Senac São Paulo.

Marques, Eduardo (2005). Elementos conceituais da segregação, da pobreza urbana e da ação do Estado. In: Marques, Eduardo; Torres, Haroldo. 2005. São Paulo - segregação, Pobreza e Desigualdades Sociais. São Paulo: Senac São Paulo.

Martins, José de Souza (2002). A Sociedade Vista do Abismo. Novos Estudos sobre exclusão, pobreza e classes sociais. Petrópolis: Editora Vozes.

Mello Jorge, MHP; Gawryszewski, VP; Latorre, MRDO (1997). Análise dos dados de mortalidade. In: Mello Jorge, MHP; Laurenti, R. 1997. Acidentes e violência no Brasil. Revista de Saúde Pública 31(Supl. 4), p. 5-25.

Mesquita Neto, Paulo de; Alves, Renato (2007). $3^{\circ}$ Relatório Nacional de Direitos Humanos. São Paulo: Universidade de São Paulo, Núcleo de Estudos da Violência.

Mesquita Neto, Paulo de (2006). Políticas municipais de segurança cidadã: problemas e soluções. São Paulo: Fundação Friedrich Ebert, Cadernos Análises e Propostas.

Mesquita Neto, Paulo de (1999). Violência Policial no Brasil: Abordagens Teóricas e Práticas de Controle. In: Chaves Pandolfi, Dulce; Murilo de Carvalho, José; Piquet Carneiro, Leandro; Mario Grynszpan, Mario (orgs.). 1999. Cidadania, Justiça e Violência. Rio de Janeiro: Fundação Getúlio Vargas.

Ministério da Saúde, UNESCO, Ministério da Justiça (2004). Vidas Poupadas. Impacto do Desarmamento no Brasil. Brasília: MS/UNESCO/MJ.

Ministério do Desenvolvimento e Combate à Fome, Secretaria Nacional de Assistência Social (2004). Política Nacional de Assistência Social 2004. Brasília, 2004.

Mintz, Sidney (1984). Encontrando Taso me descobrindo. In: Dados Revista de Ciências Sociais, v. 27, n. 1, p. 45-58, Rio de Janeiro, 1984.

Miraglia, Paula (2006). Os municípios e a Segurança Pública. In: Renato Sérgio de Lima; Liana de Paula (eds.). 2006. Segurança Pública e violência: o Estado está cumprindo o seu papel? São Paulo: Editora Contexto.

Miraglia, Paula (2005). Aprendendo a Lição: uma etnografia das Varas Especiais da Infância e da Juventude. In: Novos Estudos CEBRAP, v. 72, São Paulo, p. 79-98, 2005.

Miraglia, Paula (2001). Rituais da Violência - a Febem com espaço do Medo em São Paulo. Dissertação de Mestrado defendida no Departamento de Antropologia Social da Universidade de São Paulo, 2001.

Misse, Michel (2007). Mercados ilegais, redes de proteção e organização local do crime no Rio de Janeiro. In: Estudos Avançados, v. 21, n. 61, p. 139-157, São Paulo, 2007.

Misse, Michel (1995a). Cinco teses equivocadas sobre a criminalidade urbana no Brasil: uma abordagem crítica, acompanhada de sugestões para uma agenda de pesquisas. In: Série Estudos, n.91. Violência e Participação Política. Rio de Janeiro: IUPERJ.

Morrison, Andrew; Buvinic, Mayra; Orlando, María Beatriz (2002). Violencia, crimen y desarrollo social en América Latina y el Caribe. In: C. Sojo (ed.). 2002. Desarrollo Social en 
América Latina: Temas y Desafíos para las Políticas Públicas. Washington: World Bank and Flacso - Sede Costa Rica.

Moser, Caroline; Mcilwaine, Cathy (2006). Latin American Urban Violence as a development Concern: Towards a Framework for Violence Reduction. In: World Development, v. 34, n.1, p. 89-112, Quebec, 2006.

Moser, Caroline (2004). Urban Violence and Insecurity: An Introductory Roadmap. International Institute for Environment and Development (IIED), SAGE Publications.

Moser, Caroline; Bronkhorst, Bernice van (1999). Youth Violence in Latin America and the Caribbean: Costs, Causes, and Interventions. LCR, Sustainable Development Working Papers.

Muniz, Jacqueline de Oliveira; Zacchi, Jose Marcelo (2005). Avanços, Frustrações e Desafios para uma Política Progressista, Democrática e Efetiva de Segurança Pública no Brasil. In: Santiago Escobar (editor). Seguridad Ciudadana: concepciones y políticas. Caracas: Nueva Sociedad, 2005, 85-147.

Musumeci, Leonarda (1998). Serviços privados de vigilância e guarda no Brasil: um estudo a partir de informações da PNAD - 1985/95. Rio de Janeiro: IPEA. Texto para discussão.

Paes de Barros, Ricardo; Carvalho, Mirela de (2006). Quatro dilemas centrais para a política social brasileira. Brasília: IPEA.

Paes Manso, Bruno (2005a). O Homem X: uma Reportagem Sobre a Alma do Assassino em São Paulo. São Paulo: Record.

Peirano, Mariza (1995). A favor da etnografia. Rio de Janeiro: Editora Relume-Dumará.

Peralva, Angelina (2000). Violência e Democracia: o Paradoxo Brasileiro. São Paulo: Paz e Terra.

Peres, Maria Fernanda Tourinho. (2006). Violência: um problema de Saúde Pública. In: Renato Sérgio de Lima; Liana de Paula. (Org.). 2006. Segurança pública e violência: o Estado está cumprindo o seu papel?. São Paulo: Editora Contexto, p. 101-112.

Phebo, Luciana (2005). Impacto da Arma de Fogo na Saúde da População no Brasil. In: Fernandes, Rubem César e outros. 2005. Brasil: As Armas e as Vítimas. Rio de Janeiro: 7Letras/ISER.

Pinheiro, Paulo Sérgio (2005). World Report on violence against children. The United Nations Secretary General's Study on Violence Against Children, 2005.

Pinheiro, Paulo Sérgio (2001). Transição política e não-estado de direito na República. In:

Rolnik, R. (1997). A Cidade e a Lei - legislação, política urbana e territórios na cidade de São Paulo. São Paulo: Studio Nobel/FAPESP.

Pinheiro, P. S.; Mendez, J.; O'Donnell G. (orgs.) (2000). Democracia, Violência e Injustiça: o não-estado de direito na América Latina. São Paulo: Paz e Terra.

Pinheiro, Paulo Sérgio (1982). Polícia e crise política: o caso das polícias militares. In: Maria Célia Paoli et al. 1982. A Violência Brasileira. São Paulo: Editora Brasiliense, p. 57-92.

Prefeitura do Município de São Paulo (2002). Pobreza e Violência no Município de São Paulo. São Paulo, 2002.

Ramos, Silvia; Paiva, Anabela (2007). Mídia e violência: novas tendências na cobertura de criminalidade e segurança no Brasil. Rio de Janeiro: IUPERJ. 
Revista Sexta Feira (2006). Editorial. In: Revista Sexta Feira [Periferia] n. 8. São Paulo: Editora 34.

Rodgers, Dennis (2003). "Vivemos num estado de sítio": Violência, crime e gangues na Nicarágua pós-conflito. In: Revista Sexta Feira [Guerra] n.7. São Paulo: Editora 34.

Rodgers, Dennis (1999a). Making Danger a Calling: Anthropology, violence and the dilemmas of participant observation. Crises States Programme paper, London School of Economics and Political Science (LSE), 1999.

Rodgers, Dennis (1999b). Youth Gangs and Violence in Latin America and the Caribbean: a Literature Survey. LCR, Sustainable Development Working Paper N. 4, The World Bank, 1999.

Rolnik, Raquel (2002). Exclusão Territorial e Violência, o caso do Estado de São Paulo. Mimeo, 2002.

Rolnik, Raquel (1998). São Paulo, um século de regulação urbanística: para quem? Para quê? . Cadernos IPPUR/UFRJ, Rio de Janeiro, n. 1 e 2, 1998.

Ross, Jurandyr Luciano Sanches; Villela, Fernando Nadal Junqueira (2003). Estudo empírico da fragilidade de um ambiente natural antropizado: 0 bairro do Parque Novo Santo Amaro e seu entorno próximo. In: Simpósio Brasileiro de Geografia Física Aplicada, 10, 2003. Rio de Janeiro: Departamento de Geografia, UERJ.

Sachs, Igancy, Wilheim, Jorge, Pinheiro, Paulo Sérgio (2001). Brasil um século de transformações. São Paulo: Cia. das Letras, p. 260-305.

Sahlins, Marshall (1988). Cosmologias do Capitalismo: O Setor Trans-Pacífico do Sistema Mundial. In: Anais da XVI Reunião Brasileira de Antropologia. Campinas, SP, p. 47-106, 1988.

Sahlins, Marshall (1979). Cultura e Razão Prática. Rio de Janeiro: Zahar Editores.

Said, Edward 1979[2000]. Orientalismo, o Oriente como invenção do Ocidente. São Paulo: Companhia Das Letras.

Scheper-Hughes, Nancy; Bourgois, Philippe (2004). Violence in War and Peace. United Kingdon: Blackwell Publishing.

Schindler, Norbert (1996). Os tutores da desordem: rituais da cultura juvenil nos primórdios da Era Moderna. In: Levi, Giovanni; Schmitt, Jean-Claude (organizadores). 1996. História dos jovens. v. 1. São Paulo: Companhia das Letras.

Schwarcz, Lilia Moritz (2007). Pretos contra brancos ou dando e mudando nomes. In: Cabral, João de Pina; Viegas, Susana de Matos (orgs.) (2007). Gênero, etnicidade e família. Lisboa: Almedina.

Schwartzman, Simon; Reis, Elisa Pereira (2002). Pobreza e Exclusão Social: Aspectos sóciopolíticos. Banco Mundial, paper, 2002.

Sen, Amartya (2000). Desenvolvimento como liberdade. São Paulo: Companhia das Letras.

Seegers, Anthony (1981). Nature and Society in Central Brazil: The Suya Indians of Mato Grosso. Cambridge: Harvard University Press.

Silva, Enid Rocha Andrade; Gueresi, Simone (2003). Adolescente em conflito com a lei: Situação do atendimento institucional no Brasil. Brasília: IPEA. Texto para discussão N. 979. 
Silva, Helena Oliveira da; Silva, Jailson de Souza (2005). Análise da Violência contra a criança e o adolescente segundo o clico de vida no Brasil. São Paulo: UNICEF.

Silva, Jailson de Souza (2005). Até Quando? In: UNICEF (org.). 2005. Direitos negados: a violência contra a Criança e o Adolescente no Brasil. Brasília: UNICEF.

Singer, Paul W. (2003). Corporate Warriors. The rise of the Privatized Military Industry. Ithaca and London: Cornell University Press.

Soares, Luiz Eduardo; Guindani, Mirian (2007). A Violência do Estado e da Sociedade no Brasil Contemporâneo. In: Nueva Sociedad, n. 208, Marzo-Abril, 2007.

Soares, Luiz Eduardo (2006). Segurança pública: presente e futuro. In: Revista Estudos Avançados, v. 20, n. 56, p. 91-106, São Paulo, 2006.

Soares, Luiz Eduardo; Bill, MV; Athayde, Celso (2005). Cabeça de Porco. Rio de Janeiro: Objetiva.

Soares, Luiz Eduardo (2000). Meu casaco de general: quinhentos dias no front da Segurança Pública do Rio de Janeiro. São Paulo: Companhia das Letras.

Soares, Luiz Eduardo (1996). Violência e política no Rio de Janeiro. Rio de Janeiro: Editora Relume-Dumará/ISER.

Spangnol, Antonio Sergio (2002). Garotos Perdidos. Um estudo sobre os Jovens Delinqüentes na Cidade de São Paulo. Tese de Doutorado, Universidade de São Paulo, Departamento de Sociologia, 2002.

Sposati, Aldaíza (coord.) (1996). Mapa da Exclusão/Inclusão Social da Cidade de São Paulo. São Paulo: Educ.

Sposato, Karyna Batista (2006). O direito penal juvenil. São Paulo: Editora Revista dos Tribunais.

Taussig, Michael (1993). Xamanismo, Colonialismo e o Homem Selvagem: um estudo sobre o terror e a cura. Rio de Janeiro: Editora Paz e Terra.

Taussig, Michael (1992). Terror as usual: Walter Benjamin's theory of history as state of siege. In: Scheper-Huges, Nancy; Bourgois, Philippe (edits.). 2004. Violence in war and peace: an anthology. UK: Blackwell Publishing.

Tavares dos Santos, José Vicente (2004). Violências e dilemas do controle social nas sociedades da "modernidade tardia". In: São Paulo em Perspectiva, v. 18, n. 01, São Paulo, p. 3-12, 2004.

Tavares dos Santos, José Vicente (2002). A violência na escola, uma questão social global. In: Briceño-León, R. 2002. Violência, Sociedad y Justicia en America Latina. Buenos Aires: CLACSO.

Tavares dos Santos, José Vicente (1999). Novos processos sociais globais e violência. In: São Paulo em Perspectiva, v. 13, n. 03, São Paulo, p.18-23, 1999.

Thrasher, Frederic (1936). The gang: A Study of 1313 Gangs in Chicago. Chicago: University of Chicago Press.

Toledo, Luiz Henrique de (2001). Futebol e teoria social: aspectos da produção científica brasileira (1982-2002). In: BIB, 52, São Paulo, p. 133-166.

Toledo, Luiz Henrique (1996). Torcidas organizadas de futebol. Campinas: Autores Associados/Anpocs. 
Tsing, Anna. 2005. Friction: an ethnography of global connection. New Jersey: Princeton University Press.

Velho, Gilberto; Kuschinir, Karina (orgs.) (2003). Pesquisas urbanas: desafios do trabalho antropológico. Rio de Janeiro: Jorge Zahar.

Velho, Gilberto (2000). Violência, reciprocidade e desigualdade: uma perspectiva antropológica. In: VELHO, Gilberto; ALVITO, Marcos (organizadores). 2000. Cidadania e violência no Rio de Janeiro. $2^{\text {a }}$ ed., Rio de Janeiro: Editora da UFRJ/FGV.

Velho, Gilberto (1980). O Desafio da Cidade: novas perspectivas da Antropologia Brasileira. Rio de Janeiro: Editora Campus.

Vilhena Vieira, Oscar (1996). Estado de Direto, seus Limites e a Criminalidade. In: Revista Brasileira de Ciências Sociais, n. 14, p. 201-214, São Paulo, 1996.

Viveiros de Castro, Eduardo (2002). O nativo Relativo. In: Mana Estudos de Antropologia Social v.8, n.1, p. 113-148, Rio de Janeiro, 2002.

Wacquant, Loïc (2004). A Aberração Carcerária à Moda Francesa. In: DADOS - Revista de Ciências Sociais, v. 47, n. 2, p. 215 - 232, Rio de Janeiro, 2004.

Wacquant, Loïc (2001). Prisões da miséria

Waiselfisz, Julio Jacobo; Athias, Gabriela (2005). Mapa da Violência de São Paulo. Brasília: UNESCO.

Waiselfisz, Julio Jacobo (2005). Mortes matadas por armas de fogo no Brasil - 1979/2003. Brasília: UNESCO.

Waiselfisz, Julio Jacobo (2004a). Mapa da violência IV: os jovens do Brasil. Brasília:

UNESCO, Instituto Ayrton Senna, Ministério da Justiça, Secretaria Estadual de Direitos Humanos (editors).

Waiselfisz, Julio Jacobo (org.) (2004b). Relatório de desenvolvimento Juvenil 2003. Brasília: UNESCO.

Waiselfisz, Julio Jacobo (2002). Mapa da Violência III: Os Jovens do Brasil. Brasília: UNESCO, Instituto Ayrton Senna, Ministério da Justiça, Secretaria Estadual de Direitos Humanos.

Weber, Max (1998). Ciência e Política. Duas Vocações. São Paulo: Editora Cultrix.

Zaluar, Alba (2000). Redes de tráfico e estilos de consumo de drogas ilegais. Relatório final de Pesquisa, IMS - NUPEVI, Universidade do Estado do Rio de Janeiro, 2000.

Zaluar, Alba (1999). Violência e Crime. In: Miceli, Sérgio (org.). 1999. O que ler na ciência social brasileira. São Paulo: Editora Sumaré, ANPOCS.

Zaluar, Alba (1998). Pra não dizer que não falei de samba: os enigmas da violência no Brasil. In: Schwarcz, Lilia Moritz (org.). 1998. História da vida privada no Brasil: contrastes da intimidade contemporânea. v. 4. São Paulo: Companhia das Letras.

Zaluar, Alba (1997). Gangues, Galeras, e Quadrilhas: globalização, juventude e violência. In: Vianna, Herman. 1997. Galeras Cariocas. Rio de Janeiro: Editora UFRJ.

Zaluar, Alba (1994a). Cidadãos não vão ao paraíso. Campinas: Editora da Unicamp.

Zaluar, Alba (1994b). Exclusão Social e Violência. In: Zaluar, Alba. 1994. Cidadãos não vão ao paraíso. Campinas: Editora da Unicamp, 
Zaluar, Alba (1994c). Condomínio do diabo. Rio de Janeiro: Editora da UFRJ.

Zaluar, Alba (1988). Teoria e prática do trabalho de campo: alguns problemas. In: CARDoso, Ruth (org.). 1988. A aventura antropológica: teoria e pesquisa. Rio de Janeiro: Paz e Terra.

Zanetic, André (2005). A questão da Segurança Privada: Estudo do marco regulatório dos serviços particulares de segurança. Dissertação de Mestrado defendida no Departamento de Ciência Política da Universidade de São Paulo, 2005.

Zimring, Franklin (1998). Toward a Jurisprudence of Youth Violence. In: M. Tonry; M. Moore (eds.). 1998. Crime and Justice: A Review of Research, vol. 24, Youth Violence. Chicago/London: The University of Chicago Press, p. 477-501.

\section{Artigos de Jornais}

Cabral, Sergio (2007). Cotidiano. In: Folha de São Paulo, 13.02.2007.

Cabral, Sergio (2007). Cotidiano. In: Folha de São Paulo, 25.10.2007.

Dimenstein, Gilberto (2007). In: Folha de São Paulo, 11.08.2007.

Hartung, Gabriel (2007). Tendências e Debates. In: Folha de São Paulo, 27.10.2007.

Khan, Túlio (2007). Na "encenação", o sangue é de verdade. In: Tendências e Debates, Folha de São Paulo, 14.02.07.

Marques, Eduardo (2006). Os dois lados da segregação. In: Caderno Aliás, O Estado de São Paulo, 21.05.2006.

Martine, George; Correia, Sonia (2007). Os perigos da simplicidade. In: Tendências e Debates, $\begin{array}{llll}\text { Folha de } & \text { São } & \text { Paulo, } & \text { 2007. }\end{array}$

Mesquita Neto, Paulo de (2007). Falta transparência na segurança pública. In: Tendências e Debates, Folha de São Paulo, 07.02.2007.

Miraglia, Paula; Sposato, Karina (2007). Mudar a lei não muda a realidade. In: Tendências e Debates, Folha de São Paulo, 17.02.2007.

Moreira Salles, João (2006). Entrevista Caderno Mais! In: Folha de São Paulo, 26.03.2006.

Oliveira, Adriano; Zaverucha, Jorge (2007). As milícias e a falta de Estado. In: Tendências e Debates, Folha de São Paulo, 16.01.2007.

Paes Manso, Bruno (2005b). In: O Estado de São Paulo, 27.10.2005.

Vanucchi, Paulo (2006). In: O Globo, 20.3.2006.

\section{Documentos de Organismos Internacionais}

Commission on Human Security (2003). Human Security now: Protecting and empowering people. New York: Commission on Human Security.

General Assembly Economic and Social Council (2005). World Youth Report 2005. United Nations, 2005.

Lamas, Jorge; Alda, Erik; Muvinic, Mayra (2005). Emphasizing Prevention. In: Citizen Security: the Inter-American Development Bank's contribution to reducing violence in Latin America 
and the Caribbean. Washington D.C: Sustainable Development Department, Best Practices Series, 2005.

UN-Habitat - United Nations Human Security Settlements Programme (2007). Global Report on Human Settlements 2007.London: UN-Habitat, Earthscan.

World Bank (1990). World Development Report 1990: Poverty. New York: Oxford University Press.

World Bank (1999). Sustainable Development Working Paper No. 3. Urban Peace Program Series, 1999.

World Health Organization (WHO) (2004). The economic dimensions of interpersonal violence. Geneva: WHO.

World Health Organization (WHO) (2002a). Guide to United Nations Resources and activities for prevention of interpersonal violence. Geneva: Injuries and Violence Prevention department - WHO.

World Health Organization (WHO) (2002b). World report on violence and health. Geneva: WHO.

United Nations Congress on Crime Prevention and Criminal Justice (2005). Strategies and Best practices for crime prevention in particular in relation to Urban Areas and Youth at risk. Bangkok: Workshop 3.

\section{Sites consultados}

'Organismos Governamentais

Departamento Penitenciário Nacional (DEPEN)

http://www.mj.gov.br/depen

Fundação Sistema Estadual de Análise de Dados (SEADE)

http://www.seade.gov.br

Instituto Brasileiro de Geografia e Estatística (IBGE)

www.ibge.gov.br

Ministério da Justiça (MJ)

http://www.mj.gov.br

Secretaria Especial de Direitos Humanos (SEDH)

http://www.presidencia.gov.br/sedh

Secretaria Nacional de Segurança Pública (SENASP)

http://www.mj.gov.br/senasp 
'Organismos não governamentais

Associação Brasileira de Estudos Populacionais (ABEP)

http://br.groups.yahoo.com/group/PopPobrezaABEP

Comunidade Segura

http: //www.comunidadesegura.org

Escritório das Nações Unidas contra Drogas e Crime (UNODC-Brasil)

http: //www.unodc.org/brazil

Fórum Brasileiro de Segurança Pública (FBSP)

http://www. forumseguranca.org.br

\section{ILANUD}

http://www.ilanud.org.br

Instituto Sou da Paz

http: / / www.soudapaz.org.br

Núcleo de Estudos da Violência/Universidade de São Paulo (NEV/USP)

www. nevusp.org

Segurança Cidadã

http://www.segurancacidada.org.br 
ANEXOS 